\begin{abstract}
UNIVERSIDADE DE SÃO PAULO
FACULDADE DE FILOSOFIA, LETRAS E CIÊNCIAS HUMANAS

DEPARTAMENTO DE LETRAS CLÁSSICAS E VERNÁCULAS PROGRAMA DE PÓS-GRADUAÇÃO EM LETRAS CLÁSSICAS
\end{abstract}

GILSON CHARLES DOS SANTOS

Arte, imitação e exercício nas Epistulae ad Caesarem (Versão revisada) 


\section{Arte, imitação e exercício nas Epistulae ad Caesarem}

(Versão revisada)

\section{Gilson Charles dos Santos}

Tese apresentada ao Programa de Pós-Graduação em Letras Clássicas, do Departamento de Letras Clássicas e Vernáculas da Faculdade de Filosofia, Letras e Ciências Humanas, para obtenção do título de Doutor em Letras.

Orientador: Prof. Dr. Breno Battistin Sebastiani 
Autorizo a reprodução e divulgação total ou parcial deste trabalho, por qualquer meio convencional ou eletrônico, para fins de estudo e pesquisa, desde que citada a fonte. 


\title{
Resumo
}

Ao elencar as virtudes do príncipe e orientá-lo moralmente a agir em benefício de todos, as Epistulae ad Caesarem são fiéis aos princípios que caracterizam o orador como uir bonus dicendi peritus. Entretanto, a verossimilhança dada à matéria, no que se refere ao perigo de uma guerra civil, contribuiu para a negação de sua artificialidade. A análise feita neste trabalho conduzirá uma discussão acerca das razões “didáticas” para exortar um imperador a debelar o conflito civil, de um lado, e apresentar uma definição de gênero para esses documentos, de outro. Com isso, pretende demonstrar como elas configuram uma imagem da eloquência deliberativa semelhante à verdade, compostas em linguagem ornada a fim de deleitar uma audiência. Dessa forma, mostram tanto uma educação oratória adequada quanto um estudo diligente das virtudes do homem público.

Palavras-chave:

Declamação; Epistolografia; Prosopopeia; Retórica; Literatura latina.

\begin{abstract}
By enumerating the virtues of the prince and guiding him morally on how to act for the benefit of the whole community, the Epistulae ad Caesarem are faithful to the principles that characterize the orator as uir bonus dicendi peritus. However, the verisimilitude of treatment given to the subject, regarding the danger of civil wars, contributed to deny their artificiality. On the one hand, the analysis in this work will lead a discussion about the "educational” motivations for urging an emperor to quell civil strife, and on the other hand it will present a definition of these documents' gender. It intends to demonstrate how they are figurated as an image of deliberative eloquence similar to the truth, written in an embellished language in order to delight an audience. Therefore, not only do they demonstrate the adequate education of the orator but also a diligent study of virtues of the statesman.
\end{abstract}

Key-words:

Declamation; Epistolography; Prosopopoeia; Rhetoric; Latin Literature. 


\section{Agradecimentos}

Ao Prof. Dr. Breno Battistin Sebastiani pelo interesse e pela zelosa orientação, pelo apoio e pela solicitude incondicionais ao longo de todo o doutorado, para não dizer desde minha defesa de mestrado.

Ao Prof. Dr. João Ângelo Oliva Neto, pela prestatividade e prontidão generosamente demonstradas ao aceitar a orientação desta tese nos seus primeiros, indecisos e tímidos passos.

À Profa. Dra. Ana Thereza Basilio Vieira, ao Prof. Dr. Fábio Duarte Joly, ao Prof. Dr. José Eduardo dos Santos Lohner e ao Prof. Dr. Pablo Schwartz Friedman, membros da banca de defesa, aos quais não apenas devo agradecimento sincero pelas observações realizadas no exame, como ainda pela contribuição que me deram ao estabelecer os limites e as questões que eu teria condições de responder neste trabalho.

À Profa. Dra. Elaine Sartorelli, minha primeira professora de Latim e a quem devo a descoberta horaciana de que há, de fato, muito mais entre o céu e a terra do que sonha nossa vã filosofia.

Ao coordenador do curso de Latim do Centro de Línguas da FFLCH-USP, Prof. Dr. Robson Tadeu Cesila, e aos funcionários e monitores da referida instituição.

Aos meus alunos de Latim no Centro de Línguas da FFLCH-USP, especialmente Áureo Castanho, Karla Neves, Maria José de Araújo, Viviane Kawata e Vinícius Marino.

Ao Prof. Dr. Martin Dinter e ao Prof. Dr. Michael Dewar, graças aos quais uma nova etapa da minha vida acadêmica poderá começar, desta vez noutras terras.

Aos amigos Dijalma Madeira Cândido, Thiago Humberto do Nascimento, Karen Kipnis, Artur Costrino, Roney Costa, Adriana Domenico, Adrian M. Olivera Rojas, Maria Cecília Oliva, Bia Szvat, Tânia Aiko Aragute, Kevin Balston, Daniel Pecchio, Lucas Vitti Rodrigues, Tina Montenegro, Rosangela S. Souza Amato, por me mostrarem que a vida pode ser sempre melhor.

Ao meu irmão Danilo, que me ajudou nas lides com o computador, à minha irmã, Fabiana, ao meu pai, Francisco, e à minha mãe, Rita, sem os quais não poderia existir e ser quem sou. 
Para Maria Júlia dos Santos Treza Rodrigues 


\section{Sumário}

Introdução.

Definição de prosopopeia ............................................................................................ 13

Definição de epístola .......................................................................................................... 17

Parte I - Arte, imitação e exercício nas Epistulae ad Caesarem ................................................. 23

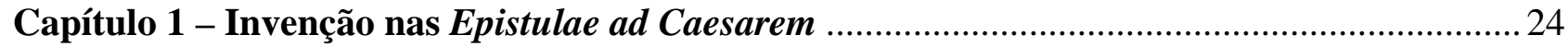

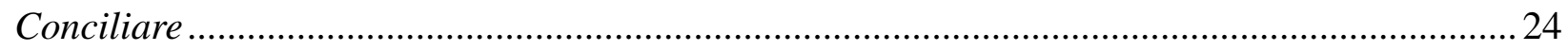

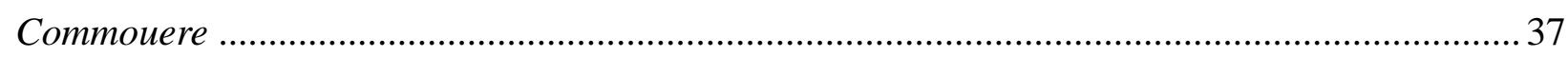

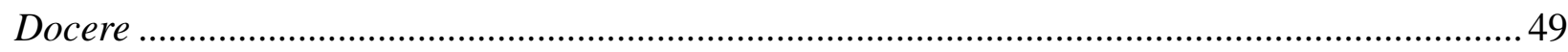

Capítulo 2 - Disposição e elocução nas Epistulae ad Caesarem ................................................ 94

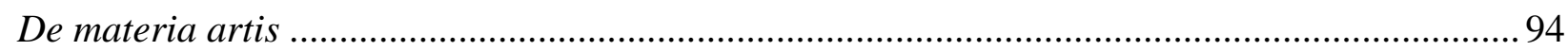

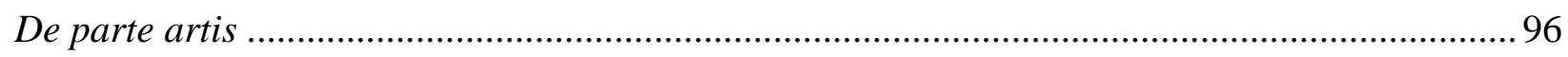

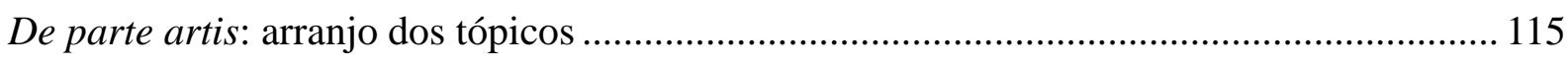

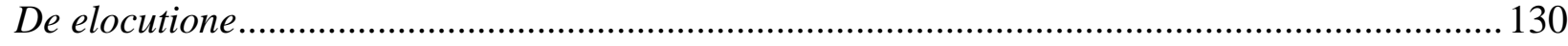

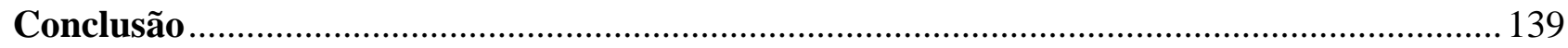

Parte II - Texto original e tradução das Epistulae ad Caesarem ........................................... 152

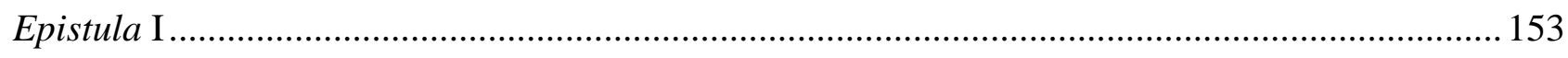

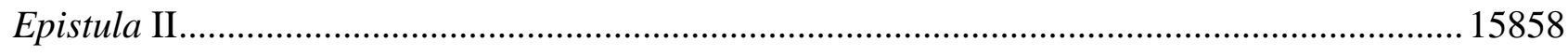

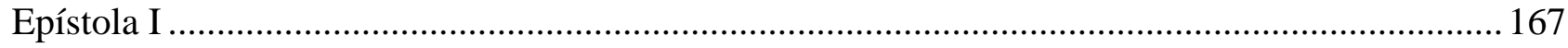

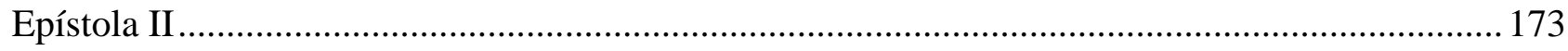

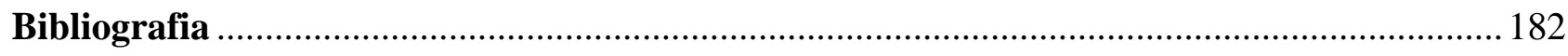

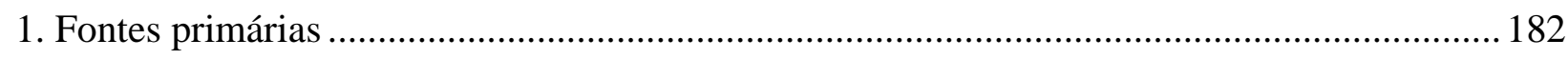

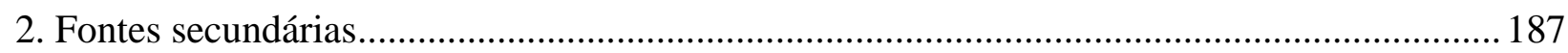




\section{Introdução}

Seria quase certo afirmar que as Epistulae ad Caesarem (doravante Ep. ad Caes.) constituem um dos poucos exemplos de texto escolar produzido na antiguidade que chegou íntegro aos nossos dias, não fosse seu complicado histórico de transmissão e o fato de que as pesquisas no campo da história da educação - ainda que concentradas na relação indivíduo/sociedade, nos diferentes métodos pedagógicos ou na estruturação das áreas do saber - nunca as tomaram devidamente como objeto de atenção.

Diminuindo, porém, o impacto desse último aspecto, pesam as descobertas de papiros egípcios com exercícios de alfabetização nas línguas grega e latina (Morgan, 1998, pp. XVI-XVII) que, se não registram textos iguais ao objeto desta tese, pelo menos documentam a pouca variação dos exercícios escolares no tempo e no espaço, o papel fundamental do letramento como assimilação da cultura grega ou latina nas regiões mais distantes dos centros administrativos e, finalmente, as etapas que levam o indivíduo desde os conhecimentos rudimentares da língua grega ou latina até à compreensão e imitação daqueles autores que as letras consagravam como modelares (Morgan, 1998, pp. 3-33).

A essas etapas, que encerram a aquisição de conhecimentos de gramática, literatura, geometria, astronomia, música e lógica (Morgan, 1998, p. 35), Quintiliano (Inst. Or. I 10,1) chama orbis doctrinae, tradução do grego enkyklios paideia, termo que posteriormente se confundiu com um vocabulário muito vasto e impreciso para nomear aquilo que chamaríamos hoje "educação formal” (Morgan, id. ibid.): institutio, educatio, studia, liberalia studia, principia, cura docendi, praecipienda, litterae, litteratura, artes, sendo esse último termo o mais adotado nas fontes antigas sobre o assunto ${ }^{1}$.

1 cf. com a definição de Vitrúvio (I 1.12) Ac fortasse mirum videbitur inperitis hominibus posse naturam tantum 
Quanto à aquisição das normas de expressão, o processo de alfabetização compreendia duas fases distintas: uma primeira, que cabia ao grammaticus - o responsável pelo aprendizado das normas de expressão - e uma segunda, que cabia ao rhetor - o responsável pelo domínio da oratória. Entretanto, o limite da atuação do grammaticus e do rhetor não era especialmente definido, a considerar a crítica de Quintiliano (Inst. Or. II 1,4-6) em relação à aplicação dos exercícios de formação do orador (progymnasmata, praeexercitamina), p. ex. a suasória (Inst. Or. II 1,2), os quais, a despeito do nível de dificuldade, eram de tal maneira apresentados pelo grammaticus, que quase dispensavam o trabalho do rhetor. Isso se deve à natureza contígua do ofício de um e de outro $^{2}$, à intervenção do grammaticus na docência de partes elementares do discurso e à preocupação quase exclusiva do rhetor com a performance.

Baseando-se nos três gêneros aristotélicos (Rhet. 1, 3 1358b) - deliberativo, judiciário e demonstrativo - a retórica escolar agrupou os discursos conforme uma teoria do tema ou da matéria (questão situacional, credibilidade do orador) e conforme uma teoria da elaboração ou preparação do discurso (invenção, disposição, elocução, memória e performance) (Lausberg, 1994, §§ 20-45). É para essa última que servem os praeexercitamina, que chegaram a nós em cinco tratados (em língua grega) e em outras duas obras (em língua latina). Escritos (ou atribuídos), respectivamente, a Teão, Hermógenes, Libânio, Aftônio, Nicolau e Prisciano, esses textos reuniam, em formato curricular, cerca de quatorze exercícios que, se variavam em número, nome, divisão e sequência, não variaram muito quanto ao uso, no tempo e no espaço, desde o período helenístico até à Idade Média (Morgan, 1998, pp. 3-33).

A tabela seguinte (Kennedy, 2003, p. xiii adap.) apresenta a ordem desses exercícios conforme os quatro maiores tratados de progymnasmata em língua grega, acrescida da menção à tradução latina do tratado de Hermógenes, feita por Prisciano:

numerum doctrinarum perdiscere et memoria continere. Cum autem animadverterint omnes disciplinas inter se coniunctionem rerum et communicationem habere, fieri posse faciliter credent; encyclios enim disciplina uti corpus unum ex his membris est composita. Itaque qui a teneris aetatibus eruditionibus variis instruuntur, omnibus litteris agnoscunt easdem notas communicationemque omnium disciplinarum, et ea re facilius omnia cognoscunt.

2 A correção linguística (puritas) não é adereço do discurso e sim requisito, a par das duas demais uirtutes elocutionis - a perspicuitas e o ornatus (cf. Lausberg, 1994, § 460). 


\begin{tabular}{|c|c|c|c|c|}
\hline Exercício & Teão & $\begin{array}{c}\text { Hermógenes, } \\
\text { Prisciano }\end{array}$ & Aftônio & $\begin{array}{c}\text { Nicolau, o } \\
\text { Sofista }\end{array}$ \\
\hline Mythos, fabula & 2 & 1 & 1 & 1 \\
\hline Diêgêma, diêgêsis, narratio & 3 & 2 & 2 & 2 \\
\hline Khreia, usus & 1 & 3 & 3 & 3 \\
\hline Gnômê, sententia & 1 & 4 & 4 & 4 \\
\hline Anaskeuê, refutatio & 3 & 5 & 5 & 5 \\
\hline Kataskeuê, confirmatio & 3 & 5 & 6 & 5 \\
\hline Tópos, Koinos topos, locus communis & 4 & 6 & 7 & 6 \\
\hline Enkômion, laus & 7 & 7 & 8 & 7 \\
\hline Psogos & 7 & Não há & 9 & 7 \\
\hline Synkrisis, comparatio & 8 & 8 & 10 & 8 \\
\hline Ethopoeia, prôsopopoeia, allocutio & 6 & 9 & 11 & 9 \\
\hline Ekphrasis, descriptio & 5 & 10 & 12 & 10 \\
\hline Thesis, positio & 9 & 11 & 13 & 11 \\
\hline Nomos, legislatio & 10 & 12 & 14 & 12 \\
\hline
\end{tabular}

Em geral, os praeexercitamina tratavam separadamente de pequenos elementos do discurso a fim de preparar o aluno para a produção de textos próprios - orais ou escritos - numa variedade que inclui poesia épica, dramática, “lírica”, discursos judiciais e historiografia.

Esta tese pretende descrever as Ep. ad Caes. como um dos exercícios de formação do orador através da análise dos itens de sua elaboração (invenção, disposição e elocução). Essas epístolas constam originalmente de apenas um manuscrito, o Vaticanus latinus 3864, datado do século IX ou X, e aparecem como apêndice de outros textos de Salústio, de César e de Plínio, o Jovem³ ${ }^{3}$ Ocupam os fólios 127r-133v desse exemplar e receberam alterações de, pelo menos, três copistas, os quais

3 Sobre as condições do manuscrito, q.v. Virgilio Paladini in C. Sallustio. Epistulae ad Caesarem, 1968, prefácio. 
revisaram o texto distintamente até meados do século $\mathrm{XV}$, quando as epístolas foram impressas como obras integrantes da produção do historiador nas duas editiones principes de Salústio, a de 1475, dita Romana, e a de 1476-78, dita Mantuana.

Tal histórico de transmissão foi responsável por aquilo que creio ser um equívoco não desfeito inteiramente até agora. Reunidas às obras de Salústio, por séculos as Ep. ad Caes. foram tidas como produção do historiador, muito embora chamem a atenção pelas discordâncias que apresentam quando comparadas às demais obras de Salústio. Um debate sobre a autenticidade das Ep. ad Caes. foi aberto em 1537, com Sebastiano Corrado, e prolongado desde Justo Lípsio e Carrion (séc. XVII) até Marc Chouet (1950) e Ronald Syme (1959), os quais, em geral, procuravam identificar elementos que justificassem a (in-)autenticidade das Ep. ad Caes. a partir do estudo do vocabulário, da biografia do historiador e de elementos e citações de Salústio e de outros historiadores gregos ou latinos.

A favor da autoria salustiana, por exemplo, Lily Ross Taylor (1949, p. 1; 20; 47) refere-se à acepção da palavra factio e à disputa entre populares e optimates como sendo idênticas nas Ep. ad Caes. e nas monografias de Salústio; além disso, propõe que as epístolas tenham sido produzidas entre os anos 51-46 a.C. a partir da menção à passagem Ep. ad Caes. II 5,7 (Ceterum additis nouis ciuibus magna me spes tenet fore ut omnes expergiscantur ad libertatem, “Ademais, acrescidos de novos cidadãos, toma-me uma grande esperança de haverem outros que despertem para a liberdade”), graças à qual propõe que o aumento do número de cidadãos para diminuir o poder da nobreza teria feito parte das preocupações de César pelo menos até 49 a.C., quando a região da Transpadana recebeu a cidadania graças à ação indireta do general.

Caso exemplar do tipo de análise das Ep. ad Caes. durante o século XX é o estabelecimento do texto e a atribuição do autor nas edições francesa e italiana de Salústio. De um lado, Virgílio Paladini (1968, p.12) faz remontar ao século I ou II d.C. a existência de excerpta salustianos, que gerariam, recta uia, aquele Vaticanus latinus 3864. Seguindo Marc Chouet (cuja tese, intitulada Les Lettres de Salluste à César, publicada pela Société d’Édition “Les Belles Lettres” em 1950, é 
favorável à autoria salustiana dessas cartas), Paladini destaca passagens e expressões frequentes em Salústio, tais como socordia (indolência), em I 5.5, recorrente dezesseis vezes nos escritos do historiador, bem como a construção non...neque...sed, tal como ocorre em I 4.1. Não obstante as diferenças entre os gêneros epistolográfico e historiográfico, o mesmo filólogo, em suas notas à edição das Ep. ad Caes. (1968, pp. 69 et seq.) verifica, entretanto, que, em I 1.1, a expressão per libidinem não teria sido registrada em nenhuma outra passagem salustiana; no entanto, foi verificado o uso de ex libidine em Bel. Cat. 8, 1; Bel. Iug. 60, 5; 62, 4; 54,5 e nas Hist. I 77.17, atestando a frequência dessa expressão em detrimento daquela. Em Ep. ad Caes. I 1.3 o uso de quam junto a um adjetivo (magna), no período ceterum ut fabricata, sic uirtute parta quam magna industria haberei decet [...], seria desconhecido de Salústio. Em Ep. ad Caes. I 1.5 no período id eo evenit, quia plerique rerum potentes peruorse consulunt o advérbio peruorse também não encontraria registro em outras obras de Salústio. Já o período Ep. ad Caes. I 1.6 pessumus quisque asperrume rectorem patitur, remeteria a Sêneca, De ira III 36.4 pessimus quisque rectorem asperrime patitur. No período Ep. ad Caes. I 3.1 hoc uti ciuiliter deponas, illa < ut> quam iustissima os pronomes hoc... illa teriam sido usados invertidamente, o que constituiria traço de um latim ignorado nos tempos de Salústio. Assim também Ernout (1962, p. 14 et seq.) leva em conta os arcaísmos correntes até o período imperial (quom, pleps, uolgi, apsoluei, haut, aduorsum) que não faziam parte do léxico arcaizante procurado por Salústio em suas monografias históricas. Entretanto, e também ignorando as diferenças entre os gêneros epistolográfico e historiográfico, esse filólogo recolheu, nas Ep. ad Caes., passagens que se remetiam àquelas monografias, em especial A Conjuração de Catilina, saída a público após a morte de seu autor ${ }^{4}$.

Ronald Syme opõe-se à autenticidade das Ep. ad Caes. considerando a elocução e, sobretudo, conceitos anacrônicos apresentados nas epístolas. Alegando a curiosidade dos historiadores do século XIX e início do século XX pela vida de Salústio antes da publicação de suas monografias (1959, p. 314; 318), Syme rejeita a leitura biográfica dessas epístolas e conclui que

4 Assim, Cat. 6. 3 = Ep. ad Caes. II 1.3.; também Iug. 2. 3 = Ep. ad Caes. I 5.2. 
elas aproveitam os textos de Salústio pecando, porém, contra o vocabulário político de fins da república; portanto, elas apresentariam propostas que um homem público, nos anos 50 a.C., jamais poderia fazer. Para chegar a essa conclusão, Syme ressalta (1959, pp. 341-347):

a) a inadequação da leitura feita das leis aprovadas por Caio Graco: Ep. ad Caes. II 8,1 (Sed de magistratibus creandis haud mihi quidem absurde placet lex, quam Caius Gracchus in tribunatu promulgauerat; ut ex confusis quinque classibus sorte centuriae uocarentur; “Mas para a eleição dos magistrados e para mim, de fato, agrada muitíssimo a lei, que C. Graco promulgara como tribuno, para serem convocadas ao acaso as centúrias, dentre as cinco classes indistintas”). Apiano (Bel. Civ. I 35,158) não relaciona essas leis ao aumento de magistrados, como a epístola sugere;

b) a menção às figuras históricas de Favônio e Postúmio (Ep. ad Caes. II 9, 4 L. Postumii M. Fauonii mihi uidentur quasi magnae nauis superuacua onera esse; “As adições - L. Postúmio e M. Favônio - parecem-me como a carga inútil de um grande navio”) entre os inertissumi nobiles é equivocada, considerando o fato de que Favônio não era romano e, portanto, não figurava entre os nobiles. A epístola teria imitado Cícero (Ad Att. VII 15,2), que menciona as duas figuras juntas em uma carta;

c) a proposta de voto aberto em relação aos procedimentos do senado (Ep. ad Caes. II 11, 5 Tabella obtentui erit, quo magis animo libero facere audeat: in multitudine et praesidii plus et usus amplior est; “O voto secreto servirá de pretexto para que eles se exponham com o ânimo mais livre”) nega a dignitas senatorial tal como essa virtude era entendida nos tempos de Salústio; registram-se as primeiras tentativas de uso de votação secreta no governo de Trajano, sem grande sucesso; 
d) o uso do termo imperator desacompanhado do nome daquele que recebe o comando militar (Ep. ad Caes. I 2.2; II 12.1; 12.5), designando alguém de poder superior ao emissor da epístola numa situação em que o conflito civil já teria acabado não é praxe republicana, e sim imperial.

Syme (1959, p. 318) afirma que as duas epístolas são suasórias, mas não se ocupa em descrevê-las e devota-se mais em analisar a segunda epístola - a mais frágil em termos de exatidão das informações - do que em formular uma interpretação dos dois documentos ${ }^{5}$. Parto do mesmo princípio de Syme; porém, dado o assunto e a forma das Ep. ad Caes., a hipótese verificada nesta tese é a de que as duas suasórias utilizam o expediente da prosopopeia, aproveitando-se da imitação de Salústio como meio para aprimorar o estilo . O critério metodológico adotado foi a análise da imitação de Salústio em cada parte do discurso conforme disposta nas Ep. ad Caes. Para tanto, retomei o binômio res e uerba tal como, definindo o discurso, repartem-se nos officia oratoris - a inuentio afeta a res; a elocutio, as uerba e a dispositio, a ambas (Lausberg, 1976, § 454).

$\mathrm{Na}$ análise da inuentio, objeto de estudo do primeiro capítulo desta tese, ocupo-me especialmente da composição dos dois documentos a partir da definição das partes da invenção dada por Cícero , que adapta para o latim a terminologia aristotélica (Rhet. 1356a 1-33), mas altera a ênfase dada a ela. Assim, enquanto Aristóteles divide as provas da persuasão fornecidas pelo discurso naquelas que residem no caráter do orador (éthos), naquelas pelas quais o público se predispõe à persuasão (páthos) e, enfim, naquelas que o discurso demonstra ou procura demonstrar (lógos), Cícero muda o foco do éthos aristotélico para manejar as reações do auditório, quando

5 Syme busca as coincidências entre as duas epístolas, mas relaciona especialmente a segunda epístola a outro documento atribuído a Salústio, a Invectiva contra Cícero (In Ciceronem). Entretanto, em razão do gênero, abordarei apenas as Ep. ad Caes.

6 Teão, Prog. 115.11.8, que na definição da prosopopeia inclui neste tipo de exercício a espécie dos discursos de consolação, dos discursos exortativos e dos epistolares; cp. Demétrio, De eloc. 227, segundo o qual a epístola prestase a demonstrar o éthos de seu autor.

7 De Or. II 28, 121 Qua re illam partem superiorem, quoniam semel ita vobis placuit, non recusabo quo minus perpoliam atque conficiam - quantum consequar, vos iudicabitis - quibus ex locis ad eas tris res, quae ad fidem faciendam solae valent, ducatur oratio, ut et concilientur animi et doceantur et moveantur. 
Aristóteles insistia, essencialmente, na credibilidade obtida pelo orador no momento em que esse falava. Na mudança de foco, Cícero inclui a reputação do orador ou a impressão que ele causa na audiência. Por isso, Cícero diferencia três expedientes para estabelecer a credibilidade do discurso, a saber, conciliare (cativar), mouere (influenciar) e docere (instruir). Ademais, para cada um deles, Cícero estabelece um método oratório, dizendo que cativar demanda brandura, instruir demanda precisão e influenciar demanda força (De Or. II 29, 128). Para tanto, a reputação do orador - ou a impressão por ele provocada - ganha larga vantagem para a persuasão, considerado o fato de que a sociedade romana respeitava a autoridade pessoal e a tradição dos ancestrais sobretudo no âmbito da vida pública (Barber, 2004, p. 3; Kirby, 1990, p. 16-18).

Na tarefa de influenciar (mouere; commouere), o objetivo do orador é inflamar o ânimo da audiência (Cíc. De Or. II 45,188; 46,191; 47,197; 53,212-213) por meio da insinuação das afecções, que a atraem para a causa pelo ódio, pelo medo, pelo luto, pelo desejo, pela admiração ou por qualquer outra emoção que o orador desperte ou demonstre sentir durante o discurso (Cíc. De Or. II 46,190). É um tipo essencial de argumento (Cíc. De Or. II 49,200), distinto da tarefa de cativar pelo ponto de partida (essa se origina do orador; aquele, da audiência) e pela natureza da afecção que suscita: o argumento ético é caracterizado pela lenitas e o argumento patético, por ser atrox ou uehemens (Cíc. De Or. II 49,200; 213; cp. Quint. Inst. Or. VI 2,8-12). Ademais, o argumento patético exige que o orador anteveja e atenda às exigências da audiência em relação à causa, para assim despertar a emoção desejada ${ }^{8}$. Com efeito, argumentos éticos e patéticos comungam de relações compreensíveis e apropriadas à audiência, na medida em que os argumentos patéticos, ainda que originados da audiência, não teriam significado se não fossem apresentados pelo orador, o locus do argumento ético (Barber, 2004, pp. 27-29; Kirby, 1990, p. 54; Montefusco in Fortenbaugh

8 De Or. II 44,186 Atque illud optandum est oratori, ut aliquam permotionem animorum sua sponte ipsi adferant ad causam iudices ad id, quod utilitas oratoris feret, accommodatam; facilius est enim currentem, ut aiunt, incitare quam commovere languentem; sin id aut non erit aut erit obscurius, sicut medico diligenti, priusquam conetur aegro adhibere medicinam, non solum morbus eius, cui mederi volet, sed etiam consuetudo valentis et natura corporis cognoscenda est, sic equidem cum adgredior in ancipiti causa et gravi ad animos iudicum pertractandos, omni mente in ea cogitatione curaque versor, ut odorer, quam sagacissime possim, quid sentiant, quid existiment, quid exspectent, quid velint, quo deduci oratione facillime posse videantur. cp. Quint. Inst Or. VI 2,5 ubi vero animis iudicum vis adferenda est et ab ipsa veri contemplatione abducenda mens, ibi proprium oratoris opus est. 
e Mirhady [org.], 1994, pp. 74-75; 78-83).

Para instruir (docere), a organização dos argumentos deve oferecer (ou parecer oferecer) as provas a partir do próprio discurso. Isso significa dizer que o discurso deve oferecer um processo verbal cujos agentes de persuasão sejam, essencialmente, racionais (cf. Kirby, 1990, p. 79).

Nas Partições Oratórias, Cícero define o argumento como o que é passível de comprovação, sendo encontrado para estabelecer a credibilidade (fides; q.v. Part. Or. 5). Àqueles que estão relacionados ao próprio assunto, ele chama inseridos (insitum) e os divide em definição (definitio), antítese (ex contrario), causa e consequência (ex causis; ex effectis) e comparação (comparatio), subdivididos em outros tipos ainda mais específicos. O dever do orador é dispô-los no discurso tanto para estabelecer a credibilidade quanto influenciar, pois é disso que obtém sucesso na persuasão.

Como o objetivo dos três gêneros oratórios (deliberativo, judiciário e demonstrativo) é distinto, o argumento deve ser diferente e cuidadosamente elaborado em cada um deles (Part. Or. 11-14). No caso das deliberações, de que as Ep. ad Caes. servem como exemplo, todos os argumentos devem convergir para a utilidade e para a necessidade. Isso quer dizer que, para quem aconselha, convém observar o que pode ou não pode acontecer; o que é fácil ou não é fácil de se fazer e, por fim, o que é bom ou não é, de maneira que seja feito apenas o que é útil e necessário (Part. Or. 83-86). Deriva disso a acomodação do discurso à verdade e à opinião da audiência, essa última entendida como a disposição boa ou ruim demonstrada para a persuasão. Nesse sentido, os argumentos devem considerar se a audiência é rude e indouta (porque preferirá sempre a utilidade à honestidade) ou humana e polida (porque preferirá a honestidade sobre todas as coisas) (Part. Or. 90).

A estrutura convencional do discurso ou a disposição (dispositio), tal como já aparece na Retórica a Herênio (I 4) e no De inventione (I 25,18 - 56,109), será objeto de atenção no segundo capítulo desta tese. Ela compreende o exórdio (exordium) ou proêmio, a narração (narratio) ou o estabelecimento dos fatos, a partição (compartitio) ou enumeração de tópicos que servem de objeto 
ao discurso, a confirmação (confirmatio) ou argumentação, a repreensão (reprehensio) ou refutação do oponente e, por fim, a peroração (peroratio) ou conclusão do discurso. Sua importância reside no fato de que é tão importante saber o que dizer quanto como dizer, e por isso Quintiliano compara a disposição com o ato de esculpir uma estátua (Inst. Or. VII Pr. 2), distinta dessa apenas pelo fato de que os argumentos, e não somente a beleza estética, ditam, pela força que possuem, a ordem do discurso.

Integra também o segundo capítulo desta tese o estudo da elocutio nas Ep. ad Caes., uma vez que essa parte do discurso traslada para a linguagem as ideias encontradas na inuentio e ordenadas na dispositio (Lausberg, 1976, § 453). Com efeito, a elocução é definida ora como roupagem do discurso (Cíc. De Or. I 31,142), ora como materizalização das ideias (Rhet. Her. I 2,3; Cíc. De inv. I 7,9; Quint. Inst. Or. VIII Pr. 15) (Lausberg, 1976, § 455), e por tal razão ela abrange tanto as palavras isoladamente (uerba singula) quanto as palavras dentro do período (uerba coniuncta).

Devido à ausência de registro que possibilite rastrear a data e o local possíveis para o surgimento das Ep. ad Caes., ou mesmo da indicação de elas terem sido escritas por um orador em formação, por um professor que fizesse delas material didático ou mesmo por um diletante, optei, portanto, pela análise dos elementos constitutivos desses documentos segundo a preceptiva retórica de Cícero e de Quintiliano. Cícero, de um lado, deixou uma vasta obra tanto sobre a formação do orador quanto sobre a formulação do próprio discurso, o que o tornou, ainda na antiguidade, uma referência para o estudo da retórica. Já Quintiliano, ao retomar muitas ideias de Cícero nas Instituições Oratórias, promove uma discussão ampla sobre a competência da filosofia, da história e das letras na formação do orador perfeito. Por essa razão, a retórica é tratada por ele como uma doutrina geral da educação, na medida em que reúne preceitos para a formação do orador em particular e, em geral, do homem (Vasconcelos, 2002, p. 13; 15; cp. Inst. Or. I 1,9). Não foge a esse propósito a reunião e o comentário de matrizes bastante distintas entre si (cp. Inst. Or. II 14-21), como síntese das ideias que então havia sobre a disciplina. 
A retórica teve como papel sistematizar a produção de discursos na antiguidade tanto ao estabelecer as regras da arte (ars), quanto ao regular a produção do discurso de parte (oratio) e organizá-lo em grupos conforme a matéria e a elaboração (Lausberg, 1994, §§ 28-45). Inicio, pois, relembrando que uma obra (opus; q.v. Cíc. De or. I 35,164) pode ser executada conforme um planejamento inicial, ou antes, conforme o domínio, ou ciência (scientia; q.v. Cíc. De or. I 3,9), de princípios ou padrões organizados logicamente (cf. Lausberg, 1994, §3), nos quais, com base em Rhet. Her. I 3 (ars est praeceptio, quae dat certam uiam rationemque dicendi; “a arte é o preceito que dá o caminho certo e o método de discursar”), encontro o conceito de arte (ars) ${ }^{9}$.

O caráter preceptivo da arte é assente entre os rétores romanos. Diz, por exemplo, Cícero (De or. I 4.14-17) que, por inspiração grega, os romanos superaram seu talento natural (ingenium) em favor do estudo (doctrina), para cujo proveito concorrem ao mesmo tempo a ciência de inúmeros assuntos e a ciência de todas as afecções de que está suscetível a humanidade (às quais se somam certa espirituosidade e uma cultura digna do homem livre, obtida também com a ciência de toda a história e poder dos precedentes, da lei e do direito civil). Disso entendo que a arte, ou antes, as $\operatorname{artes}^{10}$, são suscetíveis de aprendizado (q.v. Quint. Inst. Or. II 14,5 ars erit quae disciplina percipi debet; “a arte será o que deve ser apreendido pelo estudo”) ${ }^{11}$ uma vez que derivadas da experiência, e que a obra, portanto, é uma construção (exaedificare, exaedificatio; q.v. Cíc. De or. I 35,164) dependente da racionalização dessa experiência.

9 Em Her. I 3, são indicados os elementos que o orador precisa conhecer para a excelência em seu ofício - as cinco partes da retórica - alcançados por três meios: arte, imitação e exercício. Cícero retoma esses três meios aplicados às cinco partes da retórica citando o exemplo de Gaio Pisão em Brutus, lxxviii. 272 (itaque tantos processus efficiebat ut evolare, non excurrere videretur; eratque verborum et dilectus elegans et apta et quasi rotunda constructio; cumque argumenta excogitabantur ab eo multa et firma ad probandum tum concinnae acutaeque sententiae; gestusque natura ita venustus, ut ars etiam, quae non erat, et e disciplina motus quidam videretur accedere. Vereor ne amore videar plura quam fuerint in illo dicere); no De or. I 26,113 (neque vero istis, de quibus paulo ante dixit Antonius, scriptoribus artis rationem dicendi et viam, sed naturam defuisse), a ars é contraposta à natura (cf. Lausberg, 1994, §1). Com exceção da arte, que é motivo de divergência em relação à sua oposição ao engenho, tanto a imitação quanto o exercício constituíam ponto pacífico porque estabeleciam uma relação entre o orador e um modelo (cf. Lausberg, 1994, §2).

10 A eloquência é tida aqui como uma arte entre as demais artes (q.v. Cíc. De or. I 1,2; I 2,5 solesque non numquam hac de re a me in disputationibus nostris dissentire, quod ego eruditissimorum hominum artibus eloquentiam contineri statuam, tu autem illam ab elegantia doctrinae segregandam putes et in quodam ingeni atque exercitationis genere ponendam). Sobre a condição da eloquência como arte em Cícero, q.v. Scatolin, 2009, pp. 3034.

11 É de se notar que Cícero (De Or. II 21,89) indica a prática como forma adequada de se aprender a arte da eloquência e que o mestre é o modelo de imitação tomado pelo aluno (q.v. Scatolin, 2009, pp. 51-52). 
Porque a arte pode ser aprendida, duas são as ocasiões favoráveis à prática (Lausberg, 1994, §6): o jogo (Cíc. De or. II 21,89 ludum putaret esse ad discendum; “julgava que o jogo servia para aprender”) e o uso sério (Quint. Inst. Or. II 18,5 Si tamen una ex tribus artibus habenda sit, quia maximus eius usus actu continetur; "mas caso se deva considerar uma das três artes, seu uso mais importante deve estar na ação”), ambos estreitamente relacionados.

Pertencem ao jogo a imitação e o exercício, que compõem com a arte a tríade do que deve o orador conhecer (q.v. Rhet. Her. I 3). Definem-se, respectivamente, como aquilo que nos impele com razão diligente para sermos parecidos com outros ao discursar e como o uso repetido e o costume de discursar (ibid.).

O termo imitação (imitatio, mímesis) possui significado muito vasto, e por isso merece melhor especificação, uma vez que apenas numa direção tomo-o nesta tese. O verbo miméomai abrange três modos de se fazer a mesma coisa - "parecer fazer o mesmo", "tentar fazer o mesmo" e “fazer efetivamente o mesmo” (Veloso, 2004, p. 174) - e recobre as noções de simulação, emulação e identidade (ibid.), acerca do que reconheço (q.v. Veloso, 2004, pp. 218 et seq.) que a imitação é emulativa (e nesse sentido tomo o termo imitação nesta tese) quando houver um modelo ${ }^{12}$. Isso ${ }^{13}$ é confimado por Quintiliano, que menciona sempre a imitação a partir de um modelo para superá$10^{14}$

Em Cícero, a imitação recai sobre as virtudes do modelo ${ }^{15}$, do qual o aprendiz deve servir-se

12 Russell (in West \& Woodman, 2001 [1979], p. 16) identifica cinco princípios para a imitação, estabelendo (e aqui traduzo e reproduzo-o fielmente) que:

(i) O objeto deve ser digno de imitação;

(ii) O espírito em vez da letra deve ser reproduzido;

(iii) A imitação deve ser tacitamente admitida, no entendimento de que um leitor bem informado reconhecerá e aprovará o empréstimo;

(iv) O empréstimo deve ser feito por iniciativa própria, graças ao tratamento individual e assimilação do seu novo lugar e propósito;

(v) O imitador deve pensar que está competindo com seu modelo, mesmo sabendo que não pode vencer.

Tais princípios visam esclarecer questões como o plágio e a emulação, bem como respeitar o princípio de que o imitador deve recolher o que há de melhor em mais de um modelo, e não concentrar-se em apenas um.

13 cf. Ar. Poet. 15, 1454b 91-10; Rhet. I 2, 1357b 26-36; 1356b 3-16.

14 Inst. Or. X 2, 3 necesse est aut similes aut dissimiles bonis simus: similem raro natura praestat, frequenter imitatio; $\mathrm{X}$ 2, 4 Ante omnia igitur imitatio per se ipsa non sufficit, vel quia pigri est ingenii contentum esse iis quae sint ab aliis inventa; X 2, 8 nihil autem crescit sola imitatione.

15 De Or. II 22, 90 Ergo hoc sit primum in praeceptis meis, ut demonstremus, quem imitetur [atque ita, ut, quae maxime excellent in eo, quem imitabitur, ea diligentissime persequatur]. 
de maneira decorosa, buscando cuidadosamente os elementos que nele se sobressaem ${ }^{16}$. Como resultado, a escolha do modelo produz a riqueza de temas e a riqueza de palavras e, havendo nobreza nos temas (honestas in rebus) tratados, do tema (res) nasce o brilho das palavras (splendor in verbis $)^{17}$. A arte, pois, converge para os ornamentos do discurso quando exercitada ${ }^{18}$.

Não só a Retórica a Herênio (q.v. Rhet. Her. I 3), como ainda Cícero e Quintiliano estabelecem as relações entre imitação e exercício: Cícero reconhece que é por meio do exercício que se tira proveito da imitação ${ }^{19}$ e Quintiliano, elegendo-a parte essencial da arte $^{20}$, propõe a imitação como integrante já dos primeiros exercícios de formação do orador ${ }^{21}$. Entre os vários modelos para imitação, Quintiliano sugere oradores e historiadores ${ }^{22}$. É a isso que, entre os praeexercitamina, destina-se a prosopopeia.

\section{Definição de prosopopeia}

O exercício da prosopopeia é definido por Teão, Hermógenes, Aftônio, Libânio, Nicolau e

Prisciano. Hermógenes denomina esse exercício de etopeia (Progym. 20), subdividindo-o quanto ao objeto imitado (imitação do caráter de um personagem - real ou imaginário, determinado ou indeterminado - ou de uma coisa), quanto à estrutura (simples ou dupla) e quanto ao tipo (moral,

16 De Or. II 22, 91 Nihil est facilius, quam amictum imitari alicuius aut statum aut motum; si vero etiam vitiosi aliquid est, id sumere et in eo vitio similem esse non magnum est, ut ille, qui nunc etiam, amissa voce, furit in re publica, Fufius, nervos in dicendo C. Fimbriae, quos tamen habuit ille, non adsequitur, oris pravitatem et verborum latitudinem imitatur; sed tamen ille nec deligere scivit, cuius potissimum similis esset, et in eo ipso, quem delegerat, imitari etiam vitia voluit.

17 De Or. III 31, 125 Rerum enim copia verborum copiam gignit; et, si est honestas in rebus ipsis, de quibus dicitur, exsistit ex re naturalis quidam splendor in verbis. Sit modo is, qui dicet aut scribet, institutus liberaliter educatione doctrinaque puerili et flagret studio et a natura adiuvetur et in universorum generum infinitis disceptationibus exercitatus ornatissimos scriptores oratoresque ad cognoscendum imitandumque delegerit, ne ille haud sane, quem ad modum verba struat et inluminet, a magistris istis requiret.

18 De Or. III 31, 125 ita facile in rerum abundantia ad orationis ornamenta sine duce natura ipsa, si modo est exercitata, delabitur.

19 De Or. II 22, 90 tum accedat exercitatio, qua illum, quem delegerit, imitando effingat atque exprimat.

20 Inst. Or. X 2, 1 Neque enim dubitari potest quin artis pars magna contineatur imitatione.

21 Inst. Or. II 4, 41 (sobre o exercício da narração) Nam fictas ad imitationem fori consiliorumque materias apud Graecos dicere circa Demetrium Phalerea institutum fere constat. Inst. Or. X 1, 3 Nam certe, cum sit in eloquendo positum oratoris officium, dicere ante omnia est, atque hinc initium eius artis fuisse manifestum est, proximam deinde imitationem, novissimam scribendi quoque diligentiam.

22 Inst. Or. II 5, 25-6 Quosdam uero etiam quos totos imitari oporteat et fuisse nuper et nunc esse quidni libenter non concesserim modo uerum etiam contenderim? [26] Sed hi qui sint non cuiuscumque est pronuntiare. Tutius circa priores uel erratur, ideoque hanc nouorum distuli lectionem, ne imitatio iudicium antecederet. 
emotiva e mista), em relação aos quais o orador deverá adequar as modalidades discursivas e o estilo. Também Aftônio (Progym. 34) subdivide o exercício em tipos (idolopeia, prosopopeia e etopeia), concordando, porém, com Hermógenes, em dividi-lo entre as etopeias morais, emotivas e mistas. Prisciano (Praex. IX 27.30) denomina o exercício de allocutio em latim, identificando as mesmas divisões que seus antecessores.

Esse exercício é um dos últimos da série porque se configura, sobretudo, como exercício de estilo. Nele, o orador deve, inicialmente, refletir sobre o caráter próprio daquele que fala e qual é o caráter daquele a quem o discurso é dirigido, assim como a idade que possuem os interlocutores, a ocasião, a circunstância, o lugar e os temas sobre os quais versa. Depois, verificar se não falou de ações importantes de maneira humilde, nem sobre ações insignificantes de maneira sublime, nem sobre ações vulgares de maneira grave, nem sobre ações terríveis de maneira despreocupada ou sobre ações lamentáveis de maneira afetada (Teão Prog. 115.11.8 - 116.11.12).

Teão (Prog. 115.11.8) insere o exercício da prosopopeia nos discursos panegíricos, deliberativos e epistolares ${ }^{23}$. Elementos como o caráter próprio da pessoa que fala e o daquele a quem o discurso é dirigido, o lugar, as circunstâncias e mesmo os feitos (porque se enquadram numa diversidade tal que peçamos, exortemos, dissuadamos, consolemos, peçamos perdão por nossa conduta ou façamos uma outra ação semelhante) determinam a elocução e o tipo de argumento utilizado. Assim, deve o orador, ao exortar, dizer que aquele a quem se exorta tem possibilidades de êxito fácil, belo e adequado por ser útil, justo, piedoso e agradável; que aquele que exorta não é o único nem o primeiro a exortar e, caso o seja, fá-lo consciente de que muito melhor é começar belas obras, porque delas não há arrependimento; que considerará alguma outra iniciativa que tenha tomado em relação ao personagem exortado, e se esse noutra ocasião deixou-se por ele persuadir de algo útil. Deve o orador, ao consolar, dizer que a sensatez e o bom senso devem prevalecer em situações de aflição e de desgraça; que a compaixão tem poder de consolação nos momentos de perda; e, ao pedir perdão, deve o orador dizer que erros podem ser cometidos por

23 Nicolau (Prog. 67) também sugere que o exercício da prosopopeia assuma a forma de epístola pelo fato de que essa espécie exige a escolha da apresentação do emissor e do receptor. 
ações involuntárias, ignorância, azar ou fatalidade. A prosopopeia é, pois, um exercício que expõe caráter (éthos) e/ou afecção (páthos) ${ }^{24}$.

Uma vez que a prosopopeia molda-se à imitação da pessoa e/ou à imitação das palavras da pessoa em situações como diálogos, testamentos ou mesmo para efeito de paródia ${ }^{25}$, pode ser vastamente aplicada. Recebe, em latim, o nome de sermocinatio quando se trata de diálogo entre personagens históricas ${ }^{26}$, podendo ainda tomar a forma de narrativa, especialmente nos discursos indiretos dos historiadores ${ }^{27}$. Trata-se um exercício difícil ${ }^{28}$, mas importante não apenas para 0 orador, como também ao poeta e ao historiador, já que acomoda as palavras à posição e ao caráter da audiência (q.v. Lausberg, 1976, §1148; Bonner, 1949, p. 51 et seq.). O exercício serve, pois, para demonstrar a habilidade discursiva ${ }^{29}$. Quintiliano, por exemplo, admite que esse exercício é realizado preferencialmente por escrito ${ }^{30}$ e nele se considere a fortuna, a posição e a carreira daquele a quem o orador se dirige ${ }^{31}$, raramente falando como advogados e o mais das vezes, como

24 Para exemplificar como a prosopopeia expõe caráter e afecção, Nicolau (Prog. 67) sugere, para aquele, um tema como "o que um covarde diria ao sair para a batalha” (em que o aluno deveria se concentrar no modo de agir de um covarde) e, para essa, “que palavras Agamenão diria ao invadir Troia” (em que o aluno deve perceber que a situação fornece a afecção adequada).

25 Inst. Or. IX 2,31 Ac sunt quidam qui has demum prosopopoiias dicant in quibus et corpora et verba fingimus: sermones hominum adsimulatos dicere dialogous malunt, quod Latinorum quidam dixerunt sermocinationem; 2, 33 Commode etiam aut nobis aliquas ante oculos esse rerum personarum vocum imagines fingimus, aut eadem adversariis aut iudicibus non accidere miramur: qualia sunt "videtur mihi" et "nonne videtur tibi?" Sed magna quaedam vis eloquentiae desideratur.

26 Inst. Or. IX 2,31 Ac sunt quidam qui has demum prosopopoiias dicant in quibus et corpora et verba fingimus: sermones hominum adsimulatos dicere dialogous malunt, quod Latinorum quidam dixerunt sermocinationem.

27 Inst. Or. IX 2,38 Vertitur interim prosopopoiia in speciem narrandi. Unde apud historicos reperiuntur obliquae adlocutiones, ut in Titi Livi primo statim: 'urbes quoque ut cetera ex infimo nasci, deinde, quas sua virtus ac di iuvent, magnas opes sibi magnumque nomen facere'.

28 Inst. Or. III 8, 49 Ideoque longe mihi difficillimae videntur prosopopoeiae, in quibus ad relicum suasoriae laborem accedit etiam personae difficultas: namque idem illud aliter Caesar, aliter Cicero, aliter Cato suadere debebit.

29 Costrino, 2010, p. 39 "O exercício [i.e. a suasoria] versa sobre a habilidade do orador, mas, se ele conseguiria convencer a personagem ou não é impossível de ser julgado, assim como mesmo que se tratasse de oratio, isto é, do chamado discurso verdadeiro (alethinòs lógos, uera oratio), não se poderia julgar do resultado do discurso, que é externo a este e depende dos ouvintes, mesmo verdadeiros, mas tão-só da potência para persuadir, que é inerente ao discurso e independe dos ouvintes, mesmo verdadeiros. Como diz Aristóteles no início da Retórica, assim como não cabe ao médico curar, mas descobrir os meios necessários à cura, assim também não cabe ao orador persuadir, mas descobrir os argumentos necessários à persuasão. Desse modo, nada impede, por extensão, que se entreveja a potência para persuadir inerente, igualmente, a um discurso de aparato, como a declamação. As suasórias versam sobre temas deliberativos, ou seja, de acordo com a classificação aristotélica, sobre ações futuras, sobre o útil e o prejudicial, perante uma assembleia. No entanto, como sabemos, dado o caráter fictício dos temas, nenhuma dessas ações pode ter, de fato, uma resolução, uma vez que são ou sobre temas mitológicos ou históricos, por isso não decidem sobre uma ação futura, mas sim demonstram a habilidade do orador”.

30 Inst. Or. III 8, 49 An eodem modo cogitavit aut eandem personam induit Cicero cum scriberet Cn. Pompeio et cum T. Ampio ceterisve.

31 (ibid.) ac non unius cuiusque eorum fortunam, dignitatem, res gestas intuitus omnium quibus vocem dabat etiam imaginem expressit, ut melius quidem sed tamen ipsi dicere viderentur? 
filhos, pais, homens ricos, velhos, pessoas bem ou mal humoradas, avarentos, supersticiosos, covardes ou zombadores.

Relacionando a prosopopeia ao estilo, entretanto, Quintiliano a coloca entre as figuras de pensamento (Inst. Or. IX 2, 29-37). Assim, a prosopopeia serviria como expediente destinado a enriquecer o discurso, a deduzir da citação que Quintiliano faz de Cícero (Inst. Or. IX 2, 29-37 cit. Cíc. Or. 85 Non faciet rem publicam loquentem nec ab inferis mortuos excitabit nec acervatim multa frequentans una complexione devinciet; “Não fará com que a república fale nem trará os mortos do abismo, nem encerrará em um só período muitas coisas acumulando-as confusamente”), para o qual essa figura exige audácia por não pertencer a um estilo remisso (ibid. Valentiorum haec laterum sunt; “Essas coisas pertencem à disposição dos mais valentes”). Como figura de pensamento, sua finalidade é servir de estratégia para antever o argumento do adversário, reproduzir conversas ou mover os ânimos da audiência ${ }^{32}$.

As Ep. ad Caes., definindo-se como suasórias, aproveitam-se da prosopopeia como forma de enriquecer o estilo. De acordo com o tema (res, materia), com o gênero adotado (deliberativo ou judiciário) e com a familiaridade do declamador em relação ao tema (de que se entende o uso da 3a. ou da 1a. pessoa) (Bonner, 1949, p. 51 et seq.), o aluno tinha a tarefa de declamar o discurso na forma de uma disputa judicial (controuersia) ou de um conselho a uma pessoa num dilema ético (suasoria; q.v. Inst. Or. III 8, 49; consilium dare, Sen. Suas. VI 11; Juv. I 16; Inst. Or. III 8, 49 e III 8, 46 apud Bonner, 1949, p. 53, n. 1). Assumindo a forma de solilóquio, o exercício da prosopopeia torna-se útil para as suasórias porque fazer uma advertência, persuadir (suadere), como César, Cícero ou Catão resulta em diferentes formas de persuasão (Inst. Or. III 8, 49 et seq.). O conselho é dado em caráter íntimo e privilegia temas tanto poéticos quanto históricos, primando pela consistência (concitatam orationem) e pela generosidade da linguagem (verbis effusiorem). Para elevar a linguagem, é conveniente escolher personagens importantes - reis, príncipes, o senado e o

32 Inst. Or. IX 2,30 His et adversariorum cogitationes velut secum loquentium protrahimus (qui tamen ita demum a fide non abhorrent si ea locutos finxerimus quae cogitasse eos non sit absurdum), et nostros cum aliis sermones et aliorum inter se credibiliter introducimus, et suadendo, obiurgando, querendo, laudando, miserando personas idoneas damus. 
povo - e um grande tema; adaptando-se as palavras à matéria, nasce, do esplendor do tema, o brilho. Isso, segue Quintiliano (Inst. Or. III 8, 62 et seq.), não ocorre nas deliberações reais, que devem estar livres da afetação.

\section{Definição de epístola}

O aconselhamento é, entretanto, função mesma da epístola. Sendo essa um sermo destinado a falar com ausentes, Cícero (Ad fam. II 4,1) reconhece serem muitas as suas espécies, mas as distribui em três grupos genéricos (Santos, 1997, pp. 68 et seq.): aquele que traz notícias aos ausentes (ut certiores faciamus absentes), aquele de natureza familiar e jocosa (familiare et iocosum) e aquele de natureza severa e grave (seuerum et graue). Àquelas duas primeiras espécies convêm os assuntos domésticos e a doutrina, respectivamente (res domestica; studia artium et doctrina cp. Cícero, Ad Att. 7. 5. 4-5), quando à última espécie convêm os assuntos concernentes à res publica.

Distinguem-se ainda os três grupos na configuração, ou seja, enquanto ao ut certiores faciamus absentes se equipara a narração - narrare - ao familiare et iocosum se equipara o gracejar - iocari - e, por fim, ao seuerum et graue, o encarregar - mandare (cp. Cícero, Ad Att. V 5,1). Mas não apenas isso. O seuerum et graue desdobra-se ainda em outros dois grupos conforme a finalidade, a saber, a solicitação a alguém em nome de terceiros - commendare - e o aconselhamento a alguém sobre um terceiro - monere. Em relação àquele grupo, ainda, dá-se o nome de commendatio (recomendação) à solicitação de uma ação em relação a outrem e consilium (conselho) em relação a si mesmo (cp. Cícero, Ad Att. III 11,2).

Demétrio, a fonte mais antiga sobre esse assunto, trata da epístola como um dos gêneros que se servem do estilo simples. Ele insere, em seu tratado sobre o estilo, 12 parágrafos acerca do estilo epistolar (De eloc. 223-235), esclarecendo que esse deve ser gracioso e simples, devendo ceder lugar à moderação do tamanho e à expressão dos caracteres em uma composição livre. 
Por estilo simples, Demétrio entende aquele que se utiliza de palavras no sentido próprio e comum (De eloc. 190), de forma que seja claro. Estilo simples, e, portanto, claro, é aquele que é produzido não apenas pelo uso próprio das palavras, mas também pelo encadeamento delas. Isso o caracteriza como um estilo adequado para a leitura (De eloc. 193), porque dispensa a declamação e a representação teatral. O estilo claro é impassível, em oposição à representação teatral e à declamação, porque não conta com os gestos e com os movimentos exigidos numa performance. Também dispensa ambiguidades, profusão e construções indiretas. Ao contrário, exige a ordem natural das palavras, pressupondo a colocação do nominativo no início da sentença, seguido do acusativo e então dos demais casos sem, contudo, delongá-la. Esses elementos reunidos servem como atributo de persuasão (De eloc. 209 et seq.), mostrada na precisão advinda da clareza na evidência de circunstâncias gerais ou particulares e pela força derivada do uso de um vocabulário nem raro nem pomposo.

Por gracioso, figurado em seu tratado como atributo do estilo elegante (De eloc. 128 et seq.), Demétrio entende o que do uso de uma linguagem graciosa produz expressão graciosa e brilhante. É, pois, o estilo da poesia, e também o do diálogo platônico. Procedem as graças da linguagem (os termos que embelezam o pensamento, e.g., asas acetinadas de um pássaro no começar da primavera) e do tema (e.g., os jardins das ninfas, os cantos de himeneu e os amores). Do tema, a graça nasce ou quando o tema é por natureza gracioso (e.g. a primavera) ou quando o tema é repulsivo por natureza, mas se converte em agradável por obra do escritor. Da linguagem, a graça nasce tanto da brevidade, que torna gracioso mesmo o pensamento desagradável (porque, ao contrário, o pensamento alargado em grande número de palavras torna-se narração), quanto da ordem destas palavras. Daí o uso das figuras, como a repetição, a anáfora, a metáfora, a alegoria e, especificamente na comédia, a hipérbole. No diálogo platônico, contudo, a graça deve-se ao ritmo, nem absolutamente métrico nem não-métrico (De eloc. 183 citando Pl. Rep. III 411A), o que também está relacionado mais à ordem das palavras do que ao pensamento e ao vocabulário.

A atribuição do estilo gracioso ao diálogo platônico interessa-me, sobretudo, porque em $D e$ 
eloc. 223 e 227, Demétrio compara o diálogo à epístola, lembrando, porém, que essa deva ser mais elaborada do que aquele, ao pressupor não a improvisação do diálogo (bem entendido, voluntária, na medida em que o diálogo platônico é também discurso sujeito a regras), mas o cuidado de um brinde dado pelo seu autor. Compartilha do diálogo, todavia, a descrição dos caracteres, pois, assim como a caracterização da personagem no diálogo, a epístola retrata o caráter de seu escritor com o vigor que existe em qualquer outro gênero de discurso, sendo nela, porém, acentuado; mas jamais superando o estilo elegante da poesia. O mesmo diz Caio Júlio Victor, no cap. XXVII de sua Arte retórica, ao separar as epístolas em duas espécies, denominando-as como sendo as de negócios públicos (próximas daquelas que Cícero denomina como de natureza severa e grave em razão de sua matéria) ${ }^{33}$ e as familiares. Naquela espécie, e de acordo com Demétrio (De eloc. 235; 128 et seq.), o estilo corresponde ao gracioso porque "requer tanto a gravidade dos períodos quanto a luminosidade das palavras, o adorno do uso das figuras e finalmente todos os preceitos oratórios, com a restrição de que, porém, possamos subtrair alguma coisa da riqueza mais elevada e o discurso por si só explicite eloquência” (Caio Júlio Victor, A.R. XXVII In hoc genere et sententiarum pondera et verborum lumina et figurarum insignia conpendii opera requiruntur atque omnia denique oratoria praecepta, una modo exceptione, ut aliquid de summis copiis detrahamus et orationem proprius sermo explicet), quando às familiares convém a brevidade.

Tanto Caio Júlio Victor (A. R. XXVII), quanto Demétrio (De eloc. 228) concordam que, tal qual a expressão ordenada, a epístola demanda cuidado com a extensão. Para Caio Júlio Victor, a brevidade diferencia epístolas familiares das epístolas de negócios públicos ${ }^{34}$; para Demétrio, epístolas demasiado longas e pomposas não são, em respeito à verdade, epístolas, mas tratados com cabeçalho epistolar (loc. cit.).

Demonstram cuidados com a extensão em suas epístolas Cícero, Sêneca e Plínio, o Jovem. Cícero, por exemplo, ora demonstra prazer com a abundância (ubertas) nas epístolas de Ático, ora

33 Prova-o o passo de Caio Júlio Victor, A. R. XXVII (grifo meu) sunt enim aut negotiales aut familiares. Negotiales sunt argumento negotioso et graui; cp. com Cíc. Ad fam. II 4,1 (grifo meu) Reliqua sunt epistularum genera duo, quae me magno opere delectant, unum familiare et iocosum, alterum seuerum et graue.

34 A. R. XXVII 4 Si quid etiam eruditius scribas, sic disputa, ut ne modum epistolae corrumpas. In familiaribus litteris primo brevitas observanda. 
reclama a falta de assunto em suas epístolas ${ }^{35}$, lembrando, porém, que se deva escrever muito, quando muito exista o que dizer ${ }^{36}$. Confirma a brevidade em relação ao conteúdo a epístola 45 de Sêneca $^{37}$ e a epístola 2.5 de Plínio, o Jovem ${ }^{38}$. Pensa-se, pois, a brevidade como virtude do discurso que pretenda trazer informações (ut certiores faciamus absentes) aproximando emissor e receptor ${ }^{39}$.

Tardiamente, pensa-se a concisão como virtude quando não afete a clareza. Quer dizer, a concisão é virtude desde que não obscureça a expressão, de forma a fazer com que a epístola se afaste do estilo simples (Greg. Naz. Ep 51. 4; Caio Júlio Victor A.R. XXVII); assim, a epístola admitiria, inclusive, a citação de trechos de fábulas e de histórias, provérbios e doutrinas filosóficas para lhe conferir brilho (Pseudo-Lib. Ep. Char. 50).

A depreender de Filóstrato de Lemnos (De Ep. II 257. 29 - 258. 28), a concisão é virtude de todos os tipos de epístolas. Ele a divide em tipos segundo os modelos de uso do gênero - entre os filósofos, generais, imperadores e rétores - lembrando que seu estilo deve ser simples e gracioso, e de expressão concisa e clara (cp. Demétrio e Caio Júlio Victor).

Diz ainda o mesmo Filóstrato de Lemnos (loc. cit.) que a expressão deve evidenciar quem somos, porque a clareza evita a vulgaridade. Essa relação entre epístola e reflexão do caráter de quem a escreve já comparecera em Cícero ${ }^{40}$ e em Sêneca ${ }^{41}$, e, no que concerne à descrição do gênero, diz Demétrio (P. H. 227) que nenhuma outra forma de composição apresenta mais evidentemente o caráter de quem escreve do que a epístola, i.e, se a epístola reflete o caráter de

35 Ad Att XI 4,1 meas litteras quod requiris, impedior inopia rerum quas nullas habeo litteris dignas; IV 16,1 sed haec epistularum frequentia non tam ubertate sua quam crebritate delectavit.

36 Ad Att XI 25,1 scribas ad me quicquid veniet tibi in mentem cum habebis cui des et dum erit ad quem des; quod longum non erit.

37 Sed ne epistulae modum excedam, quae non debet sinistram manum legentis implere, in alium diem hanc litem cum dialecticis differam nimium subtilibus et hoc solum curantibus, non et hoc.

38 Ep. 2. 5.13 sed iam finem faciam ne modum, quem etiam orationi adhibendum puto, in epistula excedam.

39 Cic. Ad fam. XV 14,1 Id quoniam non accidit, utemur bono litterarum et eadem fere absentes, quae, si coram essemus, consequeremur; Ad Q. fr. I 1,37 illud, quod est epistulae proprium, ut is, ad quem scribitur, de iis rebus, quas ignorat, certior fiat, praetermittendum esse non puto; Plin. Ep. 1. 5. 17 Haec tibi scripsi, quia aequum erat te pro amore mutuo non solum omnia mea facta dictaque, verum etiam consilia cognoscere; 3.20.11 Habeant nostrae quoque litterae aliquid non humile nec sordidum, nec privatis rebus inclusum.

40 Ad fam. XVI 16, 2 amo te omnibus equidem maximis de causis, verum etiam propter hanc vel quod mihi sic, ut debuisti, nuntiasti. Te totum in litteris vidi.

41 Ep. Mo. 40, 1 Quod frequenter mihi scribis gratias ago; nam quo uno modo potes te mihi ostendis. Numquam epistulam tuam accipio ut non protinus una simus. Si imagines nobis amicorum absentium iucundae sunt, quae memoriam renovant et desiderium [absentiae] falso atque inani solacio levant, quanto iucundiores sunt litterae, quae vera amici absentis vestigia, veras notas afferunt? Nam quod in conspectu dulcissimum est, id amici manus epistulae impressa praestat, agnoscere. 
quem a escreve, sua virtude está em ser fidedigna ${ }^{42}$.

Tomo expressão do caráter (éthos; persona) como virtude do discurso, passível de ser obtida por meio de expedientes internos e externos a ele e identificada como tal pelos rétores. Diz Hermógenes (Peri Ideon 352. 7 et seq.), por exemplo, que a fidedignidade, apesar de indefinível, é essencial ao método, às figuras e à expressão. Ela reside no pensamento moderado, i.e., que é fácil de ser reconhecido, que exclui o vulgar e é sincero, p. ex. a exclamação. Privilegia o assíndeto e a apóstrofe entre as figuras de linguagem, e o enunciado em forma de resposta, como método. A expressão rude, veemente, de invectiva e que apresente o estado do ânimo também é válida para a expressão do caráter no discurso (cp. Ar. Rhet 1408a), bem como o comentário pessoal (cp. Dem. P.H 232 e Ar. Rhet 1395b, sobre a máxima e Ret. a Alex. 7, 4-14, sobre a obtenção da verossimilhança).

Por composição livre, Demétrio ( $P . H$ 229) entende aquela que não se subordina a um estilo elevado, típico, por exemplo, do discurso judicial, i.e, exige o uso do sermo cotidianus, sem porém apropriar-se da prolixidade e descontinuidade do diálogo. Se, de um lado, a naturalidade é uma virtude confirmada por grande parte dos rétores (Dem. P. H 223, 226, 229; Quint. Inst. Or IX 4, 19; Greg. Naz. Ep 51, 5, 7) e praticada por Cic. Ad fam IX 21, 1; Sen. Ep 75, 1; Pl. Ep 9, 33; 7, 9, por outro lado, muitos deles mesmos prescrevem um estilo entre o vernacular e o ático (Filóstrato De Ep. II 257. 29 - 258. 28; Pseudo-Libânio, Ep. Char 47; Greg. Naz. Ep. 51, 4), ou mesmo elaborado, artístico (Dem, $P . H$ proêmio; Caio Júlio Victor, $A$. $R$. XXVII 20-25).

Aparente contradição é resultado da necessidade de correção (politae litterae q.v. Pl. Ep 1, 16; 7, 13), relacionada tanto à diligência da redação (curatius; curiosus Pl. Ep 1, 1; 9, 28) - o que pressupõe a ars - quanto à moderação dos ornatos e das afecções (Pl. Ep 7, 9; 9, 33), esses relacionados, por sua vez, ao estilo gracioso e simples e à concisão, breuitas.

Deve-se saber, pois, o que seja uma epístola, o que dizer nela, qual o estilo e em que tipos

42 Importante dizer, aqui, que entendo fidedignidade como fides, resultado do pacto entre orador e audiência que constitui a legitimidade do próprio orador para o ato de discursar e para a qualificação do discurso para a persuasão; cf. Chiappetta, 1997, pp. 80-85; 97-116. 
ela é dividida (Pseudo Lib. Ep. Ch. 1). Em relação a esses, a contagem prescritiva varia muito, sobretudo através do tempo. Cícero, por exemplo, menciona apenas dois tipos em Pro Flacco 37 (non modo in publicis sed etiam in privatis litteris), e ainda três em Ad fam. II 4, 1; IV 13, 1; VI 10, 4, conforme a informação que nelas constam. Já Demétrio, em vinte e um tipos, segundo o estilo, e Pseudo-Libânio, em quarenta e um tipos. Caio Júlio Victor parece seguir Cícero, e Filóstrato separaas em grupos genéricos que expressam pedido, acordo ou desacordo, ataque ou defesa e demonstração de afeto.

A análise das Ep. ad Caes. conduzirá uma discussão acerca das razões “didáticas” para exortar um imperador a debelar o perigo de uma guerra civil, de um lado, e apresentar uma definição de gênero para esses documentos, de outro. Como se verá, o primeiro e o segundo capítulo tratarão especialmente da relação entre os princípios dados pela retórica e pela filosofia para o aconselhamento, o arranjo dos argumentos no discurso e a imitação de Salústio. Procedendo assim, sigo o conselho de Quintiliano, para quem, durante a instrução, o mestre deve tudo observar meticulosamente no discurso do aluno: como conciliar os ânimos no proêmio; a clareza, a brevidade e a credibilidade da narrativa; o planejamento e o artifício oculto pelo discurso; a divisão da matéria; o argumento denso ou delicado e, enfim, como governar as afecções da audiência, abrindo caminho para a persuasão e fazendo as afecções refletirem as palavras ${ }^{43}$. A partir dessa argumentação, passarei para a etapa seguinte, i.e, a conclusão sobre o gênero dessas epístolas. Em anexo, o texto original e a tradução das duas epístolas.

43 Inst Or. II 5,6 Nam mihi cum facilius, tum etiam multo videtur magis utile facto silentio unum aliquem (quod ipsum imperari per vices optimum est) constituere lectorem, 7. ut protinus pronuntiationi quoque adsuescant: tum exposita causa in quam scripta legetur oratio (nam sic clarius quae dicentur intellegi poterunt), nihil otiosum pati quodque in inventione quodque in elocutione adnotandum erit: quae in prohoemio conciliandi iudicis ratio, quae narrandi lux brevitas fides, quod aliquando consilium et quam occulta callidibrevitas 8. (namque ea sola in hoc ars est, quae intellegi nisi ab artifice non possit): quanta deinceps in dividendo prudentia, quam subtilis et crebra argumentatio, quibus viribus inspiret, qua iucunditate permulceat, quanta in maledictis asperitas, in iocis urbanitas, ut denique dominetur in adfectibus atque in pectora inrumpat animumque iudicum 9. similem iis quae dicit efficiat; tum, in ratione eloquendi, quod uerbum proprium ornatum sublime, ubi amplificatio laudanda, quae virtus ei contraria, quid speciose tralatum, quae figura verborum, quae leuis et quadrata, virilis tamen compositio. 


\section{Parte I}

Arte, imitação e exercício nas Epistulae ad Caesarem 


\section{Capítulo 1 - Invenção nas Epistulae ad Caesarem}

\section{Conciliare}

Dentre os officia oratoris, a invenção soma o desenvolvimento da matéria (excogitatio rerum) ao talento do orador (ingenium) e ao conhecimento técnico (doctrina) a fim de tornar a causa provável (Lausberg, 1994, § 260). Cada parte do discurso, portanto, é submetida a regras que direcionam a matéria no sentido de produzir a persuasão. Com essa finalidade, o orador utiliza expedientes distintos, que apontam ora para o intelecto, ora para as afecções da audiência (Cíc. De Or. II 27, 115; cf. II 28, 121; 29, 128; 77, 310 ${ }^{44}$. Assim, na acomodação do discurso às regras da invenção, é conveniente (aptum) aplicar esses expedientes às partes do discurso de forma a captar a benevolência logo no exórdio, instruir o ânimo na narração e na confirmação e influenciar o ânimo do público no exórdio e na peroração - muito embora se reconheça que esse último recurso seja objeto de atenção, na verdade, do discurso como um todo (Lausberg, 1994, §§ 256-258). Ao analisar a invenção nas Ep. ad Caes. e compará-las às obras de Salústio, meu intuito é verificar em que medida, nesses documentos, constroi-se a persona discursiva e a do destinatário do discurso,

44 Opto pela terminologia ciceroniana adotada no De Oratore (conciliare commouere docere; De Or. II 27, 115) em contraste com a terminologia que o mesmo Cícero utiliza em outras obras suas (Br. 197 ff.; Op. gen. or. 3;), nas quais a substituição de commouere por delectare enfatiza o peso do estilo sobre a atividade do orador (cf. Montefusco in Fortenbaugh e Mirhady [org.], 1994, pp. 66-94). De acordo com essa terminologia, conciliare e commouere opõem um elemento patético ao elemento racional de docere (De Or. II 27, 114; 52, 178), a partir do que entendo a enumeração das virtudes do aconselhador e do aconselhado nas Ep. ad Caes. Essa enumeração serve, ao mesmo tempo, para forjar o caráter do orador (effingere mores oratoris) e para expressar o caráter do cliente (exprimere mores), o que estabelece a fides (fides facere) ou a confiança necessária para a persuasão (cf. De Or. II 43, 182-184). 
bem como apresentar as partes das Ep. ad Caes. em que a imitação de Salústio é explícita.

Levo em consideração, inicialmente, o prólogo das duas monografias salustianas - a Conjuração de Catilina e a Guerra Jugurtina, em relação aos quais de muito já se tratou, especialmente pela importância que as obras possuem dentro da historiografia latina. Delas, ressalto apenas a recorrência de uma figura - a antítese (Goettems, 1993, p. 118) - que exerce função essencial para a narrativa (ibid.) de ambas as monografias, porque estabelece as oposições que explicam a origem das dissensões entre os humanos, em geral, e as diferenças entre o passado e o presente romanos conforme as estabelece o historiador, em particular. Analisando os conceitos do exórdio da Conjuração de Catilina empregados no caso nominativo, Goettems (1993, p. 119) chega aos seguintes pares:

Coluna 1

homines

animus

imperium

homines et di

ingenium

gloria

memoria $\rightarrow$ longa

uirtus $\rightarrow$ clara aeternaque
X

Coluna 2

X

X

X

X

X

X

X

X cetera animalia

corpus

seruitium

beluae

uis (corporis)

silentium

uita $\rightarrow$ breuis

diuitiarum et formae gloria $\rightarrow$

fluxa atque fragilis (Bel. Cat. 1,

O prólogo da Guerra Jugurtina, por sua vez, aproveita a antítese entre animus e corpus nas 
passagens Bel. Iug. I, 2-4 dux atque imperator vitae mortalium animus est [...] Sin captus pravis cupidinibus ad inertiam et voluptates corporis pessum datus est [...] (“o chefe e o senhor da vida humana é o ânimo [...] mas, se capturado pelos maus desejos, é rebaixado à inércia e às vontades do corpo") e ainda Bel. Iug. II, 1 Nam uti genus hominum compositum ex corpore et anima est, ita res cuncta studiaque omnia nostra corporis alia, alia animi naturam secuntur ("Pois, como o gênero humano é composto de corpo e alma, assim também todas as nossas ações e desejos seguem alguns a natureza do corpo e outros, da alma”). Desenvolve, ainda, essa antítese, revelando que, das coisas relacionadas ao corpo - a beleza, as riquezas e a força física - nada ou muito pouco resta, quando daquelas relacionadas ao ânimo o caminho é a imortalidade ${ }^{45}$.

De boa índole são aqueles que seguem os imperativos do espírito - a saber, a probidade, a industriosidade e as demais qualidades boas - e são dignos da glória; de índole depravada, por sua vez, são aqueles que seguem os imperativos do corpo - isto é, os prazeres, a afeição ao luxo e a moleza $^{46}$. Disso segue-se que, em relação às magistraturas, os de má índole as obtêm pela torpeza, e os de boa índole as obtêm honestamente ou delas honestamente se afastam ${ }^{47}$.

Ao enunciar as virtudes necessárias para aconselhar, a persona do orador, nas Ep. ad Caes., tal como em Salústio (Bel. Cat. 1, 1-4; Bel. Iug. I, 2-4; II, 1), soma a experiência política à boa índole, necessária para o discernimento do que é bom e do que é ruim, em duas passagens - a primeira integra o exórdio da Ep. ad Caes. II e a segunda, a confirmação nessa mesma epístola:

Ep. ad Caes. II 1, 3 Sed mihi studium fuit adulescentulo rem publicam capessere: atque in

45 Bel. Iug. II, 3 Postremo corporis et fortunae bonorum ut initium sic finis est, omniaque orta occidunt et aucta senescunt: animus incorruptus, aeternus, rector humani generis agit atque habet cuncta neque ipse habetur.

46 Bel. Iug. I, 3 Qui ubi ad gloriam virtutis via grassatur, abunde pollens potensque et clarus est neque fortuna eget, quippe quae probitatem, industriam aliasque artis bonas neque dare neque eripere cuiquam potest; Bel. Iug. II, 4 Quo magis pravitas eorum admiranda est, qui, dediti corporis gaudiis, per luxum et ignaviam aetatem agunt, ceterum ingenium, quo neque melius neque amplius aliud in natura mortalium est, incultu atque socordia torpescere sinunt.

47 Bel. Iug. III, 1 Verum ex iis magistratus et imperia, postremo omnis cura rerum publicarum minime mihi hac tempestate cupienda videntur, quoniam neque virtuti honor datur neque illi, quibus per fraudem iis fuit uti, tuti aut eo magis honesti sunt; Bel. Iug. IV, 3 Atque ego credo fore qui, quia decrevi procul a re publica aetatem agere, tanto tamque utili labori meo nomen inertiae imponant, certe quibus maxima industria videtur salutare plebem et conviviis gratiam quaerere. 
ea cognoscenda multam, magnamque curam habui: non ita, uti magistratum modo caperem, quem multi malis artibus adepti erant; sed etiam uti rempublicam domi militiaeque, quantumque armis, uiris, opulentia posset, cognitam haberem.

Ep. ad Caes. II 1, 3. "Mas desde jovem meu interesse foi zelar pela república, e fiz um grande esforço em conhecê-la não apenas para exercer a magistratura, que muitos alcançaram de maneira ilícita, e sim para que tivesse o conhecimento da república na paz e na guerra, e de quanto podia a opulência de armas e de homens”.

Ep. ad Caes. II 12, 3 Volo ego consilium meum prudens maxumeque usui esse. Nam ubicumque tibi res prospere cedet, ibi mihi bona fama eueniet. 4. Si me illa magis cupido exercet, uti quocumque modo quam primum respublica adiuuetur.

Ep. ad Caes. II 12, 3 “Desejo que meu conselho seja prudente e, sobretudo, útil, porque onde te acontecer algo promissor, daí virá minha boa fama. 4. Mas o que mais me persegue é o desejo de que salves a república de qualquer maneira e o quanto antes”.

Com efeito, o discurso daqueles que sustentam um parecer deve ter a utilidade (finem utilitatis) como meta (Rhet. ad Her. III. 3), a qual é dividida em duas partes: a parte segura (tutam) e a honesta (honestam). Divididas em tópicos, as partes segura e honesta desempenham, no discurso, o papel de reforçar a exortação ou o conselho por meio do movimento das afecções (cf. Cíc. De or. II 82, 337). Para cumprir tal meta, a acomodação do discurso às regras da invenção solicita o reconhecimento do gênero da causa - honesta, torpe, dúbia e humilde (Rhet. ad Her. I. 5) - já no exórdio. Espera-se, dessa maneira, cumprir a função, específica dessa parte do discurso, de tornar o ouvinte dócil, benevolente e atento.

A deduzir do que diz Cícero (De Off. I 1,1; 2,4 e De Or. III 16, 59), a noção de dever é comum ao indivíduo agindo em situações pessoais e tratando de questões públicas, o que inclui 
tanto a ação política quanto a atividade do orador. Nesse sentido, qualquer decisão a ser tomada com vistas ao cumprimento do dever considera, especificamente, duas virtudes - a honestidade (honestas), a utilidade (rationem utilitatis) - e o possível conflito entre essas duas virtudes (cum pugnare videtur cum honesto id, quod videtur esse utile; “uma vez que parece lutar com o honesto aquilo que parece ser útil”) (De Off. I 3,9), uma vez que, segundo Cícero (De Off. I 4,11), é da natureza humana discernir as causas das coisas, comparar e relacionar semelhanças a fim de preparar-se para a vida.

As partes da honestidade são quatro - a sabedoria (sapientia), a ordem (ordo), a constância (constantia) e a moderação (moderatio) (De Off. I 5,17 - 52,151), as quais evitam as decisões erradas ou desnecessárias e levam o homem a agir com justiça. A utilidade, por sua vez, considera o que diz respeito à preservação da vida (o trabalho, o acordo entre os humanos, a boa reputação, a benevolência, a glória e a parcimônia) e repudia o que a prejudica ou atrapalha, visando à vida em comunidade (De Off. II 3,11 - 25,90). Por fim, o conflito entre essas duas virtudes deve ser considerado para que não sejam tomadas decisões que pareçam úteis ou honestas, sem o serem, a fim de que seja mantida a noção de cumprimento do dever (De Off. III 2,7 - 9,39).

Portanto, a menção ao empenho (studium), ao cuidado (curam) e ao conhecimento da administração da república (ut rempublicam [...] cognitam haberem) (Ep. ad Caes. II 1, 3), bem como a intenção de aconselhar prudente e utilmente (Ep. ad Caes. II 12, 4 Volo ego consilium meum prudens maxumeque usui esse) estabelecem a causa do discurso como sendo útil e honesta. Ao mesmo tempo, a honestidade e a utilidade direcionam os elementos da invenção conforme as regras do gênero deliberativo (de cujas relações com as Ep. ad Caes. tratarei no segundo capítulo) e constituem virtudes essenciais para conferir ao orador a autoridade no aconselhamento.

Além de conferir autoridade ao orador no discurso, a virtude da honestidade possui função decisiva no que poderia ser descrito como um tipo de literatura escolar. Ao que indica o corpus de textos escolares analisados por Teresa Morgan (1998, pp. 121-125), temas filosóficos envolvendo a 
honestidade, a sabedoria, a amizade, a velhice, a prosperidade, o favor divino e a sorte dominavam todo tipo de exercício - dos exercícios de alfabetização até os mais elaborados - na forma de sententiae, usus e pequenas narrativas de exemplos ilustres constantemente reciclados -, os quais são frequentes em papiros das origens geográficas as mais distintas. Tanto eles confirmam a máxima de Quintiliano segundo a qual a moralidade pode ser aprendida (Inst. Or. I 1,36; XII 2,15; XII 2,29-30) quanto estabelecem quais virtudes eram aceitas entre os cidadãos gregos ou entre os romanos. Formam, assim, uma espécie de herança cultural ao mesmo tempo diversificada e suficientemente imprecisa para atender a qualquer tipo de situação (cp. Morgan, 1998, p. 126).

Diferentemente da segunda epístola, o orador apela para a uirtus no exórdio da primeira Ep. ad Caes., tanto para construir a sua autoridade quanto para influenciar o ânimo da audiência. Para tanto, lembra que a uirtus deva ser preservada acima de tudo (I 1,3), porque predispõe o homem poderoso a não se deixar levar pelos excessos do poder absoluto (I 1,4), a tomar as decisões certas (I 1,5) e a promover a paz por meio do exercício da clemência (I 1,5-8). À uirtus o orador soma a boa fortuna para fazer o elogio a César e assim poder justificar a utilidade de suas ações. Nesse sentido, suas virtudes são amplificadas (e.g. I 1,7 bellum aliorum pace mollius gessisti) para atribuir grandeza à matéria da obra (cf. Menandro, o rétor, Tratado II, 368 et seq.). Portanto, mesmo usando expedientes distintos, ambas as epístolas tornam o aconselhamento útil e honesto.

Na Conjuração de Catilina (2, 5 et seq.), o historiador menciona a degeneração moral dos indivíduos, sem a qual não seria possível o estabelecimento de um modelo de ação política em situações de tumulto. A comparação, novamente antitética, entre o passado e o presente, mais do que ratificar a constituição civil por meio do reforço das virtudes do cidadão (o que também ocorre em Bel. Iug. IV.5-9), propõe simultaneamente o abandono do sensível, a superação da finitude e a valorização da memória e do registro (Goettems, 1993, pp. 120;122). Analisando os conceitos do exórdio da Conjuração de Catilina, Goettems (1993, p. 119-121) chega aos seguintes pares: 


\begin{tabular}{ccc}
\multicolumn{1}{l}{$\begin{array}{l}\text { labor } \\
\text { continentia }\end{array}$} & $\mathrm{X}$ & socordia atque desidia \\
lequitas & $\mathrm{X}$ & superbia \\
pudor & $\mathrm{X}$ & audacia \\
abstinentia & $\mathrm{X}$ & largitio \\
uirtus & $\mathrm{X}$ & avaritia \\
otium & $\mathrm{X}$ & agrumcolere/enare servilia \\
& & officia (Bel. Cat. 2,5; 3,3; 4,1)
\end{tabular}

Tal como em Bel. Cat. 2,5; 3,3; 4,1, as duas Ep. ad Caes. apontam a degeneração dos costumes dos cidadãos para opor passado e presente, e assim tornarem o aconselhamento útil e honesto, em três passagens:

Ep. ad Caes. I 7,4 nam saepe ego quom animo meo reputans quibus quisque rebus clari uiri magnitudinem inuenissent quaeque res populos nationesue magnis auctibus auxissent, ac deinde quibus causis amplissima regna et imperia conruissent, eadem semper bona atque mala reperiebam, omnesque uictores diuitias contempsisse et uictos cupiuisse.

Ep. ad Caes. I 7,4 "Refletindo muitas vezes comigo mesmo sobre aquilo que pôde proporcionar glória aos homens ilustres e aumentar as riquezas de povos ou nações, e depois sobre as causas que destruíram impérios e reinos enormes, percebia que as causas da ventura e da ruína eram sempre as mesmas: todos os vencedores haviam desprezado as riquezas, enquanto os vencidos, haviam-nas desejado”. 
Ep. ad Caes. I 8,1 Nam domum aut uillam exstruere, eamque signis aulaeis aliisque operibus exornare et omnia potius quam semet uisendum efficere, id est non diuitias decori habere, sed ipsum illis flagitio esse. 2. porro ei, quibus bis die uentrem onerare, nullam noctem sine scorto quiescere mos est, ubi animum, quem dominari decebat, seruitio oppressere, nequeicquam eo postea hebeti atque claudo pro exercito uti uolunt. 3. nam imprudentia pleraque et se praecipitat.

Ep. ad Caes. I 8,1 “Com efeito, construir casas e fazendas, orná-las com estátuas, tapetes e outras obras de arte para chamar mais a atenção do que elas fazem por si mesmas não é ter riquezas por distinção, e sim tê-las por depravação. 2. Considero que aqueles que costumam encher o estômago duas vezes ao dia e não passar uma só noite sem a companhia de meretrizes, sendo assim escravos do espírito que deveriam dominar, mais tarde, tendo-o enfraquecido e vacilante, debalde quererão exercitá-lo. 3. Na verdade, é a imprudência que muitas vezes destrói a si mesma”.

Ep. ad Caes. II 5,1 In duas partes ego ciuitatem diuisam arbitror, sicut a maioribus accepi, in Patres et plebem. Antea in patribus summa auctoritas erat, uis multo maxuma in plebe 2. Itaque saepius in ciuitate secessio fuit, semperque nobilitatis opes deminutae sunt, et ius populi amplificatum. 3. Sed plebs eo libere agitabat, quia nullius potentia super leges erat; neque diuitiis, aut superbia, sed bona fama factisque fortibus nobilis ignobilem anteibat: humillumus quisque in aruis aut in militia nullius honestae rei egens, satis sibi, satisque patriae erat. 4. Sed, ubi eos paulatim expulsos agris inertia atque inopia incertas domos habere subegit, coepere alienas opes petere, libertatem suam cum republica uenalem habere. 5. Ita paulatim populus qui dominus erat, et cunctis gentibus imperitabat, dilapsus est: et, pro communi imperio priuatim sibi quisque seruitutem peperit. 6. Haec igitur multitudo primum malis moribus inbuta, deinde in artis uitasque uarias dispalata, 
nullo modo inter se congruens, parum mihi quidem idonea uidetur ad capessendam rem publicam.

Ep. ad Caes. II 5,1 “Em duas partes eu julgo que a cidade está dividida - de acordo com o que tive conhecimento dos antigos: em patrícios e plebe. Antigamente, aos patrícios pertencia o sumo poder, e à plebe uma força muito maior. 2. Foi assim que muitas e muitas vezes houve conflito na cidade, e sempre a força da nobreza foi diminuída e o direito do povo, ampliado. 3. Mas a plebe até ali vivia livremente, porque o poder de ninguém estava acima das leis, nem o nobre se antepunha ao ignóbil pelas riquezas ou soberba, mas pela boa fama de suas ações: o homem mais humilde não era privado, nas lavouras ou na milícia, de nenhuma coisa honesta - era o bastante para si e para a pátria. 4. Mas quando a inércia e a pobreza paulatinamente obrigaram-nos, expulsos dos campos, a ter morada incerta, eles começaram a reivindicar outros haveres e a tratar sua liberdade, e com ela a república, como algo venal. 6. Por consequência essa multidão, primeiramente imbuída de maus hábitos e depois lançada a diferentes formas de atividade e de vida, de modo algum de acordo consigo, parece-me decerto pouco idônea para administrar a república”.

Entendo, a partir desses trechos, que a autoridade do orador é constituída por três expedientes:

a) a enunciação em primeira pessoa (Ep. ad Caes. I 1,10 ac mihi sic uidetur; I 7,4. nam saepe ego quom animo meo reputans; I VIII,2. porro; II V. 1. In duas partes ego ciuitatem diuisam arbitror);

b) o uso da antítese na oposição entre labor e desidia (Ep. ad Caes. I 7,5 omissis pecuniae et corporis gaudiis, [...] in labore patientia bonisque praeceptis et factis fortibus exercitando), entre imperium e seruitium (Ep. ad Caes. I 8,2 porro ei, quibus bis die uentrem onerare, 
nullam noctem sine scorto quiescere mos est, ubi animum, quem dominari decebat, seruitio oppressere) e entre passado e presente (Ep. ad Caes. II 5,1-6);

c) a menção à experiência política (Ep. ad Caes. I 7,4. nam saepe ego quom animo meo reputans [...] quaeque res populos nationesue magnis auctibus auxissent, ac deinde quibus causis amplissima regna et imperia conruissent; II 5,1 In duas partes ego ciuitatem diuisam arbitror).

Nos dois últimos expedientes, imitam-se os mesmos conceitos que norteiam a obra salustiana - a saber, a degeneração dos costumes dos cidadãos para opor o passado ao presente para assim explicar tanto a origem das dissensões entre os humanos, como ainda aconselhar que soluções podem ser dadas aos problemas do presente, as quais são o alvo das ações do destinatário do discurso.

Como evidência disso, menciono as coincidências entre as passagens Ep. ad Caes. I 8.2 e Bel. Cat. 2,7-9, nas quais a antítese é demonstrada pelo par animus x corpus ${ }^{48}$, e entre Ep. ad Caes. II 5.3-5 e Bel. Cat. 9, 1-2; 11,1-4; 12,4-5, nas quais a antítese é demonstrada pelo par passado x presente $^{49}$. Nessas passagens, a autoridade no aconselhamento é obtida pela menção à necessidade

48 Ep. ad Caes. I 8.2 Porro ii, quibus bis die uentrem onerare, nullam noctem sine scorto quiescere, mos est; ubi animum, quem dominari decebat, seruitio obpressere, nequicquam eo postea hebeti atque claudo, pro exercito uti uolunt: nam imprudentia pleraque et se praecipitant. ср. Bel. Cat. 2,7-9 Sed multi mortales, dediti ventri atque somno, indocti incultique vitam sicuti peregrinantes transiere; quibus profecto contra naturam corpus voluptati, anima oneri fuit.

49 Ep. ad Caes. II V. 2. Itaque saepius in ciuitate secessio fuit, semperque nobilitatis opes deminutae sunt et ius populi amplificatum. 3. Sed plebs eo libere agitabat, quia nullius potentia super leges erat; neque diuitiis, aut superbia, sed bona fama factisque fortibus nobilis ignobilem anteibat: humillumus quisque in aruis aut in militia nullius honestae rei egens satis sibi satisque patriae erat. 4. Sed ubi eos paulatim expulsos agris inertia atque inopia incertas domos habere subegit, coepere alienas opes petere, libertatem suam cum republica uenalem habere. 5. Ita paulatim populus qui dominus erat, et cunctis gentibus imperitabat, dilapsus est et pro communi imperio, priuatim sibi quisque seruitutem peperit. cp. Bel. Cat. 9, 1-2 Igitur domi militiaeque boni mores colebantur; concordia maxuma, minuma avaritia erat; ius bonumque apud eos non legibus magis quam natura valebat. Iurgia, discordias, simultates cum hostibus exercebant, cives cum civibus de virtute certabant. In suppliciis deorum magnifici, domi parci, in amicos fideles erant; Bel. Cat. 11,1-4 Sed primo magis ambitio quam avaritia animos hominum exercebat, quod tamen vitium propius virtutem erat. Nam gloriam, honorem, imperium bonus et ignavus aeque sibi exoptant; sed ille vera via nititur, huic quia bonae artes desunt, dolis atque fallaciis contendit. Avaritia pecuniae studium habet, quam nemo sapiens concupivit: ea quasi venenis malis inbuta corpus animumque virilem effeminat, semper infinita, insatiabilis est, neque copia neque inopia minuitur; Bel. Cat. 12,4-5 Verum illi delubra deorum pietate, domos suas gloria decorabant neque victis quicquam praeter iniuriae licentiam eripiebant. At hi contra, ignavissumi homines, per summum scelus omnia ea sociis adimere, quae fortissumi viri victores reliquerant: proinde quasi iniuriam facere 
de contenção dos afetos e apetites (a fim de identificar a honestidade que o homem político deve demonstrar no serviço à república) a partir dos exemplos opostos, i.e., os amantes do prazer e do luxo; à primitiva austeridade dos romanos, que regulava e justificava as benesses da república romana e, por fim, à explicação do poder do dinheiro e da corrupção da juventude no desencadeamento de conflitos civis. As duas Ep. ad Caes., portanto, cumprem os requisitos do discurso deliberativo, a saber, a utilitas e a honestas (cf. Cícero, De or. II 81.333-334), por meio da imitação de Salústio na construção da persona responsável pelo aconselhamento.

A construção discursiva dessa persona oratória obedece, portanto, a um saber técnico que reúne noções da filosofia, da história e da retórica, aliadas às virtudes que o orador enuncia para aconselhar. Nesse sentido, ela não contrasta com as habilidades do orador que Cícero fornece no passo seguinte:

De Or. III 31, 125 rerum enim copia verborum copiam gignit; et, si est honestas in rebus ipsis, de quibus dicitur, exsistit ex re naturalis quidam splendor in verbis. Sit modo is, qui dicet aut scribet, institutus liberaliter educatione doctrinaque puerili et flagret studio et a natura adiuvetur et in universorum generum infinitis disceptationibus exercitatus ornatissimos scriptores oratoresque ad cognoscendum imitandumque delegerit, ne ille haud sane, quem ad modum verba struat et inluminet, a magistris istis requiret; ita facile in rerum abundantia ad orationis ornamenta sine duce natura ipsa, si modo est exercitata, delabitur.

De Or. III 31, 125 “Portanto, a variedade de assuntos gera a variedade de palavras; e, se nos próprios assuntos existe honestidade, a partir deles surge um certo esplendor natural nas palavras. Que assim seja aquele que discursa ou escreve, disciplinado livremente desde menino; que seja tomado de boa vontade e seja ajudado pela natureza; que, versado nas infinitas discussões de todos os tipos, tenha se dedicado a conhecer e a imitar os mais 
refinados escritores e oradores a fim de não requerer mestres, e sim dispor e iluminar as palavras: assim é que a própria natureza, se desse modo for exercitada, facilmente será submetida, sem restrições, à abundância de temas e mesmo aos ornamentos do discurso”.

Essas habilidades são retomadas na definição de orador dada por Quintiliano logo no proêmio das Instituições Oratórias (I, 9-10). O orador, nas Ep. ad Caes., é tido não apenas como excelente na vida privada, mas ainda experiente nos assuntos relativos à república. Assim, à asserção teórica de Quintiliano (ibid.),

Inst. Or. I 1,9 Oratorem autem instituimus illum perfectum, qui esse nisi vir bonus non potest, ideoque non dicendi modo eximiam in eo facultatem sed omnis animi virtutes exigimus. 10. Neque enim hoc concesserim, rationem rectae honestaeque vitae, ut quidam putaverunt, ad philosophos relegandam, cum vir ille vere civilis et publicarum privatarumque rerum administrationi accommodatus, qui regere consiliis urbes, fundare legibus, emendare iudiciis possit, non alius sit profecto quam orator.

Inst. Or. I, 9-10 “Instituímos como orador perfeito aquele que não pode ser nada aquém de um bom homem, e por isso exigimos nele não apenas a exímia faculdade de discursar, mas também todas as virtudes do ânimo. Não terei concedido aos filósofos, como alguns julgaram, o caminho da vida reta e honesta, estando aquele homem ajustado à administração dos assuntos públicos e privados: com certeza não é outro que pode governar as cidades, fundá-las sob as leis e corrigi-las com a justiça senão o orador”.

respondem, como prática, as duas Ep. ad Caes. nas passagens I 7,4; I 8,2; II 1,3 e II 12,4 analisadas acima. Isso porque, nelas, a persona oratória menciona sua experiência política, o aprimoramento do espírito e o valor dado ao conselho honesto e útil, o que não contrasta com a definição de orador 
dada por Quintiliano. Nesse sentido, as Ep. ad Caes. aproximam a retórica das demais artes liberais, sendo igualmente definida por Cícero e por Quintiliano como uma ciência universal, omnium rerum scientia (cf. Inst. Or. II 21, 14 Possem hic Ciceronis respondere uerbis, apud quem hoc inuenio: “mea quidem sententia nemo esse poterit omni laude cumulatus orator nisi erit omnium rerum magnarum atque artium scientiam consecutus": sed mihi satis est eius esse oratorem; "Eu poderia aqui responder com as palavras de Cícero, no qual encontro isso: “na minha opinião ninguém poderá ser cumulado, com toda a honra, com o nome de orador se não for apoiado pela ciência de todos os assuntos grandiosos e das artes: mas para mim basta que ele seja orador”).

O apelo às virtudes e práticas individuais, de um lado, e a orientação do conselho para o que é honesto e útil, de outro, confirmam, nas Ep. ad Caes., a tendência de se vincular o caráter do orador à eficiência do discurso, expressa na definição do orador por Catão - uir bonus dicendi peritus - e retomada por Quintiliano (Inst. Or. XII 1,1; cp. III 8,12-13). Por uir bonus, entende-se o homem honesto e de vida correta, o que lhe permite falar com justiça, coragem e bom senso (Inst. Or. XII 2,5 - XII 16,11 apud Morgan, 1998, p. 227); por dicendi peritus, entende-se a destreza demonstrada pelo orador em dizer não apenas o que é bom, útil e apropriado para cada causa, mas orientar a própria arte oratória para o bem (ibid.). A retidão moral e a proficiência em discursar irmanam-se e são interdependentes na definição de orador por Quintiliano porque são dons naturais que, aprimorados pelo estudo e pelo exercício, elevam o homem acima da condição dos demais seres vivos (Inst. Or. II 20,6-7; XII 1,2-3; cp. Morgan, 1998, p. 228). É nesse sentido que o orador deve buscar constantemente o conhecimento de todos os assuntos edificantes, relacionados especialmente à filosofia, à política e à história.

As passagens I 7,4; I 8,2; II 1,3 e II 12,4 das Ep. ad Caes. contrastam ainda menos com a asserção de Cícero (De Or. II 81.333), segundo a qual a persuasão ou a dissuasão acerca de uma questão é tarefa para uma pessoa importante pela sabedoria, pela honestidade e pela expressividade: a sabedoria confere a destreza do pensamento; a honestidade, a prova pela autoridade e a expressividade, a persuasão pelo discurso. Ademais, elas respondem, como prática, à divisão de 
tópicos para o aconselhamento útil e honesto, pois, como afirma Cícero (De Or. II 82.335), aquele que defende a utilidade deve enumerar as vantagens da paz, das riquezas ou do poder, quando aquele que defende a honestidade deve enumerar os exemplos dos antepassados, o louvor e a dignidade provenientes das ações honestas. Por fim, elas respondem ainda aos preceitos para aquele que dá um conselho sobre a atividade política (De Or. II 82.337), isto é, conhecer política, discursar com verossimilhança e empregar um gênero de discurso mais elevado e mais ilustre.

A imitação de Salústio nas Ep. ad Caes., com vistas à construção da persona do orador (que se assenta no conhecimento da política, de um lado, e no direcionamento da virtude para aconselhar sobre coisas honestas e úteis, de outro), segue a instrução de Quintiliano para a formação do orador como homem público e como indivíduo (Inst. Or. I, 9-10). Do orador são exigidas todas as virtudes do ânimo e a faculdade de bem falar para atuar na vida pública (Inst. Or., ibid., regere consiliis urbes, fundare legibus, emendare iudiciis possit), e por isso mesmo ele necessita da instrução: graças a ela a retórica é uma arte, não um dom natural (De Or. I 4,14-17; I 35,164; Inst. Or. II 14,5; Lausberg, 1994, §§ 28-45) e é por meio dela que os homens aprendem a conviver politicamente (De rep. I, 16, 25; V, 4, 6; Lepore, 1954, pp. 52-54; Morgan, 1998, pp. 228-229).

As passagens das Ep. ad Caes. I 7,4; I 8,2; II 1,3 e II 12,4 reforçam o propósito de tornar o destinatário dócil pela matéria (porque essa diz respeito à república) e pela menção à experiência política (cf. Rhet. ad Her. I. 7-8) - nesse caso, a do orador. A partir de agora, entretanto, tratarei de como são constituídas as virtudes e como é referida a experiência política da personagem a quem o discurso é dirigido.

\section{Commouere}

A primeira parte deste capítulo procurou explicitar os elementos que constroem a persona do orador a partir da comparação entre essa e o que Salústio diz de si mesmo em suas duas monografias, a fim de demonstrar como a imitação de Salústio resultou, na verdade, em um ideal de orador (Quint. Inst. Or. I 1,18-28; I 10,4). O objetivo desta segunda parte é demonstrar como a 
construção discursiva do destinatário das Ep. ad Caes. resulta, na verdade, no ideal de governante, no que dista significativamente das monografias salustianas.

Já de imediato há um contraste de referência para compor as virtudes de César pois, enquanto elas são confrontadas às de Catão na Guerra de Catilina, na Ep. ad Caes. I, César é confrontado a Cneu Pompeu.

Salústio compara César e Catão em Bel. Cat. 53.6, lembrando-se de que ambos são distintos pela virtude e pelos costumes (Sed memoria mea ingenti virtute, divorsis moribus fuere viri duo, $M$. Cato et C. Caesar). Cabe salientar que a expressão divorsis moribus serve tanto para contrastar as duas personagens entre si, como ainda contrastá-las aos demais romanos, rendidos ao luxo e à riqueza de uma cidade corrompida (Bel. Cat. 53, 2), o que as coloca simultaneamente como superiores pela grandeza de espírito e pelas práticas individuais. Nesse sentido, apesar de distintas, suas virtudes são complementares (Bel. Cat. 53, 1 igitur eis genus, aetas, eloquentia prope aequalia fuere, magnitudo animi par, item gloria, sed alia alii) e juntas se opõem, na verdade, aos vícios de Catilina e de seus seguidores. Ambrósio (2002, p. 115) destaca que, enquanto César é descrito como sendo mais ativo, benevolente e misericordioso, Catão é descrito como sendo mais severo, digno e constante, ao modelo do sábio estoico. Para analisar em que diferem César e Catão, na Conjuração de Catilina (54, 1-6), Ambrósio (ibid.) chega às seguintes antíteses:

César X Catão

$\begin{array}{ccc}\text { beneficia ac munificentia } & \mathrm{X} & \text { integritas uitae } \\ \text { mansuetudo et misericordia } & \mathrm{X} & \text { seueritas, dignitas } \\ \text { dare, subleuare, ignoscere } & \mathrm{X} & \text { nihil largire } \\ \text { miseris perfugium } & \mathrm{X} & \text { malis pernicies } \\ \text { facilitas } & \mathrm{X} & \text { constantia }\end{array}$


De acordo com essas virtudes, César busca distinção pelos feitos bélicos, enquanto Catão, pela integridade e pela sabedoria (Bel. Cat. 54, 3-4 Postremo Caesar [...] sibi magnum imperium, exercitum, bellum novum exoptabat, ubi virtus enitescere posset. At Catoni studium modestiae, decoris, sed maxume severitatis erat [...]).

Os feitos bélicos são também importantes para César nas Ep. ad Caes, mas conferem-lhe virtudes diferentes daquelas que figuram na monografia de Salústio. A menção direta às virtudes de César, nas Ep. ad Caes, aparece nas seguintes passagens:

I 1.6 cum ipse bonus atque strenuus sis

I 1.6 "sendo, tu mesmo, bom e diligente”

I 6.1 ista egregia tua fama

I 6.1. "tua fama singular"

II 1.4 tuam dignitatem

II 1.4 "tua dignidade”

II 1.5 semper tibi maiorem in aduorsis, quam in secundis rebus animum esse

II 1.5 "tua coragem é sempre maior na adversidade do que na sorte”

II 2.3 uirtute tua

II 2.3 "tua virtude” 
II 2.4 magnitudine tua

II 2.4 "tua grandeza”

II 4.3 tua dignitas

II 4.3. "tua dignidade”

II 12.5 clarissumus imperator

II 12.5 “eminentíssimo imperador”

II 13.4 fama uirtutis tuae

II 13.4 "a fama de tua virtude"

II 13.5 gloria tua

II 13.5 “tua glória”

II 13.5 quis te clarior, quis maior in terris fuerit

II 13.5 "quem terá sido mais ilustre, quem terá sido maior do que tu?”

César, portanto, figura nas Ep. ad Caes como um modelo devido a sua bondade (bonus), a sua diligência (strenuus), a sua mansidão (I 1.7 bellum aliorum pace mollius gessisti), a sua dignidade (dignitas), a sua coragem (animum), a sua virtude (uirtus), a sua grandeza (magnitudo; maior), a sua glória e a sua distinção (clarissimus; clarior). 
Com efeito, Cícero elenca, entre as virtudes relativas ao que é honesto, a bondade (uir bonus), a simplicidade (uir simplex), a coragem (fortitudo; fortis animus) e a magnamidade (animi elatio; uir magnanimus) (De Off. I 19.62; cp. De inv. II 53.159-55.168; Teão, Prog. 110). Essas virtudes se relacionam porque promovem a justiça (ibid. Nihil honestum esse potest, quod iustitia vacat) e porque desprezam as coisas humanas (De Off. I 19.61). Nesse sentido, não se relacionam à força do corpo (De Off. I 23.79) e rendem fama e glória para quem as possui (De Off. I 24.84).

Dentre elas, a magnamidade destaca-se como a virtude daqueles que são responsáveis pelos assuntos da república (De Off. I 21.73), uma vez que o homem magnânimo e corajoso se distingue pelo desprezo aos bens materiais e pela realização de ações úteis, relacionadas à república (De Off. I 20.66; 22.74; 23.80; 24.83). Ademais, é a virtude daqueles que põem a si mesmos em risco em prol da comunidade (De Off. I 24.84) e, por afastar a volúpia e a ganância, orienta o homem a agir com sabedoria e firmeza (De Off. I 20.68).

Cícero, no De republica, reúne essas virtudes para formular o conceito de princeps, ou primeiro cidadão. Antes dele, Platão afirmara, na República, a proeminência do filósofo sobre o político, favorecendo àquele como representante do poder por ser sábio, no que foi seguido pelos estoicos. Aristóteles, todavia, pleiteia na Política (1278b 38), a partir da excelência do homem, um governante que atue como moderador do interesse dos governados (Grimal, 1985, p. 243). Retomando o debate sobre o governante ideal, Cícero define o princeps como sendo, sobretudo, sábio, virtuoso e que, tendo autoridade de julgar e organizar as questões públicas, identifica-se com um princípio ordenador e imperante (Grimal, 1985, p. 246; Lepore, 1954, pp. 82; 88), devendo por isso ser reconhecido como optimus ciues, o melhor cidadão.

De fato, o cerne da discussão ciceroniana é a virtude (uirtus; cp. Ep. ad Caes. II 2.3 uirtute tua) como exercício prático (De rep. I 2.2 Nec vero habere virtutem satis est quasi artem aliquam nisi utare; "com efeito, possuir virtude como um saber qualquer não é o bastante se ela não tiver uso”), retomando a oposição entre a vida contemplativa e a vida prática. Demonstra, nisso, a 
superioridade do político em relação ao filósofo, já que ele exerce a virtude principalmente nos assuntos da república ${ }^{50 .}$ Enquanto o filósofo trata, em âmbito teórico, da justiça e da honestidade, o político necessariamente as confirma ao atuar na proclamação e na observação das leis ${ }^{51}$, regulando a vida social a partir delas e de seus costumes ${ }^{52}$. Desse modo, a uirtus torna-se fundamental para a existência de qualquer república (De rep. I 34.52), pois modera os interesses dos homens a partir da prática da justiça e do consenso quanto ao bem comum, e impede o desacordo que leva tanto à arbitrariedade do tirano quanto ao desregulamento da massa popular ${ }^{53}$.

Cícero quer dizer, como resultado disso, que a melhor república é aquela que se assemelha a um só homem (Lepore, 1954, pp. 87-88, citando Aristóteles, Pol., II 1261a 15); sendo ele virtuoso, também virtuosa será a república: talis est quaeque res publica qualis eius natura aut uoluntas qui illam regit; “a república é tal qual a natureza ou a vontade daquele que a governa” (De rep., I XXXI, 47 [ed. de Keyes]). A virtude exercida nos assuntos de interesse público e a sabedoria que permite a escolha do bem comum são as justificativas da existência do princeps.

Assim, o termo princeps assume um significado amplo nas obras de Cícero. No De oratore, por exemplo, o termo aparece indicando os que se sobressaem como generais, juristas e filósofos ${ }^{54}$, e denomina ainda aqueles que se sobressaem na oratória e na eloquência. Assim, lê-se (grifo meu),

De or., III 63 ex iliis autem, quae remanent, ea philosophia quae suscepit patrocinium uoluptatis, etsi cui uera uideatur, procul abest ab eo uiro, quem quaerimus, et quem

50 De rep. I 2.2 usus autem eius est maximus ciuitatis gubernatio et earum ipsarum rerum, quas isti in angulis personant, reapse, non oratione perfectio.

51 Ibid., nihil enim dicitur a philosophis, quod quidem recte honesteque dicatur, quod $<$ non $>$ ab iis partum confirmatumque sit, a quibus ciuitatibus iura discripta sunt.

52 Ibid., unde enim pietas aut a quibus religio? unde ius aut gentium aut hoc ipsum ciuile quos dicitur? unde iustitia, fides, aequitas? unde pudor, continentia, fuga turpi $<$ tu $>$ dinis, adpetentia laudis et honestatis? unde in laboribus et periculis fortitudo? nemque ad iis, qui haec disciplinis informata alia moribus confirmarunt, sanxerunt autem alia legibus.

53 Ibid., Qui si unus satis omnia consequi posset, nihil opus esset pluribus; si uniuersi uidere optimum et in eo consentire possent, nemo delectos principes quaereret. Difficultas ineundi consilii rem a rege ad plures, error et temeritas populorum a multitudine ad paucos transtulit.

54 Lepore, 1954, pp. 48-49; De or. I 21, 98; I 22, 104; I 23, 105; I 49, 216; II 13, 55; II 14, 58; III 7, 28; III 16, 59; III 16, 60; III 32, 129; III 44, 173. 


\section{auctorem publici concilii et regendae ciuitatis ducem et sententiae atque eloquentiae}

principem in senatu, in populo, in causis publicis esse uolumus.

De or., III 63 “mas entre as demais coisas, a filosofia, que suscita o apoio do prazer, ainda que pareça verdade a alguém, está distante do homem que procuramos, e que desejamos seja uma autoridade nas decisões públicas, o membro mais importante na administração da república e o primeiro nas sentenças e nos discursos no senado, entre o povo, nas decisões públicas”.

O princeps não é apenas aquele que possui primazia nas iniciativas políticas - auctorem publici consilii et regendae ciuitatis ducem - mas também aquele que exercita por meio do pensar e do bem falar a sua sapientia (Lepore, 1954, p. 52) ${ }^{55}$, depositando em si mesmo, por meio da atividade oratória e da eloquência, a uirtus (Lepore, 1954, p. 54). Encarna, assim, um uir bonus dicendi peritus (ibid.). Já no De re publica, ao lado da sua proeminência de iniciativa, da sua função de rector et moderator rei publicae e da atribuição de optimus ciues, o princeps é também um princípio motor, que se identifica com a força divina que anima o homem virtuoso:

De rep. VI 8, 26 Deum te igitur scito esse, siquidem est deus, qui uiget, qui sentit, qui meminit, qui prouidet, qui tam regit et moderatur et mouet id corpus, cui praepositus est, quam hunc mundum ille princeps deus; et ut mundum ex quadam parte mortalem ipse deus aeternus, sic fragile corpus animus sempiternus mouet.

De rep. VI 8, 26 “Deverás saber que tu és um deus, visto que um deus é aquele que possui vigor em seus atos, que possui sentimento, que possui memória, que se acautela, tão senhor de si mesmo que tanto é movido quanto move o próprio corpo, ao qual se impõe da mesma forma que aquele deus-governante rege este mundo; e tal como o mesmo deus eterno, de 
alguma parte, dirige o mundo mortal, assim também a alma sempiterna ao corpo frágil”.

Integrado a um princípio motor do mundo, o princeps identifica-se com a figura do iustus, fundamentando seu papel de moderador na medida em que seus critérios, conhecidos e aceitos por todos, respeitam as leis, fundamentandas num direito natural que foge às convenções sociais e estão ligadas à própria natureza: Est quidem uera lex recta actio naturae congruens, diffusa in omnis, constans, sempiterna, quae uocet ad officium iubendo, uetando a fraude deterreat; "a verdadeira lei é uma ação congruente com a natureza, difundida em todos, sempiterna, que, exortando, chame ao dever e, vetando, afaste da fraude” (De rep. III, fr. 6). Por tais características, a figura do princeps é a única capaz de conservar a cidade:

(De rep. II, XXIX, 51 [ed. de Keyes] grifo meu) sit huic oppositus alter, bonus et sapiens et peritus utilitatis dignitatisque ciuilis, quasi tutor et procurator rei publicae; sic enim appelletur quicumque erit rector et gubernator ciuitatis. quem uirum facite ut agnoscatis; iste est enim qui consilio et opera ciuitatem tueri potest [...]

(De rep. II, XXIX, 51 [ed. de Keyes] grifo meu) "seja a ele [o tirano] contraposto um outro, sábio e experiente no serviço e no cargo civil, como tutor e representante da república. Seja assim denominado aquele que seja o governante e o timoneiro da república. Dai a esse homem o devido reconhecimento, pois é ele quem pode proteger a república com bom senso e com obras”.

Maia Júnior (2002, p. 67) observa em seus comentários de tradução que a expressão tutor et procurator se aplica, o primeiro vocábulo, “ao que mantém e sustém órfãos por direito de lei” (id., ibid.), enquanto o segundo termo "aplica-se ao que foi constituído por lei vicário de direito alheio" (id., ibid.). Nestes termos, o princeps representa fielmente o interesse de todos, subordinando-se 
como indivíduo à república e assumindo não uma posição superior em relação aos outros cidadãos, mas detendo por autoridade, auctoritas, a primazia de iniciativa num corpo político, de modo que

De rep., V 4.6 ut enim gubernatori cursus secundus, medico salus, imperatori uictoria, six huic moderatori rei publicae beata ciuium uita proposita est, ut opibus firma, copiis locuples, gloria ampla, uirtute honesta sit; huius enim operis maximi inter homines atque optimi illum esse perfectorem uolo.

De rep., V 4.6 “assim como ao timoneiro há um curso a seguir, ao médico a saúde, ao comandante a vitória, assim também a este moderador da república foi proposta a vida feliz dos cidadãos, de maneira que a república seja vigorosa nos recursos, cheia de riquezas, ampla na glória, honesta na virtude. Quero que seja, pois, ele o aperfeiçoador da maior e melhor obra entre os homens”.

Nas Ep. ad Caes., César poderia identificar-se com o princeps porque sua ação moderadora recebe a primazia no que concerne aos assuntos da república e dos cidadãos (Ep. ad Caes. I 5,1; I 6,4; II 2,4; II 12,5). Suas qualidades, portanto, são enunciadas considerando a execução de diversas tarefas, as quais, ao mesmo tempo, tanto são necessárias à república e às nações externas, quanto motivo de glória para César (I 8.7). Na Ep. ad Caes. I, esse líder é benigno, clemente (I 1.6; I 3.3; I 6.4), sábio (I 6.1-4) e valoroso (I 1.10; I. 7.1). Na Ep. ad Caes. II, somente César apresenta as virtudes necessárias para tais tarefas (II 4.3-4; 13.1-2), como o sejam a dignidade (II 1.4), a coragem e a generosidade (II 1.5-6), a virtude (II 2.3), a sabedoria, a moderação (II 2.4), a glória (II 12. 5; 13. 4-6) e porque possui uma riqueza honesta (II 13.2).

Pompeu, entretanto, figura como antítese de César, o que pode ser verificado nas seguintes passagens: 
Ep. ad Caes. I 2.2 Bellum tibi fuit, imperator, cum homine claro, magnis opibus, auido potentiae, maiore fortuna, quam sapientia. Quem secuti sunt pauci, per suam iniuriam tibi inimici; item quos adfinitas, aut alia necessitudo, traxit.

Ep. ad Caes. I 2.2 "Estiveste em conflito, imperador, contra um homem ilustre, de grande autoridade, ávido pelo poder, dotado de maior sorte do que esperteza, a quem seguiram uns poucos que se declararam inimigos teus por injúria, bem como aqueles a quem arrastou o parentesco ou alguma outra necessidade”.

Ep. ad Caes. II 3.1 Sed quoniam Cn. Pompeius, aut animi prauitate, aut quia nihil eo maluit, quam quod tibi obesset, ita lapsus est ut hostibus tela in manus iaceret.

Ep. ad Caes. II 3.1 "Uma vez que Cn. Pompeu, no entanto, ou por desatino ou por preferir algo que te obstruísse, assim se enganou, entregando as armas às mãos dos inimigos”.

Ao contrário de César, Pompeu, embora ilustre (homine claro) e de grande autoridade (magnis opibus), é, porém, ambicioso (auido potentiae), indouto (maiore fortuna, quam sapientia) e mal intencionado (animi prauitate).

Soma-se a tais deficiências a adesão obtida daqueles que nutriam inveja de César ou somavam dívidas e por isso dedicavam-se à causa de Pompeu:

Ep. ad Caes. I 2.4 cetera multitudo uolgi, more magis quam iudicio, post alius alium quasi prudentiorem secuti. 5. per idem tempus maledictis ineiquorum occupandae rei publicae in spem adducti homines, quibus omnia probro et luxuria polluta erant, concurrere in castra tua et aperte quieteis mortem rapinas, postremo omnia quae corruptus animus lubebat, minitari. 6. ex queis magna pars, ubi neque creditum condonarei neque te ciuibus sicuti hostibus uti uident, defluxere; pauci resistere quibus maius otium in castris quam Romae 
futurum erat: tanta vis creditorum impendebat. 7. sed ob easdem causas immane dictust quanti et quam multi mortales postea ad Pompeium discesserint, eoque per omne tempus belli quasi sacro atque inspoliato fano debitores usi.

Ep. ad Caes. I 2.4 "Outro número de pessoas, mais por hábitos do vulgo do que por bom senso, seguiram uns aos outros como quem segue o mais prudente. 5. Ao mesmo tempo, homens manchados por toda a luxúria e torpeza avançaram contra teus acampamentos, levados pelas calúnias de infames na esperança de tomar o poder, e ameaçavam abertamente os inocentes com a morte, roubo e tudo enfim que agrade a um espírito corrompido. 6 . Grande parte desses, percebendo que tu não perdoavas as dívidas nem vias concidadãos como inimigos, desistiu; poucos preferiram resistir nos acampamentos a permanecer em Roma, tamanha era a soma que deviam aos credores. 7. Por essas mesmas razões, é espantoso dizer quais e quantos mortais passaram para o lado de Pompeu e como se serviram dele, durante toda a guerra, como de um templo sagrado e inviolável”.

O vocabulário romano denomina o poder sedicioso de um só como a tirania (De rep. II.49). Cícero, por exemplo, ao tratar das constituições no De republica, iguala o tirano (tyrannus) ao senhor de escravos (dominus) (De rep. I.50 cur enim regem appellem Iovis optimi nomine hominem dominandi cupidum aut imperii singularis, populo oppresso dominantem, non tyrannum potius?; “mas, em nome de Júpiter Ótimo, por que devo chamar de rei um homem que deseja dominar ou ter sozinho o poder de comando, sendo o povo oprimido por um dominador, ao invés de chamá-lo de tirano?”) e mesmo aquele que assume o poder sozinho, sendo porém clemente (ibid. tam enim esse clemens tyrannus quam rex importunus potest; “um tirano pode ser tão clemente quanto um rei ser importuno”). Entende-se que, para Cícero, o tirano corresponde ao rei bem ou mal intencionado, uma vez que o poder de um só está diretamente relacionado à subordinação de cidadãos, cuja vida e morte dependem da vontade de um indivíduo (De rep. III.23 sunt enim omnes, qui in populum vitae 
necisque potestatem habent, tyranni, sed se Iovis optimi nomine malunt reges vocari). Pompeu, assim, identifica-se com o tirano, na medida em que seus partidários lutam a seu favor não por simpatia, mas por razões distintas e viciosas; ademais, enquanto as virtudes de César apontam para a solução dos problemas da república, as deficiências de seu adversário apontam para o oposto. O poder de Pompeu, portanto, é ilegítimo.

Essas deficiências do adversário de César - apresentadas na narração das duas epístolas amplificam as partes da causa honesta, obedecendo à utilidade do discurso deliberativo (Rhet. ad Her. III. 3). Dividida em tópicos, a parte honesta desempenha, no discurso, o papel de reforçar a exortação ou o conselho por meio do movimento das afecções (cf. Cíc. De or. II 337). Tais tópicos incluem a inépcia (Ep. ad Caes. I 2.2; II 3.1); a covardia, a fraqueza e a liberalidade torpe (Ep. ad Caes. I 2.5-6; II 3.2-4); a temeridade (Ep. ad Caes. I 2.4. II 3.6-7), a inércia e negligência (Ep. ad Caes. I 2.7; II 4.2) daquele cujas ações o aconselhado deve impedir.

Ademais, a acomodação do discurso às regras da invenção solicita o reconhecimento do gênero da causa já no exórdio, a fim de cumprir a função, específica dessa parte do discurso, de tornar o ouvinte dócil, benevolente e atento. Por essa razão, o exórdio de ambas as epístolas já apresenta a distinção entre o justo e o injusto visando enobrecer a matéria, valendo-se apenas dos tópicos da causa honesta. Tais tópicos incluem a prudência (Ep. ad Caes. I 1.2-3; II 2.3); a justiça (Ep. ad Caes. I 1.7-8); a coragem (Ep. ad Caes. I 1.8-9, II 1.5) e a modéstia (Ep. ad Caes. I 1.6; II 1.4) de que César deve se valer contra as ações de seu adversário.

Por fim, na peroração da Ep. ad Caes. II 13.1-8, a amplificação, amplificatio, e a personificação, prosopopeia, reforçam o caráter grandioso dos feitos de César lembrando o poder da fortuna (13.7) sobre o devir dos homens (cf. Cíc. De inv. 1, 55, 106). Com isso, a epístola se encerra com a identificação do princeps com o iustus (De rep. VI 8, 26; III, fr. 6), fundamentando, com o apoio divino, a necessidade de suas ações.

É de se notar, no entanto, que o termo princeps não figura nas Ep. ad Caes., sendo 
substituído por “comandante” ou “general”, imperator (I 2.2; II 12.1; 12.5 clarissumus imperator) ou, mais genericamente, por “alguém de máximo poder” (II 1.1 regi aut imperatori, postremo quoiquam mortali, quoius opes in excelso sunt), tal como o rei ou um imperador. Ora, as ações de César resultam de uma série de virtudes relacionadas ao poder que ele possui - ou antes, a funções que lhe são definidas - e só fazem sentido pela posição que esse líder ocupa na cidade. Nesse sentido, César possui uma competência de execução que é estranha aos demais membros da comunidade (senado e povo), já que esses detêm o poder de deliberar e de julgar. Cabe investigar, portanto, como as ações de César influem na comunidade e por que suas virtudes e ações correspondem à competência do imperador.

\section{Docere}

Dado que as virtudes de César estão relacionadas ao que é honesto (De Off. I 19.62; De inv. 58.173), e por essa razão mesma elas são mencionadas nas Ep. ad Caes., de modo a tornar o auditório benévolo, atento e dócil, é conveniente justificar a necessidade (necessitudo) das ações de César. Ao explicitar o vínculo entre as virtudes e as ações, cumpre-se a função mesma do gênero deliberativo, a saber, escolher entre o que é ou não é necessário (De inv. 58.175). Isso porque há ações que devem ser consideradas não por si mesmas, mas de acordo com os envolvidos, com a ocasião, com qual intuito e em que momento são realizadas (De inv. 58.176).

Ademais, visando cumprir a finalidade do discurso deliberativo (aconselhar sobre o que é útil e o que é honesto), o orador deve mostrar os meios pelos quais se conseguem os bens e se evitam os males quando a audiência busca a honestidade; quando a audiência busca a utilidade, por sua vez, o orador deve mostrar quais as virtudes relacionadas à manutenção e ao aumento da utilidade comum (Part. Or. 91). Assim, para acomodar o discurso à verdade e às opiniões da audiência, o orador deve apelar para o louvor, para a honra, para a fé, para a justiça e para as demais virtudes quando uma audiência humana e polida busca a dignidade; e deve tratar mesmo da vantagem, do proveito e do prazer no caso de dirigir-se a uma audiência indouta e rude (Part. Or. 
90).

A argumentação inteira das duas Ep. ad Caes. pode ser entendida como a evidência da relação entre as lições da história magistra vitae, a filosofia e a retórica. Parte do princípio ciceroniano de que o orador, como homem público, deve demonstrar completo conhecimento da constituição e do funcionamento da cidade (De rep. II.45; De Off. I.81; II.33).

Na primeira epístola, César é aconselhado sobre o que deve fazer para a conclusão da guerra (3.1 - 3.4), i.e., evitar agir com soberba, preferindo abrandar o poder com benignidade e clemência, e ser justo tanto com seus aliados quanto com seus inimigos; e o que César deve fazer para a afirmação da paz (5.1 - 8.6), i.e., reprimir os apetites da juventude, evitar que a nobreza acumule riquezas senão distintamente, impedir que as províncias e a Itália sejam alvo de sedição e evitar injustiças em relação aos veteranos de guerra. O conselho é expressamente dado nos passos seguintes:

Ep. ad Caes. I 3.1 Igitur quoniam tibi uictori de bello atque pace agitandum est, hoc tu ciuiliter deponas, illa <ut> quam iustissima et diuturna sit, de te ipso primum, quia compositurus es, quid optimum factu sit existima.

Ep. ad Caes. I 3.1 “Já que a ti, vencedor, caberá então dispor da paz e da guerra, resolve, para concluir essa como convém a um cidadão e fazer daquela a mais justa e duradoura, o que deve ser feito primeiro em relação a ti, porque tu o decidirás da melhor maneira possível”.

Ep. ad Caes. I 5,4 id ita eueniet, si sumptuum et rapinarum licentiam dempseris, non ad uetera instituta reuocans, quae iam pridem corruptis moribus ludibrio sunt; sed si suam quoique rem familiarem finem sumptuum statueris: 5.quoniam is incessit mos, ut homines adulescentuli sua atque aliena consumere, nihil libidinei atque aliis rogantibus denegare pulcherrimum putent, eam uirtutem et magnitudinem animi, pudorem atque modestiam pro 
socordia aestiment. 6. ergo animus ferox praua uia ingressus, ubi consueta non suppetunt, fertur accensus in socios modo modo in ciues, mouet composita et res nouas ueteribus + aec + conquirit. 7. quare tollendus fenerator in posterum, uti suas quisque res curemus. 8. ea uera atque simplex uia est: magistratum populo, non creditori gerere, et magnitudinem animi in addendo, non demendo rei publicae ostendere.

Ep. ad Caes. I 5,4 "Isto ocorrerá se reprimires a o excesso de luxo e de roubo, não reclamando as antigas instituições (que são, há muito tempo, por causa da corrupção dos costumes, alvo de escárnio), mas determinando a cada um o limite de despesas de acordo com seu patrimônio familiar, 5. muito embora tenha-se introduzido o costume de os jovens consumirem o que é seu e o que é alheio, e julguem extremamente belo não recusar o prazer próprio nem o que os outros lhe pedem. Isto eles julgam ser virtude e grandeza de espírito; o pudor e a modéstia julgam ser indolência. 6. É assim que um espírito feroz, ao entrar no mau caminho, sem que o satisfaça aquilo que costumava ter, vai de encontro ora aos aliados ora aos concidadãos, perturba a ordem, busca novas condições a débitos antigos. 7. Portanto, no futuro, deve-se exterminar a usura de maneira que cada um de nós cuide de nossos próprios interesses. 8. Eis a maneira mais simples e mais verdadeira para chegar a isto: que o magistrado sirva ao povo, não aos credores, e ostente a sua grandeza de espírito fazendo com que a república ganhe, não perca”.

Ep. ad Caes. I 6,3 quare capesse, per deos, rem publicam et omnia aspera, uti soles, peruade: namque aut tu mederi potes, aut omittenda est cura omnibus. 4. Neque quisquam te ad crudeles poenas aut acerba iudicia inuocat, quibus ciuitas uastatur magis quam corrigitur, sed ut prauas artis malasque libidines ab iuuentute prohibeas.

Ep. ad Caes. I 6,3 "Portanto ocupa-te - pelos deuses! - da república e, como é de teu costume, enfrenta até o fim todas as dificuldades, já que somente tu podes remediá-la, ou 
ninguém mais se atreverá a isto. 4. Não há ninguém que te peça seres cruel nos castigos ou rígido nos julgamentos, maneiras pelas quais a cidade não é reformada, mas destruída. Deves afastar da juventude as más condutas e os desejos perversos”.

Ep. ad Caes. I 7,2 igitur prouideas oportet, uti pleps, largitionibus et publico frumento corrupta habeat negotia sua, quibus ab malo publico detineatur: iuuentus probitati et industriae, non sumptibus neque diuitiis studeat. 3. id ita eueniet, si pecuniae, quae maxuma omnium pernicies est, usum atque decus dempseris.

Ep. ad Caes. I 7,2 "Deves, portanto, tomar providências para que a plebe, corrompida pelas liberalidades e pela distribuição de alimento, faça seus negócios sem contribuir para a calamidade pública, e para que a juventude empregue seu vigor na integridade e naquilo que merece esforço, e não no dispêndio e nas dívidas. 3. Isto poderá acontecer se impedires o uso e o respeito ao dinheiro, que é a maior causa da desgraça dos homens”.

Ep. ad Caes. I 8,4 ad hoc prouidendum est tibi, quonam modo Italia atque prouinciae tutiores sint: id quod factu haut obscurum est. 5. nam idem omnia uastant, suas deserendo domos, et per iniuriam alienas occupando. 6. item ne, uti adhuc, militia iniusta aut inaequalis sit, cum alii triginta, pars nullum stipendium facient. et frumentum id, quod antea praemium ignauiae fuit, per municipia et colonias illis dare conueniet, qui stipendiis emeritis domos reuerterint.

Ep. ad Caes. I 8,4 "Deves fazer com que a Itália e as províncias fiquem, de alguma maneira, livres de perturbações. E isto não é difícil de ser feito. 5. De fato, são sempre os mesmos que causam desgraças ao abandonar suas casas e ocupar outras ilicitamente. 6. Da mesma forma, deves fazer com que o serviço militar não seja injusto ou desigual, como tem sido até agora, quando alguns têm trinta anos de serviço prestado, enquanto outros sequer chegam a servir. 
O frumento, que foi dado outrora como um prêmio aos ignavos, convêm distribui-lo pelos municípios e colônias àqueles que retornarem a seus lares tendo cumprido o tempo de serviço militar”.

Na segunda epístola, por sua vez, César é aconselhado sobre o que deve fazer para evitar o conflito (5.1 - 12.4), i.e., aumentar o número de cidadãos romanos, promover a concórdia entre jovens e velhos, diminuir a ganância, corrigir a plebe e aumentar a autoridade do senado com a mudança do número de senadores e das regras de eleição. O conselho é expressamente dado nos passos seguintes:

Ep. ad Caes. II 5,8 Hos ego censeo permixtos cum ueteribus nouos in coloniis constituas: ita et res militaris opulentior erit et plebs bonis negotiis impedita malum publicum facere desinet.

Ep. ad Caes. II 5,8 “Eu creio que deves estabelecer os novos misturados aos mais velhos nas colônias; assim também a força militar será mais poderosa e a plebe, ocupada com assuntos virtuosos, deixará de promover o mal coletivo”.

Ep. ad Caes. II 7,2 Igitur, ubi eos in ciuitatem adduxeris, quoniam quidem reuocata plebes erit, in ea re maxume animum excerceto ut colantur boni mores, concordia inter ueteres et nouos coalescat. 3. Sed multo maxumum bonum patriae, ciuibus, tibi, liberis, postremo humanae genti pepereris, si studium pecuniae aut sustuleris, aut, quoad res feret, minueris: aliter neque priuata res, neque publica, neque domi, neque militiae, regi potest.

Ep. ad Caes. II 7,2 “Assim, quando os trouxeres à cidade, e assim ter verdadeiramente renovado a plebe, empenha maximamente o ânimo na tarefa de aumentar a concórdia entre 
os mais velhos e os novos, a fim de se cultivarem os bons costumes. 3. Mas terás alcançado um bem muito maior à pátria, aos cidadãos, a ti e aos filhos, enfim à humanidade inteira, se eliminares a ganância de dinheiro ou, até onde puderes, diminuí-la. Não há outra maneira de poder governar os assuntos íntimos ou a república, nem na paz ou na guerra”

Ep. ad Caes. II 7,10 Ergo in primis auctoritatem pecuniae demito: neque de capite, neque de honore ex copiis quisquam magis, aut minus iudicauerit; sicut neque praetor, neque consul, ex opulentia, uerum ex dignitate creetur. 11. Sed de magistratu facile populi iudicium fit. Iudices a paucis probari, regnum est; ex pecunia legi, inhonestum. Quare omnes primae classis iudicare placet, sed numero plures, quam iudicant.

Ep. ad Caes. II 7,10 "Portanto, a primeira coisa a fazer é acabares com o poder do dinheiro. Que nenhum indivíduo seja julgado maior ou menor na dignidade ou na honra por suas posses, nem se crie um pretor ou cônsul com base na opulência, e sim na dignidade. 11. Mas em relação à magistratura, o povo facilmente emite um juízo. É uma tirania os juízes serem nomeados por poucos, e desonesto serem escolhidos por sua riqueza. Por isso é conveniente que todos os da primeira classe julguem, mas em número maior do que os que julgam”.

Ep. ad Caes. II 11,5 Igitur duabus rebus confirmari posse senatum puto: si numero auctus per tabellam sententiam feret. Tabella obtentui erit, quo magis animo libero facere audeat: in multitudine, et praesidii plus, et usus amplior est.

Ep. ad Caes. II 11,5 "Portanto, julgo que o senado pode se fortalecer em dois pontos: se tiver aumentado o número de senadores e promover o voto secreto. Esse voto servirá de meio para que eles se exponham com o ânimo mais livre; o número maior no total traz tanto mais segurança quanto mais utilidade”. 
Na primeira epístola, César é aconselhado a abrandar o poder com benignidade e clemência, porque isso fará seu poder duradouro (Ep. ad Caes. I 3,2; 6,4); na afirmação da paz, César deve evitar os perigos de um conflito civil - a fim de que Roma não caia no poder de estrangeiros (Ep. ad Caes. I 5,2) - por meio da contenção das despesas dos cidadãos e da recusa ao poder do dinheiro e dos prazeres (Ep. ad Caes. I 7,1; 7,4; 8,1).

Na segunda epístola, por sua vez, César é aconselhado a promover a concórdia entre jovens e velhos, porque nisso a nobreza e os plebeus não verão sua liberdade afetada (Ep. ad Caes. II 5,16) e os bons costumes serão cultivados (Ep. ad Caes. II 7,1); diminuir a ganância, porque disso depende a grandeza do império romano (Ep. ad Caes. II 7,5); eliminar o poder do dinheiro, porque disso deriva a virtude e a dignidade dos cidadãos (Ep. ad Caes. II 8,1-5); corrigir a plebe e aumentar a autoridade do senado com a ampliação do número de senadores e com a mudança das regras de eleição, porque assim a república terá maior vigor, e a nobreza, menos poder (Ep. ad Caes. II 9,2).

Como é possível perceber, nas duas Ep. ad Caes. César desempenha ao mesmo tempo uma função moderadora e moralizadora, na medida em que suas ações incidem, através de uma mudança de hábitos, sobre a plebe e sobre os magistrados com vistas a manter a ordem pública. Ao desempenhar essas funções, César está sendo representado como o político “condutor de homens” tal como esse é definido por Platão (Pol. 258E apud Wolff, 1999, p.46; Leis 757d-758a), a saber: simultaneamente, um rei, um senhor de escravos e um chefe de família. Nesse sentido, entende-se por político apenas aquele que possui uma “ciência régia”, já que sua competência restringe-se a comandar homens. Portanto, para ser político basta saber o que é preciso fazer em relação aos demais cidadãos.

Cícero resume essa ciência atribuindo ao princeps a virtude da prudentia ciuilis (De rep. I 13, 36-37; X Phil. 6), i.e., o conhecimento de todos os princípios da vida pública. Com isso, o princeps está habilitado a prever e/ou controlar qualquer movimento que se incline à desestabilização da república. Não por acaso, o princeps deve por isso ser reconhecido como 
optimus ciues.

Procedendo dessa forma, Cícero recupera a definição aristotélica de cidadão (politikós) como sendo aquele que participa nas questões relativas à cidade (Ar. Pol. 1275a 22), sobretudo no âmbito deliberativo e judiciário (Ar. Pol. 1275b 18-19), e cujas virtudes dependem da função que esse cidadão exerce. Sendo assim, ao se associarem uns com os outros, os cidadãos organizam-se numa estrutura de repartição de poderes estabelecidos hierarquicamente (Ar. Pol. 1275b 18-20). Disso deriva a definição de cidade (pólis) - que é uma comunidade na qual existem relações de poder - e a de constituição (politeia), determinada por essas relações (Ar. Pol. 1278b 9-11; 1278b 30 - 1279a 8).

Aristóteles é o primeiro a considerar o interesse visado pelo poder quando define a politeia. Heródoto (Hist. III 80-82), por exemplo, tinha em conta apenas o número de governantes e Platão (Rep. VIII 544a; Pol. 291d), a constituição ideal. Dessa maneira, e tendo em vista sempre o fim último da cidade, i.e., uma associação que visa ao bem comum, Aristóteles divide as constituições em dois grupos segundo a legitimidade. Há, pois, formas retas ou regimes políticos, entendidos como aqueles que buscam vantagens comuns, e formas viciosas ou regimes despóticos, entendidos como aqueles que buscam vantagens para os governantes (Pol. 1279A 17-20). Os regimes políticos são assim chamados porque são justos, enquanto os regimes despóticos constituem uma perversão deles (cf. Wolff, 1999, pp.105-118).

Ao descrever a república romana como uma constituição mista, tanto Políbio quanto Cícero retomam o que Platão e Aristóteles disseram sobre a constituição ideal e sobre a perversão dos regimes políticos. O esquema de Políbio, entretanto, tem sido apontado pela historiografia contemporânea (q.v. Mouritsen, 2007, pp. 5-7; Hölkeskamp, 2010, p. 25) como essencialmente formalista e muito mais direcionado para as estruturas institucionais, do que para as flexibilidades da vida pública (o cursus honorum, por ex.); já Cícero, que reporta no De re publica parte do que Políbio afirmara sobre a constituição das repúblicas no Livro VI de sua História (De rep. II. 14), 
reduz as deduções do historiador a um modelo de constituição ainda mais conservador:

De rep. I 26, 41 '<quae>dam quasi semina, neque reliquarum uirtutum nec ipsius rei publicae reperiatur ulla institutio. hi coetus igitur hac de qua causa instituti, sedem primum certo loco domiciliorum causa constituerunt; quam cum locis manuque saepsissent, eius modi coniunctionem tectorum oppidum vel urbem appellauerunt, delubris distinctam spatiisque communibus. omnis ergo populus, qui est talis coetus multitudinis qualem exposui, omnis ciuitas, quae est constitutio populi, omnis res publica, quae ut dixi populi res est, consilio quodam regenda est, ut diuturna sit. id autem consilium primum semper ad eam causam referendum est quae causa genuit ciuitatem. 42. deinde aut uni tribuendum est, aut delectis quibusdam, aut suscipiendum est multitudini atque omnibus. quare cum penes unum est omnium summa rerum, regem illum unum uocamus, et regnum eius rei publicae statum. cum autem est penes delectos, tum illa ciuitas optimatium arbitrio regi dicitur. illa autem est ciuitas popularis (sic enim appellant), in qua in populo sunt omnia. atque horum trium generum quoduis, si teneat illud uinculum quod primum homines inter se rei publicae societate deuinxit, non perfectum illud quidem neque mea sententia optimum, sed tolerabile tamen, et aliud alio possit esse praestantius. nam uel rex aequus ac sapiens uel delecti ac principes ciues, uel ipse populus, quamquam id est minime probandum, tamen nullis interiectis iniquitatibus aut cupiditatibus posse uidetur aliquo esse non incerto statu.

De rep. I 26, 41 “[...] como simples sementes, não é possível encontrar organização alguma das demais virtudes nem da própria república. Assim, aquele ajuntamento constituiu, pelas razões que inicialmente apontei, uma sede em local determinado para estabelecer seus domicílios, defendida pela natureza e pela força humana, e a essa aglomeração de casas nomeou fortaleza ou cidade, dividida por templos e espaços públicos. Dessa forma, todo povo, que é a reunião de uma multidão conforme expus, toda cidade, que é a organização do povo, toda república que, como eu disse, é um bem do povo, devem ser geridos por algum 
tipo de autoridade para serem perenes. Além disso, essa autoridade deve ter sempre em vista a causa que originou a cidade. 42. Portanto o poder deve ser atribuído a um só, ou à seleção de alguns, ou ser assumido pela multidão e por todos. Por esse motivo, quando a um só se atribui o total das coisas, chamamo-lo rei, e reino o tipo de república. Quando, porém, é atribuído o poder aos escolhidos, então a república é caracterizada pela decisão soberana dos melhores. De outro lado, existe aquela república popular - pois é assim que a chamam - na qual tudo existe em função do povo. E qualquer um dentre estes três gêneros, mesmo se mantendo aquele vínculo que primeiramente uniu os homens entre si na comunhão da república, não é de fato perfeito nem, a meu ver, o melhor, porém tolerável, e um pode ser superior a outro. Pois tendo o poder um rei justo e sábio, ou os escolhidos e primeiros cidadãos, ou mesmo o povo, embora isso seja o menos provável, sem a intervenção de iniquidades e cobiças parece possível manter-se uma situação não instável”.

Cícero relaciona a origem da ciuitas à forma de governo, de maneira a ser duradoura ${ }^{56}$. Como as razões da origem da ciuitas foram descritas em um trecho da obra perdido, resta a sua conclusão quanto a classificar em três grupos essas constituições. Há, portanto, o governo atribuído a um só - o rei - numa constituição denominada monarquia ${ }^{57}$; há, também o governo daqueles que são escolhidos por sua autoridade ${ }^{58}$ e, por fim, a constituição democrática, na qual o poder é exercido pelo povo ${ }^{59}$. Estes três grupos não são perfeitos nem os melhores, podendo-se suceder um ao outro segundo sua eficácia ${ }^{60}$.

Reconhecendo que da monarquia (regnum) o povo está excluído ${ }^{61}$, que o poder da aristocracia (optimatium dominatio) impede a participação efetiva do povo no poder e nas

56 omnis res publica [...] consilio quodam regenda est, ut diuturna sit. id autem consilium primum semper ad eam causam referendum est quae causa genuit ciuitatem.

57 grifo meu, quare cum penes unum est omnium summa rerum, regem illum unum uocamus, et regnum eius rei publicae statum.

58 grifo meu, cum autem est penes delectos, tum illa civitas optimatium arbitrio regi dicitur.

59 grifo meu, illa autem est ciuitas popularis - sic enim appellant - in qua populo sunt omnia.

60 non perfectum illud quidem neque mea sententia optimum, sed tolerabile tamen, et aliud alio possit esse praestantius.

61 De rep. I 27, 43 sed et in regnis nimis expertes sunt ceteri communis iuris et consilii. 
deliberações públicas ${ }^{62}$ e que a democracia (omnia per populum geruntur) não reconhece méritos individuais, tornando injusta em si mesma a igualdade de direitos ${ }^{63}$, Cícero opõe pares de constituições que levam à transformação (commutatio) das repúblicas:

De rep. I 28, 44 Atque hoc loquor de tribus his generis rerum publicarum non turbatis atque permixtis, sed suum statum tenentibus. quae genera primum sunt in iis singula uitiis, quae ante dixi, deinde habent perniciosa alia uitia; nullum est enim genus illarum rerum publicarum, quod non habeat iter ad finitimum quodam malum praeceps ac lubricum.

De rep. I 28, 44 "Isto também digo acerca destes três gêneros de repúblicas, não desordenados e confundidos, mas mantendo seu próprio estado. Cada gênero de que primeiro falei traz vícios dentro de si, adquirindo depois outros vícios perniciosos; não há nenhum gênero de república que em seu limite não possua algum mal perigoso e incerto”.

Dessa maneira, quando o rei começa a ser injusto a monarquia degenera em tirania ${ }^{64}$; quando a tirania é previsivelmente derrubada pelos optimates, surge o governo aristocrático ${ }^{65}$, constituição excedida em excelência apenas pela monarquia, pois, tal como um rei, os optimates devem se empenhar como pais no bem-estar de todo o povo, desde que estabeleça com ele uma relação de respeito à liberdade (libertas).

Quando moderada ou comedida, a libertas constitui, ao lado da auctoritas senatorial $^{66}$, um elemento imprescindível para o gênero perfeito de república que Cícero deseja progressivamente

62 ibid., in optimatium dominatu uix particeps libertatis potest esse multitudo cum omni consilio communi ac potestate careat.

63 ibid., cum omnia per populum geruntur quamuis iustum atque moderatum, tamen ipsa aequabilitas est iniqua, cum habet nullos gradus dignitatis.

64 id., I 42, 65, cum rex iniustus esse coepit, perit illud illico genus, et est idem ille tyrannus, deterrimum genus et finitimum optimo.

65 ibid., quem si optimates opresserunt, quod ferme euenit, habet statum res publica de tribus secundarium; est enim quasi regium, id est patrium consilium populo bene consulentium principum.

66 De rep. II 33, 57, id tenetote quod initio dixi, nisi aequabilis haec in civitate conpensatio sit et iuris et officii et muneris, ut et potestatis satis in magistratibus et auctoritatis in principum consilio et libertatis in populo sit, non posse hunc incommutabilem rei publicae conservari statum. 
demonstrar ${ }^{67}$ :

De rep. I 44, 68 sic omnia nimia, cum uel in tempestate uel in agris uel in corporibus laetiora fuerunt, in contraria fere conuertuntur, maximeque <id $>$ in rebus publicis euenit, nimiaque illa libertas et populis et priuatis in nimiam seruitutem cadit. [...] sic tanquam pilam rapiunt inter se rei publicae statum tyranni ab regibus, ab iis autem principes aut populi, a quibus aut factiones aut tyranni, nec diutius unquam tenetur idem rei publicae modus.

De rep. I 44, 68 “Tal como todas as coisas excessivas que, fertilizadas quer pela chuva, quer pela agricultura, quer pelos dotes físicos, não cabem em si e convertem-se inteiramente no seu oposto, assim ocorre com as repúblicas - sobretudo com elas - e a excessiva independência tanto para o povo quanto para cada indivíduo se transforma em servidão excessiva [...]. Assim, como uma bola cuja posse disputam entre si, os tiranos tomam a constituição da república dos reis, e desses, por sua vez, os aristocratas ou o povo, e desses ainda ou as facções ou os tiranos, sem que por muito tempo se mantenha o mesmo tipo de república”.

A monarquia, que prosperara até Tarquínio, degenerou porque esse tomara o poder de seu antecessor (Sérvio Túlio) pelo assassinato, sujeitando-se por isto a ser temido pelos súditos ${ }^{68}$; tornou-se soberbo tanto por suas vitórias quanto por suas riquezas e sucumbiu às suas afecções e desejos $^{69}$, sendo deposto por Lúcio Bruto após o estupro de Lucrécia, crime cometido por seu próprio filho. É por causa de Tarquínio, alcunhado o Soberbo, que se dá em Roma o nome de tirano àquele que exerce um poder personalizado - diferindo do tirano grego que é, fundamentalmente,

67 De rep., II 1, 3, grifo meu, facilius autem quod est propositum consequar, si nostram rem publicam vobis et nascentem et crescentem et adultam et iam firmam atque robustam ostendero.

68 De rep. II 25, 45 nam ille rex de quo loquor, primum optimi regis caede maculatus integra mente non erat, et cum metueret ipse poenam ad sceleris sui summam, metui se uolebat.

69 ibid., deinde uictoriis diuiisque subnixus exultabat insolentia neque suos mores regere poterat neque suorum libidines. 
um rei injusto ${ }^{70}$ - e que aspira à monarquia, fazendo com que o populus sinta repúdio tanto pela figura do rei quanto pela figura do tirano:

De rep. II 30, 52 Iis enim regiis quadraginta annis et ducentis paulo cum interregnis fere amplius praeteritis, pulsoque Tarquinio, tantum odium populum Romanum regalis nominis tenuit, quantum tenuerat post obitum uel potius excessum Romuli desiderium. itaque ut tum carere rege, sic pulso Tarquinio nomen regis audire non poterat.

De rep. II 30, 52 "Passados então pouco mais de duzentos e quarenta anos de monarcas e entrerreis [interregnis], o povo romano passou a ter, após a expulsão de Tarquínio, tanto de ódio quanto tivera de desprezo pelo termo “real” na época da morte ou antes, do desaparecimento, de Rômulo. E assim, da mesma forma que prescindira de rei não suportava, após a expulsão de Tarquínio, sequer ouvir a palavra "rei”.

Não servem para Roma, portanto, nem a constituição democrática, menos ainda a anarquia; não lhe serve também a constituição monárquica, menos ainda a tirania. Também não lhe servirá nem a constituição aristocrática, nem a oligárquica. A criação dos decênviros, homens aos quais se reservava poder sumo e irrestrito e a quem Roma devia suas leis escritas ${ }^{71}$ serviu apenas para render aos cidadãos toda a sorte de arbitrariedades:

De rep. II 37, 62 in hoc statu rei publicae, quem dixi iam saepe non posse esse diuturnum, quod non esset in omnis ordines ciuitatis aequabilis, erat penes principes tota res publica, praepositis decemuiris nobilissimis, non oppositis tribunis plebis, nullis aliis adiunctis magistratibus, non prouocatione ad populum contra necem et uerbera relicta.

De rep. II 37, 62 “nesta situação da república, que eu já muitas vezes disse não poder ser

70 De rep. II 27, 49 Habetis igitur primum ortum tyranni; nam hoc nomen Graeci regibus iniustis esse uoluerunt; nostri quidem omnes reges uocitauerunt, qui soli in populos perpetuam potestatem haberent.

71 De rep. II 36, 61 cum summa esset auctoritas in senato populo patiente atque parente, initia ratio est, ut et consules et tribuni plebis magistratu se abdicarent, atque xuiri maxima potestate sine prouocatione crearentur, qui et summum imperium haberent el leges scriberent. 
duradoura pois não havia equidade em todas as partes da comunidade, toda ela obedecia somente aos governantes, aos dez homens escolhidos, sem que pudesse haver oposição dos tribunos da plebe, de outros magistrados a eles adjuntos, sem direito de apelação popular contra a pena de morte e contra os castigos corporais”.

cujo ponto máximo foram as medidas de proibição de casamentos entre patrícios e plebeus. A aristocracia tornara-se deste modo despótica, cruel e avara contra o povo ${ }^{72}$ ao investir de todo o poder os homens cuja soberba excedia à própria virtude.

O que Cícero pretende fazer ao apresentar essas deficiências das repúblicas é fundamentar um modelo de constituição que pudesse, de um lado, ser duradouro e empírico e, por outro, que fosse estável, porque apoiado não na unilateraliade de poder - nas outras constituições demasiado concentrado em um ou outro dos grupos segundo o momento e a índole dos governantes - e sim na colaboração dos homens como seres naturalmente dispostos à associação.

As condições para o surgimento dessa constituição são apresentadas por Cipião já em $D e$ rep. I, 25, 39: est igitur [...] res publica res populi - “é pois a república um bem do povo” - e, como tal, não admite que o poder esteja nas mãos de um só, de poucos ou de todos de qualquer maneira, porque associado sob as leis e sob interesses comuns (ibid., populus autem non omnis hominum coetus quoquo modo congregatus, sed coetus multitudinis iuris consensu et utilitatis communione sociatus; "o povo, por sua vez, não é toda união de homens reunida de maneira qualquer, mas a união de uma multidão associada de acordo com uma legislação e com interesses em comum”), atualizando no tempo e no espaço romano o politikós anér aristotélico. Tanto em Aristóteles (Pol. 1251a) quanto em Cícero ${ }^{73}$, o homem é um ser naturalmente gregário, politikós, e se associa tanto pela capacidade de comunicar-se um com outro quanto pela necessidade mútua de auxílio - o que torna os homens iguais entre si - com vistas à própria sobrevivência. Enquanto houver aqueles que

72 idem II 37, 63 libidinoseque omni imperio et acerbe et auare populo praefuerunt.

73 De rep. I 25, 39 eius autem prima causa coeundi est non tam inbecillitas quam naturalis quaedam hominum quasi congregatio. 
se impõem à maioria por possuir bens e riquezas ${ }^{74}$ a res publica não existirá, porque não haverá aequabilitas iuris entre os homens. Se não existe igualdade de direitos entre os homens, não há para o populus a independência na fala e nas ações, libertas $^{75}$; não havendo libertas, a república deixa de ser uma associação entre os homens de acordo com leis e interesses comuns.

Essa associação encontra ainda mais sentido quando toma o homem como politikós e quando promove a firmeza da república. Assim, a melhor constituição é também aquela em que a libertas pode ser exercida segundo a aequabilitas iuris, esta calcada na firmeza (firmitudo) da constituição, configurada como algo adequado à vontade da maioria (ibid. res seruatas iudicio uoluntatique multitudinis). Somente esta associação garante a independência, a justiça e o direito, necessariamente in omnis ordines ciuitatis ${ }^{76}$ quando estreitamente unidos:

De rep. I 45, 69 Haec constitutio primum habet aequabilitatem quandam [magnam], qua carere diutius uix possunt liberi, deinde firmitudinem, quod et illa prima facile in contraria uitia conuertuntur, ut exsistat ex rege dominus, ex optimatibus factio, ex populo turba et confusio, quodque ipsa genera generibus saepe conmutatur nouis, hoc in hac iuncta moderateque permixta constitutione rei publicae non ferme sine magnis principum uitiis euenit. Non est enim causa conuersionis, ubi in suo quisque esta gradu firmiter collocatus et non subest, quo praecipitet ac decidat.

De rep. I 45, 69 “Esta constituição possui primeiramente certa equidade, [grande], da qual a duras penas os homens livres podem abster-se por muito tempo, e em seguida firmeza, enquanto aqueles primeiros gêneros facilmente convertem-se em seus vícios contrários, de maneira que surja do rei um tirano, dos aristocratas uma facção, do povo a turba e a confusão. E ainda que os gêneros muitas vezes convertam-se em gêneros novos, este gênero - oriundo da junção equilibradamente misturada [de cada] constituição de

74 idem, I 32, 48, populo aliquis unus pluresue diuitiores opulentioresque existissent, tum ex eorum fastidio et superbia nata esse commemorant cedentibus ignauis et inbecillis et adrogantiae diuitum succumbentibus.

75 idem, I 31, 47, nulla alia in ciuitate, nisi in qua populi potestas summa est ullum domicilium libertas habet.

76 De rep. II 37, 62 in hoc statu rei publicae, quem dixi iam saepe non posse esse diuturnum, quod non esset in omnis ordines ciuitatis aequabilis 
república - não decai ordinariamente a não ser pelos terríveis vícios dos governantes. Não há, pois, motivo de transformação quando cada um está firmemente apoiado em seu lugar e não encontre modo de precipitar-se e cair”.

A aequabilitas iuris e a firmitudo rei publicae (Lepore, 1954, p.265), contrapostas a todas as deficiências das constituições das repúblicas, sustentam a república romana, genus mixtum que abriga em si o melhor das outras constituições ${ }^{77}$. Sendo o resultado da fusão das três espécies virtuosas de constituição ${ }^{78}$ e firmando-se na equidade e no apoio recíproco entre as partes, a república romana faz com que senado e povo desempenhem, cada qual, funções que lhes são próprias $^{79}$. Neste sentido, a república romana difere de todas as outras constituições por ser toda ela original $^{80}$, mista das três diversas formas de governo de maneira equilibrada (temperata), cujas leis não foram criadas por um só, mas por muitos legisladores e durante vários séculos ${ }^{81}$, na medida em que existe comunhão de interesses; essa ausente, há discórdia ${ }^{82}$. Caso o povo tome sozinho o poder, instala-se o caos; caso seja a aristocracia (optimates), deixa de haver o coetus multitudinis iuris consensu et utilitatis communione sociatus em favor do uso da violência e da força ${ }^{83}$; ademais, as leis e o direito perdem sua finalidade: serem comuns a todos ${ }^{84}$.

Especialmente na segunda Ep. ad Caes., César contempla o papel de moderador e moralizador dentro da comunidade pela contenção do poder dos mais nobres e pela devolução da libertas à plebe (Ep. ad Caes II 2,4), no que dista de Pompeu, que delegara aos mais nobres as

77 De rep. I 45, 68, quod cum ita sit, <ex> tribus primis generibus longe praestat mea sententia regium, regio autem ipsi praestabit id, quod erit aequatum et temperatum ex tribus optimis rerum publicarum modis.

78 De rep. I 29, 45 grifo meu, itaque quartum quoddam genus rei publicae maxime probandum esse sentio, quod est ex his quae prima dixi moderatum et permixtum tribus.

79 idem I 19, 31 senatum uero et populum ut unum habeamus, et fieri potest, et permolestum est nisi fit, et secus esse scimus et uidemus, si id effectum est, et melius nos esse uicturos et beatius [fala de Tuberão].

80 idem II 42, 23 quod erit eius modi, nihil ut tale ulla re publica reperiatur.

81 idem II 1, 1 nostra autem res publica non unius esse ingenio, sed multorum, nec una hominis uita, sed aliquot constituta saeculis et aetatibus. Nam neque ullum ingenium tantum existisse dicebat [Cipião] ut, quem res nulla fugeret quisquam aliquando fuisset, neque cuncta ingenia conlata in unum tantum posse uno tempore prouidere, ut omnia complecte rentur sine rerum usu ac uetustate.

82 idem I 32, 49 facillimam autem in ea re publica esse <posse> concordiam, in qua idem conducat omnibus; ex utilitatis uarietatibus, cum aliis aliud expediat, nasci discordias.

83 idem III 31, 43 ergo illam rem populi, id est rem publicam, quis diceret tum, cum crudelitate unius opressi essent uniuersi, neque esset unum uinculum iuris nec consensus ac societas coetus, quod est populus?

84 idem I 32, 49 quare cum lex sit ciuilis societatis uinculum, ius autem legis aequale, quo iure societas ciuium teneri potest, cum par non sit condicio ciuium? [...] Quid est enim ciuitas nisi iuris societas ciuium? 
decisões mais importantes (Ep. ad Caes II 3,2-4). Há, portanto, uma situação de conflito devido à má disposição do poder, excessivamente concentrado nas mãos de apenas um dos grupos da comunidade. Trata-se de um problema histórico, que o orador recupera na segunda epístola ao mencionar a antiga configuração da cidade:

Ep. ad Caes. II 5,1 In duas partes ego ciuitatem diuisam arbitror, sicut a maioribus accepi, in Patres et plebem. Antea in patribus summa auctoritas erat, uis multo maxuma in plebe. 2. Itaque saepius in ciuitate secessio fuit, semperque nobilitatis opes deminutae sunt et ius populi amplificatum. 3. Sed plebs eo libere agitabat, quia nullius potentia super leges erat; neque diuitiis, aut superbia, sed bona fama factisque fortibus nobilis ignobilem anteibat: humillumus quisque in aruis aut in militia nullius honestae rei egens satis sibi satisque patriae erat. 4. Sed ubi eos paulatim expulsos agris inertia atque inopia incertas domos habere subegit, coepere alienas opes petere, libertatem suam cum republica uenalem habere.

Ep. ad Caes. II 5,1 “Em duas partes eu julgo que a cidade está dividida - de acordo com o que tive conhecimento dos antigos: em patrícios e plebe. Antigamente, aos patrícios pertencia o sumo poder, e à plebe uma força muito maior. 2. Foi assim que muitas e muitas vezes houve conflito na cidade, e sempre a força da nobreza foi diminuída e o direito do povo, ampliado. 3. Mas a plebe até ali vivia livremente, porque o poder de ninguém estava acima das leis, nem o nobre se antepunha ao ignóbil pelas riquezas ou soberba, mas pela boa fama de suas ações: o homem mais humilde não era privado, nas lavouras ou na milícia, de nenhuma coisa honesta - era o bastante para si e para a pátria. 4. Mas quando a inércia e a pobreza paulatinamente obrigaram-nos, expulsos dos campos, a ter morada incerta, eles começaram a reivindicar outros haveres e a tratar sua liberdade, e com ela a república, como algo venal”. 
Ep. ad Caes. II 10,7 Itaque maiores nostri, quum bellis asperrumis premerentur, equis, uiris, pecunia amissa, nunquam defessi sunt armati de imperio certare. Non inopia aerarii, non uishostium, non aduorsa res, ingentem eorum animum subegit, quin, quae uirtute ceperant, simul cum anima retineret. 8. Atque ea magis fortibus consiliis, quam bonis proeliis, patrata sunt. Quippe apud illos una respublica erat, ei omnes consulebant; factio contra hostes parabatur; corpus atque ingenium, patriae, non suae quisque potentiae, exercitabat. 9. Ac hoc tempore contra, homines nobiles, quorum animos socordia atque ignauia inuasit, ignari laboris, hostium, militiae, domi factione instructi, per superbiam cunctis gentibus moderantur.

Ep. ad Caes. II 10,7 “Assim os nossos antepassados, ao se ferirem nas guerras mais cruéis, e terem perdidos os cavalos, os soldados e o dinheiro, jamais se privaram, armados, de lutar pelo poderio romano. Nem a falta de erário, nem a força dos inimigos, nem a adversidade sujeitou-lhes a enorme coragem, pois o que conquistaram com virtude, deram o mesmo valor que à vida. 8. E os ganhos foram obtidos mais pelos conselhos honestos do que pelas boas batalhas. Já que a república era, na concepção deles, unificada, todos ocupavamse dela, um só grupo armava-se contra os inimigos, cada um exercitava o corpo e a mente não para sua própria força, mas para a pátria. 9. Mas, ao contrário daquela época, atualmente os homens nobres, a cujas almas invadiram a preguiça e a ignomínia, alheios aos esforços de guerra dos inimigos e peritos em conspiração dentro de casa, governam todos os povos com a soberba”.

Na primeira epístola, em que o conselho se refere aos procedimentos após a guerra, César contempla o papel de moderador e moralizador a fim de evitar um novo conflito entre concidadãos, responsável pela dissolução da república pela natureza mesma de uma guerra civil (Ep. ad Caes. I 4, 2-4; 5, 1-2). Em ambas as epístolas, César é aconselhado a moralizar os mais jovens a fim de que 
aprendam com os mais velhos os códigos de conduta da vida civil (Ep. ad Caes. I 5,5; 6,1-4; II 7,2), uma vez que a concórdia entre os cidadãos depende também desses códigos. Por isso, são requeridas as virtudes da “ciência régia” platônica ou, ainda, a prudentia civilis de Cícero (cp. Ep. ad Caes. II 10,4-5). Nisso, porém, altera-se a própria configuração tradicional da república romana, uma vez que o papel moderador e moralizador de César sobrepõe-se ao poder deliberativo do senado, e mesmo ofusca a atuação da plebe (cp. Wirszubski, 2004, p. 111), reduzida à obediência a esse órgão consultivo e à submissão ao poder centralizador do imperator tal como é apresentado pelo orador (Ep. ad Caes. I 1,6; 1,8; 3,1; 3,3; 5,1; 5,4; 6, 4-5; 7, 1-4; 8,4; 8,6; II 4,4; 5,6-8; 6,1; 7,3; $7,10-11 ; 10,1 ; 10,6 ; 12,1-2)$.

Com efeito, a participação popular na república romana ainda hoje é fonte de caloroso debate entre os historiadores, dada a dificuldade de estabelecimento de um limite claro da atuação popular nos assuntos relacionados à política interna e externa e de seu papel nas eleições de magistrados. Fergus Millar, por exemplo, trata o populus romanus como um corpo soberano na república romana (Millar, 2002, p. 4-7; 18-19; 21-22; 139-143; 146-147; 2002 (b), p. 111; 114; 125) e qualifica como “ortodoxas” as análises que veem no senado romano o centro de uma constituição verdadeiramente oligárquica (ibid.). Com isso, sua análise abre um precedente inédito de definição da república romana como uma “democracia direta” - mais ou menos próxima da democracia ateniense - na qual o debate era o centro propulsor das ações dos magistrados dentro de um grupo social em que a palavra funcionava, ao mesmo tempo, como fonte e demonstração de poder.

Por outro lado, a corrente "revisionista”, da qual fazem parte os trabalhos de Hölkeskamp (2010) e de Mouritsen (2007), estranha o caráter sistemático da constituição romana dado por Millar (Hölkeskamp, 2010, p. 12). Ao contrário, a república romana aparenta ter sido constituída por uma complexa rede de responsabilidades, direitos e competências baseadas no mos maiorum, ou seja, em princípios e regras morais que envolviam conceitos-chave como auctoritas, dignitas, gratia e honos. Uma vez que esses conceitos fossem essencialmente conservadores, e por isso mesmo excludentes, o mos maiorum servia tanto para que a república se autorregulasse quanto para 
tornar o senado - o órgão que reunia os cidadãos reconhecidos publicamente por esses valores importante pela sua posição e pelo seu poder irrestrito. Todas as assembleias populares - os comitia centuriata, os comitia tributa e os concilia plebis - dividiam os cidadãos, distinguiam o poder de voto e a equidade entre eles, e assim reduziam o poder do populus romanus como um todo (Hölkeskamp, 2010, p. 13; 17-22; Hölkeskamp in Beck et alii [org.], 2011, p. 165). A importância crescente dessas assembleias, à medida que se registravam os conflitos entre os mais influentes (desde Mário e Sula até Marco Antônio e Otaviano), indicaria não a abertura para a “democracia direta”, mas uma redução significativa do poder do senado.

Conflitos entre membros desse órgão consultivo, generais e cavaleiros aparecem nas monografias de Salústio e em muitos discursos de Cícero. Envolvem, em geral, figuras ilustres que se colocavam ora em defesa da vontade popular (populares), ora como defensores de valores tradicionais da república romana (optimates) (q.v. Cíc. Ses. 31.67; 37.79; 44.95-46.90). Pensava-se outrora que essa era uma oposição “ideológica” entre dois grupos de aristocratas; entretanto, os estudos historiográficos mais recentes (cf. Morstein-Marx, 2004, pp. 204-240) desconstroem a oposição entre optimates e populares como ideologias distintas ou comportamento de grupos rivais. Há, na verdade, disputas entre indivíduos, que se valem de expedientes diferentes para manifestar um comportamento mais (ou menos) solícito em relação ao povo. Isso porque, a depreender do que Cícero escreve no De re publica (I 52. 5) e em Ses. 65.137, o povo jamais deve julgar que suas comodidades sejam negligenciadas pelos principes. Quer dizer, aceita-se a ideia de que o senado é provedor do povo romano, e de que ambos estão conscientes disso, na medida em que é a partir desse pacto que a república pode existir.

Por causa desse pacto (a concordia ordinum) não há um conflito institucional. O que há são indivíduos que buscam nas assembleias da plebe (contiones) ou nos comícios (comitia) o respaldo para aquilo que julgam melhor para a comunidade (ciuitas). Entram no jogo de interesses pessoais, de um lado, a construção, por parte de um optimate, da figura do popular “demagogo” e, do outro lado, a da figura do optimate levado pela ganância e incitação ao ódio (concitatio inuidiae). O 
ataque entre as partes é moral, quando não físico.

César é lembrado como um líder conciliador tanto por Salústio quanto por Cícero. No discurso que Salústio elabora, na Conjuração de Catilina (51.1-43), como fala de César, por exemplo, em mais de uma passagem ele demonstra essa qualidade - especialmente ao defender o mos maiorum citando os exemplos dos antepassados $(51.4$; 15; 32-34; 37) e ao lamentar a desgraça da república quando das ações de Catilina (51.9-12; 21-24; 40; 43). Nesse discurso, César é apresentado, sobretudo, como um defensor da república combalida, o que demonstra um compromisso institucional, mais que do que pessoal. Nesse sentido, o César da monografia de Salústio dista significativamente daquele elaborado nas Ep. ad Caes., pois nas duas epístolas o poder do imperator é essencialmente centralizado.

Por sua vez Cícero, na oração Pro Marcello, apresenta as virtudes do príncipe por meio do elogio de César (Pro Mar. I 1): mansidão (mansuetudo), clemência (clementia), moderação (modum) e sabedoria (sapientia). Todas essas virtudes coordenam-se após a vitória de César nas guerras civis, por onde Cícero encontra razões para o elogio das atitudes do general em relação à república (Pro Mar. I 2 rei publicae conservatam ac restitutam; “a república conservada e restituída”), aos vencidos e, em especial, ao próprio orador. A moderação é elogiada pela cautela na vitória (Pro Mar. III 8 Animum vincere, iracundiam cohibere, victoriam temperare [...] non ego eum cum summis viris comparo, sed simillimum deo iudico; "vencer o ânimo, coibir a fúria, temperar a vitória [...] não o comparo aos homens mais nobres, e sim mais semelhante a um deus”); a clemência, pela força do perdão depositada na vitória (Pro Mar. IV 12 clementiae tuae iudicio conservati sumus; “fomos salvos pelo bom senso da tua clemência”); a moderação, no freio à sede de vingança e no controle de si mesmo (Pro Mar. IV 12 Et ceteros quidem omnis victores bellorum civilium iam ante aequitate et misericordia viceras: hodierno vero die te ipsum vicisti; "com efeito, já havias vencido na equidade e na misericórdia todos os demais vencedores das guerras civis: no dia de hoje, porém, venceste a ti mesmo”) e a sabedoria, pela preservação da vida daqueles que lutaram pela paz e pela urgência da restituição da república à sua antiga configuração (Pro Mar. V 
15; IX 27). A tais virtudes soma-se ainda a justiça (Pro Mar. III 9 cum aliquid clementer, mansuete, iuste, moderate, sapienter factum; "tendo realizado algo com clemência, com mansidão, com justiça, com moderação e com sabedoria”) dada a quem lutou mais por ignorância, que por ambição (Pro Mar. V 13 iudicavit a plerisque ignoratione potius et falso atque inani metu quam cupiditate aut crudelitate bellum esse susceptum; “julgou, pela ignorância de muitos, mas muito mais por medo do que por ganância ou crueldade, ter declarado uma guerra”).

De um lado, essas virtudes elevam o valor da clemência que César demonstrou em relação aos vencidos na guerra civil; de outro lado, servem de base ao conselho que Cícero dá ao general vencedor. Nesse ponto, a oração de Cícero apresenta o mesmo conselho dado a César nas Ep. ad Caes., a saber: reprimir a ganância e a luxúria dos cidadãos romanos e oferecer o remédio necessário para a república recuperar-se:

Pro Mar. VIII 23 Omnia sunt excitanda tibi, C. Caesar, uni, quae iacere sentis, belli ipsius impetu, quod necesse fuit, perculsa atque prostrata: constituenda iudicia, revocanda fides, comprimendae libidines, propaganda suboles: omnia, quae dilapsa iam diffluxerunt, severis legibus vincienda sunt. 24. Non fuit recusandum in tanto civili bello, tanto animorum ardore et armorum, quin quassata res publica, quicumque belli eventus fuisset, multa perderet et ornamenta dignitatis et praesidia stabilitatis suae; multaque uterque dux faceret armatus, quae idem togatus fieri prohibuisset. Quae quidem tibi nunc omnia belli volnera sananda sunt, quibus praeter te nemo mederi potest.

Pro Mar. VIII 23 “Somente tu, C. César, podes recuperar, como é necessário, todas as coisas que vês caírem abatidas e prostradas pelo ímpeto mesmo da guerra: devem-se restabelecer os tribunais, restituir-se a lealdade, reprimirem-se os apetites, propagarem-se as famílias; tudo o que se dilatou deve ser prendido com leis severas. 24. Não se devia negar, em meio a tamanha guerra civil e a tanto ardor de ânimos e armas, que a república então combalida, 
qualquer que fosse o resultado da guerra, perdia muito dos ornamentos de sua dignidade e recursos de sua estabilidade: ambos os generais fizeram muitas coisas armados que, togados, não poderiam fazer. Por isso, tu deves sanar todas as feridas da guerra, porque nenhum outro além de ti poderá lhes dar remédio”.

Admitindo-se, entretanto, que Cícero concebe, no Pro Marcello, a clemência como o atributo de um líder que assume o papel de restaurador da república e, portanto, uma figura cuja liderança ainda assim justifica o poder como algo a ser compartilhado entre os mais sábios e virtuosos, sua concepção de princeps é distinta do que consta nas Ep. ad Caes., conquanto ambos os documentos apresentem muitos pontos em comum.

Os principais pontos em comum, e talvez os mais evidentes, são a falta de união entre os grupos na republica romana e a necessidade de uma figura - ninguém menos que César - que pudesse a contento proteger todos os ordines ciuitatis ${ }^{85}$, principalmente porque sua conduta não parecia apontar para a personalização do poder, mas para a restauração da paz e da reconciliação entre os cidadãos ${ }^{86}$, graças ao exercício de sua clemência ${ }^{87}$. Mas o mesmo exercício da clemência configura diferentes visões de exercício do poder.

O conceito de princeps ciceroniano não é constitucional (cp. Rosa [org.], 2010, p. 42-44), e sim um conceito ético e generalizante, plural, que designa, em seu limite, todo e qualquer cidadão que se empenha, nos atos e nas decisões, na defesa da constituição da republica, repudiando assim a concentração do poder em suas mãos em favor da concordia ordinum. Isso acontece porque a auctoritas principis será sempre uma autoridade pessoal, fundamentada na boa reputação (dignitas) e nos feitos (res gestae) daquele que a pleiteia. Ela é imprescindível para que o político, o princeps auctoritate, possa exercer o papel de rector et moderator rei publicae, ou seja, inspirar nas suas iniciativas e preeminência as decisões do senado, cujo papel na república é dirigir sob a forma do 
consilium: tomar decisões e deliberar, sem no entanto ter o poder de execução. Assim, a auctoritas, como poder de direção, mas não de execução é, sobretudo, um instrumento de ação política do senado, opondo-se ao imperium dos cônsules e fazendo do princeps um auctor publici consilii, tal como Cícero o configura no De oratore $^{88}$ : subordinando-se como indivíduo à república e assumindo não uma posição superior em relação aos outros cidadãos, mas detendo por direito a primazia de iniciativa dentro de um grupo.

Assim, na oração Pro Marcello, a clemência de César tem de atender, necessariamente, aos interesses da república, ou antes, confirmar, numa visão conservadora do poder, a liderança do senado e dos cônsules nos assuntos e nas resoluções de interesse público ${ }^{89}$, o que não ocorre nas Ep. ad Caes. Nelas, a clemência constitui um atributo que tanto confere ao príncipe uma autoridade monárquica quanto serve como medida para que o exercício do poder não leve o príncipe a transformar-se num tirano.

Quanto à inclinação de a clemência ser o atributo de um monarca, o trecho Ep. ad Caes. I 5.3-4 ${ }^{90}$, é bastante esclarecedor: nega a restauração da república e propõe uma reconfiguração da administração de modo que se concentrem nas mãos de um só decisões que versam, inclusive, sobre as despesas de cada família. Assim, o domínio sobre o qual se estende o poder de um só se amplia e justifica, à diferença de Cícero, que pregava, por meio da restauração do poder às instituições tradicionais republicanas, ser a maior vigilância sobre as atitudes dos cidadãos o meio mais eficaz de salvação da república. Abarcando as finanças públicas e privadas, aprumando as atividades dos magistrados e mesmo moralizando os mais jovens, o poder do príncipe chega a ser irrestrito.

Enquanto Cícero rejeita o poder autocrático, manifestado tanto pelo rei quanto pelo tirano, em favor de uma constituição mista (De rep. II 30, 52), Sêneca, no contexto do quinquenium Neronis, reconhece o poder do monarca e trata de justificar, no De clementia, a necessidade da

88 I 211 Sin autem quaereremus quis esset is, qui ad rem publicam moderandam usum et scientiam et studium suum contulisset, definirem hoc modo: qui quibus rebus utilitas rei publicae pareretur augereturque, teneret eisque uteretur, hunc rei publicae rectorem et consili publici auctorem esse habendum.

89 Pro Mar. IX, 27; III, 10; VII, 22-23.

90 firmanda igitur sunt < vel maxime> concordiae bona et discordiae mala expellenda. id ita eveniet, si sumptuum et rapinarum licentiam dempseris, non ad vetera instituta revocans, quae iam pridem corruptis moribus ludibrio sunt. 
moderação de atos do príncipe com vistas a evitar que ele se torne um tirano. Por isso, o conceito de clementia, para Sêneca, tem muito a ver com a noua ratio uincendi de César ${ }^{91}$, pois não apenas confere ao príncipe um poder absoluto e o modera, mas acaba sobretudo por justificar a própria existência do principado frente à immensam multitudinem discordem, seditiosam, impotentem, in perniciem alienam suamque pariter exsultaturam, si hoc iugum fregerit (De Clem. I, 1 “imensa multidão discorde, sediciosa, que há de se comprazer igualmente com a sua desgraça e com a dos demais caso afrouxe o jugo”). Assim é que a submissão ao príncipe, figura cujo poder só pode ser exercido por causa de sua sabedoria, evita os perigos da sublevação popular e estabelece valores que propiciam a coesão do império ${ }^{92}$, tornando imprescindível a centralização do poder, vinculada a uma série de valores justificativos do governo de um só. A sabedoria é uma delas; a outra é a clemência.

Com efeito, a clemência sempre foi um valor romano (Grimal, 1985, p. 255), mas, na perspectiva da filosofia estoica, justifica moralmente a imagem do monarca, e com essa acepção aparece nas Res gestae de Augusto (Res ges. I, 34 mihi senatum populumque Romanum dare uirtutis clementiaeque et iustitiae et pietatis caussa testatum est per eius clupei inscriptionem; "[o que] foi atestado pela inscrição desse escudo, que o senado e o povo romano me concederam por causa da minha virtude, da minha clemência, da minha justiça e da minha devoção”). Com isso, a clemência passa a integrar-se entre as virtudes cardinais (Grimal, 1985, pp. 254-257) que identificam o rei justo; a uirtus, que confere ao homem a capacidade de se desvencilhar dos acidentes causados por sua própria natureza; a pietas, que faz do príncipe, pater patriae, um protetor de seus súditos e a iustitia são os outros três. A clemência, que originalmente não fazia parte das categorias das virtudes estoicas (ibid. p. 255), passa a fazer parte do clupeus uirtutis que define o príncipe pelo fato de que ela acaba sendo, mais do que uma maneira de governar-se a si mesmo (cp. Cíc. Pro Mar. I, 1, in summa potestate rerum omnium modum; “a clemência é a moderação num poder absoluto”),

91 Braren, 1998, p. 18.

92 De Clem. I 4.1 Ille est enim vinculum, per quod res publica cohaeret, ille spiritus vitalis, quem haec tot milia trahunt nihil ipsa per se futura nisi onus et praeda, si mens illa imperii subtrahatur. 
a garantia de que o príncipe se aproxime da sabedoria e possa exercer o poder sem o risco de incorrer nos crimes que o caracterizariam como um tirano, tyrannus (Grimal, 1985, p. 256). Parte do princípio de que o poder tanto pode prejudicar quanto fazer o bem, e não está ligada apenas ao príncipe que o exerce, mas, sobretudo, aos homens sobre os quais o poder é exercido.

Nesse sentido, o lugar-comum da decadência dos costumes encontra uma recolocação entre os fundamentos da necessidade de um poder centralizador, já que determina uma hierarquia segundo a qual os piores homens devem se submeter aos melhores, porque moralmente superiores. Salústio, quando narra a conjuração de Catilina e atribui ao conspirador as características que justificam seus deméritos insinua que a decadência dos costumes contribui para a subversão dos cidadãos e exige um poder que impeça o caos provindo da dominação de um devasso. Possuir um caráter bom significa estar apto, não sem algum tipo de abdicação individual, aos negócios públicos; deixar-se levar pelos vícios, por sua vez, significa desestabilizar a república e por em risco a configuração de toda a organização da comunidade.

Enquanto a decadência dos costumes implica a necessidade de um poder centralizado, a clemência modera os atos do príncipe com vistas a tornar seu relacionamento com os cidadãos mais sensato e equilibrado, porque calcado na tolerância e na justiça. Essa impede a ostentação do poder pelo terror ${ }^{93}$, aquela abranda os subordinados, fazendo com que o soberano seja popular e permaneça por longo tempo no poder $^{94}$. Se, tal como Sêneca definira, o ser humano é mais suscetível a aceitar o que lhe convém obeceder que o que não lhe convém ${ }^{95}$, a clemência serve como uma espécie de atrativo para o príncipe modificar os maus costumes de seus subordinados ${ }^{96}$. Assim, o príncipe é tal como o médico que cura o paciente ${ }^{97}$.

93 Sên. De Clem. I I, 4 Severitatem abditam, at clementiam in procinctu habeo; sic me custodio, tamquam legibus, quas ex situ ac tenebris in lucem evocavi, rationem redditurus sim.

94 Omena, 2002, p. 95.

95 De Clem. I 24, 2 Natura contumax est humanus animus et in contrarium atque arduum nitens sequiturque facilius quam ducitur.

96 Ep. ad Caes. I 6.5 ea uera clementia erit: consuluisse ne immerito ciues patria expellerentur, retinuisse ab stultitia et falsis uoluptatibus, pacem concordiamque stabiliuisse, non si flagitiis opsecutus, delicta perpessus praesens gaudium quom mox futuro malo concesseris.

97 De Clem. I 2.1 Sed primum omnium, sicut medicinae apud aegros usus, etiam apud sanos honor est, ita clementiam, quamvis poena digni invocent, etiam innocentes colunt. 
Assim é que a submissão ao príncipe, figura cujo poder só pode ser exercido por causa de sua sabedoria, evita os perigos da sublevação popular e estabelece valores que propiciam a coesão do império ${ }^{98}$, tornando imprescindível a centralização do poder, vinculada a uma série de valores justificativos do governo de um só. A sabedoria é uma delas; a outra é a clemência.

Como instrumento de ação política, a clemência é conveniente ${ }^{99}$, necessária ${ }^{100}$ e honrosa ${ }^{101}$ para o príncipe, e se relaciona com outras três virtudes: a temperantia, a lenitas ${ }^{102}$ e a moderatio $^{103}$ (Braren in Sêneca/Salústio, p. 18). Não se opõe à severidade, uma vez que esta é uma virtude do governante no exercício da justiça ${ }^{104}$; no entanto, também não é compaixão, pois esta desvia a atenção que deve ser dada ao crime para o criminoso ${ }^{105}$, nem crueldade ${ }^{106}$. Trata-se por excelência da virtude de um príncipe porque torna seu poder estável ${ }^{107}$ e estabelece os bons costumes dos cidadãos, constituindo-se uma virtude disciplinadora ${ }^{108}$, sendo pois definida como temperantia animi in potestate ulciscendi vel lenitas superioris adversus inferiorem in constituendis poenis (De Clem. I 3,1 “Moderação do ânimo no poder de matar ou a leniência de um superior em relação a um inferior no estabelecimento de penalidades”).

O argumento que Sêneca utiliza tanto para justificar o governo monárquico como necessário frente à decadência dos costumes quanto para garantir solidamente o poder do príncipe como um ornamento que o dignifica é o de que a clemência opõe rei e tirano. Se, tal como Cícero, Sêneca

98 De Clem. I 4.1 Ille est enim vinculum, per quod res publica cohaeret, ille spiritus vitalis, quem haec tot milia trahunt nihil ipsa per se futura nisi onus et praeda, si mens illa imperii subtrahatur.

99 De Clem. I 16.1 O dignum, quem in consilium patres advocarent! O dignum, quem coheredem innocentibus liberis scriberent! Haec clementia principem decet.

100idem I 5.1 tu animus rei publicae tuae es, illa corpus tuum, vides, ut puto, quam necessaria sit clementia.

101idem I 9.4 Clementia ergo non tantum honestiores sed tutiores praestat ornamentumque imperiorum est simul et certissima salus.

102De Clem. II 1 Ut De clementia scriberem, Nero Caesar, una me vox tua maxime compulit, quam ego non sine admiratione et, cum diceretur, audisse memini et deinde aliis narrasse, vocem generosam, magni animi, magnae lenitatis, quae non composita nec alienis auribus data.

103idem I 3.2 Illa finitio contradictiones inveniet, quamvis maxime ad verum accedat, si dixerimus clementiam esse moderationem aliquid ex merita ac debita poena remittentem.

104De Clem. II 4.1 Huic contrariam imperiti putant severitatem; sed nulla virtus virtuti contraria est.

105De Clem. II 4.4 Ad rem pertinet quaerere hoc loco, quid sit misericordia; plerique enim ut virtutem eam laudant et bonum hominem vocant misericordem.

106De Clem. II 4.1 Quid ergo opponitur clementiae? Crudelitas, quae nihil aliud est quam atrocitas animi in exigendis poenis.

107De Clem. I 3.2 Nullam ex omnibus virtutibus homini magis convenire, cum sit nulla humanior, constet necesse est non solum inter nos, qui hominem sociale animal communi bono genitum videri volumus.

108De Clem. I 22.2 Constituit bonos mores civitati princeps et vitia eluit. 
identifica no latim os termos tyrannus e rex como sinônimos imperfeitos, pois ambos designam a forma de governo autocrática ${ }^{109}$, por outro lado limita a identificação entre rei e tirano pela conduta de um e de outro dizendo que, ao contrário do tirano, o rei é justo (De Ben. II 20,2 cum optimus ciuitatis status sub rege iusto sit; “uma vez que a melhor constituição da república reside num rei justo”). Estreitam-se aqui os laços entre a clemência e a justiça: essa deve levar em consideração os méritos ou deméritos de determinada pessoa ou situação em que o poder autorize - ou deva - punir. Assim, quando Sêneca pergunta Quid ergo? Non reges quoque occidere solent? (De Clem. I 12.1 "E quê? Os reis também não costumam matar?”), a resposta, Sed quotiens id fieri publica utilitas persuadet; tyrannis saevitia cordi est. Tyrannus autem a rege factis distat, non nomine (ibid. "Mas isso ocorre somente quando o persuade a utilidade pública; a crueldade está no coração dos tiranos. O tirano, contudo, dista do rei em feitos, não no nome”) leva em consideração que a clemência é a moderação justa numa situação em que o poder de um superior poderia levá-lo à crueldade (saeuitia $^{110}$. A crueldade é o oposto de clemência e define o tirano em oposição ao rex iustus: quod tyranni in uoluptatem saeuiunt, reges non nisi ex causa ac necessitate (De Clem. I 11,4 "Pois os tiranos fazem o mal por prazer, os reis senão por motivo e necessidade”). Por isso, Sêneca define o rei justo como:

De Clem. I 13,4 cui curae sunt universa, qui alia magis, alia minus tuetur, nullam non rei publicae partem tamquam sui nutrit, inclinatus ad mitiora, etiam, si ex usu est animadvertere, ostendens, quam invitus aspero remedio manus admoveat, in cuius animo nihil hostile, nihil efferum est, qui potentiam suam placide ac salutariter exercet adprobare

109De Clem. I 11.4 grifo meu, Quid enim est, cur reges consenuerint liberisque ac nepotibus tradiderint regna, tyrannorum exsecrabilis ac brevis potestas sit? Quid interest inter tyrannum ac regem (species enim ipsa fortunae ac licentia par est).

110De Clem. I 12,3 interim, hoc quod dicebam, clementia efficit, ut magnum inter regem tyrannumque discrimen sit, uterque licet non minus armis valletur; sed alter arma habet, quibus in munimentum pacis utitur, alter, ut magno timore magna odia compescat, nec illas ipsas manus, quibus se commisit, securus adspicit. 4. Contrariis in contraria agitur; nam cum invisus sit, quia timetur, timeri vult, quia invisus est, et illo exsecrabili versu, qui multos praecipites dedit, utitur: "Oderint, dum metuant", ignarus, quanta rabies oriatur, ubi supra modum odia creverunt. Temperatus enim timor cohibet animos, adsiduus vero et acer et extrema admovens in audaciam iacentes excitat et omnia experiri suadet. 
imperia sua civibus cupiens, felix abunde sibi visus, si fortunam suam publicarit, sermone adfabilis, aditu accessuque facilis, voltu, qui maxime populos demeretur, amabilis, aequis desideriis propensus, etiam inquis non acerbus, a tota civitate amatur, defenditur, colitur.

De Clem. I 13,4 "a quem tudo deve ser objeto de atenção; que atende mais certas coisas, menos outras e não alimenta nenhuma parte da república como se não fôra sua; inclinado à suavidade, mostrando, se é útil a censura, como, constrangido, move a mão, numa solução grosseira; cujo ânimo nada é hostil, nada é selvagem; que exerce seu poder plácida e saudavelmente, desejando que os cidadãos aprovem seu governo, considerando-se muito feliz se a sua boa sorte for também a pública. Afável nas palavras, fácil à aproximação e ao acesso, com uma face que cativa, sobretudo, o povo; amável, propenso às legítimas petições e nem um pouco ríspido também em relação às iníquas, por toda a comunidade é amado, defendido, respeitado”.

Levando-se em consideração essas características do rei justo, justifica-se assim o porquê de as referências ao príncipe ${ }^{111}$ e ao rei ${ }^{112}$ colocarem as duas expressões como sinônimas frente ao termo tirano, tyrannus, indicando rex e princeps a forma virtuosa de constituição autocrática; mais precisamente, isto ocorre nos passos De Clem. I 21,1 Principis maior est fortuna, quam ut solacio egeat, manifestiorque vis, quam ut alieno malo opinionem sibi virium quaerat. Hoc dico, cum ab inferioribus petitus violatusque est [...]. Regem et servus occidit et serpens et sagitta ("A felicidade do príncipe é maior do que a sua necessidade de amparo, e mais evidente a sua força do que o desejo de uma reputação assentada no mal alheio. Digo isso sendo o príncipe atacado e violado por inferiores [...]. Tanto um servo quanto uma serpente ou uma flecha matam um rei”) e, sobretudo, De Clem. I 4,3 Ideo principes regesque et quocumque alio nomine sunt tutores status publici non est mirum amari ultra privatas etiam necessitudines ("Portanto não é de se admirar que príncipes e reis

111De Clem. I 1, 5; I 1, 6; I 5, 1; I 5, 2; I 7, 1; I 9, 1; I 9, 10; I 10, 1; I 10, 2; I 10, 3; I 13, 5; I 15, 3; I 20, 1; I 21, 1; I 22, 3; I 24, 1; II 1, 2; II 1, 3.

112De Clem. I 3, 4; I 8, 1; I 13, 1; I 16, 1; I 19, 3; I 21, 1; II 1, 3. 
ou qualquer outro nome que se dê aos tutores da república dêem preferência a necessidades muito mais importantes que as individuais”).

O De clementia opõe-se, portanto, ao De re publica, pois estabelece princípios justificadores do poder do príncipe. Embora Sêneca reconheça o limite do poder quando do exercício da clemência $^{113}$, define o princeps como um cosmocrata, eleito não por acaso pelos deuses para exercer seu poder sobre o mundo.

Virtudes como a clementia e a moderatio, bem como a promoção do consensus e da concordia emergem, portanto, como valores de uma constituição autocrática que preserva muito da antiga república romana (Lobur, 2008, p. 7-8; 31). Em relação a essa, o principado difere no fato de que é resultado da mudança da distribuição de poder, devotado a apenas um membro do grupo, e que o consensus - a continuação da concordia ordinum ciceroniana - é promovido por esse membro ilustre, não pelo senado (Wiederman in Rowe and Schofield [org.], 2005, p. 521). Esse indivíduo, ao promover o consenso, previne a competição entre os nobres e unifica um grupo social essencialmente dividido pelas disputas pelo poder (Lobur, 2008, p. 39). Por isso, em termos de legitimação do poder do imperador, o principado é marcado pela encenação repetida desse consenso entre os cidadãos. Ao mesmo tempo, ela exige uma capacidade do detentor do poder de sobressairse aos demais em auctoritas e moderatio diante do poder absoluto. Dessa resulta o consensus; daquela, a potestas (q.v. Lobur, 2008, p. 13; 19-20; Veleio Pat. Hist. Rom. II 91,1).

Nas Ep. ad Caes. o conselho é dado em situação de desequilíbrio ora entre senado e plebe, ora entre indivíduos (César e Pompeu). Dessa maneira, promover a paz significa restabelecer a concórdia e promover o consenso - negando, nesse processo, a antiga constituição. Quer dizer, ao governar, César está autorizado a agir sozinho tanto pela degeneração dos membros mais ilustres do grupo social, quanto pela posição de liderança absoluta que conseguiu como imperator. Isso fica evidente nas seguintes passagens:

113De Clem. I 1,3 In hac tanta facultate rerum non ira me ad iniqua supplicia compulit, non iuvenilis impetus, non temeritas hominum et contumacia, quae saepe tranquillissimis quoque pectoribus patientiam extorsit, non ipsa ostentandae per terrores potentiae dira, sed frequens magnis imperiis gloria. Conditum, immo constrictum apud me ferrum est, summa parsimonia etiam vilissimi sanguinis; nemo non, cui alia desunt, hominis nomine apud me gratiosus est. 
Ep. ad Caes. I, 1.6 at contra id eniti decet, cum ipse bonus atque strenuus sis, uti quam optimis imperites, nam pessumus quisque asperrume rectorem patitur. 7. sed tibi hoc grauius est quam ante te omnibus, armis parta componere, quod bellum aliorum pace mollius gessisti. 8. ad hoc uictores praedam petunt, uicti ciues sunt. inter has difficultates euadendum est tibi atque in posterum firmanda res publica non armis modo neque aduorsum hostis, sed, quod multo multoque asperius est, pacis bonis artibus.

Ep. ad Caes. I, 1.6 "Convém te esforçares no sentido oposto, sendo, tu mesmo, bom e diligente, para que governes os melhores, 6. pois os piores homens suportam penosamente um chefe. 7. Mas para ti isto é mais difícil do que para todos aqueles que, antes de ti, conquistaram bens por meio das armas, pois foste mais direito na guerra do que outros, na paz. 8. Para isso os vencedores buscam a presa; os vencidos são cidadãos. Em meio a tais dificuldades deves também salvar e preparar a república para o futuro, não só com o apoio das armas ou com assaltos aos inimigos e sim - o que é muito e muito mais difícil - com as vantagens da paz”.

Ep. ad Caes. I, 2.1. Sed iam, quo melius faciliusque constituas, paucis quae me animus monet accipe.

Ep. ad Caes. I, II.1 "Mas agora, para que melhor e mais facilmente decidas que caminho seguir, aceita em poucas palavras o que o ânimo me adverte”.

Ep. ad Caes. I, 3.2 equidem ego cuncta imperia crudelia magis acerba quam diuturna arbitror, neque quemquam multis metuendum esse quin ad eum ex multis formido reccidat: eam uitam bellum aeternum et anceps gerere, quoniam neque aduersarius neque ab tergo aut lateribus tutus sis, semper in periculo aut metu agites. 3. contra qui benignitate et clementia imperium temperauere, iis laeta et candida omnia uisa, etiam hostes aequiores quam aliis ciues. 
Ep. ad Caes. I, 3.2 “Quanto a mim, julgo que todo império é mais cruel do que duradouro, e imagino que não haja alguém que a muitos assuste sem que de muitos tenha medo: viver desta maneira é duvidoso, é viver numa guerra eterna, porque jamais se está a salvo nempela frente, nem pelas costas, nem pelos lados, estando sempre em perigo ou assustado. 3. Quem, ao contrário, abrandou o poder com benignidade e clemência, a estes tudo parece feliz e calmo, e mesmo os inimigos dão-lhe um tratamento mais justo do que os cidadãos a estrangeiros”.

Ep. ad Caes. I 5.2 ego sic existimo: quoniam orta omnia intereunt, qua tempestate urbi Romanae fatum excidii aduentarit, ciues cum ciuibus manus conserturos, ita defessos et exsangues regi aut nationi praedae futuros. aliter non orbis terrarum neque cunctae gentes conglobatae mouere aut contundere queunt hoc imperium. 3. firmanda igitur sunt <uel maxime> concordiae bona et discordiae mala expellenda. 4. id ita eueniet, si sumptuum et rapinarum licentiam dempseris, non ad uetera instituta reuocans, quae iam pridem corruptis moribus ludibrio sunt; sed si suam quoique rem familiarem finem sumptuum statueris.

Ep. ad Caes. I 5.2 "Eu particularmente acredito que tudo o que nasce, morre, e que, neste tempo, a destruição se aproxima de Roma: os cidadãos lutarão contra cidadãos, e assim, extenuados e exangues, serão presa fácil de um rei ou de uma nação - de outra maneira nem o mundo inteiro nem todos os povos coligados seriam capazes de destruir ou abater este império. 3. Devem pois serem firmadas, acima de tudo, as vantagens da concórdia e repudiados os males da discórdia. 4. Isto ocorrerá se reprimires a o excesso de luxo e de roubo, não reclamando as antigas instituições (que são, há muito tempo, por causa da corrupção dos costumes, alvo de escárnio), mas determinando a cada um o limite de despesas de acordo com seu patrimônio familiar”. 
Ep. ad Caes. I, 6.3 quare capesse, per deos, rem publicam et omnia aspera, uti soles, peruade. namque aut tu mederi potes aut omittenda est cura omnibus. 4. neque quisquam te ad crudeles poenas aut acerba iudicia inuocat, quibus ciuitas uastatur magis quam corrigitur.

Ep. ad Caes. I, 6.3 “Portanto ocupa-te - pelos deuses! - da república e, como é de teu costume, enfrenta até o fim todas as dificuldades, já que somente tu podes remediá-la, ou ninguém mais se atreverá a isto. 4. Não há ninguém que te peça seres cruel nos castigos ou rígido nos julgamentos, maneiras pelas quais a cidade não é reformada, mas destruída. Deves afastar da juventude as más condutas e os desejos perversos”.

Ep. ad Caes. II, 6.2 Equidem ego sic apud animum meum statuo, malum facinus in se admittere, qui incommodo reipublicae gratiam sibi conciliet: ubi bonum publicum etiam priuatim usui est, id nero dubitare adgredi, socordiae, atque ignauiae duco.

Ep. ad Caes. II, 6.2 “No entanto, tenho a convicção de que admite um grande crime aquele que obtem o reconhecimento por meio da desgraça da república; mas quando o bem público também é usado como privado, duvidar em atacar é, como realmente penso, preguiça e indolência”.

Ep. ad Caes. II, 7.1 Hostem aduersum deprimere, strenuo homini haud difficilest; occulta pericula neque facere neque uitare bonis in promtu est. 2. Igitur, ubi eos in ciuitatem adduxeris, quoniam quidem reuocata plebs erit, in ea re maxume animum excerceto ut colantur boni mores, concordia inter ueteres et nouos coalescat.

Ep. ad Caes. II, 7.1 "Não é difícil para o homem perseverante derrotar o inimigo à sua frente: cabe aos bons não provocar nem evitar os perigos ocultos; 2. assim, quando os trouxeres à cidade, e assim ter verdadeiramente renovado a plebe, empenha maximamente o ânimo na tarefa de aumentar a concórdia entre os mais velhos e os novos, a fim de se 
cultivarem os bons costumes”.

Ep. ad Caes. II, 8.1 Sed de magistratibus creandis haud mihi quidem absurde placet lex, quam Caius Gracchus in tribunatu promulgauerat; ut ex confusis quinque classibus sorte centuriae uocarentur. 2. Ita coaequatur dignitate, pecunia, uirtute anteire alius alium properabit. 3. Haec magna remedia contra diuitias statuo.

Ep. ad Caes. II, 8.1 "Mas para a eleição dos magistrados e para mim, de fato, agrada muitíssimo a lei, que C. Graco promulgara como tribuno, para serem convocadas ao acaso as centúrias, dentre as cinco classes indistintas. 2. Assim equilibrar-se-ão a riqueza à dignidade e um terá pressa para se sobrepor ao outro em virtude. 3. Este é, penso eu, o grande remédio contra as riquezas, pois do mesmo modo tudo será louvável e conveniente de acordo com seu proveito. A maldade é levada a cabo devido aos proventos: quando a tiveres eliminado, ninguém será mau gratuitamente”.

Ep. ad Caes. II, 10.4 Equidem ego sic apud animum meum statuo: cuicumque in sua ciuitate amplior illustriorque locus, quam aliis est, ei magnam curam esse reipublicae. 5. Nam ceteris, salua urbe, tantummodo libertas tuta est; qui per uirtutem sibi diuitias, decus, honorem pepererunt, ubi paullum inclinata respublica agitari coepit, multipliciter animus curis, atque laboribus fatigatur; aut gloriam, aut libertatem, aut rem familiarem defensat: omnibus locis adest, festinat; quanto in secundis rebus florentior fuit, tanto in aduorsis asperius, magisque anxie agitat.

Ep. ad Caes. II, 10.4 "Por isso, na minha opinião, a qualquer pessoa que ocupe um lugar superior e mais ilustre do que outras em sua cidade, cabe-lhe ter cuidado pela república; 5 . porque, quando outros mantem a república a salvo, apenas a liberdade é preservada. Aqueles que, por meio da virtude, granjearam riquezas, glória, honra para si, mal começa a república a ser perturbada, multiplicadamente começam a ter o ânimo fatigado por causa das 
preocupações e dos esforços: ou defendem a glória, ou a liberdade, ou o patrimônio, apressam-se e se apresentam em todos os lugares. Quanto mais florescentes na sorte, tanto mais espinhosos nas adversidades, inquietando-se com mais desassossego”.

Ep. ad Caes. II, 12.4. Sed me illa magis cupido exercet, uti quocumque modo, et quam primum respublica adiuuetur. 5. Libertatem gloria cariorem habeo. Atque ego te oro, hortorque, ne clarissumus imperator, gallica gente subacta, populi romani summum atque inuictum imperium tabescere uetustate, ac per summam discordiam dilabi, patiaris.

Ep. ad Caes. II, 12.4. "Mas o que mais me persegue é o desejo de que salves a república de qualquer maneira. 5. A liberdade é algo mais caro para mim do que a glória, e eu te peço e te aconselho, eminentíssimo imperador, que, vencida a gente gálica, não permitas que se dissolva pela decrepitude o império sumo e invicto do povo romano, nem que decline pela maior das imprudências”.

Ep. ad Caes. II, 13.3. Pro his amplissumis beneficiis non flagitium a te, neque malum facinus, petimus; sed uti libertatem euersam restituas: 4. qua re patrata, profecto per gentes omnes fama uirtutis tuae uolitabit. 5. Namque hac tempestate, tametsi domi militiaeque praeclara facinora egisti, tamen gloria tua cum multis uiris fortibus aequalis est: si uero urbem amplissumo nomine, ex maxumo imperio, prope iam ab occasu restitueris, quis te clarior, quis maior in terris fuerit?

Ep. ad Caes. II, 13.3. “Por tais amplíssimos benefícios não te pedimos uma ação má, e sim que restituas a liberdade perdida. 4. Tendo concluído isso, sem dúvida alguma a fama da tua virtude vagará por todos os povos. 5 . Com efeito nesta tempestade, mesmo tendo realizado grandes ações na paz e na guerra, tua fama é igual à de muitos homens corajosos. Se restituíres à cidade seu nome amplíssimo e seu maior império, já próximo do ocaso, quem terá sido mais ilustre, quem terá sido maior?” 
Os trechos acima resumem as virtudes que César possui para agir, as circunstâncias em que deve agir e o resultado de suas ações como é esperado de um imperador (cp. Wirszubski, 2004, p.107-123). Num grupo social corrupto pela busca do poder e pelo uso do que é público como privado $^{114}$, o perigo da guerra civil torna-se inevitável e ainda mais grave devido à ausência de ameaça externa ${ }^{115}$. Somente César está apto para dirimir o perigo de um conflito armado porque é sábio e experiente ${ }^{116}$, benigno e clemente ${ }^{117}$. Seu dever é restituir a liberdade perdida ${ }^{118}$ por meio da promoção da paz e da recusa à violência civil ${ }^{119}$ a fim de moralizar seus concidadãos e promover a concórdia ${ }^{120}$. Para tanto, não pode se valer das instituições antigas ${ }^{121}$ e constituir ele mesmo um exemplo para poder imperar sobre os demais ${ }^{122}$, uma vez que está numa posição superior a eles ${ }^{123}$ pelas riquezas que acumulou honradamente ${ }^{124}$ e porque demonstra valor e coragem sobretudo na adversidade ${ }^{125}$; somente por tais razões César é digno de honra e glória ${ }^{126}$.

Disso deriva que o imperator, como comandante de um exército, converta-se num condutor de homens também na vida civil, domi militiaeque. O vocábulo sanciona o consenso que o governante deve promover em relação aos súditos, evitando ainda formalizar a hierarquização e a submissão que outros termos insinuam (rex, tyrannus). César passa a ser tido como imperator na

114Ep. ad Caes. II, 6.2 ubi bonum publicum etiam priuatim usui est, id uero dubitare adgredi, socordiae, atque ignauiae duco.

115Ep. ad Caes. I, 5.2 ciues cum ciuibus manus conserturos, ita defessos et exsangues regi aut nationi praedae futuros; II, 12.5. Libertatem gloria cariorem habeo. Atque ego te oro hortorque, ne clarissumus imperator, gallica gente subacta, populi romani summum atque inuictum imperium tabescere uetustate, ac per summam discordiam dilabi, patiaris.

116Ep. ad Caes. I 2.1 quo melius faciliusque constituas.

117Ep. ad Caes. I 3.3 qui benignitate et clementia imperium temperauere; I 6.4 neque quisquam te ad crudeles poenas aut acerba iudicia inuocat, quibus ciuitas uastatur magis quam corrigitur.

118Ep. ad Caes. II 13.3 Pro his amplissumis beneficiis non flagitium a te, neque malum facinus, petimus; sed uti libertatem euersam restituas: 4. qua re patrata, profecto per gentes omnes fama uirtutis tuae uolitabit; II 10.5 Nam ceteris, salua urbe, tantummodo libertas tuta est.

119Ep. ad Caes. I 1.8 firmanda res publica [...] pacis bonis artibus; I 5.3 firmanda igitur sunt <uel maxime> concordiae bona et discordiae mala expellenda; I 6.3 quare capesse, per deos, rem publicam et omnia aspera, uti soles, peruade. namque aut tu mederi potes aut omittenda est cura omnibus.

120Ep. ad Caes. II 7.2 uti colantur boni mores, concordia inter ueteres et nouos coalescat; II 8.2 Ita coaequatur dignitate, pecunia, uirtute anteire alius alium properabit.

121Ep. ad Caes. I 5.4 id ita eueniet, si sumptuum et rapinarum licentiam dempseris, non ad uetera instituta reuocans, quae iam pridem corruptis moribus ludibrio sunt.

122Ep. ad Caes. I 1.6 cum ipse bonus atque strenuus sis, uti quam optimis imperites.

123Ep. ad Caes. II 10.4 cuicumque in sua ciuitate amplior illustriorque locus, quam aliis est, ei magnam curam esse reipublicae.

124Ep. ad Caes. II 10.5 qui per uirtutem sibi diuitias, decus, honorem pepererunt, ubi paullum inclinata respublica agitari coepit, multipliciter animus curis, atque laboribus fatigatur.

125Ep. ad Caes. II 10.5 quanto in secundis rebus florentior fuit, tanto in aduorsis asperius, magisque anxie agitat.

126Ep. ad Caes. II 10.5 aut gloriam, aut libertatem, aut rem familiarem defensat: omnibus locis adest, festinat. 
medida em que sua ação política se baseia na auctoritas revestida de priuato consilio (Magdelain, 1947, pp. 21 et seq.; Wiederman in Rowe and Schofield [org.], 2005, p. 521; cf. Tác. Hist. I 1), e nisso suas ações não cabem mais na república romana tal como vinha sendo concebida.

Tratando da natureza dos conflitos civis, Tácito justifica o principado como uma necessitas frente à decadência dos costumes (Kivuila-Kiaku, 2003, p. 145), e testemunha a impossibilidade da república segundo ela havia sido identificada por Cícero (Tac. Ann, IV, 33 Nam cunctas nationes et urbes populus aut primores aut singuli regunt: delecta ex iis et consociata rei publicae forma laudari facilius quam evenire, vel si evenit, haud diuturna esse potest; "Pois a todas as nações e cidades regem ou o povo, ou os mais eminentes ou um só, pois a forma de uma república escolhida e constituída por estes três é mais fácil ser louvada do que efetivar-se, ou, se se efetuasse, pouco poderia durar”), ao ver na decadência dos costumes a raíz dos problemas que destruíram essa constituição:

Hist. II 38. 2. Sed ubi subacto orbe et aemulis urbibus regibusue excisis securas opes concupiscere uacuum fuit, prima inter patres plebemque certamina exarsere. 3. Modo turbulenti tribuni, modo consules praeualidi, et in urbe ac foro temptamenta ciuilium bellorum; mox e plebe infima C. Marius et nobilium saeuissimus L. Sulla uictam armis libertatem in dominationem uerterunt. 4. Post quos Cn. Pompeius occultior non melior, et numquam postea nisi de principatu quaesitum. 5. Non discessere ab armis in Pharsalia ac Philippis ciuium legiones, nedum Othonis ac Vitellii exercitus sponte posituri bellum fuerint: eadem illos deum ira, eadem hominum rabies, eaedem scelerum causae in discordiam egere. 6. Quod singulis uelut ictibus transacta sunt bella, ignauia principum factum est. 7. Sed me ueterum nouorumque morum reputatio longius tulit: nunc ad rerum ordinem uenio.

Hist. II 38. 2. "Mas, quando o mundo foi submetido e foram derrubadas as cidades e os reis rivais, nada mais houve o que fazer senão garantir riquezas, e surgiram as primeiras lutas 
entre senado e plebe. Agora tribunos sediciosos, então cônsules usurpadores, e na cidade e no foro surgiram conflitos entre civis. Pouco depois Mário, oriundo de uma plebe minúscula, e o crudelíssimo Sula, dentre os nobres, verteram com armas a liberdade em dominação. Depois desses, Cneu Pompeu não foi mais insensível nem melhor, e depois dele nunca mais houve conflito que não fosse por poder. Legiões civis não depuseram as armas em Farsália e em Filipos, nem os exércitos de Oto e de Vitélio espontaneamente cessaram a guerra: a mesma ira divina, o mesmo ódio humano, as mesmas razões dos crimes careciam de uma guerra. Foi por causa da covardia dos comandantes que as guerras acabaram uma a uma de uma só vez. Mas a reputação dos costumes dos antigos e dos contemporâneos me levou longe demais: volto agora ao tema em pauta”.

Já Salústio (Bel. Cat. 2.1-9; 11.5; Bel. Iug. 2.1 - 3.4; 41.2) e Tito Lívio (Ab urbe cond. Praef. 9-10; 39.6), entre os historiadores, haviam sinalizado os perigos da decadência dos costumes. Com efeito, o conteúdo esquemático desse processo, tal como é normalmente descrito (ambição + introdução de novidades + falta de controle moral = degeneração da constituição), atende à conveniência de se resgatar o passado com o intuito de cumprir aquilo que Cícero denomina historia magistra vitae (De Or. II 9, 35), i.e, oferecer às gerações futuras uma visão conservadora do passado através de exempla de virtudes, com vistas à formação do caráter do indívíduo e à preservação do mos maiorum (cf. Wiederman in Rowe and Schofield [org.], 2005, p. 517). Nesse sentido, a decadência dos costumes serve de argumento para a manutenção do status quo e por isso mesmo é essencial tanto para a educação do indivíduo que se quer lançar à vida pública, quanto para ratificar os valores sobre os quais a própria constituição se sustenta. Não por acaso, a decadência dos costumes é um tema que varia pouco na historiografia romana, pois, se as causas podem mudar (a predileção pelo luxo e o descrédito da austeridade em Salústio e em Lívio, as guerras civis e a submissão senatorial em Tácito), o resultado será sempre o mesmo, enxergado escatologicamente como o fim do mundo sem o poderio romano. Ademais, a decadência dos 
costumes desvia a atenção do indivíduo para a busca da glória na desonra e no lucro fácil, mas a atenção que o historiador presta aos sintomas dessa decadência inclui-o no número de homens probos. Dessa forma, o relato histórico ganha autoridade para incentivar o indivíduo a buscar a glória e a fama - e o historiador, para exortar sua audiência a buscar essas virtudes (Funari in Joly [org.], 2007, p. 73).

No caso específico das Ep. ad Caes., a decadência dos costumes fixa o ponto a partir do qual o conselho pode ser dado, ou seja, empresta fides (credibilidade) ao orador, que se vale de um tema caro aos historiadores a fim de constituir a sua própria persona no e pelo discurso. O tema é, além disso, conveniente para um texto escolar, uma vez que a virtude não é inteiramente natural ao homem, devendo ser objeto de instrução (Quint. Ins. Or. I 1.36; II 20.6-7; XII 2.1; Morgan, 1998, p. 228). A grandeza dos antepassados, que se opunha à decadência dos costumes e servia de ponto de partida para a compreensão de onde os romanos começaram simbolicamente a errar, constituía um saber herdado, essencial para o aristocrata romano por confirmar sua posição no grupo, por situar no indíviduo a fonte de reputação e orgulho e, por fim, para garantir uma posição notável que o aristocrata não detinha formalmente (Sebastiani in July [org.], 2007, p. 87). Considerado o orador também um homem público, prescrever o comportamento ideal do governante inclui obrigatoriamente a menção à própria virtude para tornar o indivíduo e o discurso congruentes tanto pela virtude (individual) quanto pela confiabilidade (discursiva) (Cic. Fin. 3.62-8; Quint. Ins. Or. II 20.6-7; Morgan, 1998, p. 232).

Eis, portanto, a razão de o termo imperator ser entendido nas Ep. ad Caes. como designação do monarca. Originalmente, imperator define o comandante que é capaz de manter a disciplina dos seus soldados e exibir no triunfo riquezas abundantes e muitos povos conquistados, i.e., um responsável pela ampliação externa do poderio romano (Sebastiani in Funari [org.], 2007, p. 85). Mas num contexto de promoção da paz interna por meio do sufocamento da guerra civil, de moralização dos próprios concidadãos por meio de ações que demonstrem as virtudes de um indivíduo proeminente e de reestruturação dos ordines para extinguir as lutas pelo poder, o 
imperator deixa de ser aquele que exerce uma magistratura cum imperio para representar a coletividade através do exercício de um poder absoluto.

O termo adquire conotação positiva, por exemplo, em Tácito, para quem imperium é o oposto de dominatio (cp. Ep ad Caes. I 2,3 particeps dominationis; Ep ad Caes. II 3,6 Sed homines inertissimi, quorum omnis uis uirtusque in lingua sita est, forte atque alterius socordia dominationem oblatam insolentes agitant; "Porém os homens mais covardes, dos quais toda a força e virtude estão situadas na língua, promovem, insolentes, uma dominação imposta pela ventura e fraqueza de outrem" e Ep ad Caes. II 4,3 Neque illis tantae uoluptati est, tametsi insperantibus accidit, dominatio quanto maerori tua dignitas; "Não possuem maior desejo de poder - embora esse lhes venha sem esperarem - do que inveja”), o que já fica evidente nos Ann. I 1 non Cinnae, non Sullae longa dominatio; et Pompei Crassique potentia cito in Caesarem, Lepidi atque Antonii arma in Augustum cessere, qui cuncta discordiis ciuilibus fessa nomine principis sub imperium accepit ("Nem foi longo do domínio de Cina e Sula, e o poder de Crasso e de Pompeu passou logo para as mãos de César; as guerras de Antônio de Lépido cessaram sob Augusto, o qual, depois de tudo destruído por conta das guerras civis, aceitou sob seu o poder de general a designação de príncipe”) e nas Hist. II 38.3 mox e plebe infima C. Marius et nobilium saeuissimus L. Sulla uictam armis libertatem in dominationem uerterunt ("Pouco depois Mário, oriundo de uma plebe minúscula, e o crudelíssimo Sula, dentre os nobres, verteram com armas a liberdade em dominação”). Segundo Kivuila-Kiaku (2003, p. 147), dominatio pressupõe uma degradação do poder (em especial depois das guerras civis), enquanto imperium denomina o poder que tratou de recuperar a paz - esse ligado à pessoa de Augusto, aquele à de Sula. O que existe aqui é, novamente, a oposição entre princeps (aquele que exerce o imperium) e o tyrannus (aquele que exerce a dominatio).

Como implicação direta da decadência dos costumes, a perda da libertas se alia à natureza do poder tirânico: mox e plebe infima C. Marius et nobilium saeuissimus L. Sulla uictam armis libertatem in dominationem uerterunt (Hist. II 38.3 "Pouco depois Mário, oriundo de uma plebe 
minúscula, e o crudelíssimo Sula, dentre os nobres, verteram com armas a liberdade em dominação”). Para Tácito, libertas e dominatio se opõem porque o governante é um tirano, o que desloca o problema da perda desta libertas não ao principado como forma de constituição, mas àquele que exerce o poder (Kivuila-Kiaku, 2003, pp. 152 et seq.). Em que pese a conduta do governante em relação aos governados, a libertas pode existir unicamente quando o governante exerce o imperium, ou seja, quando a constituição pode ser identificada como o principatum: Nerua Caesar res olim dissociabilis miscuerit, principatum ac libertatem, augeatque cotidie felicitatem temporum Nerua Traianus (Vita Agr. 3,1 "Nerva César uniu duas coisas outrora diferentes: o principado e a liberdade, e Nerva Trajano a todo momento aumenta a boa ventura destes nossos tempos”).

Assim é que, nas Ep. ad Caes., o termo imperator recebe conotação positiva porque referese a um líder cuja moderação o orienta a agir com benignidade e clemência (Ep. ad Caes. I 3,3 contra qui benignitate et clementia imperium temperauere; “Quem, ao contrário, abrandou o poder com benignidade e clemência”) e a demonstrar compreensão e sabedoria (Ep. ad Caes. I 2,1 Sed iam, quo melius faciliusque constituas; "Mas agora, para que melhor e mais facilmente decidas”), tendo como dever restituir a liberdade perdida (Ep. ad Caes. II 13,3 sed uti libertatem euersam restituas; “que restituas a liberdade perdida”). Ele é um clarissimus uir (cp. II 12,4 clarissimus imperator; II 13,6 quis te clarior), e nisso contempla a definição do imperador como um mandatário da coletividade, um cidadão devotado que assume os assuntos públicos, que luta para proteger os concidadãos e que é eleito pelo acordo consensual do senado e do exército (cp. Corpus Inscr. Lat. XV, 7505; Tac. Hist. I 17; Veyne, 2005, p. 15-18). Tal responsabilidade é, nos documentos aqui analisados, reafirmada pelo conselho dado a esse chefe, uma vez que sua posição de proeminência é legitimada unicamente pelo consenso do povo romano por ele promovido (cp. Aug. Res Gestae 34; Tac. Hist. I 30,2; Suet. Cal. XIV 1; Pl. Pan Tr. X 2; Veyne, 2005, p. 23) .

A historiografia e o relato biográfico romanos do período imperial mais de uma vez louvaram a clemência e a moderação de César. Esse louvor se deve, em parte, às suas ações após a 
guerra civil e, em parte, às reformas que promoveu como dictator. Assim ele é lembrado por Suetônio (Caes. 75 Moderationem vero clementiamque cum in administratione tum in victoria belli civilis admirabilem exhibuit; “com efeito, demonstrou admirável moderação e clemência tanto na condução quanto na vitória da guerra civil”) e por Veleio Patérculo (Hist. Rom. II 55, 2 nec dissimilis ibi adversus victos quam in priores clementia Caesaris fuit; "a clemência de César não foi ali diferente, estando ele contra os inimigos, do que em relação aos anteriores”). Entretanto, César é também lembrado como um exemplo de autocrata que tentou se apropriar sozinho de todo o poder, e condenado exatamente pela responsabilidade sobre a perda da libertas e pelo exercício da dominatio. Assim ele é retratado pelo mesmo Veleio Patérculo (Hist. Rom. II 57, 1 Laudandum experientia consilium est Pansae atque Hirtii, qui semper praedixerant Caesari ut principatum armis quaesitum armis teneret; "É de se louvar, pela experiência, o conselho de Pansa e de Hírtio, que sempre lembraram a César que ele obtinha com armas o poder buscado com armas”), por Floro:

II 12,92 Quae omnia uelut infulae in destinatam morti uictimam congerebantur. Quippe clementiam principis uicit inuidia, grauisque erat liberis ipsa beneficiorum potentia. 93 Nec diutius lata dominatio est, sed Brutus et Cassius aliique patres consensere in caedam principis.

II 12,92 “No entanto, tais honras foram como as insígnias acumuladas por uma vítima destinada à morte. Com efeito, a inveja venceu a clemência do príncipe, e o próprio poder com o qual concedia favores era insuportável para os cidadãos livres. 93. A dominação que lhe foi outorgada não durou por muito tempo, pois Bruto, Cássio e outros senadores uniramse em conluio para matar o príncipe”.

por Suetônio, que é condescendente com a postura que César teria adotado após a vitória na guerra civil: 
Caes.76 Praegravant tamen cetera facta dictaque eius, ut et abusus dominatione et iure caesus existimetur. non enim honores modo nimios recepit: continuum consulatum, perpetuam dictaturam praefecturamque morum, insuper praenomen Imperatoris, cognomen Patris patriae, statuam inter reges, suggestum in orchestra; sed et ampliora etiam humano fastigio decerni sibi passus est: sedem auream in curia et pro tribunali, tensam et ferculum circensi pompa, templa, aras, simulacra iuxta deos, pulvinar, flaminem, lupercos, appellationem mensis e suo nomine; ac nullos non honores ad libidinem cepit et dedit.

Caes. 88 Periit sexto et quinquagensimo aetatis anno atque in deorum numerum relatus est, non ore modo decernentium, sed et persuasione volgi. siquidem ludis, quos primo[s] consecrato[s] ei heres Augustus edebat, stella crinita per septem continuos dies fulsit exoriens circa undecimam horam, creditumque est animam esse Caesaris in caelum recepti; et hac de causa simulacro eius in vertice additur stella. Curiam, in qua occisus est, obstrui placuit Idusque Martias Parricidium nominari, ac ne umquam eo die senatus ageretur.

Caes. 76 “Todavia, outros feitos e ditos dele [César] o denegriram, de modo que pensam que ele abusou do poder e com razão foi assassinado. De fato, recebeu bastantes honras ilimitadamente: consulados sucessivos, a ditadura perpétua e o regulamento dos costumes, sem contar o prenome de imperador, o sobrenome de pai da pátria, uma estátua entre as dos reis e o assento mais importante no teatro. Aceitou ainda que lhe cedessem coisas muito acima da condição humana: um assento de ouro no senado e no tribunal, um carro e um andor na procissão circense, templos, altares, estátuas entre as dos deuses, um pulvinar, um flâmine, lupercos e um mês com seu nome; e tanto tomou quanto entregou cargos segundo sua vontade”.

Caes. 88 "Morreu aos cinquenta e seis anos de idade e foi colocado entre os deuses não por decreto do senado, mas por vontade do povo. De fato, enquanto seu herdeiro Augusto celebrava os primeiros jogos consagrados a ele, um cometa, que surgiu por volta das onze horas, começou a brilhar por sete dias consecutivos e acreditou-se que era a alma de César 
recebido nos céus - por isso ele é representado com uma estrela sobre a testa. Ficou decidido que a cúria, onde foi assassinado, fosse cercada de muros, que os idos de março fossem chamados de “dia parricida” e que o senado não se reunisse nesse dia”.

e, enfim, por Eutrópio, para quem César começou a agir insolentemente após a vitória na guerra civil e quis se sobrepor ao senado, agindo portanto como um tirano:

Eutr. Brev. VI 25 Inde Caesar bellis civilibus toto orbe conpositis Romam rediit. Agere insolentius coepit et contra consuetudinem Romanae libertatis. Cum ergo et honores ex sua voluntate praestaret, qui a populo antea deferebantur, nec senatui ad se venienti adsurgeret aliaque regia et paene tyrannica faceret, coniuratum est in eum a sexaginta vel amplius senatoribus equitibusque Romanis. Praecipui fuerunt inter coniuratos duo Bruti ex eo genere Bruti, qui primus Romae consul fuerat et reges expulerat, et C. Cassius et Servilius Casca. Ergo Caesar, cum senatus die inter ceteros venisset ad curiam, tribus et viginti vulneribus confossus est.

Eutr. Brev. VI 25 “Por isso, após as guerras civis, César retornou a Roma tendo subjugado o mundo inteiro. Começou a agir de maneira muito insolente e contra o costume romano de ser livre. Mas ao entregar cargos segundo sua vontade - o que era antes uma prerrogativa do povo -, não apresentar-se aos senadores, que vinham até ele, e promover ações de um rei ou mesmo de um tirano, foi vítima de uma conjuração de mais de sessenta senadores e cavaleiros romanos. Entre os conjuradores, sobressaíram-se os dois Brutos - descendentes da família do mesmo Bruto que expulsou os reis de Roma e se tornou o primeiro cônsul -, Caio Cássio e Servílio Casca. Tendo naquele dia César vindo ao senado no meio da multidão, foi assassinado com vinte e três golpes”.

Isso pode sugerir uma série de tópicos para o aconselhamento nos exercícios de formação do 
orador (promover a concórdia e o consenso, deter o apego aos bens materiais, por termo à ganância etc.). Uma vez que esses exercícios estão comprometidos com a formação do cidadão e, no limite, iniciá-lo nos valores daquilo que se poderia chamar "cultura política” (porque envolve uma série de padrões de comportamento encerrados no mos maiorum e que resultam nos atributos a serem demonstrados na escalada do cursus honorum), as lições da história transformariam César num modelo de governante cujo exemplo deve ser aprimorado a partir do aconselhamento para a realização daquilo que ele não fez ou, se fez, poderia ter feito melhor, a fim de não resultar no tipo de morte de que foi vítima. Insistir sobre a clemência e sobre a moderação pode, disfarçando a preocupação com a fortuna do imperator, reforçar a noção do consensus, que é importante para o ingresso do cidadão na vida pública, e dar garantias para que ele desenvolva sua carreira tendo o exemplo do que lhe pode suceder ao ultrapassar os limites dados para a sua atuação.

A teorização do poder, no primeiro século do principado, assenta-se, portanto, na legitimidade conferida pela aristocracia à pessoa do imperador. Esse, por sua vez, é um magistrado cuja posição está assegurada graças a um programa de restauração ou de conservação da república, tanto no âmbito moral quanto no jurídico. Sua posição é garantida na medida em que ele reconhece e promove o consensus e a concordia tal como esses conceitos haviam sido formulados em fins do período republicano (Briquel in Inglebert, 2002, pp. 165-166). Assim, com base no curto período entre as guerras civis e a ascensão de Augusto, a aristocracia romana (representada primeiramente por Cícero e muito depois por Sêneca e por Tácito) decide, comprimida pela necessidade de reestruturar-se, quais as prerrogativas para o exercício do poder; calcula os limites da ação do imperador, por meio do estabelecimento de virtudes específicas a serem demonstradas em relação aos seus concidadãos; fornece um contexto específico para o exercício do poder e para o uso da experiência política a fim de disseminá-los dentro da comunidade e, por fim, reforça-os e perpetuaos (cf. Lobur, 2008, p. 4-8; 13; 19-20; 40-42; 48-50; 90-93). A educação do homem público é um passo fundamental nesse sentido. 


\section{Capítulo 2 - Disposição e elocução nas Epistulae ad Caesarem}

\section{De materia artis}

Porque o conselho é dado a uma pessoa em particular e a matéria das Ep. ad Caes. concerne ao útil, esses documentos pertencem ao gênero deliberativo (Quint. Inst. Or. III 4, 16; III 8, 22). A questão (Quint. Inst Or. III 5,7; III 7,3; III 8,4; III 8,35; Cíc. De inv. I 6.8; I 13.18), ou antes, o objeto sobre o qual o aconselhador argumenta, trata do que César deve fazer em relação à administração da república antes e depois do conflito civil. Quanto ao ponto discutido, a questão é de qualidade (Hermágoras apud Quint. Inst. Or. III 6, 56-57) definida ou especial (Quint. Inst. Or. III 5, 7-10). Nas Ep. ad Caes., entretanto, o gênero deliberativo avizinha-se do gênero demonstrativo em função do elogio das virtudes que César possui para agir durante a administração da república. Na análise dos documentos, seguirei pari passu as prescrições de Quintiliano (em especial) e, secundariamente, da Retórica a Herênio e de Cícero pois, não obstante as mencionadas características, os documentos apresentam a arte do orador ao responder aos requisitos do ofício de aconselhar (Quint. Inst. Or. III 8, 15-16) conforme a matéria da deliberação, a natureza de quem está envolvido na discussão e a natureza de quem oferece o conselho, mencionados pelos referidos autores.

Justificam a matéria útil nas Ep. ad Caes. as passagens I 8.7 (com base no que foi apresentado em I 3.1; I 5.1 - 7.5), II 12.3 e II 13.8 (com base no que foi apresentado em II 7.2-12; II 8.1-3; II 10.1 - 12.8); a questão definida ou especial, demonstram-na as passagens I 2.1-4; I 4.1-4 e II 3.1 - 6.1, de que se aduz que a ação futura (I 5.1; 3-8; I 6.1-4; I 7.1-3; I 8.4-6; II 7.1-3; II 8.1; II 
12.4) é uma ação externa que influa de maneira decisiva no curso da História (I 3.1; II 13.3-6), porque se orienta pela equidade e pela sabedoria (I 1.4-8; II 1.5; II 2.1-4).

Trata, pois, a matéria útil, na primeira epístola, do salvar e preparar a república para o futuro através das vantagens da paz (I 1.8). Salvar a república, porque aqueles que se opuseram a César o injuriaram, não usaram de raciocínio próprio ao se lançarem à guerra e se deixaram levar ou por questões de parentesco, ou por corrupção de caráter ou por terem feito dívidas, e por tais razões serviram-se do apoio a Pompeu, homem ambicioso e mais dotado de sorte, que de razão (I 2.1-7). Preparar a república para o futuro através das vantagens da paz, porque César deve inicialmente firmar as vantagens da concórdia e repudiar os males da discórdia, por meio da repressão da liberdade de gastos e do excesso de furtos, determinando a cada família o limite de suas despesas de acordo com seu patrimônio (I 5.3-4); depois, afastar da juventude as más condutas e os desejos perversos (I 6.4; 7.2) e impedir que os cidadãos abandonem a Cidade, culpados ou não (I 6.4); tomar providências para que a plebe faça seus negócios sem contribuir para a calamidade pública (I 7.2); evitar que os magistrados sejam alvo de corrupção (I 8.3); livrar a Itália e as províncias de perturbações (I 8.4) e, por fim, reconhecer de maneira justa os méritos dos soldados (I 8.6). Tais ações são, ao mesmo tempo, necessárias à república, considerando o momento anterior à guerra (I 4.1-4), e motivo de glória para César (I 8.7), pois que este líder é benigno, clemente (I 1.6; I 3.3; I 6.4), sábio (I 6.1-4) e valoroso (I 1.10; I. 7.1).

Trata, ainda, a matéria útil, na segunda epístola, do proceder quanto aos assuntos urbanos em meio à guerra (II 2.3; 4.4). Isso porque Cneu Pompeu desconcertou a república, entregando a uns poucos senadores o sumo poder de administrar os impostos, os gastos públicos e as decisões judiciais. Esses fazem e desfazem o que querem, perseguem inocentes, favorecem apenas amigos e familiares, praticam toda sorte de crimes para obter cargos e desprezam as leis (II 3.1-5; 4.2). Por outro lado, Pompeu aprovou outras leis que sufocaram a plebe (II 4.2). Os procedimentos mais aconselháveis serão (II 7.2 et seq.) aumentar a concórdia entre os mais velhos e os mais novos nas colônias (II 5.8; 7.2), eliminar a ganância de riquezas (II 7.3-10; 8.5), equilibrar a eleição de 
magistrados equiparando bens e virtudes de cada um (II 7.11; 8.1-2). Em relação ao senado (II 10.1 et seq.), aumentar o número de senadores, eleger pretores e cônsules conforme a dignidade daqueles que pleiteiam o cargo (II 8.10) e promover o voto secreto (II 11.5-7; 12.1) a fim de aumentar a competência que o senado deveria ter para julgar e para submeter a plebe (II 10.6; 11.1), impedindo a decrepitude do poder romano (II 12.5). Tais ações servem para restituir a liberdade perdida e garantir à cidade seu renome e império (II 13.3; 5). Somente César apresenta as qualidades necessárias para isso (II 4.3-4; 13.1-2), como o sejam a dignidade (II 1.4), a coragem e a generosidade (II 1.5-6), a virtude (II 2.3), a sabedoria, a moderação (II 2.4), a glória (II 12. 5; 13. 46) e porque possui uma riqueza honesta (II 13.2).

Em ambas as epístolas, a matéria pode ser tratada como quaestio finita (Quint. Inst. Or. III 8, 14; Cic. De Or. II 82, 333 et seq.) dada a indicação concreta de personagens e alvo das ações e, em relação à complexidade do problema, como quaestio simplex (Quint. Inst. Or. III 8, 18) dada a deliberação sobre a própria matéria. O momento temporal é o futuro, recorrendo-se às vezes ao passado e ao presente para justificar a deliberação. Já o exórdio de ambas (I 1.4-8; II 2.2) traz a qualitas que introduz o status coniecturae (an faciendum/an fieri possit) (Quint. Inst. Or. III 8, 16)

e as virtudes morais de César põem em contato o status coniecturae e o status qualitatis. A auctoritas do orador em relação ao aconselhamento é posta amiúde à prova em I 2.1; I 2.7; I 3.2-4; I 5.2; I 5.5-8; I 6.2-4; I 7.1; I 7.4-5; I 8.1-3; I 8.10; II 1.1-5; II 2.1-2; II 3.5; II 3.7; II 4.3-5; II 5.1; II 5.7-8; II 6. 1-2; II 7.1; II 7.4-9; II 8.1-4; II 9.1-4; II 10.1-9; II 11.2-4; II 12.2-8; II 13.8.

Ao analisar a disposição e a elocução das Ep. ad Caes., com base na matéria e no gênero delas, e compará-las às obras de Salústio, meu intuito é verificar em que medida esses documentos imitam a obra do historiador no que se refere ao estilo.

\section{De parte artis}

Das seis partes possíveis do discurso - a saber, exórdio, narração, partição, confirmação, 
refutação e peroração (Rhet. ad Her. I. 4: Cíc. De inv. I xiv.19; Part. Or. 27) - a primeira das Ep. ad Caes utiliza cinco partes - exórdio, narração, partição, confirmação e peroração -; a segunda, por sua vez, quatro - exórdio, narração, confirmação e peroração. Ambas combinam elementos do discurso deliberativo àqueles do demonstrativo no exórdio, na narração e na conclusão.

Com o objetivo de estabelecer a credibilidade do discurso (Cíc. De inv. I xv. 20; De or. II. 80; Part. Or. 28; Or. 122; Top. 97; Quint. Inst. Or. IV 1, 5; Lausberg, 1994, §§ 263-288), tornando o ouvinte benévolo, atento e dócil, o exórdio das duas epístolas se vale do elogio a César, precedido da tarefa do orador de captar a benevolência por meio da justificativa da autoridade que possui para aconselhar. Para tanto, na epístola segunda, enuncia razões grandiosas e honestas (Quint. Inst. Or. IV 1, 7), frutos da deliberação e da amizade que tem ao interessado, graças às quais advoga a favor de uma ação. Já na epístola primeira, o orador opta pelo elogio a César, valendo-se de duas qualidades do interessado, a saber, a boa fortuna e a virtude, e depois apresentando-o como honrado e perseguido injustamente pela poderosa parte contrária (cf. Quint. Inst. Or. IV 1, 13-14). Esses procedimentos ab nostra persona somam-se aos outros três existentes para tornar o ouvinte benévolo, atento e dócil (ab nostra, ab adversariorum nostrorum, ab iudicum persona, a causa cf. Cíc. De invent. I 16.22) e devem limitar-se à moderação de afetos do exórdio.

A preceptiva retórica expõe os mesmos procedimentos para o exórdio não do discurso deliberativo, como o sejam as Ep. ad. Caes., mas para o discurso demonstrativo. Atesta-o um dos tratados de retórica de Menandro, o rétor (Tratado II, 368 et seq.), para quem o discurso imperial deve principiar-se por uma amplificação que atribua grandeza ao tema, executada ou pela menção à dificuldade de se tratar de um tema tão difícil, como o seja elogiar alguém de importância superior; ou pela menção à grandeza das próprias palavras, seguidas da experiência prática com a ajuda boa e brilhante da fortuna, a qual, alcançada, resultará em glória para o autor; ou, ainda, pela menção à gratidão resultante dos benefícios de que o imperador fez desfrutar; ou, por fim, a partir de exemplos ilimitados, tais que a finitude do horizonte frente à infinitude da boa fama do imperador. De um modo ou de outro, o exórdio assim constituído confere tom elevado ao discurso, 
semelhantemente à invocação às Musas ou à partição do assunto tratado proximamente e procedimentos que tais, adotados nos demais gêneros.

O engrandecimento presente no exórdio, visando enobrecer a matéria, constitui a acomodação do discurso a uma causa exterior (Rhet. ad Her. III 2). Sua utilidade divide-se em duas partes (Rhet. ad Her. III 3 et seq.): a segura (tuta) e a honesta (honesta). Enquanto a parte segura possibilita evitar os perigos atuais ou iminentes, a parte honesta trata das ações retas e louváveis.

Ações retas são aquelas realizadas com virtude e dever e se subdividem em quatro virtudes: prudência, justiça, coragem e modéstia. No discurso, a prudência é empregada na comparação de vantagens e desvantagens, servindo para exortar ou aconselhar mediante um exemplo; a justiça é empregada para defender os inocentes, os suplicantes, guardar a fé, preservar as leis e os costumes da cidade (o culto religioso e o respeito aos pais, deuses e pátria) e cultivar as alianças e amizades, demonstrando que nem o dinheiro, nem os favores, nem os riscos ou a rivalidade persuadam a tomar o rumo oposto; a coragem é empregada para demonstrar que é preciso perseguir e desejar coisas grandiosas e honestas, e desprezar as coisas baixas e indignas; a modéstia é empregada para vituperar o desejo excessivo das honras, dinheiro e outras benesses que tais, a fim de estabelecer a medida de cada coisa. Todas estas partes devem ser ampliadas, ao aconselhar, ou atenuadas, ao dissuadir. No ataque ao adversário, por exemplo, o que é prudência torna-se inépcia, o que é justiça torna-se covardia, fraqueza e liberalidade torpe, o que é coragem torna-se temeridade e o que é modéstia torna-se inércia e negligência.

Ações louváveis são aquelas que geram lembrança honesta no presente e no futuro e dependem de ações retas para assim serem chamadas. As ações retas e honestas, mesmo que recebam tratamento distinto no discurso, obedecem a uma partição quádrupla, se a razão é honesta e se nela incidirem todas as partes das ações retas, ou outra partição, se na razão honesta não incidirem todas as partes das ações retas. Neste último caso, se o parecer for sustentado pela razão segura sobre a honesta, dever-se-ão utilizar na confirmação e na refutação alguns tópicos; se o parecer for sustentado pela razão honesta sobre a segura, deve-se optar por outros (q.v. Rhet. Ad 
Her. III 8-9).

Quero dizer, com isso, que o exórdio das Ep. ad Caes. obedece aos preceitos de disposição da matéria (q.v. Cíc. De or. II 80; 320-332), elogiando as virtudes do destinatário (Ep. ad Caes. I 1.2; $1.4 ; 1.6-8$ ) e apresentando a figura do orador (Ep. ad Caes. II $1,3-4$ ) de forma a captar a benevolência do auditório. A prosopopeia, tal como definida por Teão (Prog. 115.11.8), é conveniente para essa parte do discurso porque, especificamente no exórdio, existe a necessidade de construção da persona do orador, ou antes, do missivista (Ep. ad Caes I 1.10; II 1.3-4) e existe a referência às virtudes do destinatário, valendo-se dos tópicos da causa honesta (para a prudência, cf. Ep. ad Caes. I 1.2-3 e II 2.3; para a justiça, cf. Ep. ad Caes. I 1.7-8 e II 2.4; para a coragem, cf. Ep. ad Caes. I 1.8-9 e II 1.5; e para a modéstia, cf. Ep. ad Caes. I 1.6 e II 1.4). Ademais, como praxe do gênero deliberativo, o elenco dos tópicos da causa honesta reforça a exortação ou o conselho por meio do movimento das afecções (cf. Cíc. De or. II 337).

Das partes do discurso, a finalidade da narração é estabelecer a credibilidade (Rhet. ad Her. I. 12; Cíc. Part. Or. 31) preparando os argumentos para a confirmação. Em ambas as Ep. ad Caes., são observados os preceitos de serem breves, claras e verossímeis (Rhet. ad Her. I. 14; Cic. Part. Or. 31; De or. II 326-329; Quint. Inst. Or. IV. 2. 40-52), e servem, em geral, para cumprir a utilitas característica do gênero deliberativo $^{127}$.

Defino, pois, como narrativa da primeira epístola, as seções 2. 1-7 e 4. 1-2, enquanto, da segunda epístola, a seção 3. 1 - 4. 5. Nelas, predomina o ataque a Cneu Pompeu, tido ora como general sem capacidade para liderar devido à falta de virtude (Ep. ad Caes. I 2.2), ora como cruel com os concidadãos (Ep. ad Caes. I 4.1), ora como responsável pelo desconcerto da república (Ep. ad Caes. II 3.1) e por isso comparado a Sula (Ep. ad Caes. I 4.1; II 4.1). Na primeira epístola, a

127 Em Rhet. ad Her. I. 12 e Cíc. De inv. I xix, 27, a narração é dividida em três grupos, respectivamente, fabula, historia e argumentum, distintas pelo critério da verdade. Esse mesmo critério separa, nos praexertamina, a fabula da narratio, sendo esta última subdividida em historia e argumentum por Prisciano; já Hermógenes, Aftônio e Nicolau, bem como Cícero (De inv. I xix, 27 supra) parecem seguir uma partição que remonta a Hermágoras (cf. Calboli in Rhet. ad Her., pág. 214, nota 19), dividindo a narração em três grupos: exposição de feitos (cum exponimus rem gestam), digressão para defesa de uma causa (fidei aut criminationis aut transitionis aut alicuius apparationis causa) e exercício para deleite (quod a causa civili remotum est). Esse último grupo, por sua vez, subdivide-se nos três primeiros grupos supracitados - fabula, historia e argumentum. 
primeira narração (2.1-7), por adiantar as ações de César como justas, dada a inépcia de seu adversário na gerência da coisa pública, caracteriza-se como uma exposição do estado da causa, partilhando mais elementos do discurso demonstrativo do que do discurso deliberativo. A segunda narração (4. 1-2), denominada digressão ou epidiegese, de caráter eminentemente declamatório, serve de ornamento ao discurso e deve produzir comiseração ou revolta (q.v. Quint. Inst. Or. IV. 2, 128), e para isso é conveniente sua brevidade. Ocupa, na Ep. ad Caes. II, a tarefa de relembrar ao destinatário as atrocidades cometidas por Pompeu antes da guerra civil.

Na segunda epístola, por sua vez, a narração (3.1 - 4.5) caracteriza-se, ela mesma, como uma digressão, integrando a subespécie da história (Rhet. ad Her. I. 8), tratando, pois, da exposição de eventos passados que desqualificam, novamente, Pompeu para a gerência da coisa pública, mas desta vez vinculando seu nome ao de Sula, lembrado, outrora, como assassino de seus concidadãos.

Entretanto, a considerar a ciência do caso por parte do aconselhador e do aconselhado requisito fundamental para o conselho - a narração seria uma parte do discurso que seria dispensável (q.v. Cíc. De or. II 330-332), caso essas epístolas não configurassem uma peça de exibição do talento do orador. Com efeito, a narração do caso desde seus antecedentes, numa deliberação real, fere a virtude principal dessa parte do discurso, a saber, ser prazerosa e adequada à persuasão, porque ela não seria breve, nem clara, nem verossímil (q.v. Cíc. ibid.). Tratadas as duas Ep. ad Caes., contudo, como exercício, a narração constitui fonte para todo o resto do discurso, porque fundamenta a demonstração do caso (Cíc. De or. II 330), função própria da confirmação.

No discurso, cada parte se destina a algo específico (Cíc. Part. or. 27): mover o ânimo (mouere) ou estabelecer a credibilidade do discurso (fides); àquele primeiro objetivo, destinam-se o exórdio e a peroração e a este último, destinam-se a narração e a confirmação.

Uma vez que a matéria das Ep. ad Caes. concerne ao útil e a questão seja de qualidade definida ou especial, considero a confirmação (q.v. Cíc. De inv. I xxiv.34; Quint. Inst. Or. IV 2, 79) composta de provas artísticas (objeto específico de análise no capítulo anterior, porque pertencentes ao domínio específico da invenção) (q.v. Quint. Inst. Or. V. 1, 1) aduzidas ética e pateticamente. 
$\mathrm{Na}$ primeira epístola, as provas patéticas relacionam-se ao que César deve fazer para a conclusão da guerra (3.1 - 3.4), i.e., evitar agir com soberba, preferindo abrandar o poder com benignidade e clemência, e ser justo tanto com seus aliados quanto com seus inimigos; e o que César deve fazer para a afirmação da paz (4.3 - 8.7), i.e., reprimir os apetites da juventude, evitar que a nobreza acumule riquezas senão distintamente, impedir que as províncias e a Itália sejam alvo de sedição e evitar injustiças em relação aos veteranos de guerra.

Na segunda epístola, as provas patéticas relacionam-se ao que César deve fazer para evitar o conflito (5.1 - 12.8), i.e., aumentar o número de cidadãos romanos, promover a concórdia entre jovens e velhos, diminuir a ganância e aumentar a autoridade do senado com a ampliação do número de senadores e com a mudança das regras de eleição.

As provas éticas reúnem todo o exposto acerca da obtenção da fides utilizando-se da imitação, especialmente no que se refere à edificação da auctoritas do orador no discurso. Significa isso dizer que entendo imitação como um procedimento conveniente aos exercícios de formação do orador a fim de aperfeiçoar o estilo. A imitação, portanto, é entendida aqui como procedimento válido não apenas para superar o modelo, mas ainda resgatar o que nele haja de melhor (q.v. Quintiliano Inst. Or. X 2, 10).

A arte do orador é percebida no ato mesmo de discursar, o qual é seguido da imitação e da disciplina no escrever, como o noticiam Cícero (De or. I 32.150-152) e Quintiliano (Inst. Or. X 3 et seq.). Em conjunto, a imitação e a disciplina fornecem ao orador um estoque de ideias, oferecendo as palavras de acordo com a causa. A leitura e a imitação dos antigos define, pois, um espectro de figuras e tropos adequados a cada discurso, além de dispor ao orador quais matérias são adequadas a que situações.

Nesse sentido, Cícero, por exemplo (De or. II 22.90 et seq.), chama a atenção para a necessidade da imitação do que, no modelo, não é fácil nem particular, a fim de o aprendiz discernir o decoroso do indecoroso no seu próprio discurso, cuja elaboração se inicia na escolha cuidadosa dos elementos que se sobressaem no modelo aprovado (cf. Russell in West \& Woodman, 2001 
[1979], p. 5). Isso porque as diversas situações discursivas a que o orador se submete tratando de negócios públicos (De or. II 11.44-48) não aparecem de todo elencadas na preceptiva retórica, mas demandam o mesmo tratamento expressivo (De or. II 12.50).

Ao listar os autores mais importantes para imitação (e assim retomando Cícero, De or. II 12.51 et seq.), o critério de Quintiliano (Inst. Or. X 31 et seq.) é segui-los pelo gênero. Ele lembra que também a história pode trazer a excelência desejada porque, simultaneamente, oferece glória ao talento do orador e retém a memória dos eventos para as futuras gerações, evitando o tédio graças ao uso de palavras arcaicas e de figuras mais livres.

Salústio, pois, deve ser lembrado pela concisão (breuitas), que mantem a atenção de um juiz desatento e mesmo inerudito, constituindo fonte da maior importância para o orador em formação. Por definição, a concisão é produzida isolando as palavras e obtida quando nenhuma delas sirva para falar de maneira obscura (Cíc. Part. or. 19).

Isso indica que a imitação abrange tanto as ações (facta, como o menciona Quintiliano, Inst. Or. IX 2, 58) - o que a aproxima da hipotipose - quanto as palavras (dicta, loc. cit.), configurando o que Quintiliano trata ora como figura, ora como exercício: a etopeia, de que venho tratando (sob o nome dado por Teão) em tantos passos desta tese. As finalidades desse exercício são duas: agradar e captar a benevolência, ao nos tornar insuspeitos perante um juiz porque nos valemos de um estilo simples e espontâneo (loc. cit.). Tal procedimento inclui o fingir pena; o fingir incerteza; o demonstrar ter descoberto algo inteiramente novo; o prover de algo elegante as transições e, por fim, o fingir desconhecimento. Apresento como procede o autor das Ep. ad Caes., fazendo menção às obras de Salústio para conferir autoridade à sua persona.

Primeiramente, a imitação de Salústio pode ser verificada nas passagens:

\section{5.1 satis dictum}

I 5.1 “foi dito o bastante”. 


\section{5.2 ego sic existumo}

I 5.2 “eu assim julgo”.

I 7.4-5 nam saepe ego quom animo meo reputans quibus quisque rebus clari uiri magnitudinem inuenissent quaeque res populos nationesue magnis auctibus auxissent, ac deinde quibus causis amplissima regna et imperia conruissent, eadem semper bona atque mala reperiebam, omnesque uictores diuitias contempsisse et uictos cupiuisse. 5. neque aliter quisquam extollere sese et diuina mortalis adtingere potest, nisi, omissis pecuniae et corporis gaudiis, animo indulgens, non adsentando neque concupita praebendo peruersam gratiam gratificans, sed in labore patientia bonisque praeceptis et factis fortibus exercitando;

I 7.4-5 "Refletindo muitas vezes comigo mesmo sobre aquilo que pôde proporcionar glória aos homens ilustres e aumentar as riquezas de povos ou nações, e depois sobre as causas que destruíram impérios e reinos enormes, percebia que as causas da ventura e da ruína eram sempre as mesmas: todos os vencedores haviam desprezado as riquezas, enquanto os vencidos, haviam-nas desejado. 5. Não há outra maneira de o homem elevar-se e, sendo mortal, poder atingir o divino, a não ser renunciando ao dinheiro e aos prazeres do corpo, entregando-se ao cultivo de sua própria alma, sem assentir ou favorecer à ambição e satisfazer desejos ímprobos, mas ao exercitá-lo nas tarefas difíceis, na paciência, nos bons preceitos, nas belas ações”.

I 8.2 porro ei, quibus bis die uentrem onerare, nullam noctem sine scorto quiescere mos est, ubi animum, quem dominari decebat, seruitio oppressere, nequeicquam eo postea hebeti atque claudo pro exercito uti uolunt. nam imprudentia pleraque et se praecipitat.

I 8.2 “Considero que aqueles que costumam encher o estômago duas vezes ao dia e não passar uma só noite sem a companhia de meretrizes, sendo assim escravos do espírito que 
deveriam dominar, mais tarde, tendo-o enfraquecido e vacilante, debalde quererão exercitálo. 3. Na verdade, é a imprudência que muitas vezes destrói a si mesma”.

II 1.3 Sed mihi studium fuit adulescentulo rem publicam capessere: atque in ea cognoscenda multam, magnamque curam habui: non ita, uti magistratum modo caperem, quem multi malis artibus adepti erant; sed etiam uti rempublicam domi, militiaeque, quantumque armis, uiris, opulentia posset, cognitam haberem.

II 1.3 "Mas desde jovem meu interesse foi zelar pela república, e fiz um grande esforço em conhecê-la não apenas para exercer a magistratura, que muitos alcançaram de maneira ilícita, e sim para que tivesse o conhecimento da república na paz e na guerra, e de quanto podia a opulência de armas e de homens”.

II 10.2 Postquam mihi aetas ingeniumque adoleuit, haud ferme armis, atque equis, corpus exercui, sed animum in litteris agitaui; quod natura firmius erat, id in laboribus habui. 3. Atque ego in ea uita, multa legendo atque audiendo ita comperi, omnia regna, item ciuitates, nationes, usque eo prosperum imperium habuisse, dum apud eos uera consilia ualuerunt: ubicumque gratia, timor, uoluptas, ea corrupere, post paullo imminutae opes, deinde ademtum imperium, postremo seruitus imposita est. 4. Equidem ego sic apud animum meumstatuo: cuicumque in sua ciuitate amplior illustriorque locus, quam aliis est, ei magnam curam esse reipublicae. 5. Nam ceteris, salua urbe, tantummodo libertas tuta est; qui per uirtutem sibi diuitias, decus, honorem pepererunt, ubi paullum inclinata respublica agitari coepit, multipliciter animus curis, atque laboribus fatigatur; aut gloriam, aut libertatem, aut rem familiarem defensat: omnibus locis adest, festinat; quanto in secundis rebus florentior fuit, tanto in aduorsis asperius, magisque anxie agitat.

II 10.2 "Depois que amadureci na idade e no pensamento, não treinei muito o corpo com armas e cavalos, mas exercitei o ânimo nas letras: aquilo que por natureza era mais certo, 
obtive-o pelo esforço. 3. E assim nesta vida eu descobri muitas coisas lendo e ouvindo: todos os reinos - tanto cidades como nações - mantiveram um grande império enquanto lhes valeram os conselhos sinceros: aonde quer que os corrompessem o favor, o medo e a voluptuosidade, vieram as forças diminuídas, depois o império tomado e, por fim, foi-lhes imposta a escravidão. 4. Por isso, na minha opinião, a qualquer pessoa que ocupe um lugar superior e mais ilustre do que outras em sua cidade, cabe-lhe ter cuidado pela república; 5. porque, quando outros mantem a república a salvo, apenas a liberdade é preservada. Aqueles que, por meio da virtude, granjearam riquezas, glória, honra para si, mal começa a república a ser perturbada, multiplicadamente começam a ter o ânimo fatigado por causa das preocupações e dos esforços: ou defendem a glória, ou a liberdade, ou o patrimônio, apressam-se e se apresentam em todos os lugares. Quanto mais florescentes na sorte, tanto mais espinhosos nas adversidades, inquietando-se com mais desassossego”.

II 12.7 Namque mihi pro uero constat, omnium mortalium uitam diuino numine inuisier; neque bonum, neque malum facinus cuiusquam pro nihilo haberi: sed ex natura, diuersa praemia bonos, malosque sequi. 8. Interea forte ea tardius procedunt: suus cuique animus ex conscientia spem praebet.

II 12.7 "Pois me consta que, de fato, a vida de todos os mortais é velada por um nume divino, e a ação boa ou a má de quem quer que seja não fica reservada ao desprezo, e sim bons e maus recebem sua paga da natureza. 8. E se por acaso ela tarda muito, a cada um, neste ínterim, o seu ânimo mostra, por consciência, o que esperar”.

A esses passos, correspondem, em Sal. Bel. Cat., as passagens:

1, 3 Quo mihi rectius videtur ingeni quam virium opibus gloriam quaerere et, quoniam vita ipsa, qua fruimur, brevis est, memoriam nostri quam maxume longam efficere. Nam 
divitiarum et formae gloria fluxa atque fragilis est, virtus clara aeternaque habetur;

1, 3 "Por isso me parece correto buscar a glória mais com as faculdades da alma, que as do corpo; e, como a vida que fruímos é breve, prolongar ao máximo possível a memória de quem fomos. Porquanto a glória da beleza e das riquezas é fugitiva e frágil, a virtude é tida como ilustre e eterna”.

2, 3 Quodsi regum atque imperatorum animi virtus in pace ita ut in bello valeret, aequabilius atque constantius sese res humanae haberent neque aliud alio ferri nequemutari ac misceri omnia cerneres;

2, 3 "Pois que, se a virtude dos reis e dos generais valesse na paz como na guerra, a situação humana seguiria com mais igualdade e constância, e não se veria mudar-se de um tipo de governo para outro, nem mudarem-se e misturarem-se todas as coisas”.

2, 5 Verum ubi pro labore desidia, pro continentia et aequitate lubido atque superbia invasere, fortuna simul cum moribus inmutatur. Ita imperium semper ad optumum quemque a minus bono transfertur.

2, 5 "Mas quando a desídia tomou o lugar do esforço; a cobiça e a soberba, o lugar da moderação e da equidade, a sorte mudou-se no mesmo momento que os costumes. Assim sempre o poder se transfere do menos bom ao melhor”.

2,7-8 Sed multi mortales, dediti ventri atque somno, indocti incultique vitam sicuti peregrinantes transiere; quibus profecto contra naturam corpus voluptati, anima oneri fuit. Eorum ego vitam mortemque iuxta aestumo, quoniam de utraque siletur.

2,7-8 "Mas muitos homens, dados ao ventre e ao sono, viveram indoutos e incultos como peregrinos; à revelia da natureza, seu corpo foi um ídolo e a alma, um peso. Julgo terem tido uma vida e uma morte justas, porque ambas passaram em silêncio”. 
3, 3 Sed ego adulescentulus initio, sicuti plerique, studio ad rem publicam latus sum ibique mihi multa advorsa fuere.

3, 3 “Mas, quando jovem, eu a princípio fui como os outros, levado pela ambição à administração pública e ali muito encontrei contra mim”.

4, 1 Igitur ubi animus ex multis miseriis atque periculis requievit et mihi reliquam aetatem a re publica procul habendam decrevi, non fuit consilium socordia atque desidia bonum otium conterere neque vero agrum colundo aut venando servilibus officiis, intentum aetatem agere; 4, 1 "Portanto livrei-me de muitas desgraças e perigos, e decidi passar o resto da vida longe da administração pública. Minha intenção não foi consumir na indolência e na preguiça um ócio justo, nem me dedicar a ocupações servis, cultivando a terra”.

5, 6 Hunc post dominationem L. Sullae lubido maxuma invaserat rei publicae capiundae; 5, 6 “Depois da tirania de L. Sula, um terrível desejo de dominar invadira a república”.

9, 1-2 Igitur domi militiaeque boni mores colebantur; concordia maxuma, minuma avaritia erat; ius bonumque apud eos non legibus magis quam natura valebat. Iurgia, discordias, simultates cum hostibus exercebant, cives cum civibus de virtute certabant.

9, 1-2 “Assim na paz como na guerra cultivavam-se os bons costumes; a concórdia era máxima e a avareza, mínima; respeitava-se entre eles [i.e., os antigos] a justiça e o bem não mais em função das leis do que da natureza. As rusgas, as discórdias, os rancores destinavam-se aos inimigos: cidadão com cidadão só disputava em virtude”.

11, 1-5 Sed primo magis ambitio quam avaritia animos hominum exercebat, quod tamen vitium propius virtutem erat. Nam gloriam, honorem, imperium bonus et ignavus aeque sibi exoptant; sed ille vera via nititur, huic quia bonae artes desunt, dolis atque fallaciis 
contendit. Avaritia pecuniae studium habet, quam nemo sapiens concupivit: ea quasi venenis malis inbuta corpus animumque virilem effeminat, semper infinita, insatiabilis est, neque copia neque inopia minuitur. Sed postquam L. Sulla armis recepta re publica bonis initiis malos eventus habuit, rapere omnes, omnes trahere, domum alius, alius agros cupere, neque modum neque modestiam victores habere, foeda crudeliaque in civis facinora facere. 11, 1-5 "Mas a princípio mais a ambição do que a avareza atormentava os ânimos humanos, porque o vício, todavia, era a outra face da virtude. O homem de bem e o ignaro desejavam para si as honras, a glória, o império; mas aquele marcha pelo caminho verdadeiro, e esse, como lhe faltam virtudes, emprega o dolo e a intriga. A avareza busca o ouro com empenho, o qual nenhum sábio desejou; como que embebida em veneno mortal, ela efemina o corpo e a alma humana; sempre infinita, é insaciável, e nem com a abundância ou com a privação se mitiga. Mas depois que L. Sula, tomada a república com armas, tirou maus resultados de bons princípios, todos começaram a roubar, todos começaram a querer para si: um cobiçava a casa, outro o campo; e os vencedores perderam o limite e a modéstia, cometendo atos ignominiosos e cruéis contra os concidadãos”.

12, 4-5 Verum illi delubra deorum pietate, domos suas gloria decorabant neque victis quicquam praeter iniuriae licentiam eripiebant.

12, 4-5 “Com efeito, eles decoravam os templos com a devoção, as suas casas com a própria glória; e mesmo aos vencidos não tiravam outra liberdade senão a de fazer o mal”.

13, 2-5 Sed lubido stupri, ganeae ceterique cultus non minor incesserat: viri muliebria pati, mulieres pudicitiam in propatulo habere; vescendi causa terra marique omnia exquirere; dormire prius, quam somni cupido esset; non famem aut sitim, neque frigus neque lassitudinem opperiri, sed ea omnia luxu antecapere. Haec iuventutem, ubi familiares opes defecerant, ad facinora incendebant: animus inbutus malis artibus haud facile lubidinibus 
carebat; eo profusius omnibus modis quaestui atque sumptui deditus erat.

13, 2-5 "O estupro, a gula e todos os outros vícios não grassaram menos: havia homens prostituindo-se como mulheres; mulheres leiloando a castidade; esquadrinhavam-se a terra e o mar; dormia-se antes do sono, não se esperava a fome, a sede ou o cansaço, pois tudo isso era antecipado pelo luxo. Na falta de patrimônio, esses vícios atiçavam a juventude para a criminalidade: envolvidos pelos maus costumes, nunca faltavam vontades àqueles ânimos; por isso, mais profusamente se davam a ganhar e a dispender de todos os modos”.

19, 5 satis dictum.

19, 5 "foi dito o bastante"

51, 15 Equidem ego sic existumo, patres conscripti, omnis cruciatus minores quam facinora illorum esse.

51, 15 “Sem dúvida, pais conscritos, eu, para um crime tal, acho leve todo o tormento”.

e, em Bel. Iug., as passagens:

1, 3-4 Qui ubi ad gloriam virtutis via grassatur, abunde pollens potensque et clarus est neque fortuna eget, quippe quae probitatem, industriam aliasque artis bonas neque dare neque eripere cuiquam potest. Sin captus pravis cupidinibus ad inertiam et voluptates corporis pessum datus est, perniciosa libidine paulisper usus, ubi per socordiam vires tempus ingenium diffluxere, naturae infirmitas accusatur: suam quisque culpam auctores ad negotia transferunt.

1, 3-4 “Quando [a mente] se dirige à glória pelo caminho da virtude - abundantemente vigorosa, potente e ilustre - dispensa a sorte, porque essa não pode dar nem tirar a ninguém a probidade, a industriosidade e as demais características boas. Porém, uma vez cativa dos 
maus desejos, entregou-se à inércia e aos prazeres do corpo; se a tais perniciosos vícios acostumou-se ao menos um pouco, depois de ter, devido à indolência, perdido as forças, o tempo e a razão, acusa-se a debilidade da natureza: aqueles que agem de má fé transferem sua culpa às circunstâncias”.

2, 1-4 Nam uti genus hominum compositum ex corpore et anima est, ita res cuncta studiaque omnia nostra corporis alia, alia animi naturam secuntur. Igitur praeclara facies, magnae divitiae, ad hoc vis corporis et alia omnia huiusce modi brevi dilabuntur; at ingeni egregia facinora sicuti anima immortalia sunt. Postremo corporis et fortunae bonorum ut initium sic finis est, omniaque orta occidunt et aucta senescunt: animus incorruptus, aeternus, rector humani generis agit atque habet cuncta neque ipse habetur. Quo magis pravitas eorum admiranda est, qui, dediti corporis gaudiis, per luxum et ignaviam aetatem agunt, ceterum ingenium, quo neque melius neque amplius aliud in natura mortalium est, incultu atque socordia torpescere sinunt, cum praesertim tam multae variaeque sint artes animi, quibus summa claritudo paratur.

2, 1-4 "Sendo, pois, o ser humano composto de corpo e alma, todas as suas razões e vontades seguem a natura dessa ou daquele; Assim a beleza, as grandes riquezas, o vigor do corpo e tudo o mais em breve se dissipam; no entanto, as sublimes realizações do engenho humano são, como a alma, imortais. Por fim, os bens do corpo e da alma, como têm princípio, têm fim, e tudo aquilo que nasce, morre; as coisas que cresceram, envelhecem. Um ânimo incorrupto, eterno, senhor do homem, move e possui tudo, sem ser possuído. Mas é de se admirar, por isso, a depravação daqueles que, dados aos prazeres do corpo, consomem a vida no luxo e na moleza, deixando entorpecer o engenho - que é o melhor e mais sublime dom da natureza - no descuido e na indolência enquanto existem tantos e tão diferentes expedientes com os quais obter fama e glória”. 
19, 8 satis dictum.

19, 8 “foi dito o bastante”

Desse achado, existem coincidências na elocução e na invenção entre Ep. ad Caes. II 1.3-4 e Bel. Cat. 3,3 ${ }^{128}$; entre Ep. ad Caes. II 10.2 e Bel. Cat. 4,1 $1^{129}$; entre Ep. ad Caes. I 8.2 e Bel. Cat. 2,7-8 ${ }^{130}$; entre Ep. ad Caes. I 4.1, Ep. ad Caes. II 4.1 e Bel. Cat. 5,6 $6^{131}$; entre Ep. ad Caes. II 5.3-5 e Bel. Cat. 9, 1-2, Bel. Cat. 11,1-5 e Bel. Cat. 12,4-5 ${ }^{132}$; entre Ep. ad Caes. I 7.4 e Bel. Cat. 13, $2^{133}$; entre Ep. ad Caes. I 5,2 e Bel. Cat. 51,15 ${ }^{134}$ e, por fim, entre Ep. ad Caes. I 5.1, Bel. Cat. 19,5 e Bel. Iug. 18,8135 .

Tais coincidências devem-se, em parte, à imitação daquilo que Salústio utiliza para justificar sua autoridade no aconselhar e, em parte, à imitação daquilo que em Salústio poder-se-ia chamar estilo. Significa isso dizer que as diversas passagens supracitadas, a par de outras tantas levantadas

128 Grifo meu Ep. ad Caes. II 1.3-4 Sed mihi studium fuit adulescentulo rem publicam capessere: atque in ea cognoscenda multam magnamque curam habui; Bel. Cat. 3,3 Sed ego adulescentulus initio, sicuti plerique, studio ad rem publicam latus sum.

129 Grifo meu Ep. ad Caes. II 10.2 Postquam mihi aetas ingeniumque adoleuit, haud ferme armis, atque equis, corpus exercui, sed animum in litteris agitaui; quod natura firmius erat, id in laboribus habui; Bel. Cat. 4,1 Igitur ubi animus ex multis miseriis atque periculis requievit et mihi reliquam aetatem a re publica procul habendam decrevi, non fuit consilium socordia atque desidia bonum otium conterere neque vero agrum colundo aut venando servilibus officiis, intentum aetatem agere.

130 Grifo meu Ep. ad Caes. I 8.2 porro ei, quibus bis die uentrem onerare, nullam noctem sine scorto quiescere mos est, ubi animum, quem dominari decebat, seruitio oppressere; Bel. Cat. 2,7-8 Sed multi mortales, dediti uentri atque somno, indocti incultique uitam sicuti peregrinantes transiere; quibus profecto contra naturam corpus uoluptati, anima oneri fuit.

131 Grifo meu Ep. ad Caes. I 4.1 An illa, quae paulo ante hoc bellum in Cn. Pompeium uictoriamque Sullanam increpabantur; Ep. ad Caes. II 4.1 L. Sulla, cui omnia in uictoria lege belli licuerunt, tametsi supplicio hostium partes suas muniri intellegebat e Bel. Cat. 5,6 Hunc post dominationem L. Sullae lubido maxuma inuaserat rei publicae capiundae.

132 Grifo meu Ep. ad Caes. II 5.3-5 Sed plebs eo libere agitabat quia nullius potentia super leges erat, neque diuitiis aut superbia sed bona fama factisque fortibus nobilis ignobilem anteibat: humillumus quisque in aruis aut in militia nullius honestae rei egens satis sibi satisque patriae erat; Bel. Cat. 9, 1-2 Igitur domi militiaeque boni mores colebantur; concordia maxuma, minuma avaritia erat; ius bonumque apud eos non legibus magis quam natura valebat. Iurgia, discordias, simultates cum hostibus exercebant, cives cum civibus de virtute certabant; Bel. Cat. 11,1-5 Sed primo magis ambitio quam avaritia animos hominum exercebat, quod tamen vitium propius virtutem erat; Bel. Cat. 12,4-5 Verum illi delubra deorum pietate, domos suas gloria decorabant neque victis quicquam praeter iniuriae licentiam eripiebant. At hi contra, ignavissumi homines, per summum scelus omnia ea sociis adimere, quae fortissumi viri victores reliquerant: proinde quasi iniuriam facere id demum esset imperio uti.

133Grifo meu Ep. ad Caes. I 7.4 nam saepe ego quom animo meo reputans quibus quisque rebus clari uiri magnitudinem inuenissent quaeque res populos nationesue magnis auctibus auxissent, ac deinde quibus causis amplissima regna et imperia conruissent, eadem semper bona atque mala reperiebam, omnesque uictores diuitias contempsisse et uictos cupiuisse; Bel. Cat. 13, 2 Quibus mihi uidentur ludibrio fuisse diuitiae: quippe, quas honeste habere licebat, abuti per turpitudinem properabant.

134Ep. ad Caes. I 5.2 ego sic existumo; Bel. Cat. 51,15 ego sic existumo.

135Ep. ad Caes. I 5.1 satis dictum; Bel. Cat. 19,5 satis dictum e Bel. Iug. 18,8 satis dictum. 
pelos filólogos $^{136}$, recuperam as virtudes da obra supérstite do referido historiador, mormente a Conjuração de Catilina, de que as duas Ep. ad Caes. se valem sobretudo imitando o exórdio e a narração. Importante dizer, aqui, que as passagens cotejadas apresentam identidade ora quanto à invenção, ora quanto à elocução, mas não quanto à disposição porque, se aqueles dois primeiros elementos se conjugam, esse terceiro não apresenta identidade nem quando a imitação ocorre relacionando as partes da Conjuração de Catilina ou da Guerra Jugurtina com as partes das Ep. ad Caes., nem quando a imitação ocorre relacionando as duas Ep. ad Caes.

A identidade existente entre as Ep. ad Caes. II 1.3-4 = Bel. Cat. 3,3 e 4,1; Ep. ad Caes. I 8.2 = Bel. Cat. 2,7-9; Ep. ad Caes. I 4.1 e II 4.1 = Bel. Cat. 5,6; Ep. ad Caes. II 5.3-5 = Bel. Cat. 9, 1-2, 11,1-5, 12,4-5; Ep. ad Caes. I 6.4 e 7,4-5 = Bel. Cat. 13, 2-5 e 14,7 e Ep. ad Caes. I 3.2-4 = Bel. Cat. 15,1 quanto à autoridade no aconselhamento ocorre quando há a menção ao empenho dedicado ao conhecimento da política acumulado desde a juventude; à contenção dos afetos e apetites para demonstrar a virtude honesta que o homem político deve demonstrar no serviço à república, a partir dos exemplos opostos, i.e., os amantes do prazer e do luxo; à identificação de Sula como o responsável pelo ingresso dos excessos e arbitrariedades que, mais tarde, geraram o conflito civil; à prisca austeridade dos romanos, que regulava e justificava as benesses romanas e, por fim, à explicação do poder do dinheiro e da corrupção da juventude no desencadeamento de conflitos civis. Há, pois, nas duas Ep. ad Caes. o estabelecimento de princípios gerais que depõem sobre a persona responsável pelo aconselhamento - e sobre sua autoridade para aconselhar - cumprindo os requisitos do discurso deliberativo, a saber, a utilitas e a honestas (cf. Cícero, De or. II 81.333$334)^{137}$

Digo que existem princípios gerais para a construção da persona responsável pelo

136Duas das três edições das Ep. ad Caes. por mim consultadas, seja a de A. Ernout. (1962), seja a de Virgilio Paladini (1968), comparecem como notas de rodapé as passagens retiradas ou muito semelhantes aos textos supérstites de Salústio. Não as reproduzo integralmente aqui em respeito à proposta de uma tese. Mais adiante, retomo algumas dessas passagens para análise da elocução nas Ep. ad Caes.

137Diz Cícero (De or. II 82.335) que, havendo acordo sobre a necessidade de uma ação, é necessário decidir pela honestas ou pela utilitas. Assim, quem defende a utilitas deve enumerar as vantagens da paz, dos recursos, do poder, dos tributos, da proteção com soldados e das demais coisas cujos frutos medimos pela utilidade. Tais são os argumentos das Ep. ad Caes. 
aconselhamento porque nas duas Ep. ad Caes. apresentam-se os aspectos para tal construção baseados:

a) no empenho que o orador destinou ao acúmulo de conhecimento sobre o governo, o que o autoriza falar a César prudentemente sobre a gerência da república;

b) na explicitação da causa para a decadência dos costumes, a saber, a corrupção da juventude e a entrega dos homens de má índole a seus apetites;

c) no amparo filosófico para justificar as mudanças que Roma sofreu com passar dos séculos (especialmente Ep. ad Caes. II 5, 3-5; Ep. ad Caes. II 5, 3-5 = Bel. Cat. 9, 1-2, 11, 1-5, 12, 4-5), como as repúblicas mudam dependendo do caráter de quem as governa (Ep. ad Caes. I 3.1 et seq.) e de como o homem deve cultivar seu ânimo com as belas ações (Ep. ad Caes. I 7.5).

Quanto à imitação daquilo que em Salústio poder-se-ia chamar estilo, apresento as identificações entre Ep. ad Caes. II 1, 3; II 2, 4; II 12, 5 (domi militiaeque) = Bel. Cat. 5, 9; 6, 5; 29, 3; 53, 2; Bel. Iug. 14, 1; 31, 25 e Ep. ad Caes. I 5, 1 (satis dictum) = Bel. Cat. 19, 5; e Bel. Iug. 18, 8, duas das dezenas de similaridades e coincidências relatadas por todos os filólogos que estabeleceram o texto integral dos dois discursos nas edições francesa e italiana (cf. n. 32). Tal identificação é de natureza elocutiva, uma vez que há palavras, expressões ou orações reproduzidas conforme apareçam nas obras de Salústio.

De todo o arrazoado, reforço que a imitação nas Ep. ad Caes. recai tanto sobre a elocução da obra supérstite de Salústio, quanto sobre a persona construída no e pelo discurso desse historiador - e daí a identificação delas com o exórdio de Bel. Cat. e Bel. Iug. - cuja matéria, utilizando-se dos tópicos da razão honesta sobre a segura, preenche os quatro aspectos para a construção de tal persona - paixões, hábitos, idade e fortuna (cf. Ar. Rhet. 1388B).

O caráter digressivo da peroração não é regularmente obedecido nas duas Ep. ad Caes., 
porque nelas a peroração filia-se ao gênero demonstrativo. Digo, pois, que a peroração depõe sobre as afecções, affectus (cf. Quint. Inst. Or. VI 1,1), mas o faz de maneiras distintas para atingir o mesmo objetivo, i.e., dispor no destinatário o favor à causa.

Compõe-se como peroração da primeira Ep. ad Caes. a seção 8, 7-10, em que o autor promove o aconselhamento usando da sua própria pessoa e deseja ao destinatário sorte para a realização do que seja o mais correto a fazer. Sendo assim, o orador vale-se da conquestio (Quint. Inst. Or. VI 27-28), i.e., a conquista da simpatia em sua própria causa, que por essa mesma razão não torna a peroração nem longa nem excessivamente patética, para não fatigar o destinatário e fazer regredir sua disposição em aceitar a causa.

Compõe-se como peroração da segunda Ep. ad Caes. a seção 13, 1-8, em que o autor lembra a grandeza de César para a realização das ações que pleiteia. Nela, a conquestio utiliza expedientes distintos daqueles utilizados no discurso anterior, a saber, a amplificação, amplificatio, e a personificação, prosopopeia, figura aliás valorizada nessa parte do discurso (Quint. Inst. Or. VI 1, 25). Ao lembrar o que a pátria e os pais diriam a César quando da reconstrução da república, o autor reforça o caráter grandioso de seus feitos lembrando o poder da fortuna $(13,7)$ sobre o devir dos homens, outro dos loci communes com os quais se conquista a simpatia do destinatário (cf. Cíc. De inv. $1,55,106)$.

De um lado, enquanto uma controvérsia completa consistia de proêmio, narração e epílogo, de outro a suasória não requeria a narração, sendo composta apenas de um principium e de várias quaestiones encerradas por algum tipo de epílogo, que não era obrigatório (Fairwhether, 1981, p. 179 citando Sen. Contr. I.1.24f.; I.1.21; I.6.9.; II.2.12; IV pr.8; VII.7.19; Suas. 7.14.). Tanto a presença da narração quanto da peroração nas Ep. ad Caes., portanto, não compartilham da disposição das suasoriae tal como registradas por Sêneca, o Velho. A narração, contudo, entre as partes do discurso, é a que mais contribui para a definição das Ep. ad Caes. como exercício tanto pelo seu papel na argumentação quanto pela sua prescrição entre os demais praeexercitamina, os quais se combinavam em discursos maiores. No caso dos dois documentos analisados nesta tese, a 
narração traz os historica exempla que ornamentam os loci moralizantes da confirmação (cf. Fairwhether, 1981, p. 183), daí a sua contraditória importância. A narração contribui para a divisão de cada um dos documentos em dois grandes grupos de tópicos, conforme se verá a seguir.

\section{De parte artis: arranjo dos tópicos}

Esta seção apresenta, com base no que foi exposto acima, a disposição dos tópicos nas duas Ep. ad Caes. segundo a preceptiva de Cícero (Top. ii.6), para quem os tópicos são inerentes à matéria do discurso.

Ambos os documentos apresentam uma estrutura semelhante (Chouet, 1950, pp. 70-72), cujo exórdio e narração reforçam as virtudes do destinatário em oposição ao seu adversário (quer seja ele Pompeu, quer sejam os membros da nobreza), seguidos de uma argumentação bipartite sobre o controle da situação e sobre as virtudes necessárias para que isso ocorra; por fim, na peroração, a persona do orador obsecra o favor divino às ações de César.

Dessas partes, a primeira (exórdio e narração) serve para introduzir o estado da questão (an faciendum/an fieri possit), uma vez que a questão é definida, simples e de qualidade. Na primeira epístola, César está habilitado para salvar e preparar a república para o futuro através das vantagens da paz (I 1.8). Seus inimigos o injuriaram, não usaram de raciocínio próprio ao se lançarem à guerra e se deixaram levar ou por questões de parentesco, ou por corrupção de caráter ou por terem feito dívidas, e por tais razões serviram-se do apoio a Pompeu, homem ambicioso e mais dotado de sorte, que de razão (I 2.1-7).

Na segunda epístola, César deve agir, quanto aos assuntos urbanos em meio à guerra (II 2.3; 4.4), porque Cneu Pompeu desconcertou a república, entregando a uns poucos senadores o sumo poder de administrar os impostos, os gastos públicos e as decisões judiciais. Estes fazem e desfazem o que querem, perseguem inocentes, favorecem apenas amigos e familiares, praticam toda sorte de crimes para obter cargos e desprezam as leis (II 3.1-5; 4.2). Além disso, Pompeu aprovou outras leis 
que sufocaram a plebe (II 4.2).

Muito embora o tópico presente nessas partes pertença, originalmente, à questão indefinida (thésis ou propositum; quaestio infinita), pode ele também integrar uma questão definida (hypóthesis ou causa) (Cíc. Top. xxi, 79-80). Como percebido, no exórdio e na narração os dois discursos seguem o tópico da comparação, ex comparatione, o mais adequado para as questões teoréticas ou de conhecimento.

A preceptiva retórica estabelece (Cíc. Top. xxii, 84 - xxiv. 91), para as questões de qualidade, a distinção entre o justo e o injusto; essa distinção, quanto à complexidade, pode dividir a questão em simples (simpliciter; simplex) ou dupla (comparate; comparata), cujas finalidades apontam o gênero da causa (deliberativo, demonstrativo e judiciário). Possuindo uma questão simples e pertencendo as Ep. ad Caes. ao gênero deliberativo, mas combinadas, no exórdio, a elementos do demonstrativo, a distinção entre o justo e o injusto tanto se apóia nas finalidades do gênero deliberativo - expetendo fugiendoque - quanto do gênero demonstrativo - honesto et turpi.

O exórdio de ambos os discursos já apresenta a distinção entre o justo e o injusto visando enobrecer a matéria, valendo-se apenas dos tópicos da causa honesta. Isso ocorre nas passagens:

a) Para a justiça:

I 1.7-8 Sed tibi hoc grauius est quam ante te omnibus, armis parta componere. Bellum aliorum pace mollius gessisti: ad hoc uictores pradam petunt, uicti ciues sunt.

I 1.7-8 "Mas para ti o que é mais difícil do que para todos os teus antecessores é isto: organizar o que obtiveste com armas. Foste mais direito na guerra do que outros, na paz. Para isso os vencedores buscam a presa; os vencidos são cidadãos”.

II 2.4 Sin in te ille animus est, qui iam a principio nobilitatis factionem disturbauit, plebem romanam ex graui seruitute in libertatem restituit, in praetura inimicorum arma inermis disiecit, domi militiaeque tanta et tam praeclara facinora fecit, uti ne inimici quidem queri 
quidquam audeant, nisi de magnitudine tua; quin accipe tu ea, quae dicam de summa republica, quae profecto aut tu uera inuenies, aut certe haud procul a uero.

II 2.4 “Porém, se há em ti aquela disposição, que desde o princípio já dispersou a facção da nobreza, restituiu de uma cruel servidão a liberdade à plebe romana, derrotou, inerme, as armas dos inimigos durante a pretura e promoveu tantas e tão importantes ações na paz e na guerra que nem mesmo os inimigos ousariam queixar-se senão de tua grandeza, aceita então aquilo que direi sobre o bem comum, que acharás verdadeiro ou decerto não distante da verdade”.

b) Para a coragem:

I 1.8-9 inter has difficultates euadendum est tibi atque in posterum firmanda res publica non armis modo neque aduorsum hostis, sed, quod multo multoque asperius est, pacis bonis artibus.

I 1.8-9 “Em meio a tais dificuldades deves também salvar e preparar a república para o futuro, não só com o apoio das armas ou com assaltos aos inimigos e sim - o que é muito e muito mais difícil - com as vantagens da paz”.

II 1.5 Idque non temere, aut fortuna tua decreui, sed quia in te, praeter ceteras, artem unam egregie mirabilem comperi, semper tibi maiorem in aduorsis, quam in secundis rebus animum esse.

II 1.5 "Não decidi isso temerariamente ou em consequência de tua fortuna, mas porque averiguei em ti, particularmente, uma só admirável arte, além de outras: tua coragem é sempre maior na adversidade do que na sorte”.

c) Para a modéstia:

I 1.6 At contra id eniti decet, cum ipse bonus atque strenuus sis, uti quam optimis imperites, 
nam pessumus quisque asperrume rectorem patitur.

I 1.6 “Convém te esforçares no sentido oposto, sendo, tu mesmo, bom e diligente, para que governes os melhores, pois os piores homens suportam penosamente um chefe”.

II 1.4 Itaque mihi multa cum animo agitanti consilium fuit, famam, modestiamque meam post tuam dignitatem habere, et cuius rei lubet periculum facere, dum quid tibi ex eo gloria accederit.

II 1.4 “Assim, depois de pensar muito, tomei a decisão de colocar minha fama e minha modéstia atrás de tua dignidade, e de correr todo o tipo de perigo, desde que disso resulte a tua glória”.

Os defeitos do adversário - apresentados na narração - amplificam as partes da causa honesta, o que pode ser verificado nas passagens:

a) Para a inépcia:

I 2.2 Bellum tibi fuit, imperator, cum homine claro, magnis opibus, auido potentiae, maiore fortuna, quam sapientia. Quem secuti sunt pauci, per suam iniuriam tibi inimici; item quos adfinitas, aut alia necessitudo, traxit.

I 2.2 "Estiveste em conflito, imperador, contra um homem ilustre, de grande autoridade, ávido pelo poder, dotado de maior sorte do que esperteza, a quem seguiram uns poucos que se declararam inimigos teus por injúria, bem como aqueles a quem arrastou o parentesco ou alguma outra necessidade”.

II 3.1. Sed quoniam Cn. Pompeius, aut animi pravitate, aut quia nihil eo maluit, quam quod tibi obesset, ita lapsus est ut hostibus tela in manus iaceret.

II 3.1 “Uma vez que Cn. Pompeu, no entanto, ou por desatino ou por preferir algo que te 
obstruísse, assim se enganou, entregando as armas às mãos dos inimigos”.

b) Para a covardia, fraqueza e liberalidade torpe:

I 2.5-6 Per idem tempus maledictis iniquorum occupandae reipublicae in spem adducti homines, quibus omnia probro ac luxuria polluta erant, concurrere in castra tua; et aperte quietis mortem, rapinas, postremo omnia, quae corruptus animus lubebat, minitari. Ex quis magna pars, ubi neque creditum condonarei, neque te ciuibus, sicuti hostibus, uti uident, defluxere; pauci restitere, quibus maius otium in castris, quam Romae, futurum erat; tanta uis creditorum impendebat.

I 2.5-6 “Ao mesmo tempo, homens manchados por toda a luxúria e torpeza avançaram contra teus acampamentos, levados pelas calúnias de infames na esperança de tomar o poder, e ameaçavam abertamente os inocentes com a morte, roubo e tudo enfim que agrade a um espírito corrompido. Grande parte desses, percebendo que tu não perdoavas as dívidas nem vias concidadãos como inimigos, desistiu; poucos preferiram resistir nos acampamentos a permanecer em Roma, tamanha era a soma que deviam aos credores”.

II 3.2-4 Primum omnium, summam potestatem moderandi, de uectigalibus, sumtibus, iudiciis, senatoribus paucis tradidit; plebem romanam, cuius antea summa potestas erat, ne aequis quidem legibus, in seruitute reliquit. Iudicia tametsi, sicut antea, tribus ordinibus tradita sunt; tamen iidem illi factiosi regunt, dant, adimunt, quae lubet: innocentes circumueniunt; suos ad honorem extollunt; non facinus, non probrum aut flagitium obstat, quo minus magistratus capiant: quod commodum est, trahunt, rapiunt: postremo, tanquam urbe capta, lubidine ac licentia sua, pro legibus utuntur.

II 3.2-4 “Antes de tudo, ele restituiu a uns poucos senadores o sumo poder de administrar os impostos, os gastos públicos e as decisões judiciais, e por meio de leis iníquas lançou sem demora a plebe romana, que outrora possuía o máximo poder, à escravidão. 3. Mesmo 
entregues, como antigamente, às três ordens, rege a mesma facção aos assuntos judiciais, fazendo e desfazendo o que quer, perseguindo inocentes, elevando os seus às honras. 4. Não se impede um crime, uma infâmia, uma torpeza sem que eles tomem um cargo, o qual, se for vantajoso, roubam ou põem a perder. Por fim, como numa cidade capturada, eles se valem, no lugar das leis, de sua ganância e licenciosidade”

c) Para a temeridade:

I 2.4. Cetera multitudo uolgi, more magis quam iudicio, post alius alium, quasi prudentiorem, secuti.

I 2.4 “Outro número de pessoas, mais por hábitos do vulgo do que por bom senso, seguiram uns aos outros como quem segue o mais prudente”.

II 3.6-7 Ac me quidem mediocris dolor angeret, si uirtute partam uictoriam, more suo, per seruitium exerceret; sed homines inertissumi, quorum omnis uis, uirtusque in lingua sita est, forte, atque alterius socordia dominationem oblatam insolentes agitant. Nam, quae seditio, ac dissensio ciuilis tot tamque illustres familias ab stirpe auertit? Aut quorum unquam uictoria animus tam praeceps tamque immoderatus fuit?

II 3.6-7 “Mas eu de fato não me admiraria se eles, como de costume, transformassem em escravidão uma vitória alcançada com virtude. 6. Porém os homens mais covardes, dos quais toda a força e virtude estão situadas na língua, promovem, insolentes, uma dominação imposta pela ventura e fraqueza de outrem. 7. Afinal, que sedição e dissensão civil extinguiu tantas e tão ilustres famílias? Ou de quem o ânimo foi, mesmo na vitória, tão precipitado e tão imoderado?”

d) Para a inércia e negligência:

I 2.7. Sed ob easdem causas immane dictu est, quanti et quam multi mortales, postea ad 
Pompeium discesserint: eoque, per omne tempus belli, quasi sacro atque inspoliato fano debitores usi.

I 2.7 "Por essas mesmas razões, é espantoso dizer quais e quantos mortais passaram para o lado de Pompeu e como se serviram dele, durante toda a guerra, como de um templo sagrado e inviolável”.

II 4.2 At hercule nunc a M. Catone, L. Domitio, ceterisque eiusdem factionis, quadraginta senatores, multi praeterea cum spe bona adolescentes, sicuti hostiae, mactati sunt, quom interea importunissuma genera hominum tot miserorum ciuium sanguine satiari nequiere: non orbi liberi, non parentes exacta aetate, non gemitus uirorum, luctus mulierum, immanem eorum animum inflexit, qui, acerbius in dies male faciundo ac dicundo, dignitate alios, alios ciuitate euersum irent.

II 4.2 "Mas, por Hércules, a comando de M. Catão, L. Domício e de outros da mesma facção, foram oferecidos como vítimas quarenta senadores, muitos, aliás, jovens promissores, enquanto a espécie mais perigosa de homens não pode se saciar do sangue de tantos míseros civis: nem os órfãos, nem os pais de idade avançada, nem a dor e o lamento de homens e mulheres venceu-lhes o ânimo cruel. Ademais, dizendo e fazendo o mal com crescente crueldade, quiseram privar uns de sua dignidade, outros dos direitos de cidadãos”.

O exórdio e a narração tanto devem mover o ânimo quanto estabelecer a credibilidade do discurso, preparando a audiência para a argumentação. Nas Ep. ad Caes., tais são os objetivos dos tópicos da causa honesta. Entretanto, como mencionado anteriormente, o enobrecimento da matéria exige, ainda, a menção às partes da causa segura (Rhet. ad Her. III. 3 et seq.), diretamente dependentes das partes da causa honesta.

A argumentação inteira das Ep. ad Caes., portanto, dirige-se ao que César deve fazer para evitar os perigos atuais ou iminentes, quer acabando com a guerra e evitando os novos perigos (I 3. 
2 - 8. 6), quer promovendo as reformas necessárias (II 5.1 - 12.4) para a prosperidade da república. Isso significa que, para debelar a guerra ou restabelecer a paz, César deve aplicar suas virtudes em ações de maior alcance, em que dista de seu adversário pela sua superioridade moral.

O tópico ex comparatione, utilizado no exórdio e na narração das Ep. ad Caes., aparece relacionado ao tópico das causas (locus causarum) (Cíc. Top. xv, 58 - xviii, 67) na confirmação; aquele estabelece as virtudes para César agir, e estes tratam das ações dependentes dessas virtudes.

Tanto o tópico da causa quanto o do efeito são excelentes para filósofos e oradores (Cíc. ibid.), não apenas porque oferecem uma admirável riqueza de expressão (mirabilem copiam dicendi), mas ainda proporcionam ao orador e ao filósofo a possibilidade de argumentar ornada e copiosamente (ornate et copiose loqui possunt), dado o fato de que o conhecimento das causas promove o conhecimento dos efeitos (causarum enim cognitio cognitionem eventorum facit).

Cícero (Cíc. Top. xv, 58 - xvi. 63) divide as causas, ou forças eficientes, pelos gêneros (a de força própria, ui sua, e a que não possui força própria, naturam efficiendi non habet), pela atuação (a que pode produzir efeito, quod efficitur ab ea causa, e a que pode não produzir efeito, in ea non sit efficiendi necessitas), pela voluntariedade (a que não é desejada pela mente, sine ulla appetitione animi, e a que é desejada pela mente, aut uoluntate efficiunt aut perturbatione animi) e pela uniformidade de operação (a que é constante, inest constantia, e a que não é constante, non inest [constantia]).

Dessa divisão, comparece nas Ep. ad Caes. a causa desejada pela mente porque, conforme Cícero (Cíc. Top. xvi, 62), esse tipo de causa é dependente do desejo, da agitação, da disposição, da natureza, da arte ou do imprevisto (aut voluntate efficiunt aut perturbatione animi aut habitu aut natura aut arte aut casu). Relaciona-se, pois, com os tópicos da causa honesta acima mencionados, e está presente nas seguintes passagens:

a) da Ep. ad Caes. I

I 5.3 Firmanda igitur sunt [uel] concordiae bona et discordiae mala expellenda. 4. Id ita 
eueniet, si sumptuum et rapinarum licentiam dempseris, non ad uetera instituta reuocans quae iam pridem corruptis moribus ludibrio sunt, sed si suam quoique rem familiarem finem sumptuum statueris.

I 5.3 “Devem pois serem firmadas, acima de tudo, as vantagens da concórdia e repudiados os males da discórdia. 4. Isto ocorrerá se reprimires a o excesso de luxo e de roubo, não reclamando as antigas instituições (que são, há muito tempo, por causa da corrupção dos costumes, alvo de escárnio), mas determinando a cada um o limite de despesas de acordo com seu patrimônio familiar”.

I 5.7. Quare tollendus fenerator in posterum, uti suas quisque res curemus. 8. Ea uera atque simplex uia est: magistratum populo, non creditori gerere et magnitudinem animi in addendo, non demendo rei publicae ostendere.

I 5.7 "Portanto, no futuro, deve-se exterminar a usura de maneira que cada um de nós cuide de nossos próprios interesses. 8. Eis a maneira mais simples e mais verdadeira para chegar a isto: que o magistrado sirva ao povo, não aos credores, e ostente a sua grandeza de espírito fazendo com que a república ganhe, não perca”.

I 6.2 Postremo sapientes pacis causa bellum gerunt, laborem spe otii sustentant: nisi illam firmam efficis, uinci an uicisse quid retulit? 3. Quare capesse, per deos, rem publicam et omnia aspera, uti soles, peruade: namque aut tu mederi potes aut omittenda est cura omnibus. 4. Neque quisquam te ad crudeles poenas aut acerba iudicia inuocat, quibus ciuitas uastatur magis quam corrigitur, sed ut prauas artis malasque libidines, ab inuentute prohibeas.

I 6.2 "Por último, os sábios travam guerras em benefício da paz, suportam o cansaço na esperança do repouso. Se não fizeres da paz algo duradouro, de que te servirá vencer ou ser vencido? 3. Portanto ocupa-te - pelos deuses! - da república e, como é de teu costume, 
enfrenta até o fim todas as dificuldades, já que somente tu podes remediá-la, ou ninguém mais se atreverá a isso.. 4. Não há ninguém que te peça seres cruel nos castigos ou rígido nos julgamentos, maneiras pelas quais a cidade não é reformada, mas destruída. Deves afastar da juventude as más condutas e os desejos perversos”.

I 7.1 Ac mihi animus, quibus rebus alii timent, maxume fretus est: negotii magnitudine et quia tibi terrae et maria simul omnia componenda sunt. Quippe res paruas tantum ingenium attingere nequeiret, magnae curae magna merces est. 2. Igitur prouideas oportet, uti pleps, largitionibus et publico frumento corrupta habeat negotia sua, quibus ab malo publico detineatur: iuuentus probitati et industriae, non sumptibus neque diuitiis studeat. 3. Id ita eueniet, si pecuniae, quae maxuma omnium pernicies est, usum atque decus dempseris.

I 7.1 “No que me diz respeito, meu espírito se apóia principalmente naquilo que outros temem: na grandeza da obra pela qual terras e mares serão por ti conquistados. Embora tamanha sagacidade não queira chegar a resultados modestos, grandes prêmios provêm de grandes cuidados. 2. Deves, portanto, tomar providências para que a plebe, corrompida pelas liberalidades e pela distribuição de alimento, faça seus negócios sem contribuir para a calamidade pública, e para que a juventude empregue seu vigor na integridade e naquilo que merece esforço, e não no dispêndio e nas dívidas. 3. Isto poderá acontecer se impedires o uso e o respeito ao dinheiro, que é a maior causa da desgraça dos homens”.

I 8.3 Verum haec et omnia mala pariter cum honore pecuniae desinent, si neque magistratibus neque alia uulgo cupienda uenalia erunt. 4. Ad hoc prouidendum est tibi, quonam modo Italia atque prouinciae tutiores sint: id quod factu haut obscurum est. 5. Nam idem omnia uastant, suas deserendo domos, et per iniuriam alienas occupando. 6. Item ne, uti adhuc, militia iniusta aut inaequalis sit, cum alii triginta, pars nullum stipendium faciunt. Et frumentum id, quod antea praemium ignauiae fuit, per municipia et colonias illis 
dare conueniet, qui stipendiis emeritis domos reuerterint.

I 8.3 “Na verdade, é a imprudência que muitas vezes destrói a si mesma. Esse e todos os outros males, assim como a honra concedida ao dinheiro, acabariam se nem a magistratura nem outras coisas desejadas pelo vulgo fossem colocadas à venda. 4. Deves fazer com que a Itália e as províncias fiquem, de alguma maneira, livres de perturbações. E isto não é difícil de ser feito. 5. De fato, são sempre os mesmos que causam desgraças ao abandonar suas casas e ocupar outras ilicitamente. 6. Da mesma forma, deves fazer com que o serviço militar não seja injusto ou desigual, como tem sido até agora, quando alguns têm trinta anos de serviço prestado, enquanto outros sequer chegam a servir. O frumento, que foi dado outrora como um prêmio aos ignavos, convêm distribui-lo pelos municípios e colônias àqueles que retornarem a seus lares tendo cumprido o tempo de serviço militar”.

b) da Ep. ad Caes. II

II 5.6 Haec igitur multitudo primum malis moribus inbuta, deinde in artis, uitasque uarias dispalata, nullo modo inter se congruens, parum mihi quidem idonea uidetur ad capessendam rem publicam. 7. Ceterum additis nouis ciuibus magna me spes tenet fore ut omnes expergiscantur ad libertatem; quippe quum illis libertatis retinendae, tum his seruitutis amittendae cura orietur. 8. Hos ego censeo permixtos cum ueteribus nouos in coloniis constituas: ita et res militaris opulentior erit et plebs bonis negotiis impedita malum publicum facere desinet.

II 5.6 “Por consequência essa multidão, primeiramente imbuída de maus hábitos e depois lançada a diferentes formas de atividade e de vida, de modo algum de acordo consigo, parece-me decerto pouco idônea para administrar a república. 7. Ademais, acrescidos de novos cidadãos, toma-me uma grande esperança de haverem outros que despertem para a liberdade, visto que o apreço tanto nasce, aos patrícios, da liberdade mantida, quanto, à plebe, da servidão perdida. 8. Eu creio que deves estabelecer os novos misturados aos mais 
velhos nas colônias; assim também a força militar será mais poderosa e a plebe, ocupada com assuntos virtuosos, deixará de promover o mal coletivo”.

II 6.4. Sed homines factiosi, quibus dolus atque malitia fide cariora erant, ubi intellexerunt per unum hominem maxumum beneficium multis mortalibus dare, uidelicet et sibi quisque conscius malo atque infido animo esse, de Marco Liuio Druso iuxta, ac de se existumauerunt. 5. Itaque metu ne per tantam gratiam solus rerum potiretur, contra eam nisi,sua ipseius consilia disturbauerunt. 6. Quo tibi, imperator, maiore cura fideique amici et multa praesidia paranda sunt.

II 6.4 "Mas os homens sediciosos, aos quais o dolo e a malícia eram mais importantes do que a confiança, quando compreenderam que por um só homem foi dado a muitos mortais o maior dos benefícios, cada um deles, culpado de ter um espírito ruim e traiçoeiro, julgou $\mathrm{M}$. Druso como a si mesmo. 5. Assim, com medo de que por tamanho reconhecimento pudesse ele sozinho resolver a situação, contra isso sabotaram não só os planos dele, mas também os seus próprios. 6. Por isto, deves procurar com muito cuidado, imperador, muita proteção e amigos fiéis”.

II 7.1 Hostem aduorsum deprimere strenuo homini haud difficilest; occulta pericula neque facere neque uitare bonis in promtu est. 2. Igitur, ubi eos in ciuitatem adduxeris, quoniam quidem reuocata plebs erit, in ea re maxume animum exerceto ut colantur boni mores, concordia inter ueteres et nouos coalescat. 3. Sed multo maxumum bonum patriae, ciuibus, tibi, liberis, postremo humanae genti pepereris, si studium pecuniae aut sustuleris aut, quoad res feret, minueris. Aliter neque priuata res, neque publica, neque domi, neque militiae, regi potest.

II 7.1 “Não é difícil para o homem perseverante derrotar o inimigo à sua frente: cabe aos bons não provocar nem evitar os perigos ocultos; 2. assim, quando os trouxeres à cidade, e 
assim ter verdadeiramente renovado a plebe, empenha maximamente o ânimo na tarefa de aumentar a concórdia entre os mais velhos e os novos, a fim de se cultivarem os bons costumes. 3. Mas terás alcançado um bem muito maior à pátria, aos cidadãos, a ti e aos filhos, enfim à humanidade inteira, se eliminares a ganância de dinheiro ou, até onde puderes, diminuí-la. Não há outra maneira de poder governar os assuntos íntimos ou a república, nem na paz ou na guerra”.

II 7.8 Postremo ubi diuitiae clarae habentur, ibi omnia bona uilia sunt, fides, probitas, pudor, pudicitia. 9. Nam ad uirtutem una ardua uia est, ad pecuniam qua quique lubet nititur: et malis, et bonis rebus ea creatur. 10. Ergo in primis auctoritatem pecuniae demito. Neque de capite neque de honore ex copiis quisquam magis aut minus iudicauerit, sicut neque praetor neque consul ex opulentia, uerum ex dignitate creetur. 11. Sed de magistratu facile populi iudicium fit: iudices a paucis probari regnum est, ex pecunia legi, inhonestum. Quare omnes primae classis iudicare placet, sed numero plures, quam iudicant.

II 7.8 "Por fim, quando se possuem riquezas honestas, ali estão todos os bens básicos: a confiança, a probidade, o pudor, a castidade; 9. porque há um só árduo caminho para a virtude; para o dinheiro cada um tome o caminho que lhe é conveniente - ele é gerado por bons e por maus atos. 10. Portanto, a primeira coisa a fazer é acabares com o poder do dinheiro. Que nenhum indivíduo seja julgado maior ou menor na dignidade ou na honra por suas posses, nem se crie um pretor ou cônsul com base na opulência, e sim na dignidade. 11 . Mas em relação à magistratura, o povo facilmente emite um juízo. É uma tirania os juízes serem nomeados por poucos, e desonesto serem escolhidos por sua riqueza. Por isso é conveniente que todos os da primeira classe julguem, mas em número maior do que os que julgam”.

II 8.4 Ceterum auaritia belua fera, immanis, intoleranda est; quo intendit, oppida, agros, 
fana atque domos uastat, diuina cum humanis permiscet, neque exercitus neque moenia obstant quominus ui sua penetret; fama, pudicitia, liberis, patria atque parentibus cunctos mortales spoliat. 5. Verum, si pecuniae decus ademeris, magna illa uis auaritiae facile bonis moribus uincetur. 6. Atque haec ita sese habere tametsi omnes aequi atque iniqui memorent, tamen tibi cum factione nobilitatis haud mediocriter certandum est. Quoius si dolum caueris, alia omnia in procliui erunt.

II 8.4 “Além disso a avareza, fera selvagem, cruel, é intolerável: aonde vai, devasta fortalezas, campos, templos e casas, mistura o divino ao humano, e não a obstam nem os exércitos e nem as muralhas para que não entre com sua força; despoja de todos os mortais a fama, a castidade, os filhos, a pátria e os pais. 5. Na verdade, se suprimires o respeito ao dinheiro, facilmente se vencerá pelos bons hábitos a terrível força da avareza. 6. Todos, os justos e os iníquos, lembram-se de que as coisas sucedem assim mesmo; todavia, deves não moderadamente resolver-te com a facção da nobreza, de cujas ameaças, se fugires, deixarás vulnerável todo o resto”.

De acordo com as passagens acima apresentadas, César deve promover a concórdia entre os cidadãos, por meio da recusa às riquezas; direcionar as atividades dos magistrados em favor do povo; evitar que os jovens se entreguem à ira e à cupidez; regular os negócios da plebe; por a salvo as colônias italianas pela justa recompensa aos veteranos de guerra; misturar nessas colônias os jovens e os idosos e, enfim, reafirmar os laços de amizade com seus aliados. Tais passagens, nas quais se evidencia a progressão do uso do tópico ex comparatione relacionado ao locus causarum reforçam, de um lado, as virtudes do orador e, de outro, as virtudes do homem político tal como delineados no capítulo anterior. Isso porque o apelo às virtudes de César para justificar suas ações serve não apenas para captar a benevolência da audiência do discurso, mas sobretudo retratar o próprio orador como uir probus, bene moratus e bonus, tal como Cícero e Quintiliano o definiram (Cíc. De Or. II 184; De Off. II 32; Quint. Inst. Or. I, 9-10). 
Cícero chama lenis ao estilo necessário para o orador quando se refere às virtudes do cliente (no caso de um julgamento) ou do destinatário do discurso (nas deliberações ou no elogio), mencionando que o uso desse estilo pode, às vezes, ser mais forte do que a própria causa (De Or. II 184, Horum igitur exprimere mores oratione iustos, integros, religiosos, timidos, perferentis iniuriarum mirum quiddam valet; et hoc vel in principiis vel in re narranda vel in perorando tantam habet vim, si est suaviter et cum sensu tractatum, ut saepe plus quam causa valeat; "É válido, de fato, expressar no discurso os seus costumes justos, íntegros, religiosos e tímidos, sobretudo ao sofrerem injúrias, e tal procedimento traz força quer na introdução, quer na narração ou na peroração, caso for tratado suave e sensivelmente para valer mais do que a própria causa”), sendo a brandura do orador nos gestos, nas palavras e na voz um elemento pelo qual se verificam, no discurso, as virtudes que ele mesmo possui para reconhecê-las em seu cliente:

De Or. II 43,182 Valet igitur multum ad vincendum probari mores et instituta et facta et vitam eorum, qui agent causas, et eorum, pro quibus, et item improbari adversariorum, animosque eorum, apud quos agetur, conciliari quam maxime ad benevolentiam cum erga oratorem tum erga illum, pro quo dicet orator. Conciliantur autem animi dignitate hominis, rebus gestis, existimatione vitae; quae facilius ornari possunt, si modo sunt, quam fingi, si nulla sunt. Sed haec adiuvant in oratore: lenitas vocis, vultus pudor [is significatio], verborum comitas; si quid persequare acrius, ut invitus et coactus facere videare. Facilitatis, liberalitatis, mansuetudinis, pietatis, grati animi, non appetentis, non avidi signa proferre perutile est; eaque omnia, quae proborum, demissorum, non acrium, non pertinacium? non litigiosorum, non acerborum sunt, valde benevolentiam conciliant abalienantque $a b$ eis, in quibus haec non sunt; itaque eadem sunt in adversarios ex contrario conferenda.

De Or. II 43,182 “Portanto, para vencer é muito válido aprovarem-se os hábitos, as decisões, as ações e a vida daqueles que defendem causas e daqueles a favor dos quais se defendem 
causas; da mesma forma, reprovarem-se os dos adversários; e quanto aos ânimos daqueles perante os quais se discursa, captar-se ao máximo possível a benevolência tanto em relação ao orador quanto em relação àquele que ele defende. Cativam-se os ânimos pela dignidade do homem, com suas ações e com a reputação dele. Essas coisas podem mais facilmente ser ilustradas se são verdadeiras, do que serem forjadas, se falsas. Isto auxilia o orador: a brandura da voz, um semblante calmo [e seus traços], o tom das palavras e, caso perseguir algo agressivamente, parecer fazê-lo a contragosto e coagido. É muito útil dar sinais da generosidade, da liberalidade, da mansidão, da piedade, da gratidão e não do apetite e da avidez. Essas coisas são o domínio de homens decentes, calmos, e não dos mal humorados, avarentos, rixosos e irascíveis; captam a benevolência com propriedade e se afastam daqueles que não as possui. Assim devem ser contrapostas às deficiências dos adversários”.

Nas Ep. ad Caes., as virtudes do orador aparecem na menção à experiência política (Ep. ad Caes. II 1, 3; II 12, 4), no amparo filosófico para justificar as mudanças que Roma sofreu com passar dos séculos (Ep. ad Caes. II 5, 3-5); na referência ao processo pelo qual as repúblicas mudam conforme o caráter de quem as governa (Ep. ad Caes. I 3.1 et seq.); como o homem deve cultivar seu espírito com as belas ações (Ep. ad Caes. I 7.5) e, enfim, a menção à decadência dos costumes (Ep. ad Caes. I 7,4), que inclui no número de degenerados os adversários de César e, naturalmente, exclui tanto a ele quanto aquele que o defende e aconselha. Assim sendo, a menção à experiência política e à urgência das ações do imperador visam, exatamente, a conferir autoridade ao orador. Essa tende a aumentar à medida que se sucedem, especialmente na argumentação, a enumeração das virtudes e das ações de César.

\section{De elocutione}

Parece não haver um rol específico de virtudes, tanto nas declamações em geral quanto nos praeexercitamina em particular, para aquela parte da elocução que constitui o ornatus. Sêneca, o 
Velho, por exemplo, ora aceita ora recrimina o uso de vulgarismos (Contr. I. 21; I 2,23 [contra o uso]; IV. 7; IX. 25 [admitindo o uso]), e mesmo Quintiliano (Inst. Or. VIII 3,22) não os nega quando o orador quer provocar o riso ${ }^{138}$. Da mesma forma, Sêneca, o Velho, admite o uso de um vocabulário comum (cotidianis verbis q.v. Contr. I 2,23; Suas. II. 13), de neologismos (Contr. VII 6,21), chegando enfim, se não a tolerar, pelo menos atestar a total liberdade no uso das palavras pelos declamadores (Contr. II, 1). Ele reclama apenas da obscuridade devida ao uso combinado de arcaísmos e de vulgarismos (Contr. II, 2).

À colocação de palavras (ordo), ao tamanho da oração (iunctura) e ao ritmo (numerus), Quintiliano chama vigor (Inst. Or. IX 4,22), o qual, nas declamações, recebe brilho graças às sententiae (Fairwhether, 1981, p. 202 citando Sen. Contr. I. pr. 23 e Quint. Inst. Or. VIII 5,1 et seq.; Nicolai in Zoido, 2008, p. 170) e a figuras de pensamento, como o iusiurandum, a ironia e a contradictio.

Quanto à escolha do vocabulário nas Ep. ad Caes. já existe uma extensa descrição, realizada por Marc Chouet (1950, pp. 9-44), que ressalta o uso de arcaísmos a despeito mesmo da intervenção dos copistas, responsáveis, sem dúvida, por um sem-número de correções do texto no intento de modernizar sua ortografia. Ainda assim, Chouet (citando a edição de Kurfess, 1930, pp. 20-21) noticia os arcaísmos (que aqui reproduzo) (cf. Clackson \& Horrocks, 2008, pp. 92-97):

a) / i / > / u / nas formas aestumant (II 8,7; 11,1) e existumauerunt (II 6,4); asperrume (I 1,6) e asperrumis (II 10,7); clarissumus (II, 12,5), deterrumi (I 4,3), maxuma (I 7,3; II 5,1), maxumam (II 13,2), maxume (I 1,2; 7,1; II 7,2; 12,3); maxumum (II 6,4; 7,3); maxumo (II 9,1; 13,5); pessumus (I 1,6) e lubet (II 1,4);

b) / o / > / u / nas formas uolgi (I 2,4) e uolgo (I 8,3);

c) prefixos não assimilados pela consoante seguinte em conruant (I 1,3); adfinitas (I 2,2);

138 Quintiliano (Inst. Or. II 4.4) diz que o aluno não precisa e nem deve ser avaliado pelo estilo. Dele é requerido apenas ter a mente fértil, ambição e um espírito imaginativo. O estilo deve ser a preocupação do orador maduro, a quem adotar soluções extravagantes para os casos reais constitui verdadeiro vício (Inst. Or. VI 1.43). 
inpendebat (I 2,6); inmanis (II 8,4) e conrigenda (II 10,1);

d) / p / > / b / em optinebat (I 1,1), apsolui (I 8,7), apsurde (II 8,1), opsecutus (I 6,5), optestor (II 13,8), optrectatoribus (II 13,7) e pleps (I 7,2);

e) quoi substituindo cui em quoius (II 1,1; 1,4; 3,2; 8,6; 9,2), quoiusquam (II 12,7), quoiquam (II 1,1) e quoique (I 5,4; II 12,8);

f) uo substituindo ue em peruorse (I 1,5), peruorsam (I 7,5), aduorsum (I 1,8; 4,3) e diuorsa (II 12,7) e quom no lugar de cum;

g) / t / > / d / em haut (I 8,4);

h) / u / > / e / nos gerundivos faciundo (I 1,2; II 1,6; 4,2), dicundo (II 4,2), reprehendunda (I 8,9);

i) sinizese em dictust (I 2,7), difficilest (II 7,1);

j) / i / > / ei / em ineiquorum (I 2,5), formeidatur (I 1,4), tuei (II 4,5), ipseius (II 6,5), libidinei (I 5,5), qualeicumque (I 1,1), illei (I 1,5), fidei (II 6,6), ignarei (II 10,9), quei (II 12,1), mortaleis (I 1,1), quieteis (I 2,5), aequeis (II 3,2), alieis (I 8,1), illeis (II 9,4), haberei (I 1,3; II 1,4), inuisier (II 12,7), nequeiret (I 7,1), nequeicquam (I 8,2), utei (I 1,9; II 13,3), sicutei (II 4,2), quein (II 4,2);

k) infinitivo passivo em -ier (II 12,7 inuisier);

l) terceira pessoa do plural do pretérito perfeito do indicativo ativo em -ere nas formas verbais fuere (I 1,5), defluxere e restitere (I 2,6), temperauere (I 3,3), tribuere (I 3,4), oppressere (I 8,2), nequiere (II 4,2), coepere (II 5,4), peruenere (II 9,4), corrumpere (II 10,3), distinuere e fecere (II 11,6);

m) o verbo pollere no sentido de ualere (II 7,4).

No que concerne à imitação de Salústio, entretanto, lembro que o autor das Ep. ad Caes. tanto imita passagens da obra do historiador para justificar sua autoridade no aconselhar - o que foi analisado com mais cuidado na seção destinada aos argumentos éticos das Ep. ad Caes. - quanto 
imita aquilo que se sobressai em Salústio como sendo o seu estilo. Em relação a isso, e a par das identificações entre Ep. ad Caes. II 1, 3; II 2, 4; II 12, 5 = Bel. Cat. 5, 9; 6, 5; 29, 3; 53, 2; Bel. Iug. 14, 1; 31, 25 e Ep. ad Caes. I 5, 1 = Bel. Cat. 19, 5; e Bel. Iug. 19, 8, Chouet (1950, pp. 12-22) também distribui as influências de Salústio no vocabulário das Ep. ad Caes. da seguinte maneira (que aqui resumo) ${ }^{139}$ :

a) substantivos e adjetivos:

1.cupido (Ep. ad Caes. II 7,4; 12,4 cp. Bel. Cat. 3,5; 7,3; 10,3 etc.) no lugar de cupiditas;

2.a expressão domi militiaeque (Ep. ad Caes. II 1,3; 2,3; 13,5 cp. Bel. Cat. 5,9; 6,5; 9,1; 29,3; 53,2; Bel. Iug. 14,1; 31,25);

3.excidium (Ep. ad Caes. I 5,2 cp. Hist. Frag. I 10; 67, 10), termo desconhecido de Cícero e de César;

4.factio e factiosus (Ep. ad Caes. II 2,4; 3,3; 4,2; 6,4; 8,6; 9,4; 10,8-9; 11,6 cp. Bel. Cat. 34,2; Bel. Iug. 31, 1 etc.) identificando os membros da nobreza;

5.mortaleis no lugar de homines (Ep. ad Caes. I 1,1; 2,7; 8,9; II 1,1; 1,6; 8,4; 11,4; 12,7; 13,6 cp. Bel. Cat. 1,5; 2,8; 6,4; 10, 5 etc. Bel. Iug. 1,5; 6,3; 10,2 etc.);

6.vocábulos raros, como opulentia e socordia (Ep. ad Caes. I 5,5; II 3,6; 4,2; 10,9 [socordia]; II 1,3; 7,5-6 [opulentia] cp. Bel. Cat. 4,1; 52,29; 58,4; Bel. Iug. 1,4; 2,4; 31,3; 36,3; 55,1; 70,5; 79,5; 85,22 [socordia]; Bel. Cat. 6,9; 52,9; 59,22 [opulentia]; 7.tempestas no lugar de tempus (Ep. ad Caes. I 5,2; II 11,6; 13,5 cp. Bel. Cat. 7,1; 22,1; 53,5; Bel. Iug. 8,1; 30,4; 35,1; 37,1; 65,5), especialmente em construções com ablativo absoluto.

139A lista de Chouet inclui ainda preposições e conjunções, mas com a finalidade de filiar as Ep. ad Caes. aos textos autorais de Salústio; para isso, o autor verifica o uso dessas classes de palavras de maneira a demonstrar a evolução do estilo de Salústio (1950, p. 20) e destaca quais foram usadas no século I a.C. com o mesmo sentido nas obras do historiador e em Cícero. Assim, em vez de encontrar peculiaridades do estilo de Salústio, o autor se concentra em descrever o que lhe era genérico. Por essa razão, descarto a reprodução integral de sua lista porque sigo a máxima de Quintiliano, segundo a qual se deve imitar o que há de específico no modelo. 
b) verbos e advérbios:

1.coalescere (Ep. ad Caes. II 7,2; cp. Bel. Cat. 6,2; Bel. Iug. 87,3), conglobare (Ep. ad Caes. I 5,2; cp. Bel. Iug. 97,4), dispalari (Ep. ad Caes. II 5,6; cf. com palari em Bel. Iug. 18,2), fatigare (Ep. ad Caes. II 10,5; 13,7; cp. Bel. Cat. 11,7; 27,2; Bel. Iug. 3,3; 11,4; 14,20; 56,1; 66,2; 70,1; 73,2; 76,5; 94,3; 111,3) são verbos peculiares a Salústio;

2.aliter (Ep. ad Caes. I 5,2; cp. Bel. Cat. 29,3; 44,1); at contra (Ep. ad Caes. I 1,6; cp. Bel. Cat. 12,5; Bel. Iug. 4,7; 15,3; 16,2; Hist. II 47,2); contra ea (Ep. ad Caes. II 10,9; cp. Bel. Iug. 57,5; 85,1); contra (Ep. ad Caes. I 3,3; cp. Bel. Cat. 20,10; Bel. Iug. 97,3; Hist. III 109) são advérbios peculiares a Salústio.

Convém lembrar, no entanto, que a arte converge para os ornamentos do discurso quando exercitada (De Or. III 31, 125), e que a imitação não é resultado da escolha de apenas um modelo, mas do que há de aprovado em mais de um modelo de maneira a produzir a riqueza de temas e a riqueza de expressão.

Ainda que Salústio seja o modelo das Ep. ad Caes. por excelência, o vocabulário delas recorre ainda aos arcaísmos de Plauto em várias passagens (Ep. ad Caes. I 4,4 scorta aut conuivia exercuerint; cf. Am. 288 haec nox scita est exercendo scorto; Ep. ad Caes. II 7,4 satis pollet; cf. As. 636 quid pollent quidue possunt; uso de iuxta como advérbio em Ep. ad Caes. II 6,4; 7,12; 11,4; cf. Mil. Gl. 233-234 ut scias/iuxta mecum) (Chouet, 1950, pp. 15-17) para conferir brilho ao ornatus.

A par dos arcaísmos, apresento ainda duas ocorrências de vocabulário comum, característico das declamações conforme a menção de Sêneca, o Velho (cotidianis verbis q.v. Contr. I 2,23; Suas. II. 13), nas passagens (grifo meu) Ep. ad Caes. I 1,9 quod multo multoque asperius est, pacis bonis artibus e Ep. ad Caes. II 7,4 quin animus magis aut minus mature, postremo tamen subcumbi; II 7,10 neque de capite, neque de honore ex copiis quisquam magis aut minus iudicauerit.

Quanto à disposição das palavras na oração (ordo), Chouet (1950, pp. 25-28), ressalta o 
predomínio da ordem sujeito + predicado nas Ep. ad Caes., ocasionalmente havendo construções iniciadas por verbo ou findas pelo sujeito (cf. Ep. ad Caes. I 4,4; 5,3; 5,7; 7,2; 8,2; II 1,1; 6,1; 8,2; 12,3). Quanto ao ritmo (numerus), Chouet (1950, p. 31) noticia a distância entre as cláusulas existentes nas Ep. ad Caes. (em que há predomínio do duplo espondeu e do duplo crético) e na oratória ciceroniana (em que predominam o ditroqueu, o crético seguido de um espondeu e o peão primeiro seguido de um troqueu), bem como a pouca coincidência com as cláusulas salustianas (em que predominam o duplo espondeu, o dáctilo seguido de troqueu e espondeu seguido de crético). Quanto ao tamanho da oração (iunctura), por sua vez, o autor atesta o predomínio da hipotaxe e a ocorrência de arcaísmos. Esses últimos sobressaem-se nos seguintes trechos (Chouet, 1950, pp. 2225):

a) uso de advérbios como atributos em I 6,1 se in victoria licentius liberiusque quam arctius futuros credebant (cp. Sal. Iug. 87, 4 laxius licentiusque futuros) e I 1,5 quia plerique rerum potentes peruorse consulunt;

b) oração infinitiva introduzida por verbo de percepção + conjunção (sic, ita) em I, 1,10 mihi sic uidetur; I 5,2 ego sic existimo; II 6,2 e 10, 4 sic apud animum meum statuo; II 10,3 ego ita comperi;

c) concordância lógica entre sujeito e verbo em I 2,6 magna pars... defluxere; pauci restitere.

Mais do que da correção (emmendate dicentium praemium) e da clareza (lucide dicentium praemium), convém ao orador os prêmios do ornato, o qual, segundo Quintiliano (Inst. Or. IX 3,13), é responsável pela simultânea recomendação de arte do orador e da causa defendida. Isso porque o ornato pode ser julgado pelos mais experientes, de um lado e, de outro, admirado pelo público em geral. No entanto, não pertence ao gênero deliberativo, ao demonstrativo e ao judiciário o mesmo tipo de ornato; ao gênero demonstrativo, devotado à ostentação da arte, pedem-se sentenças, nitidez 
de vocabulário, profusão de figuras, grandeza de metáforas e elaborada composição (Inst. Or. IX 3,12), enquanto nos demais gêneros o ornato deve ser mais austero, menos óbvio e apropriado à causa (Inst. Or. IX 3,13). Quanto à colocação de palavras, a opção pelos sinônimos e pelos vocábulos de som mais harmonioso afasta o discurso de uma linguagem mais ordinária, enquanto a opção pelo arcaísmo tende a inflar o discurso quando incide na obscuridade, uma vez que o excesso de arcaísmos lembra afetação (Inst. Or. IX 4,25-27; cp. Cíc. De Or. III, 10.39). Nisso, Quintiliano retoma Cícero (De Or. III, 38.152-153), para quem os arcaísmos, os neologismos e as palavras tomadas metaforicamente conferem brilho e ornato ao discuso, conquanto os arcaísmos pesem a favor dos poetas, e não dos oradores.

Já a sententia, figura definida por Quintiliano, na seção destinada à colocação de palavras (ordo), como o principal dos ornamentos (Inst. Or. IX 5,29; para alguns é mesmo o único: q.v. Inst. Or. I 8,9), pode ser composta de várias figuras (ibid.), funcionando, tal como o entimema (Inst. Or. IV 14,1; Fairwhether, 1981, p. 203), depois de a audiência ter sido persuadida pelo argumento (Inst. Or. IX 5,10; Fairwhether, 1981, p. 204).

Não há consenso sobre os tipos de figura que compõem a sententia, nem que tipos de figura devem integrar uma declamação, porque dissentem nesse quesito tanto Sêneca, o Velho, quanto Quintiliano (Fairwhether, 1981, p. 210). Quintiliano, porém, diz que as sententiae não devem ser frequentes, nem falsas, nem usadas indiscriminadamente por qualquer um, porque são apropriadas apenas para homens de autoridade (Inst. Or. IX 5,7). As Ep. ad Caes. fazem largo uso delas, dispostas, não por acaso, em

I 1,4 qui plus potest tamen, quia malo esse licet, formeidatur;

I 1,4 “Quem pode muito é temido, todavia, porque lhe é permitido ser mau”.

I 7,1 magnae curae magnae merces est;

I 7,1 “Grandes prêmios provêm de grandes cuidados”. 
I 3,2 cuncta imperia crudelia magis acerba quam diuturna;

I 3,2 “Todo o poder cruel é mais severo do que duradouro”.

I 3,2 quemquam multis metuendum esse quin ad eum ex multis formido reccidat;

I 3,2 “[Imagino que] não haja alguém que a muitos assuste sem que de muitos tenha medo”.

I 5,2 orta omnia intereunt (cp. Sal. Bel. Iug. 1,2 omniaque orta occidunt)

I 5,2 “Tudo o que nasce, morre” (cp. Sal. Bel. Iug. 1,2 “e tudo o que nasce, fenece”).

I 6,2 sapientes pacis causa bellum gerunt, laborem spe otii sustentant;

I 6,2 “Os sábios travam guerras em benefício da paz, suportam o cansaço na esperança do repouso".

\section{8,2 imprudentia pleraque et se praecipitat;}

I 8,2 “É a imprudência que muitas vezes destrói a si mesma”.

II 1,2 plerasque res fortuna ex libidine sua agitat.

II 1,2 “A fortuna promove muitas coisas segundo sua própria vontade”.

Os tratados de Teão, Hermógenes (e a tradução latina de Prisciano), Aftônio, Nicolau e Libânio, entretanto, opõem ao caráter universal das sententiae o caráter particular da anedota (chría). A sententia explora o que é ou o que poderia ser considerado um valor universal, justificando-se por si mesma e isenta da menção a um contexto ou a um falante específico, enquanto a anedota demonstra, brevemente, o que pensa ou como age um personagem em particular (Th. Prog. 96-97; Herm. Prog. 9; Af. Prog. 7-8; Nic. Prog. 19,25; Prisc. Praex. 30). Considerando-se, portanto, a expressão do que pensa e como age um personagem em particular, considero como 
anedota, na Ep. ad Caes. I 1,2, quod in carminibus Appius ait fabrum esse suae quemque fortunae (“o que Ápio diz em seu poema: “cada um é artífice de sua própria sorte”).

Tanto a chría quanto a sententia consistem em exercícios relacionados aos verba coniuncta (Quint. Inst. Or. X 5, 1-23; Lausberg, 1974, §1097), integrando aqueles que dão tratamento distinto à mesma matéria. A sententia, pelo fato de não se limitar a um caso particular, é especialmente útil por conferir auctoritas ao orador e por servir à tarefa de aconselhar (Quint. Inst. Or. VIII 5, 3 sententiae vocantur, quas Graeci gnomas appellant: utrumque autem nomen ex eo acceperunt quod similes sunt consiliis aut decretis. Est autem haec vox universalis, quae etiam citra complexum causae possit esse laudabilis, interim ad rem tantum relata; “denominam-se sentenças aquilo que os gregos chamam gnomas: uma e outra receberam essa denominação porque são semelhantes aos conselhos ou às ordens. Trata-se de uma afirmação universal, que pode ser louvada a despeito do nexo da causa, ao mesmo tempo em que se relaciona com a matéria”), valendo tanto como sabedoria popular quanto doutrina filosófica. Ademais, ela respeita a virtude da brevidade, devido a sua inclinação para a sutileza do esclarecimento, e tanto pode ser inserida na argumentação quanto na narração (Lausberg, 1974, §§ 877; 879). A chría, por sua vez, é para a sententia o que a questão finita é para a infinita; essa é geral, aquela é particular (Lausberg, 1976, § 1117).

Assim é que a elocução das Ep. ad Caes. é constituída não só pela imitação de Salústio, mas também pela imitação de outros autores e pelo uso de sententiae. A imitação também é decisiva em relação à construção da credibilidade do orador e à eleição da matéria da obra. Procedendo dessa forma, o orador obedece ao princípio de que a arte deve ser ocultada pelo engenho (Rhet ad Her. IV 3), uma vez que ela permite, também, fazer uso de exemplos alheios (Rhet ad Her. IV 3). Do orador é esperado escolher e ordenar, sob métodos preceptivos, tudo o que é mister escrever (Rhet ad Her. IV 4); da audiência, por sua vez, é esperada a aprovação do orador sabendo o que é e onde reside aquilo que, em seu discurso, causa deleite (Rhet ad Her. IV 4). De ambos, espera-se a ciência de que (Rhet ad Her. IV 7), se existe arte em compreender o que foi escrito com arte, muito mais existe em escrever com arte. 


\section{Conclusão}

Considerado uma construção, na qual as afecções entram em jogo com a finalidade de produzir a credibilidade em relação ao que é dito, o discurso trata de dois tipos de comoção - aquela introduzida pelo orador na audiência (e.g., a captatio beneuolentiae) e aquela por ele construída e apresentada no discurso (Chiappetta, 1997, pp. 104-105). Isso posto, distribuem-se as provas técnicas e as tarefas do orador. Seu sucesso advirá da solução dada ao problema prático de fazer com que a audiência creia no que o orador diz, o que somente pode ser resolvido pela associação entre a persona construída no discurso, as ações e afecções por ele confrontadas, a elocução aplicada e a performance (Chiappetta, 1997, pp. 105).

Assim é que, nas Ep. ad Caes., a construção, por parte do orador, da figura do uir bonus dicendi peritus e de uma personagem cujos atributos (bonus, strenuus, clemens, dignus, clarissimus) fazem-na portadora dos demais corolários das uirtutes principis (uirtus, iustitia, clementia), deve ser entendida como uma forma de compor e equilibrar as provas técnicas, e revelar não o caráter de um indivíduo real exposto pelo discurso, e sim o efeito provocado pelo gênero de discurso. Dada a consequência nefasta de uma circunstância, como é a de uma guerra civil, é natural esperar que alguém de autoridade aconselhe a outrem de sumo poder a agir com prudência, sabedoria, clemência e virtude no intuito de garantir a paz e fazer aquilo que é útil e honesto a todos dentro da cidade. Duas vezes conveniente, o conselho formaliza as virtudes do homem político - colaborando para a disseminação, no tempo e no espaço, dessas virtudes dentro do grupo social - e coroa ainda a arte do orador, porque respeita o decoro exigido pelo gênero deliberativo.

As Ep. ad Caes. respeitam os pré-requisitos que o orador deve conhecer para aconselhar: o 
conhecimento da política (Ep. ad Caes. I 7,4; II 1,3; 5,1; 12,4; cp. Rhet. ad Her. I. 7-8; Inst. Or. I, 910) o discursar com verossimilhança (Ep. ad Caes. I 3,2; 4,3; II 1,3; 3,1; 5,1-8; cp. De rep. II.45; De Off. I.81; II.33) e o uso de um estilo elevado e ilustre (De Or. II 82.337 Ad consilium autem de re publica dandum caput est nosse rem publicam; ad dicendum vero probabiliter nosse mores civitatis [...]; et quamquam una fere vis est eloquentiae [...] genus quoque dicendi grandius quodam et inlustrius esse adhibendum videtur; "Para dar um conselho sobre a administração pública é necessário conhecer a república; para discursar, conhecer comprovadamente os costumes da cidade [...]; e, mesmo que a força da eloquência esteja presente em toda a parte, é também reconhecida a necessidade de se compor um discurso um tanto mais elevado e ilustre”).

Os documentos cumprem, ademais, a finalidade do discurso deliberativo (aconselhar sobre o que é útil; cp. Part. Or. 83-86; 90-91; De Or. II 82.335; Inst. Or. III 4, 16; III 8, 22), nas passagens Ep. ad Caes. I 8.7 (com base no que foi apresentado em I 3.1; I 5.1 - 7.5), II 12.3 e II 13.8 (com base no que foi apresentado em II 7.2-12; II 8.1-3; II 10.1 - 12.8). A fim de reforçar o conselho por meio do movimento das afecções (cf. Cíc. De or. II 82, 337) e tornar o ouvinte dócil, benevolente e atento, os documentos apresentam argumentos relativos à noção de dever, o qual se subdivide nas partes da utilidade e da honestidade. Quanto à utilidade, os argumentos destinam-se à manutenção e ao aumento da utilidade comum e concentram-se, essencialmente, na conclusão da guerra (3.1 3.4) e no impedimento do conflito (II 5,1 - 12,4). Quanto à honestidade, destinam-se à obtenção do bem, relativo à preservação da vida em comunidade, e concentram-se, essencialmente, na restituição da liberdade, na moralização dos cidadãos (II 7,2 - 8,2; 13,3) e na afirmação da paz (I $5,1-8,6)$

Como a utilidade (Rhet. ad Her. III. 3) é dividida em duas partes - a parte segura (tutam) e a honesta (honestam), as Ep. ad Caes. valem-se dos tópicos da causa honesta nas passagens Ep. ad Caes. I 2.2; II 3.1; I 2.5-6; II 3.2-4; I 2.4. II 3.6-7; I 2.7; II 4.2 tanto para mover o ânimo quanto para estabelecer a credibilidade do discurso. Esse tipo de causa trata das ações retas e louváveis, especialmente aquelas que são realizadas com virtude e dever ou aquelas que geram lembrança 
honesta no presente e no futuro (q.v. Rhet. Ad Her. III. 8-9). Nas Ep. ad Caes., essas ações são enumeradas na confirmação com base nas virtudes de César (I 3. 2 - 8. 6; II 5.1 - 12.4).

A fim de estabelecer a credibilidade do discurso, cada parte é submetida a regras que direcionam a matéria: o exórdio e a peroração das Ep. ad Caes., portanto, procuram cativar a audiência pela construção da imagem do orador e do destinatário do discurso (conciliare); a narração, influenciar a audiência graças à enumeração das virtudes de César (mouere) e a confirmação, conquistar a adesão da audiência pelos argumentos relativos à ação do imperador (docere).

Em relação ao exórdio e à peroração, o orador menciona, como método, a experiência política dele e de César; diferencia a situação passada e a presente e demonstra a intenção de aconselhar útil e prudentemente. Na narração, por sua vez, a construção da imagem do destinatário solicita a menção à justiça, à prudência, à coragem e à modéstia, virtudes que caracterizam a causa honesta; as Ep. ad Caes., entretanto, suprimem a prudência e incluem a clemência, sendo essa a virtude distintiva do imperador. Na confirmação, por fim, o propósito do gênero deliberativo aconselhar sobre o que é útil e necessário - é cumprido pela argumentação sobre os meios para se conseguir os bens e se evitarem os males (restituir a liberdade; moralizar os cidadãos; firmar a concórdia entre jovens e velhos) e sobre o aumento e a manutenção da utilidade comum (concluir a guerra; firmar a paz). A argumentação requer o conhecimento do funcionamento da cidade, e por isso é possível perceber elementos da constituição republicana (a menção à decadência dos costumes visa explicar como a república perdeu a firmitudo e a aequabilitas iuris) misturados aos do principado (o poder centralizador reverte os males da decadência graças ao exercício da clemência e da moderação). A imitação de Salústio, no exórdio e na confirmação, preenche, dessa maneira, um esquema prévio de formulação do discurso, pois é graças à menção das virtudes do homem público, da experiência do orador e da decadência dos costumes somados à finalidade do gênero deliberativo que o conselho ganha base e se sustenta. 
Não apenas os documentos cumprem os pré-requisitos para o aconselhamento e a finalidade do gênero deliberativo, como ainda obedecem à submissão das partes do discurso às provas técnicas e às tarefas do orador.

Quanto ao exórdio - que estabelece o gênero da causa, separa o que é justo do que é injusto e amplifica a matéria a fim de acomodar a causa e dispor o ouvinte à persuasão (Cíc. De Or. De or. II. 80; II 27, 115; cf. II 28, 121; 29, 128; 77, 310; De inv. I xv. 20; Part. Or. 28; Or. 122; Top. 97; Quint. Inst. Or. IV 1, 5; Lausberg, 1994, §§ 263-288) - o orador elogia César, na primeira epístola, devido à importância de seus feitos, à amenidade que ele demonstrou após a vitória e à sua virtude, que se sobressai à sua boa fortuna. Na segunda epístola, por sua vez, lembra a própria experiência política e a humildade necessária para aconselhar um imperador corajoso sobretudo na adversidade.

Quanto à narração - que estabelece a credibilidade do orador e prepara os argumentos para a confirmação (Rhet. ad Her. I. 12; 14; Cíc. De inv. I xix, 27; Part. Or. 31; De or. II 326-329; Quint. Inst. Or. IV. 2. 40-52; Lausberg, 1994, §§ 289-347) - na primeira epístola, o orador adianta as ações de César como justas e relembra as atrocidades cometidas por Pompeu antes da guerra civil. Na segunda epístola, o orador expõe os eventos passados que desqualificam seu oponente para a gerência da república, vinculando seu nome ao de Sula. Em ambas as epístolas, predomina o ataque a Pompeu, tido ora como general sem capacidade para liderar devido à falta de virtude, ora como cruel com os concidadãos, ora como responsável pelo desconcerto da república.

Assim também na confirmação - que apresenta o conhecimento do orador sobre o funcionamento da cidade através de uma argumentação racional (Cíc. De or. II 330-332; Part. or. 27; q.v. De inv. I xxiv.34; Quint. Inst. Or. IV 2, 79; q.v. Quint. Inst. Or. V. 1, 1; Lausberg, 1994, §§ 348-430) - o orador argumenta, na primeira epístola, sobre o que César deve fazer para a conclusão da guerra e sobre o que deve fazer para a afirmação da paz; na segunda epístola, por sua vez, o que César deve fazer para evitar o conflito.

Por fim, na peroração - que dispõe o ouvinte a favor da causa (Cíc. De inv. I lii.98; Rhet. ad 
Her. II 30,47; Quint. Inst. Or. VI 1,1-7; 27-28; Lausberg, 1994, §§ 431-442) - o orador promove o aconselhamento usando da sua própria pessoa e deseja sorte ao imperador para a realização do que seja o mais correto a fazer, reforçando ainda a sua grandeza para a realização das ações que pleiteia. Na primeira epístola, busca-se a conquista (conquestio) da simpatia em causa própria e, na segunda epístola, a amplificação e a personificação, prosopopeia reforçam o caráter grandioso dos feitos de César pela menção ao poder da fortuna sobre o devir dos homens.

Malgrado a correspondência entre a preceptiva teórica, as lições da história e da filosofia e a arte do orador, assunto desta tese como um todo, poder-se-ia contestar a definição das Ep. ad Caes. como um exemplo de exercício retórico e defender-se a ideia de que elas sejam, entretanto, textos autênticos de Salústio. Caso é o de Marc Chouet, que ora se refere ironicamente ao autor delas como um "Salústio ressuscitado” ora devotadamente como um "político letrado” [scilicet, o próprio Salústio], com base nas semelhanças dos documentos tanto em relação às obras autorais salustianas quanto ainda à Guerra Civil de César, e daí sugerindo um vínculo pessoal de amizade e cumplicidade entre as personagens históricas que se reflete naquilo que compõe a matéria das epístolas. Tais correspondências revelam-se, para Chouet, nas ideias filosóficas, morais e políticas apresentadas nos dois documentos (1950, pp. 79-99).

Quanto às ideias filosóficas existe unanimidade, entre os autores, em afirmar que a agitação da guerra civil é um evento para o qual a vontade humana conta pouco face ao acaso ou a um fado desordenado $^{140}$. Disso deriva que a uirtus de César deve subordinar o acaso pelo valor das ações do homem $^{141}$. Ao confrontar a virtude e a fortuna, explicar-se-ia ainda o porquê de as próprias epístolas

140 cp. Ep. ad Caes. II 1,2 plerasque res fortuna ex libidine sua agitat; Sal. Bel. Cat. 8 Sed profecto fortuna in omni re dominatur; Cés. Bel Civ. III 68,1 Sed fortuna, quae plurimum potest cum in reliquis rebus tum praecipue in bello.

141 cp. Ep. ad Caes. II 7,7 Quippe gloria industria alitur: ubi eam demseris, ipsa per se uirtus amara, atque aspera est [...] 9. Nam ad uirtutem una et ardua uia est, ad pecuniam qua quique lubet nititur:et malis, et bonis rebus ea creatur; II 13,7 Nam uiuos interdum fortuna, saepe inuidia fatigat: ubi anima naturae cessit, demptis obtrectationibus, ipsa se uirtus magis magisque extollit; Cés. Bel Civ. III 73,4 Si non omnia caderent secunda, fortunam esse industria sublevandam; Sal. Bel. Cat. 1,2 Quod si regum atque imperatorum animi virtus in pace ita ut in bello valeret, aequabilius atque constantius sese res humanae haberent neque aliud alio ferri neque mutari ac misceri omnia cerneres [...] Verum ubi pro labore desidia, pro continentia et aequitate lubido atque superbia invasere, fortuna simul cum moribus inmutatur; Sal. Bel. Ing. 1,4 Nam saepe ego audivi Q. Maximum, P. Scipionem, praeterea civitatis nostrae praeclaros viros solitos ita dicere, cum maiorum imagines intuerentur, vehementissime sibi animum ad virtutem accendi. 
contrariarem-se nos passos Ep. ad Caes. I 1,2 fabrum esse suae quemque fortunae ("cada um é artífice de sua própria sorte”) e Ep. ad Caes. II 1,2 plerasque res fortuna ex libidine sua agitat (“a fortuna promove muitas coisas segundo sua própria vontade”): ambas serviriam para validar as ações de César quer pela proteção da fortuna, em que se diz ter a personagem se amparado com bastante frequência, quer pelo valor próprio da uirtus, que fabrica o destino de cada um e deve ser mantida com enorme esforço.

Quanto às ideias morais, seria comum a César e a Salústio - entendidos como os agentes históricos - a necessidade de resistir à corrupção moral e à decadência dos costumes, o que se traduz num padrão de ação política. As ideias políticas que reforçam esse padrão referem-se ao patriotismo desinteressado, que caracterizava os primeiros romanos, comparado à falta de concórdia entre os ordines por conta da degeneração moral ${ }^{142}$. A decadência dos costumes revelaria, assim, a oposição do historiador à nobreza e mesmo à miséria material e moral da plebe ${ }^{143}$.

A alegação de que as epístolas sejam autênticas, portanto, apóia-se na busca de identificações de ideias entre Salústio e César, mas não explica o porquê do uso de arcaísmos e de sententiae, da divisão ordenada da matéria e da imitação da Conjuração de Catilina e da Guerra Jugurtina em uma correspondência particular. A meu ver, não haveria razão para Salústio imitar-se a si mesmo numa epístola, nem para dividir a matéria ordenadamente num discurso que não demanda cuidados específicos em relação à disposição, nem mesmo para valer-se de uma elocução ornada e de um estilo elevado quando o destinatário das epístolas é um indivíduo com quem, ademais, Salústio teria possuído uma relação de amizade e de proximidade. Quero dizer com isso que, tal como chegaram a nós, as Ep. ad Caes. não responderiam ao decoro do gênero (sermo), nem

142 ср. Ep. ad Caes. II 10, 7. Itaque maiores nostri, quum bellis asperrumis premerentur, equis, uiris, pecunia amissa, nunquam defessi sunt armati [...] corpus atque ingenium, patriae, non suae quisque potentiae, exercitabat; Sal. Bel. Cat. 6 brevi multitudo dispersa atque vaga concordia civitas facta erat.

143 ср. Ep. ad Caes. II 3,2 Primum omnium, summam potestatem moderandi, de uectigalibus, sumtibus, iudiciis, senatoribus paucis tradidit; plebem romanam, cuius antea summa potestas erat, ne aequis quidem legibus, in seruitute reliquit; Ep. ad Caes. II 5,5 Ita paulatim populus qui dominus erat, et cunctis gentibus imperitabat, dilapsus est et pro communi imperio priuatim sibi quisque seruitutem peperit; Sal. Bel. Iug. 85 Scio ego, Quirites, plerosque non isdem artibus imperium a uobis petere et, postquam adepti sunt, gerere: primo industrios supplices modicos esse, dein per ignauiam et superbiam aetatem agere. 
ao decoro da espécie (epistula), nem mesmo ao decoro da elocução, no caso de serem consideradas autorais.

Com efeito, a distinção entre os gêneros da arte consiste, essencialmente, no decoro ou propriedade existente entre a matéria e as palavras. Cícero, por exemplo, comenta o total equívoco que há em se usar um estilo elevado, diante de um só juiz, na defesa em juízo de casos, por exemplo, como os de estilicídio, ou ainda de um estilo remisso num discurso pronunciado diante do povo romano. Isso porque, se a palavra perde a força sem a matéria, então a matéria é também aprovada ou rejeitada de acordo com as palavras pelas quais é expressa (Or. xxi. 72; cp. De Off. I 40.144).

Tendo em conta a noção do decoro referente ao aconselhamento, Sêneca diferencia a conversação (sermo) do discurso oratório (disputatio), dizendo que esse é preparado e revestido de mais aparato, quando aquela é composta de palavras mais despretenciosas para penetrarem no entendimento de forma mais rápida e fácil (Ep. Mor. 38 Plurimum proficit sermo, quia minutatim irrepit animo: disputationes praeparatae et effusae audiente populo plus habent strepitus, minus familiaritatis; “A conversação é muito mais eficiente, porque num minuto introduz-se no ânimo: os discursos oratórios preparados e profusos possuem mais estrépito diante do povo, e menor familiaridade”). Disso deriva que o sermo não é um gênero de discurso destinado ao público, quando o é a disputatio (ibid., Philosophia bonum consilium est: consilium nemo clare dat; “A filosofia é um bom conselho: ninguém dá conselho em público”); daí a filiação do sermo ao conselho do filósofo e da disputatio, ao conselho do orador. Assim é que o estilo do filósofo é humilde, quando o estilo do orador é grave, porque o filósofo quer ensinar e o orador, mover os ânimos: Aliquando utendum est et illis, ut ita dicam, contionibus, ubi qui dubitat impellendus est; ubi vero non hoc agendum est, ut velit discere, sed ut discat, ad haec submissiora verba veniendum est. Facilius intrant et haerent; nec enim multis opus est sed efficacibus (ibid. "às vezes é necessário valer-se do debate público, por assim dizer, no qual aquele que duvida deve ser persuadido; mas quando não se pretende fazer com que se queira aprender, e sim que se aprenda, deve-se recorrer a 
um vocabulário mais remisso: facilmente penetra e se fixa; nem é preciso o excesso, e sim a eficiência”). Isso faz da epístola uma espécie mais conveniente ao filósofo e o discurso deliberativo, ao orador, pois esse dirige-se a uma audiência num estilo grave, quando aquele dirige-se a um só ou a poucos num estilo humilde: Merito exigis ut hoc inter nos epistularum commercium frequentemus. Plurimum proficit sermo, quia minutatim irrepit animo: disputationes praeparatae et effusae audiente populo plus habent strepitus, minus familiaritatis (ibid. “com razão exiges que aumentemos a troca de correspondência: a conversação é muito mais eficiente, porque num minuto introduz-se no ânimo: os discursos oratórios preparados e profusos possuem mais estrépito diante do povo, e menor familiaridade”; cp. Hor. Ep. 2.1.4; 2.2.22; Cíc. Ad Att. 1.9.1; Fam. 9.21.1; 13.19.3; Rhet. Ad Her. III 23).

Cumpre ainda dizer que, se o discurso oratório (disputatio, contentio) possui regras específicas e determinadas pelos rétores, o mesmo não se dá com a conversação (sermo) ou, caso se desse, pelo menos não seria da mesma forma como ocorre no discurso oratório (Cíc. De Off. I 37.132 Contentionis praecepta rhetorum sunt, nulla sermonis, quamquam haud scio an possint haec quoque esse; "pertence aos rétores a preceituação do debate público, nada em relação à conversação, embora eu não saiba se é possível ou não prescrevê-la”), muito embora valha para o sermo os mesmos preceitos que se aplicam à disputatio no que concerne às palavras, a saber, a suavidade e a clareza (Cíc. De Off. I 37.132 quamquam, quae verborum sententiarumque praecepta sunt, eadem ad sermonem pertinebunt. 133. Sed cum orationis indicem vocem habeamus, in voce autem duo sequamur, ut clara sit, ut suavis; “embora existam preceitos para as palavras e para as sentenças, eles pertencem ao discurso oratório. 133. Mas, como temos em nossa voz um indício, é na voz que devemos empregar outros dois preceitos: que ela seja clara, que seja suave”).

Cícero diz que o discurso acomodado às causas forenses, às assembleias e ao senado (contentiones) possui vigor diferente daquele acomodado às reuniões, às discussões, aos grupos de amigos e aos banquetes (sermones) (De Off. I 37,132 magna vis orationis est eaque duplex, altera contentionis, altera sermonis; “o vigor do discurso é, por si mesmo, duplo: um em relação ao debate 
público, outro em relação à conversação”). Quer dizer, a distinção entre sermo e contentio (ou disputatio) reside no vigor oratório (uis), que nas deliberações é máximo (Cíc. Or. 23,76; De or. I 60,255) e, no sermo, é remisso (Sên. Ep. Mor. 38 ad haec submissiora verba veniendum est; “devese recorrer a um vocabulário mais remisso”). Entretanto, o próprio Cícero acrescenta que os rétores tomaram conta da preceituação tanto de um gênero de discurso quanto do outro e que o sermo pode ter como matéria não só a doutrina, mas também os estudos, os assuntos domésticos e os assuntos da república (De Off. I 37,135 Habentur autem plerumque sermones aut de domesticis negotiis aut de re publica aut de artium studiis atque doctrina; “Conhecem-se, porém, muitos discursos sobre os assuntos particulares, sobre a república e sobre o método e o conhecimento técnicos”).

Assim é que as Ep. ad Caes. compartilham muito das características do discurso oratório e pouco da conversação ou antes, da espécie das epístolas. Primeiro, porque são preparadas e revestidas de aparato, i.e., o estilo delas é grave, o que se evidencia pelo uso de arcaísmos e de sententiae; segundo, na divisão das partes do discurso e na obediência às tarefas do orador, os documentos seguem as regras da arte da eloquência.

A classificação das Ep. ad Caes. como epístolas limita-se, portanto, à representação de um remetente e de um destinatário. Mais do que qualquer outra espécie de texto, a epístola é resultado de um jogo calculado de relações sociais, na medida em que uma das partes escolhe a apresentação de si e do que diz com base no tipo de relação que espera cultivar com a outra parte. No caso das Ep. ad Caes., esse jogo pressupõe não apenas a diferença entre o aconselhador e o aconselhado, mas ainda um “código de etiqueta” para o aconselhador dirigir-se a um superior - ainda que faltem a essas epístolas as formulae decorosas para o gênero. Se ainda as denomino de epístolas, entretanto, é por considerar o fato de que elas aproveitam elementos da espécie epistolar seuerum et graue tal como descrita por Cícero (Ad Att. 3. 11. 2; 5. 5. 1; 7. 5. 4-5); evidenciam a preocupação do emissor com a extensão do texto (Ep. ad Caes. I 8,7 quam paucissumis apsolui; “expus o mais brevemente possível; Ep. ad Caes. II 13,8 quam paucissumis potui perscripsi; “escrevi o mais brevemente que pude”) e cumprem a função parenética da epistolografia, porque se espera da epístola um brinde ao 
seu leitor, i.e., os preceitos do que se deve saber para bem viver (Cíc. Fam. 4.6.13; 6.10.6).

Parece claro, portanto, que a natureza de exercício das Ep. ad Caes. não faz delas nem um discurso de orador nem uma conversação nem uma epístola propriamente ditos, mas uma junção dos elementos de cada um deles no intuito de configurar uma peça de exibição de talento. Acrescento ainda que elas apresentam a divisão das partes do discurso de acordo com o gênero deliberativo, muito embora a disposição não seja objeto específico de preceituação pelos rétores no que se refere ao discurso de aparato ${ }^{144}$. Com efeito, esses documentos reforçam a afirmação de que os exercícios de formação do orador constituem um gênero próprio, a declamatio, distinto daqueles usados em situações reais quer pela inexistência do caso quer pela afetação da linguagem, a qual não se acha entre os elementos legítimos do discurso deliberativo (Quint. Inst. Or. III 8, 62 et seq.; Schwartz, 2000, pp. 273-278).

As Ep. ad Caes. somam os elementos do sermo e da disputatio por possuírem como matéria os assuntos da república - tratados ademais em estilo elevado e dispostos nas partes do discurso conforme os officia oratoris - mas destinarem-se a uma audiência que não deve ser necessariamente persuadida, e sim reconhecer o talento do orador pelos argumentos que utiliza ao imitar Salústio aconselhando César ${ }^{145}$. Isso porque a edificação da auctoritas do orador no discurso, o uso de arcaísmos e de sententiae servem como indício, nas Ep. ad Caes., da imitação de Salústio. Utilizado como modelo, esse historiador pode trazer a excelência desejada ao oferecer glória ao talento do orador e reter a memória dos eventos para as futuras gerações, evitando o tédio graças ao uso de palavras arcaicas e de figuras mais livres (Quint. Inst. Or. X 31 et seq). Embora a influência de Salústio em relação à elocução seja parcial, a imitação do referido historiador define um espectro de figuras adequadas ao discurso, além de dispor ao orador qual matéria serve para a situação da

144 cp. Fairwhether, 1981, pp. 190-97; Costrino, 2010, p. 37; q.v. Sen. Contr. I. 21; I 2,23; II, 1; II, 2; IV. 7; VII 6,21; IX. 25; I 2,23; Suas. II. 13; Quint. Inst. Or. VIII 3,22; Quint. Decl. 270, 9 et sane asperiores in controversia partes fortasse recti declamatoris relinquant. 10. divisio paene hoc proprium habet, ostendere ossa et nervos controversiae: et, secundum meum quidem iudicium, idem praestare declamatio debet.

145 Sobre a natureza dessa audiência, vide Schwartz, 2000, pp. 276-277. 
iminência de um conflito civil ${ }^{146}$. Para tanto, os documentos recuperam artisticamente as virtudes do príncipe a partir dos tópicos da causa útil e honesta. Ademais, à medida que vão sendo enumeradas, essas virtudes estabelecem a credibilidade do discurso, de tal maneira que o conselho do orador seja válido para aqueles que as reconheçam como virtudes do homem público. Nesse sentido, as Ep. ad Caes. não valem para persuadir sobre um problema real, porque seu tema é fictício. Quer dizer, por constituir-se discurso de personagem, elas servem para demonstrar a habilidade do orador (cp. Costrino, 2010, p. 39).

Pelo exposto, é possível dizer que as duas Ep. ad Caes. caracterizam-se menos pelo gênero de discurso ao qual estão identificadas, e mais por um expediente retórico particular - a prosopopeia -, que é essencial para a sua construção. Por causa disso, o autor, o discurso e o destinatário são convencionalmente ficcionais. Outros exemplos disso são numerosos, indo desde pequenos monólogos nas obras filosóficas (por ex. Sen. De ira I 3, 1-2; De Clem. I 1,2), nas próprias Ep. ad Caes. (II 13, 1-3), os discursos das figuras históricas reconstruídos pelos historiadores em suas monografias (por ex. Sal. Bel. Cat. 51.1-43), excursos poéticos (por ex. Luc. Bel. C. I 190-193) até mesmo obras inteiras (por ex. as Heroides ovidianas).

Em latim, a preceituação da prosopopeia (ou etopeia, ou fictio personae, ou allocutio, ou sermocinatio) aparece já na Retórica a Herênio (IV 52, 65 sermocinatio est, cum alicui personae sermo attribuitur et is exponitur cum ratione dignitatis), sendo depois retomada por Quintiliano como figura $^{147}$. Já Prisciano, devedor de Hermógenes, inclui a prosopopeia entre os exercícios do orador (Praex. 9, allocutio est imitatio sermonis ad mores et suppositas personas accomodata; “a prosopopeia é a imitação do discurso, acomodada ao caráter e à imitação das pessoas”), o que

146 cp. Ep. ad Caes. I 3.2-4; 4.1; 5.1-2; 7.4-5; 8.2; II 1.3; 2.1; II 8.3; 10.2-5; 12.7; Sal. Bel. Cat., 1, 3; 2, 3; 2, 5; 2,7-8; 3, 3; 4, 1; 5, 6; 9, 1-2; 11, 1-5; 12, 4-5; 13, 2-5; 19, 5; 20, 7-8; 51, 15; Bel. Iug., 1, 3-4; 2, 1-4; 19, 8; Ep. ad Caes. II 1.3-4 = Bel. Cat. 3,3 e 4,1; Ep. ad Caes. I 8.2 = Bel. Cat. 2,7-9; Ep. ad Caes. I 4.1 e II 4.1 = Bel. Cat. 5,6; Ep. ad Caes. II 5.3-5 = Bel. Cat. 9, 1-2, 11,1-5, 12,4-5; Ep. ad Caes. I 6.4 e 7,4-5 = Bel. Cat. 13, 2-5 e 14,7 e Ep. ad Caes. I 3.2-4 = Bel. Cat. 15,1.

147 Inst. Or. IX 2,29-30 Illa adhuc audaciora et maiorum, ut Cicero existimat, laterum, fictiones personarum, quae prosopopoiiai dicuntur: mire namque cum variant orationem tum excitant [...] et suadendo, obiurgando, querendo, laudando, miserando personas idoneas damus; IX 2,58 Imitatio morum alienorum, quae ethopoiia vel, ut alii malunt, mimesis dicitur, iam inter leniores adfectus numerari potest: est enim posita fere in eludendo. Sed versatur et in factis et in dictis. 
evidencia a multiplicidade de definições para esse expediente. A prosopopeia pode ser dialógica, não-dialógica ou monológica (Prisc. Praex. 9), correspondendo, respectivamente, àquilo que a personagem diz para outrem diante dele, àquilo que ela diz para outrem sem estar em sua presença ou àquilo que diz para si mesma. Nela, o orador deve refletir sobre o caráter próprio daquele que fala e qual é o caráter daquele a quem o discurso é dirigido, a ocasião, a circunstância, o lugar, os temas sobre os quais versa e o estilo a ser utilizado (cp. Teão Prog. 115.11.8 - 116.11.12).

Quanto à prosopopeia, não apenas Teão (Prog. 115.11.8) como ainda Quintiliano (Inst. Or. III 8, 49 et seq.) admitem que sua execução se dá preferencialmente por escrito, e Teão chega mesmo a preceituar o gênero e a espécie dela, i.e., sugerir que a prosopopeia seja integrada ao discurso demonstrativo, ao gênero deliberativo ou à espécie das epístolas. Quintiliano, por sua vez, sugere que a prosopopeia seja integrada ao gênero deliberativo pela importância que assume não apenas para o orador, como também ao poeta e ao historiador, já que acomoda as palavras à posição e ao caráter da audiência. O discurso deve privilegiar temas tanto poéticos quanto históricos a fim de elevar a matéria e a expressão.

Em todo caso, as Ep. ad Caes., pertencentes ao gênero das declamações porque são discurso de personagem, configuram-se como uma imagem da eloquência deliberativa semelhante à verdade (Quint. Inst. Or. II 10, 12 quare declamatio, quoniam est iudiciorum consiliorumque imago, similis esse debet veritati; "uma vez que a declamação, por ser a imagem dos julgamentos e dos aconselhamentos, deve ser semelhante à verdade”), compostas em linguagem ornada a fim de deleitar uma audiência ${ }^{148}$. Decerto, a verossimilhança com que a matéria foi tratada, no que se refere ao perigo de uma guerra civil, contribuiu para a negação, durante décadas, de sua artificialidade. Perfazendo uma longa lista das virtudes do príncipe e orientando-o moralmente a agir pelo bem de todos, entretanto, as epístolas mostram-se fiéis aos princípios que caracterizam o orador como uir bonus dicendi peritus. Dessa forma, demonstram tanto uma educação oratória

148 cp. Quint. Inst. Or. II 10, 10 Si uero in ostentationem comparetur declamatio, sane paulum aliquid inclinare ad uoluptatem audientium debemus. 11. Nam et iis actionibus quae in aliqua sine dubio ueritate uersantur, sed sunt ad popularem aptatae delectationem [...] permittitur adhibere plus cultus, omnemque artem, quae latere plerumque in iudiciis debet, non confiteri modo sed ostentare. 
adequada quanto um estudo diligente das virtudes do homem público, numa forma tal que essas sirvam, mais do que ilustrar a educação oratória, para orientá-la; ou seja, a imitação e o exercício não precederam a arte: antes a arte precedeu-os a eles. 


\section{Parte II}

\section{Texto original e tradução das Epistulae ad Caesarem ${ }^{149}$}

par A. Ernout. Paris: Collection “Les Belles Lettres”, 1962. O texto nelas estabelecido segue o de Kurfess. 


\section{Epistula I}

I.1. Pro uero antea optinebat regna atque imperia fortunam dono dare, item alia quae per mortaleis auide cupiuntur, quia et apud indignos saepe erant quasi per libidinem data neque cuiquam incorrupta permanserant. 2. Sed res docuit id uerum esse quod in carminibus Appius ait, fabrum esse suae quemque fortunae, atque in te maxume, qui tantum alios praegressus es ut prius defessi sint homines laudando facta tua quam tu laude digna faciundo. 3. Ceterum ut fabricata, sic uirtute parta quam magna industria haberei decet, ne incuria deformentur aut conruant infirmata. 4. Nemo enim alteri imperium uolens concedit et, quamuis bonus atque clemens sit, qui plus potest tamen, quia malo esse licet, formeidatur. 5. Id eo euenit quia plerique rerum potentes peruorse consulunt, et eo se munitiores putant quo illei quibus imperitant nequiores fuere. 6. At contra id eniti decet, cum ipse bonus atque strenuus sis, uti quam optimis imperites, nam pessumus quisque asperrume rectorem patitur. 7. Sed tibi hoc grauius est quam ante te omnibus, armis parta componere, quod bellum aliorum pace mollius gessisti. 8. Ad hoc uictores praedam petunt, uicti ciues sunt. Inter has difficultates euadendum est tibi atque in posterum firmanda res publica, non armis modo neque aduorsum hostis, sed, quod multo multoque asperius est, pacis bonis artibus. 9. Ergo omnes magna mediocri sapientia res huc uocat, quae quisque optima potest, utei dicant. 10. Ac mihi sic uidetur: qualeicumque modo tu uictoriam composuereis, ita alia omnia futura.

II. 1. Sed iam, quo melius faciliusque constituas, paucis quae me animus monet accipe. 
2. Bellum tibi fuit, imperator, cum homine claro, magnis opibus, auido potentiae, maiore fortuna quam sapientia. Quem secuti sunt pauci per suam iniuriam tibi inimici, item quos adfinitas aut alia necessitudo traxit. 3. Nam particeps dominationis neque fuit quisquam neque, si pati potuisset, orbis terrarum bello concussus foret. 4. Cetera multitudo uolgi, more magis quam iudicio, post alius alium quasi prudentiorem secuti.

5. Per idem tempus maledictis ineiquorum occupandae rei publicae in spem adducti homines quibus omnia probro et luxuria polluta erant, concurrere in castra tua et aperte quieteis mortem rapinas, postremo omnia quae corruptus animus lubebat, minitari. 6. Ex queis magna pars, ubi neque creditum condonarei neque te ciuibus sicuti hostibus uti uident, defluxere; pauci resistere quibus maius otium in castris quam Romae futurum erat: tanta uis creditorum impendebat. 7. Sed ob easdem causas immane dictust quanti et quam multi mortales postea ad Pompeium discesserint, eoque per omne tempus belli quasi sacro atque inspoliato fano debitores usi.

III. 1. Igitur quoniam tibi uictori de bello atque pace agitandum est, hoc uti ciuiliter deponas, illa <ut> quam iustissima et diuturna sit, de te ipso primum, qui ea compositurus es, quid optimum factu sit existima. 2. Equidem ego cuncta imperia crudelia magis acerba quam diuturna arbitror, neque quemquam multis metuendum esse quin ad eum ex multis formido reccidat: eam uitam bellum aeternum et anceps gerere, quoniam neque aduersus neque ab tergo aut lateribus tutus sis, semper in periculo aut metu agites. 3. Contra qui benignitate et clementia imperium temperauere, iis laeta et candida omnia uisa, etiam hostes aequiores quam aliis ciues. 4. Haud scio an me his dictis corruptorem uictoriae tuae nimisque in uictos bona uoluntate praedicent: scilicet quod ea, quae externis nationibus natura nobis hostibus nosque maioresque nostri saepe tribuere, ea ciuibus danda arbitror, neque barbaro ritu caede caedem et sanguinem sanguine expianda.

IV. 1. An illa, quae paulo ante hoc bellum in Cn. Pompeium uictoriamque Sullanam increpabantur, obliuio intercepit: Domitium, Carbonem, Brutum, alios item, non armatos 
neque in proelio belli iure sed postea supplices, per summum scelus interfectos, plebem Romanam in uilla publica pecoris modo conscissam? 2. Eheu! quam illa occulta ciuium funera et repentinae caedes, in parentum aut liberorum sinum fuga mulierum et puerorum, uastatio domuum, ante partam a te uictoriam omnia saeua atque crudelia erant! 3. Ad quae te illi idem hortantur: [et] scilicet id certatum esse, utrius uestrum arbitrio iniuriae fierent, neque receptam sed captam a te rem publicam, et ea causa exercitus stipendiis confectis optimos et ueterrimos omnium aduorsum fratres parentisque [alii liberos] armis contendere: ut ex alienis malis deterrumi mortales uentri atque profundae lubidini sumptus quarerent atque essent obprobria uictoriae, quorum flagitiis commacularetur bonorum laus. 4. Neque enim te praeterire puto quali quisque eorum more aut modestia etiam tum dubia uictoria sese gesserit, quoque modo in belli administratione scorta aut conuiuia exercuerint nonnulli, quorum aetas ne per otium quidem tales uoluptates sine dedecore attingerit.

V. 1. De bello satis dictum. De pace firmanda quoniam tuque et omnes tui agitatis, primum id, quaeso, considera quale sit de quo consultas: ita bonis malisque dimotis patenti uia ad uerum perges. 2. Ego sic existimo: quoniam orta omnia intereunt, qua tempestate urbi Romanae fatum excidii aduentarit, ciues cum ciuibus manus conserturos, ita defessos et exsangues regi aut nationi praedae futuros. Aliter non orbis terrarum neque cunctae gentes conglobatae mouere aut contundere queunt hoc imperium. 3. Firmanda igitur sunt $\varangle$ el $>$ concordiae bona et discordiae mala expellenda. 4. Id ita eueniet si sumptuum et rapinarum licentiam dempseris, non ad uetera instituta reuocans, quae iam pridem corruptis moribus ludibrio sunt, sed si suam quoique rem familiarem finem sumptuum statueris; 5. quoniam is incessit mos ut homines adulescentuli sua atque aliena consumere, nihil libidinei atque aliis rogantibus denegare pulcherrimum putent, eam uirtutem et magnitudinem animi, pudorem atque modestiam pro socordia aestiment. 6 . Ergo animus ferox praua uia ingressus, ubi consueta non suppetunt, fertur accensus in 
socios modo, modo in ciues, mouet composita et res nouas ueteribus + aec + conquirit. 7 . Quare tollendus est fenerator in posterum, uti suas quisque res curemus. 8. Ea uera atque simplex uia est, magistratum populo, non creditori gerere et magnitudinem animi in addendo, non demendo rei publicae ostendere.

VI. 1. Atque ego scio quam aspera haec res in principio futura sit, praesertim iis qui se in uictoria licentius liberiusque quam arctius futuros credebant. quorum si saluti potius quam lubidini consules, illosque nosque et socios in pace firma constitues; sin eadem studia artesque iuuentuti erunt, ne ista egregia tua fama simul cum urbe Roma breui concidet. 2. Postremo sapientes pacis causa bellum gerunt, laborem spe otii sustentant: nisi illam firmam efficis, uinci an uicisse quid retulit? 3. quare capesse, per deos, rem publicam et omnia aspera, uti soles, peruade: namque aut tu mederi potes, aut omittenda est cura omnibus. 4. Neque quisquam te ad crudeles poenas aut acerba iudicia inuocat, quibus ciuitas uastatur magis quam corrigitur, sed ut prauas artis malasque libidines ab iuuentute prohibeas. 5. Ea uera clementia erit consuluisse ne immerito ciues patria expellerentur, retinuisse ab stultitia et falsis uoluptatibus, pacem concordiamque stabiliuisse, non si flagitiis opsecutus, delicta perpessus, praesens gaudium quom mox futuro malo concesseris.

VII. 1. Ac mihi animus, quibus rebus alii timent, maxume fretus est: negotii magnitudine et quia tibi terrae et maria simul omnia componenda sunt. Quippe res paruas tantum ingenium attingere nequeiret, magnae curae magna merces est. 2. Igitur prouideas oportet uti pleps, largitionibus et publico frumento corrupta, habeat negotia sua quibus ab malo publico detineatur: iuuentus probitati et industriae, non sumptibus neque diuitiis studeat. 3. Id ita eueniet, si pecuniae, quae maxuma omnium pernicies est, usum atque decus dempseris. 4. Nam saepe ego quom animo meo reputans quibus quisque rebus clari uiri magnitudinem inuenissent, quaeque res populos nationesue magnis auctibus auxissent ac deinde quibus causis amplissima regna et imperia conruissent, eadem semper 
bona atque mala reperiebam, omnesque uictores diuitias contempsisse et uictos cupiuisse. 5. Neque aliter quisquam extollere sese et diuina mortalis attingere potest, nisi omissis pecuniae et corporis gaudiis, animo indulgens, non adsentando neque concupita praebendo peruorsam gratiam gratificans, sed in labore, patientia, bonisque praeceptis et factis fortibus exercitando.

VIII. 1. Nam domum aut uillam exstruere, eamque signis, aulaeis aleisque operibus exornare, et omnia potius quam semet uisendum efficere, id est non diuitias decori habere, sed ipsum illis flagitio esse. 2. Porro ei quibus bis die uentrem onerare, nullam noctem sine scorto quiescere mos est, ubi animum, quem dominari decebat, seruitio oppressere, nequeicquam eo postea hebeti atque claudo pro exercito uti uolunt: nam inprudentia pleraque et se praecipitat. 3 . Verum haec et omnia mala pariter cum honore pecuniae desinent, si neque magistratus neque alia uolgo cupienda uenalia erunt.

4. Ad hoc prouidendum est tibi quonam modo Italia atque prouinciae tutiores sint: id quod factu haut obscurum est. 5. Nam idem omnia uastant suas deserendo domos et per iniuriam alienas occupando. 6. Item ne, uti adhuc, militia iniusta aut inaequalis sit, cum alii triginta, pars nullum stipendium faciunt. Et frumentum id, quod antea praemium ignauiae fuit, per municipia et colonias illis dare conueniet qui stipendiis emeritis domos reuerterint.

7. Quae rei publicae necessaria tibique gloriosa ratus sum, quam paucissumis apsolui. 8. Non peius uidetur pauca nunc de facto meo disserere. 9. Plerique mortales ad iudicandum satis ingenii habent aut simulant. Verum enim ad reprehendunda aliena facta aut dicta ardet omnibus animus, uix satis apertum os aut lingua prompta uidetur quae meditata pectore euoluat. Quibus me subiectum haud paenitet, magis reticuisse pigeret. 10. Nam, siue hac, seu meliore alia uia perges, a me quidem pro uirili parte dictum et adiutum fuerit. Relicuum est optare uti quae tibi placuerint, ea di immortales adprobent beneque euenire sinant. 


\section{Epistula II}

I. 1. Scio ego quam difficile atque asperum factu sit consilium dare regi aut imperatori postremo quoiquam mortali quoius opes in excelso sunt, quippe cum et illis consultorum copiae adsint, neque de futuro quisquam satis callidus satisque prudens sit. 2 . Quin etiam saepe praua magis quam bona consilia prospere eueniunt, quia plerasque res fortuna ex libidine sua agitat. 3. Sed mihi studium fuit adulescentulo rem publicam capessere, atque in ea cognoscenda multam magnamque curam habui; non ita, ut magistratum modo caperem, quem multi malis artibus adepti erant, sed etiam ut rem publicam domi militiaeque quantumque armis, uiris, opulentia posset, cognitum habuerim. 4. Itaque mihi multa cum animo agitanti consilium fuit famam modestiamque meam post tuam dignitatem haberei et quoius rei lubet periculum facere, dum quid tibi ex eo gloriae acciderit. 5. Idque non temere neque ex fortuna tua decreui, sed quia in te praeter ceteras artem unam egregie mirabilem comperi: semper tibi maiorem in aduersis, quam in secundis rebus animum esse. 6 . Sed per ceteros mortalis illa res clarior est, quod prius defessi sint homines laudando atque admirando munificentiam tuam, quam tu [in] faciundo quae gloria digna essent.

II. 1. Equidem mihi decretum est nihil tam ex alto reperiri posse, quod non cogitanti tibi in promptu sit. 2. Neque eo quae uisa sunt de re publica tibi scripsi quia mihi consilium atque ingenium meum amplius aequo probaretur, sed inter labores militiae interque proelia, uictorias, imperium, statui admonendum te de negotiis urbanis. 3. Namque tibi si id modo in pectore consilii est ut te ab inimicorum impetu uindices, quoque modo contra aduersum consulem beneficia populi retineas, indigna uirtute tua cogites. 4 . 
Sin in te ille animus est qui iam a principio nobilitatis factionem disturbauit, plebem Romanam ex graui seruitute in libertatem restituit, in praetura inimicorum arma inermis disiecit, domi militiaeque tanta et tam praeclara facinora fecit ut ne inimici quidem queri quicquam audeant nisi de magnitudine tua: quin tu accipe ea quae dicam de summa republica. Quae profecto aut uera inuenies aut certe haud procul a uero.

III. 1. Sed quoniam Cn. Pompeius aut animi prauitate aut quia nihil eo maluit quod tibi obesset, ita lapsus est ut hostibus tela in manus iaceret quibus ille rebus rem publicam conturbauit, eisdem tibi restituendum est. 2. Primum omnium summam potestatem moderandi de uectigalibus, sumptibus, iudiciis senatoribus paucis tradidit, plebem Romanam, quoius antea summa potestas erat, ne aequeis quidem legibus in seruitute reliquit. 3. Iudicia tametsi, sicut antea, tribus ordinibus tradita sunt, tamen idem illi factiosi regunt, dant, adimunt quae lubet, innocentis circumueniunt, suos ad honorem extollunt; 4. Non facinus, non probrum aut flagitium obstat quo minus magistratus capiant. Quod commodum est trahunt, rapiunt; postremo, tanquam urbe capta, libidine ac licentia sua pro legibus utuntur. 5. Ac me quidem mediocris dolor angeret, si uirtute partam uictoriam more suo per seruitium exercerent. 6. Sed homines inertissimi, quorum omnis uis uirtusque in lingua sita est, forte atque alterius socordia dominationem oblatam insolentes agitant. 7. Nam quae seditio aut dissensio ciuilis tot tam inlustres familias ab stirpe euertit? Aut quorum unquam in uictoria animus tam praeceps tamque immoderatus fuit?

IV. 1. L. Sulla, cui omnia in uictoria lege belli licuerunt, tametsi supplicio hostium partes suas muniri intellegebat tamen paucis interfectis ceteros beneficio quam metu retinere maluit. 2. At hercule M. Catoni L. Domitio ceterisque eiusdem factionis quadraginta senatores, multi praeterea cum spe bona adolescentes sicutei hostiae mactati sunt, quom interea inportunissima genera hominum tot miserorum ciuium sanguine satiari nequierunt: non orbi liberi, non parentes exacta aetate, non luctus gemitus uirorum, 
mulierum, immanem eorum animum inflexit quein acerbius in dies male faciundo ac dicundo dignitate alios alios, ciuitate euersum irent. 3. Nam quid ego de te dicam? Cuius contumeliam homines ignauissimi uita sua commutare uolunt, si liceat. Neque illis tantae uoluptati est, tametsi insperantibus accidit, dominatio quanto maerori tua dignitas: quein optatius habent ex tua calamitate periculum libertatis facere, quam per te populi Romani imperium maximum ex magno fieri. 4. Quo magis tibi etiam atque etiam animo prospiciendum est quonam modo rem stabilias communiasque. 5. Mihi quidem quae mens suppetit eloqui non dubitabo; ceterum tuei erit ingenii probare quae uera atque utilia factu putes.

V. 1. In duas partes ego ciuitatem diuisam arbitror, sicut a maioribus accepi, in patres et plebem. Antea in patribus summa auctoritas erat, uis multo maxuma in plebe. 2. Itaque saepius in ciuitate secessio fuit, semperque nobilitatis opes deminutae sunt et ius populi amplificatum. 3. Sed plebs eo libere agitabat quia nullius potentia super leges erat, neque diuitiis aut superbia sed bona fama factisque fortibus nobilis ignobilem anteibat: humillumus quisque in aruis aut in militia nullius honestae rei egens satis sibi satisque patriae erat. 4. Sed ubi eos paulatim expulsos agris inertia atque inopia incertas domos habere subegit, coepere alienas opes petere, libertatem suam cum re publica uenalem habere. 5. Ita paulatim populus qui dominus erat, et cunctis gentibus imperitabat, dilapsus est et pro communi imperio priuatim sibi quisque seruitutem peperit. 6. Haec igitur multitudo primum malis moribus inbuta, deinde in artis uitasque uarias dispalata, nullo modo inter se congruens, parum mihi quidem idonea uidetur ad capessendam rem publicam. 7. Ceterum additis nouis ciuibus magna me spes tenet fore ut omnes expergiscantur ad libertatem, quippe cum illis libertatis retinendae, tum his seruitutis amittendae cura orietur. 8. Hos ego censeo permixtos cum ueteribus nouos in coloniis constituas: ita et res militaris opulentior erit et plebs bonis negotiis impedita malum publicum facere desinet. 
VI. 1. Sed non inscius neque imprudens sum, quom ea res agetur, quae saeuitia quaeque tempestates hominum nobilium futurae sint, quom indignabuntur omnia funditus misceri antiquis ciuibus hanc seruitutem imponi, regnum denique ex libera ciuitate futurum, ubi unius munere multitudo ingens in ciuitatem peruenerit. 2. Equidem ego sic apud animum meum statuo: malum facinus in se admittere qui incommodo rei publicae gratiam sibi conciliet; ubi bonum publicum etiam priuatim usui est, id uero dubitare adgredi socordiae atque ignauiae duco. 3. M. Druso semper consilium fuit in tribunatu summa ope niti pro nobilitate; neque ullam rem in principio agere intendit, nisi illei auctores fuerant. 4. Sed homines factiosi, quibus dolus atque malitia fide cariora erant, ubi intellexerunt per unum hominem maxumum beneficium multis mortalibus dari, uidelicet sibi quisque conscius malo atque infido animo esse, de M. Druso iuxta, ac se existumauerunt. 5. Itaque metu ne per tantam gratiam solus rerum poteretur, contra eam nisi, sua ipseius consilia disturbauerunt. 6. Quo tibi, imperator, maiore cura fideque amici et multa praesidia paranda sunt.

VII. 1. Hostem aduersum deprimere strenuo homini haud difficilest; occulta pericula neque facere neque uitare bonis in promtu est. 2. Igitur, ubi eos in ciuitatem adduxeris, quoniam quidem reuocata plebs erit, in ea re maxume animum excerceto ut colantur boni mores, concordia inter ueteres et nouos coalescat. 3. Sed multo maxumum bonum patriae, ciuibus, tibi, liberis, postremo humanae genti pepereris, si studium pecuniae aut sustuleris aut, quoad res feret, minueris. Aliter neque priuata res neque publica neque domi neque militiae regi potest. 4 . Nam ubi cupido diuitiarum inuasit neque disciplina neque artes bonae neque ingenium ullum satis pollet quin animus, magis aut minus mature, postremo tamen, subcumbat. 5. Saepe iam audiui qui reges quae ciuitates et nationes per opulentiam magna imperia amiserint quae per uirtutem inopes ceperant. Id adeo haud mirandum est. 6. Nam ubi bonus deteriorem diuitiis magis clarum, magisque acceptum uidet, primo aestuat multaque in pectore uoluit; sed ubi gloria, honorem magis 
in dies uirtutem opulentia uincit animus ad uoluptatem a uero deficit. 7. Quippe gloria industria alitur: ubi eam dempseris, ipsa per se uirtus amara atque aspera est. 8. Postremo ubi diuitiae clarae habentur, ibi omnia bona uilia sunt, fides, probitas, pudor, pudicitia. 9. Nam ad uirtutem una et ardua uia est, ad pecuniam qua quique lubet nititur: et malis et bonis rebus ea creatur. 10. Ergo in primis auctoritatem pecuniae demito. Neque de capite neque de honore ex copiis quisquam magis aut minus iudicauerit, sicut neque praetor neque consul ex opulentia, uerum ex dignitate creetur. 11. Sed de magistratu facile populi iudicium fit: iudices a paucis probari regnum est, ex pecunia legi inhonestum. Quare omnes primae classis iudicare placet, sed numero plures quam iudicant. 12. Neque Rhodios neque alias ciuitates unquam iudiciorum suorum paenituit, ubi promiscue diues et pauper, ut cuique fors tulit, de maxumis rebus iuxta ac de minumis disceptat.

VIII. 1. Sed de magistratibus creandis haud mihi quidem apsurde placet lex quam C. Gracchus in tribunatu promulgauerat, ut ex confusis quinque classibus sorte centuriae uocarentur. 2. Ita coaequata dignitate, pecunia, uirtute anteire alius alium properabit. 3. Haec magna remedia contra diuitias statuo. Nam perinde omnes res laudantur atque adpetuntur ut earum rerum usus est. Malitia praemiis excercetur: ubi ea dempseris, nemo omnium gratuito malus est. 4. Ceterum auaritia belua fera, immanis, intoleranda est; quo intendit, oppida, agros fana atque domos uastat, diuina cum humanis permiscet, neque exercitus neque moenia obstant quominus ui sua penetret; fama, pudicitia, liberis, patria, atque parentibus cunctos mortales spoliat. 5. Verum, si pecuniae decus ademeris, magna illa uis auaritiae facile bonis moribus uincetur. 6 . Atque haec ita sese habere tametsi omnes aequi atque iniqui memorent, tamen tibi cum factione nobilitatis haud mediocriter certandum est. Quoius si dolum caueris, alia omnia in procliui erunt. 7. Nam ii, si uirtute satis ualerent, magis aemuli bonorum quam inuidi essent. Quia desidia et inertia, stupor eos atque torpedo inuasit, strepunt, obtrectant, alienam famam bonam suum dedecus aestumant. 
IX. 1. Sed, quid ego plura quasi de ignotis memorem? M. Bibuli fortitudo atque animi uis in consulatum erupit; hebes lingua, magis malus quam callidus ingenio: quid ille audeat, quoi consulatus, maximum imperium, maxumo dedecori fuit? 2. An L. Domiti magna uis est, quoius nullum membrum a flagitio aut facinore uacat? lingua uana, manus cruentae, pedes fugaces; quae honeste nominari nequeunt, inhonestissima. 3. Vnius tamen M. Catonis ingenium uersutum, loquax, callidum haud contemno. Parantur haec disciplina Graecorum. Sed uirtus, uigilantia, labor apud Graecos nulla sunt: quippe qui domi libertatem suam per inertiam amiserint, censesne eorum praeceptis imperium haberi posse? 4. Reliqui de factione sunt inertissumi nobiles, in quibus sicut in titulo praeter bonum nomen nihil est additamenti. L. Postumii M. Fauonii mihi uidentur quasi magnae nauis superuacua onera esse: ubi salui peruenere, usui sunt; si quid aduersi coortum est, de illeis potissumum iactura fit, quia pretii minimi sunt.

X. 1. Nunc quoniam, sicut mihi uideor, de plebe renouanda corrigendaque satis disserui, de senatu quae tibi agenda uidentur, dicam. 2. Postquam mihi aetas ingeniumque adoleuit, haud ferme armis atque equis corpus exercui, sed animum in litteris agitaui; quod natura firmius erat, id in laboribus habui. 3. Atque ego in ea uita multa legendo atque audiendo ita comperi omnia regna, item ciuitates et nationes usque eo prosperum imperium habuisse dum apud eos uera consilia ualuerunt: ubicumque gratia, timor, uoluptas ea corrupere, post paulo imminutae opes, deinde ademtum imperium, postremo seruitus imposita est. 4. Equidem ego sic apud animum meum statuo: cuicumque in sua ciuitate amplior inlustriorque locus quam aliis est, ei magnam curam esse rei publicae. 5. Nam ceteris salua urbe tantum modo libertas tuta est: qui per uirtutem sibi diuitias, decus, honorem pepererunt, ubi paulum inclinata res publica agitari coepit, multipliciter animus curis atque laboribus fatigatur: aut gloriam, aut libertatem, aut rem familiarem defensat, omnibus locis adest, festinat; quanto in secundis rebus florentior fuit, tanto in aduorsis asperius magisque anxie agitat. 6. Igitur, ubi plebes senatui sicuti corpus animo oboedit 
eiusque consulta exsequitur, patres consilio ualere decet, populo superuacuanea est calliditas. 7. Itaque maiores nostri, cum bellis asperrumis premerentur, equis, uiris, pecunia amissa, nunquam defessi sunt armati de imperio certare. Non inopia aerarii, non uis hostium, non aduersa res ingentem eorum animum subegit quin, quae uirtute ceperant, simul cum anima retinerent. 8. Atque ea magis fortibus consiliis quam bonis proeliis patrata sunt. Quippe apud illos una res publica erat, ei omnes consulebant, factio contra hostes parabatur, corpus atque ingenium patriae, non suae quisque potentiae exercitabat. 9. At hoc tempore contra ea homines nobiles, quorum animos socordia atque ignauia inuasit, ignarei laboris, hostium, militiae, domi factione instructi, per superbiam cunctis gentibus moderantur.

XI. 1. Itaque patres, quorum consilio antea dubia res publica stabiliebatur, oppressi ex aliena libidine huc atque illuc fluctuantes agitantur: interdum alia, deinde alia decernunt; uti eorum qui dominantur simultas aut gratia fert, ita bonum malumque publicum aestumant. 2. Quodsi aut libertas aequa omnium, aut sententia obscurior esset, maioribus opibus res publica et minus potens nobilitas esset. 3. Sed quoniam coaequari gratiam omnium difficile est, quippe cum illis maiorum uirtus partam reliquerit gloriam, dignitatem, clientelas, cetera multitudo pleraque insititia sit, sententia eorum a metu libera: ita in occulto sibi quisque alterius potentia carior erit. 4. Libertas iuxta bonis et malis, strenuis et ignauis optabilis est; uerum eam plerique metu deserunt, stultissumi mortales: quod in certamine dubium est quorsum accidat, id per inertiam in se quasi uicti recipiunt. 5. Igitur duabus rebus confirmari posse senatum puto: si numero auctus per tabellam sententiam feret. Tabella obtentui erit, quo magis animo libero facere audeat: in multitudine et praesidii plus et usus amplior est. 6. Nam fere his tempestatibus, alii iudiciis publicis, alii priuatis suis atque amicorum negotiis implicati, haud sane rei publicae consiliis adfuerunt. Neque eos magis occupatio quam superba imperia distinuerunt; homines nobiles cum paucis senatoris quos additamenta factionis habent, quaecumque 
libuit probare, reprehendere, decernere, ea, uti lubido tulit, fecere. 7. Verum ubi numero senatorum aucto per tabellam sententiae dicentur, ne illi superbiam suam dimittent, ubi iis oboediendum erit quibus antea crudelissume impertitabant.

XII. 1. Forsitan, imperator, perfectis litteris desideres quem numerum senatorum fieri placeat, quoque modo is in multa $<e t>$ uaria officia distribuatur; iudicia quoniam omnibus primae classis committenda putem, quae descriptio, quei numerus in quoque genere futurus sit. 2. Ea mihi omnia generatim describere haud difficile factu fuit, sed prius laborandum uisum est de summa consilii, idque tibi probandum uerum esse. Si hoc itinere uti decreueris, cetera in promtu erunt. 3. Volo ego consilium meum prudens maxumeque usui esse. Nam ubicumque tibi res prospere cedet, ibi mihi bona fama eueniet. 4. Sed me illa magis cupido exercet, ut quocumque modo quam primum res publica adiutetur. 5. Libertatem gloria cariorem habeo. Atque ego te oro hortorque ne clarissimus imperator, Gallica gente subacta, populi Romani summum atque inuictum imperium tabescere uetustate ac per summam discordiam dilabi patiaris. 6. Profecto, si id accidat, neque tibi nox neque dies curam animi sedauerit, quin insomniis exercitus, furibundus atque amens alienata mente feraris. 7. Namque mihi pro uero constat omnium mortalium uitam diuino numine inuisier; neque bonum neque malum facinus quoiusquam pro nihilo haberi, sed ex natura diuorsa praemia bonos malosque sequi. 8. Interea si forte ea tardius procedunt, suus quoique animus ex conscientia spem praebet.

XIII. 1. Quodsi tecum patria atque parentes possent loqui, scilicet haec tibi dicerent: O Caesar, nos te genuimos fortissimi uiri, in optima urbe, decus praesidiumque nobis, hostibus terrorem. 2. Quae multis laboribus et periculis ceperamus, ea tibi nascenti cum anima simul tradidimus: patriam maxumam in terris, domum familiamque in patria clarissimam, praeterea bonas artis, honestas diuitias, postremo omnia honestamenta pacis et praemia belli. 3. Pro his amplissimis beneficiis non flagitium a te neque malum facinus, petimus, sed utei libertatem euersam restituas. 4. Qua re patrata, profecto per gentes 
omnes fama uirtutis tuae uolitabit. 5. Namque hac tempestate, tametsi domi militiaeque praeclara facinora egisti, tamen gloria tua cum multis uiris fortibus aequalis est; si uero urbem amplissimo nomine ex maxumo imperio prope iam ab occasu restitueris, quis te clarior, quis maior in terris fuerit? 6. Quippe si morbo iam aut fato huic imperio secus accidat, cui dubium est quin per orbem terrarum uastitas, bella, caedes, oriantur? Quodsi tibi bona lubido fuerit patriae parentibus gratificandi, postero tempore, re publica restituta super omnis mortales gloria agitabis, tuaque unius mors uita clarior erit. 7. Nam uiuos interdum fortuna, saepe inuidia fatigat: ubi anima naturae cessit, demptis obtrectationibus, ipsa se uirtus magis magisque extollit.

8. Quae mihi utilissima factu uisa sunt quaeque tibi usui fore credidi, quam paucissumis potui perscripsi. Ceterum deos immortalis optestor ut, quocumque modo ages, ea res tibi reique publicae prospere eueniat. 


\section{Epístola I}

I. 1. Tinha-se antes por verdade que a fortuna dava os reinos e os impérios como um presente, assim como outros bens avidamente almejados pelos mortais, não só porque tinham sido muitas vezes concedidos aos indignos quase por capricho, como também não permaneceriam a salvo nas mãos de ninguém. 2. Mas a prática ensinou que é verdade aquilo que Ápio diz em seu poema: “cada um é artífice de sua própria sorte”; principalmente no que diz respeito a ti, pois foste tão mais longe do que os demais, que antes os homens se cansariam celebrando teus feitos do que tu, empreendendo feitos dignos de celebração. 3. Tal como uma construção, aquilo que se obtém pela virtude deve ser mantido com enorme esforço, para não se deformar pela incúria ou desmoronar pela infirmeza. 4. De fato, não há quem conceda de livre e espontânea vontade seu poder a outrem e, embora seja bondoso e clemente, quem pode muito é temido, todavia, porque lhe é permitido ser mau. 5. Disto sucede que muitos poderosos tomam decisões erradamente, e tanto mais fortes se julgam quanto mais fracos foram aqueles sobre os quais imperam. 6. Convém te esforçares no sentido oposto, sendo, tu mesmo, bom e diligente, para que governes os melhores, 6 . pois os piores homens suportam penosamente um chefe. 7. Mas para ti o que é mais difícil do que para todos os teus antecessores é isto: organizar o que obtiveste com armas. Foste mais direito na guerra do que outros, na paz. 8. Para isso os vencedores buscam a presa; os vencidos são cidadãos. Em meio a tais dificuldades deves também salvar e preparar a república para o futuro, não só com o apoio das armas ou com assaltos aos inimigos e sim - o que é muito e muito mais difícil - com as

vantagens da paz. 9. O momento pede que todos, de grande e pequena sabedoria, exponham a melhor opinião que tiverem. 10. No entanto me parece que, como quer que tenhas obtido a vitória, 
assim também o será em relação ao futuro.

II.1. Mas agora, para que melhor e mais facilmente decidas que caminho seguir, aceita em poucas palavras o que o ânimo me adverte.

2. Estiveste em conflito, imperador, contra um homem ilustre, de grande autoridade, ávido pelo poder, dotado de maior sorte do que esperteza, a quem seguiram uns poucos que se declararam inimigos teus por injúria, bem como aqueles a quem arrastou o parentesco ou alguma outra necessidade. 3. Não houve quem dividisse o poder com ele e, se não surgisse alguém que pudesse ser tolerado, o mundo não se abalaria com esta guerra. 4. Outro número de pessoas, mais por hábitos do vulgo do que por bom senso, seguiram uns aos outros como quem segue o mais prudente. 5. Ao mesmo tempo, homens manchados por toda a luxúria e torpeza avançaram contra teus acampamentos, levados pelas calúnias de infames na esperança de tomar o poder, e ameaçavam abertamente os inocentes com a morte, roubo e tudo enfim que agrade a um espírito corrompido. 6 . Grande parte desses, percebendo que tu não perdoavas as dívidas nem vias concidadãos como inimigos, desistiu; poucos preferiram resistir nos acampamentos a permanecer em Roma, tamanha era a soma que deviam aos credores. 7. Por essas mesmas razões, é espantoso dizer quais e quantos mortais passaram para o lado de Pompeu e como se serviram dele, durante toda a guerra, como de um templo sagrado e inviolável.

III. 1. Já que a ti, vencedor, caberá então dispor da paz e da guerra, resolve, para concluir essa como convém a um cidadão e fazer daquela a mais justa e duradoura, o que deve ser feito primeiro em relação a ti, porque tu o decidirás da melhor maneira possível. 2. Quanto a mim, julgo que todo o poder cruel é mais severo do que duradouro, e imagino que não haja alguém que a muitos assuste sem que de muitos tenha medo: viver desta maneira é duvidoso, é viver numa guerra eterna, porque jamais se está a salvo nem pela frente, nem pelas costas, nem pelos lados, estando sempre em perigo ou assustado. 3. Quem, ao contrário, abrandou o poder com benignidade e clemência, a esses tudo parece feliz e calmo, e mesmo os inimigos dão-lhes um tratamento mais 
justo do que os cidadãos a estrangeiros. 4. Sei que haverá quem diga que eu desmereço tua vitória com estas minhas palavras, e que sou demasiadamente generoso com os vencidos. Na verdade, aquilo que tanto nós quanto nossos antepassados concedemos aos povos estrangeiros, inimigos nossos por natureza, penso eu deve ser dado aos cidadãos, e não deve ser vingado, como no ritual bárbaro, a desgraça com a desgraça e o sangue com o sangue.

IV. 1. Por acaso caíram no esquecimento aqueles rumores que, antes da guerra, censuravam Cneu Pompeu e a vitória de Sula? Domício, Carbão, Bruto e outros tantos assassinados não pelo direito dado em uma guerra, mas sim depois, quando suplicavam pelo fim desta terribilíssima atrocidade? E a plebe romana abatida como gado no campo? 2. Oh, quão cruéis e desumanos foram, antes de tua vitória, os assassinatos de cidadãos às escondidas, a repentina mortandade, a fuga de mulheres e de crianças para o seio de seus pais e de seus filhos, os lares destruídos! 3. É a isso mesmo que eles te exortam; a questão é saber se as injustiças serão cometidas pelo arbítrio teu ou dele, e se a república não será aceita por ti, mas capturada; para esse fim, cumprido o serviço militar, os teus melhores e mais antigos soldados levantaram as armas contra os pais e os irmãos (outros contra os filhos): para que os mais vis mortais obtenham, pela desgraça alheia, os ganhos para sustentar o ventre e a insaciável luxúria, e sejam a desonra de uma vitória, maculando com seus delitos a integridade dos bons. 4. Eu julgo de fato que tu não ignoras como alguns deles se comportavam com modéstia no momento em que a vitória era incerta, e como nenhum conduziu as operações de guerra entre prostíbulos e festins; para eles, mesmo em tempo de paz entregar-se a tais prazeres seria uma desonra.

V. 1. Sobre a guerra foi dito o bastante. Quanto à afirmação da paz, preocupação tua e de todos os que te seguem, peço-te considerar inicialmente qual seja o objeto de tuas deliberações; assim, distintas as vantagens das desvantagens, caminharás por uma estrada livre rumo à verdade. 2 . Eu particularmente acredito que tudo o que nasce, morre, e que, neste tempo, a destruição se aproxima de Roma: os cidadãos lutarão contra cidadãos, e assim, extenuados e exangues, serão presa fácil de um rei ou de uma nação - de outra maneira nem o mundo inteiro nem todos os povos 
coligados seriam capazes de destruir ou abater este império. 3. Devem pois serem firmadas, acima de tudo, as vantagens da concórdia e repudiados os males da discórdia. 4. Isso ocorrerá se reprimires o excesso de luxo e de roubo, não reclamando as antigas instituições (que são, há muito tempo, por causa da corrupção dos costumes, alvo de escárnio), mas determinando a cada um o limite de despesas de acordo com seu patrimônio familiar, 5. muito embora tenha-se introduzido o costume de os jovens consumirem o que é seu e o que é alheio, e julguem extremamente belo não recusar o prazer próprio nem o que os outros lhe pedem. Isso eles julgam ser virtude e grandeza de espírito; o pudor e a modéstia julgam ser indolência. 6. É assim que um espírito feroz, ao entrar no mau caminho, sem que o satisfaça aquilo que costumava ter, vai de encontro ora aos aliados ora aos concidadãos, perturba a ordem, busca novas condições a débitos antigos. 7. Portanto, no futuro, deve-se exterminar a usura de maneira que cada um de nós cuide de nossos próprios interesses. 8. Eis a maneira mais simples e mais verdadeira para chegar a isto: que o magistrado sirva ao povo, não aos credores, e ostente a sua grandeza de espírito fazendo com que a república ganhe, não perca.

VI. 1. Sei como será difícil, a princípio, essa tarefa, especialmente àqueles que acreditavam obter com a vitória mais excesso e permissão do que restrições. Se te preocupares com a salvação deles em vez de seus desejos, assegurarás uma paz duradoura a eles, a nós e aos aliados. Porém, se a juventude mantiver este comportamento e estes artifícios, esta tua fama singular em breve cairá junto à própria Roma. 2. Por último, os sábios travam guerras em benefício da paz, suportam o cansaço na esperança do repouso. Se não fizeres da paz algo duradouro, de que te servirá vencer ou ser vencido? 3. Portanto ocupa-te - pelos deuses! - da república e, como é de teu costume, enfrenta até o fim todas as dificuldades, já que somente tu podes remediá-la, ou ninguém mais se atreverá a isso. 4. Não há ninguém que te peça seres cruel nos castigos ou rígido nos julgamentos, maneiras pelas quais a cidade não é reformada, mas destruída. Deves afastar da juventude as más condutas e os desejos perversos. A verdadeira clemência está nisto: ter impedido que os cidadãos sejam expulsos da cidade, mesmo se o merecessem; tê-los preservado da estupidez e dos falsos prazeres; 
ter estabelecido a paz e a concórdia e não ter sido condescendente com a ignomínia deles, não ter sofrido com seus delitos, concedendo no presente o que será no futuro um mal.

VII. 1. No que me diz respeito, meu espírito se apóia principalmente naquilo que outros temem: na grandeza da obra pela qual terras e mares serão por ti conquistados. Embora tamanha sagacidade não queira chegar a resultados modestos, grandes prêmios provêm de grandes cuidados. 2. Deves, portanto, tomar providências para que a plebe, corrompida pelas liberalidades e pela distribuição de alimento, faça seus negócios sem contribuir para a calamidade pública, e para que a juventude empregue seu vigor na integridade e naquilo que merece esforço, e não no dispêndio e nas dívidas. 3. Isso poderá acontecer se impedires o uso e o respeito ao dinheiro, que é a maior causa da desgraça dos homens. 4. Refletindo muitas vezes comigo mesmo sobre aquilo que pôde proporcionar glória aos homens ilustres e aumentar as riquezas de povos ou nações, e depois sobre as causas que destruíram impérios e reinos enormes, percebia que as causas da ventura e da ruína eram sempre as mesmas: todos os vencedores haviam desprezado as riquezas, enquanto os vencidos, haviam-nas desejado. 5. Não há outra maneira de o homem elevar-se e, sendo mortal, poder atingir o divino, a não ser renunciando ao dinheiro e aos prazeres do corpo, entregando-se ao cultivo de sua própria alma, sem assentir ou favorecer à ambição e satisfazer desejos ímprobos, mas ao exercitá-lo nas tarefas difíceis, na paciência, nos bons preceitos, nas belas ações.

VIII. 1. Com efeito, construir casas e fazendas, orná-las com estátuas, tapetes e outras obras de arte para chamar mais a atenção do que elas fazem por si mesmas não é ter riquezas por distinção, e sim tê-las por depravação. 2. Considero que aqueles que costumam encher o estômago duas vezes ao dia e não passar uma só noite sem a companhia de meretrizes, sendo assim escravos do espírito que deveriam dominar, mais tarde, tendo-o enfraquecido e vacilante, debalde quererão exercitá-lo. 3. Na verdade, é a imprudência que muitas vezes destrói a si mesma. Esse e todos os outros males, assim como a honra concedida ao dinheiro, acabariam se nem a magistratura nem outras coisas desejadas pelo vulgo fossem colocadas à venda. 4. Deves fazer com que a Itália e as províncias fiquem, de alguma maneira, livres de perturbações. E isto não é difícil de ser feito. 5. De 
fato, são sempre os mesmos que causam desgraças ao abandonar suas casas e ocupar outras ilicitamente. 6. Da mesma forma, deves fazer com que o serviço militar não seja injusto ou desigual, como tem sido até agora, quando alguns têm trinta anos de serviço prestado, enquanto outros sequer chegam a servir. O frumento, que foi dado outrora como um prêmio aos ignavos, convêm distribuilo pelos municípios e colônias àqueles que retornarem a seus lares tendo cumprido o tempo de serviço militar.

7. Sobre aquilo que é necessário à república e que será para ti motivo de glória deliberei e expus o mais brevemente possível, 8. mas não seria ruim falar em meu próprio nome mais algumas palavras. 9. Muitos mortais possuem ou fingem possuir inteligência suficiente para julgar; no entanto é certo que, se para repreender palavras e ações alheias o espírito deles se inflame, parece difícil que a boca se abra ou a língua se disponha a expor o que se deliberou intimamente. Não me arrependo de modo algum em me sujeitar às suas críticas, pois mais me irritaria ficar calado. 10. Portanto, quer por este caminho, quer sigas por outro melhor, com minhas palavras e com minha ajuda fiz o que pude. Resta-me pedir que os deuses imortais aprovem e concedam sucesso àquilo que desejares. 


\section{Epístola II}

I. 1. Eu sei o quão difícil e grosseiro seja dar um conselho a um rei, a um imperador, ou a qualquer mortal, enfim, cujo poder chega ao máximo, não só porque ele poderia ter ao redor de si um séquito de conselheiros como também, em relação ao futuro, ninguém seja suficientemente hábil e prudente. 2. Além disso, ocorre frequentemente que os maus conselhos vinguem, em vez dos bons, porque a fortuna promove muitas coisas segundo sua própria vontade. 3. Mas desde jovem meu interesse foi zelar pela república, e fiz um grande esforço em conhecê-la não apenas para exercer a magistratura, que muitos alcançaram de maneira ilícita, e sim para que tivesse o conhecimento da república na paz e na guerra, e de quanto podia a opulência de armas e de homens. 4. Assim, depois de pensar muito, tomei a decisão de colocar minha fama e minha modéstia atrás de tua dignidade, e de correr todo o tipo de perigo, desde que disso resulte a tua glória. 5. Não decidi isso temerariamente ou em consequência de tua fortuna, mas porque averiguei em ti, particularmente, uma só admirável arte, além de outras: tua coragem é sempre maior na adversidade do que na sorte. 6. Contudo é mais evidente, a deduzir de outros mortais, que os homens antes se cansaram de louvar e admirar teus feitos, do que tu, de empreender feitos dignos de louvor.

II. 1. Na verdade, julguei que nada de tão sublime pode ser encontrado que já não esteja em teu pensamento, 2. nem te escrevi aqui meu parecer sobre a república porque valorizaria meu conselho e meu engenho mais do que o justo. Contudo, entre os trabalhos da milícia, entre batalhas, vitórias e o comando militar, decidi avisar-te dos assuntos urbanos. 3. Pois, se tens no peito a convicção de te vingares do ímpeto dos inimigos, ou também manténs os benefícios do povo à revelia do cônsul, teu adversário, pensas em coisas indignas de tua virtude. 4. Porém, se há em ti aquela disposição, que desde o princípio já dispersou a facção da nobreza, restituiu de uma cruel 
servidão a liberdade para a plebe romana, derrotou, inerme, as armas dos inimigos durante a pretura e promoveu tantas e tão importantes ações na paz e na guerra que nem mesmo os inimigos ousariam queixar-se senão de tua grandeza, aceita então aquilo que direi sobre o bem comum, que acharás verdadeiro ou decerto não distante da verdade.

III. 1. Uma vez que Cn. Pompeu, no entanto, ou por desatino ou por preferir algo que te obstruísse, assim se enganou, entregando as armas às mãos dos inimigos, deves restabelecer a mesma situação a partir da qual ele desconcertou a república. 2. Antes de tudo, ele restituiu a uns poucos senadores o sumo poder de administrar os impostos, os gastos públicos e as decisões judiciais, e por meio de leis iníquas lançou sem demora a plebe romana, que outrora possuía o máximo poder, à escravidão. 3. Mesmo entregues, como antigamente, às três ordens, rege a mesma facção aos assuntos judiciais, fazendo e desfazendo o que quer, perseguindo inocentes, elevando os seus às honras. 4. Não se impede um crime, uma infâmia, uma torpeza sem que eles tomem um cargo, o qual, se for vantajoso, roubam ou põem a perder. Por fim, como numa cidade capturada, eles se valem, no lugar das leis, de sua ganância e licenciosidade. 5. Mas eu de fato não me admiraria se eles, como de costume, transformassem em escravidão uma vitória alcançada com virtude. 6. Porém os homens mais covardes, dos quais toda a força e virtude estão situadas na língua, promovem, insolentes, uma dominação imposta pela ventura e fraqueza de outrem. 7. Afinal, que sedição e dissensão civil extinguiu tantas e tão ilustres famílias? Ou de quem o ânimo foi, mesmo na vitória, tão precipitado e tão imoderado?

IV. 1. L. Sula, que tudo pode fazer na vitória por meio da lei da guerra, ainda que compreendesse que suas facções eram munidas pelo suplício dos inimigos, contudo preferiu, depois de uns poucos assassinatos, impedir outros, tanto pelo benefício quanto pelo medo. 2. Mas, por Hércules, a comando de M. Catão, L. Domício e de outros da mesma facção, foram oferecidos como vítimas quarenta senadores, muitos, aliás, jovens promissores, enquanto a espécie mais perigosa de homens não pode se saciar do sangue de tantos míseros civis: nem os órfãos, nem os pais de idade avançada, nem a dor e o lamento de homens e mulheres venceu-lhes o ânimo cruel. 
Ademais, dizendo e fazendo o mal com crescente crueldade, quiseram privar uns de sua dignidade, outros dos direitos de cidadãos. 3. Então, o que dizer de ti, cujo agravo os homens mais ignaros querem provocar a custo da própria vida, se convier? Não possuem maior desejo de poder - embora esse lhes venha sem esperarem - do que inveja, em razão de tua dignidade. Além disso, é mais conveniente para eles colocar em risco a liberdade por meio da tua desgraça do que, por meio de ti, de grande tornar máximo o poderio do povo romano. 4. Por isto também deves prever como estabilizar e consolidar a situação. 5. Na verdade, aquilo que minha mente me apresenta eu não hesitarei em dizer. O resto cabe ao teu juízo aprovar: aquilo que julgues verdadeiro e útil a fazer.

V. 1. Em duas partes eu julgo que a cidade está dividida - de acordo com o que tive conhecimento dos antigos: em patrícios e plebe. Antigamente, aos patrícios pertencia o sumo poder, e à plebe uma força muito maior. 2. Foi assim que muitas e muitas vezes houve conflito na cidade, e sempre a força da nobreza foi diminuída e o direito do povo, ampliado. 3. Mas a plebe até ali vivia livremente, porque o poder de ninguém estava acima das leis, nem o nobre se antepunha ao ignóbil pelas riquezas ou soberba, mas pela boa fama de suas ações: o homem mais humilde não era privado, nas lavouras ou na milícia, de nenhuma coisa honesta - era o bastante para si e para a pátria. 4. Mas quando a inércia e a pobreza paulatinamente obrigaram-nos, expulsos dos campos, a ter morada incerta, eles começaram a reivindicar outros haveres e a tratar sua liberdade, e com ela a república, como algo venal. 5. Assim, paulatinamente, o povo, que era senhor e tinha mando sobre todos os povos, perdeu a união e, em vez de um poderio único, cada um criou para si, privadamente, a escravidão. 6. Por consequência essa multidão, primeiramente imbuída de maus hábitos e depois lançada a diferentes formas de atividade e de vida, de modo algum de acordo consigo, parece-me decerto pouco idônea para administrar a república. 7. Ademais, acrescidos de novos cidadãos, tomame uma grande esperança de haverem outros que despertem para a liberdade, visto que o apreço tanto nasce, aos patrícios, da liberdade mantida, quanto, à plebe, da servidão perdida. 8. Eu creio que deves estabelecer os novos misturados aos mais velhos nas colônias; assim também a força militar será mais poderosa e a plebe, ocupada com assuntos virtuosos, deixará de promover o mal 
coletivo.

VI. 1. Mas não ignoro nem estranho - quando tais coisas ocorrerem - quanta violência e quais tormentas entre os homens nobres se desencadearão; como, por misturarem-se inteiramente todas as coisas, indignar-se-ão; quando esta servidão for imposta aos antigos cidadãos e, por fim, um reino provir de uma cidade livre, onde pela ação de um só homem uma grande multidão alcançará a cidadania. 2. No entanto, tenho a convicção de que admite um grande crime aquele que obtém o reconhecimento por meio da desgraça da república; mas quando o bem público também é usado como privado, duvidar em atacar é, como realmente penso, preguiça e indolência. 3. M. Druso sempre se dedicou com grande empenho à causa dos nobres, como tribuno; não teve a intenção de fazer coisa alguma se, a princípio, não fossem eles os conselheiros. 4. Mas os homens sediciosos, aos quais o dolo e a malícia eram mais importantes do que a confiança, quando compreenderam que por um só homem foi dado a muitos mortais o maior dos benefícios, cada um deles, culpado de ter um espírito ruim e traiçoeiro, julgou M. Druso como a si mesmo. 5. Assim, com medo de que por tamanho reconhecimento pudesse ele sozinho resolver a situação, contra isso sabotaram não só os planos dele, mas também os seus próprios. 6. Por isso, deves procurar com muito cuidado, imperador, muita proteção e amigos fiéis.

VII. 1. Não é difícil para o homem perseverante derrotar o inimigo à sua frente: cabe aos bons não provocar nem evitar os perigos ocultos; 2. assim, quando os trouxeres à cidade, e assim ter verdadeiramente renovado a plebe, empenha maximamente o ânimo na tarefa de aumentar a concórdia entre os mais velhos e os novos, a fim de se cultivarem os bons costumes. 3. Mas terás alcançado um bem muito maior à pátria, aos cidadãos, a ti e aos filhos, enfim à humanidade inteira, se eliminares a ganância de dinheiro ou, até onde puderes, diminuí-la. Não há outra maneira de poder governar os assuntos íntimos ou a república, nem na paz ou na guerra; 4. porque, onde invade a ganância de riquezas, nem a disciplina, nem o trabalho nem o juízo têm poder o bastante - até que o ânimo, enfim, desista. 5. Já muitas vezes tive notícia de reis, cidades e nações que perderam grandes impérios por causa da opulência e cederam, indigentes, à ferocidade - o que não é coisa de 
se admirar; 6. porque, quando o bom vê o mau mais reconhecido e mais bem quisto por causa das riquezas, primeiro irrita-se e revolve muitos sentimentos no peito; mas quando a glória vence a honra um pouco mais a cada dia, e a opulência à virtude, o ânimo se afasta da verdade rumo à ganância. 7. De fato, a glória se alimenta do esforço: donde a tiveres suprimido, a virtude por si mesma é amarga e injuriosa. 8. Por fim, quando se possuem riquezas honestas, ali estão todos os bens básicos: a confiança, a probidade, o pudor, a castidade; 9. porque há um só árduo caminho para a virtude; para o dinheiro cada um tome o caminho que lhe é conveniente - ele é gerado por bons e por maus atos. 10. Portanto, a primeira coisa a fazer é acabares com o poder do dinheiro. Que nenhum indivíduo seja julgado maior ou menor na dignidade ou na honra por suas posses, nem se crie um pretor ou cônsul com base na opulência, e sim na dignidade. 11. Mas em relação à magistratura, o povo facilmente emite um juízo. É uma tirania os juízes serem nomeados por poucos, e desonesto serem escolhidos por sua riqueza. Por isso é conveniente que todos os da primeira classe julguem, mas em número maior do que os que julgam. 12. Nunca os ródios ou outras cidades se arrependeram de seus juízes, quando indistintamente o rico e o pobre, cada um recebendo o que a sorte oferece, decidem desde as maiores até as menores ações.

VIII. 1. Mas para a eleição dos magistrados e para mim, de fato, agrada muitíssimo a lei, que C. Graco promulgara como tribuno, para serem convocadas ao acaso as centúrias, dentre as cinco classes indistintas. 2. Assim equilibrar-se-ão a riqueza à dignidade e um terá pressa para se sobrepor ao outro em virtude. 3. Este é, penso eu, o grande remédio contra as riquezas, pois do mesmo modo tudo será louvável e conveniente de acordo com seu proveito. A maldade é levada a cabo devido aos proventos: quando a tiveres eliminado, ninguém será mau gratuitamente. 4. Além disso a avareza, fera selvagem, cruel, é intolerável: aonde vai, devasta fortalezas, campos, templos e casas, mistura o divino ao humano, e não a obstam nem os exércitos e nem as muralhas para que não entre com sua força; despoja de todos os mortais a fama, a castidade, os filhos, a pátria e os pais. 5. Na verdade, se suprimires o respeito ao dinheiro, facilmente se vencerá pelos bons hábitos a terrível força da avareza. 6. Todos, os justos e os iníquos, lembram-se de que as coisas sucedem assim mesmo; 
todavia, deves não moderadamente resolver-te com a facção da nobreza, de cujas ameaças, se fugires, deixarás vulnerável todo o resto. 7. Porque eles, se demonstrassem seu valor com a virtude, seriam mais êmulos dos bons do que invejosos; mas já que a desídia e a inércia, a insensibilidade e a preguiça os invade, eles fazem ruído, maldizem e julgam que a boa fama alheia é a sua infâmia.

IX. 1. Mas por que deveria lembrar tantas coisas como se falasse de anônimos? O valor e a coragem de M. Bibulo, ele os perdeu no consulado: grosseiro na língua, mais maldoso do que imaturo no pensamento. O que ousaria aquele a quem o consulado, o máximo poder, foi a maior infâmia? 2. Ou é grande a força de L. Domício, de quem não faltam torpeza e crime em nenhuma parte do corpo? A língua é caluniosa, as mãos são cruéis, os pés são rápidos - e as partes que não se podem honestamente nomear, são ainda mais desonestas. 3. Não desprezo, todavia, a mente experiente, eloquente e ágil de M. Catão, características essas adquiridas dos gregos; a virtude, a vigilância, a solicitude, todavia, não são nada para os gregos. Ainda assim crês que se pode manter um império com os preceitos daqueles que perderam por inércia a sua liberdade dentro de casa? 4. O restante da facção é composta dos nobres mais inertes, nos quais nada existe além de um bom nome, apenas um título. As adições - L. Postúmio e o M. Favônio, parecem-me como a carga inútil de um grande navio: é útil enquanto está a salvo; mas se aparece qualquer adversidade, é a primeira a se lançar fora, porque seu valor é mínimo.

X. 1. Uma vez que - assim me parece - já discorri o bastante sobre como renovar e corrigir a plebe, falarei sobre aquilo que, creio eu, deves fazer em relação ao senado. 2. Depois que amadureci na idade e no pensamento, não treinei muito o corpo com armas e cavalos, mas exercitei o ânimo nas letras: aquilo que por natureza era mais certo, obtive-o pelo esforço. 3. E assim nesta vida eu descobri muitas coisas lendo e ouvindo: todos os reinos - tanto cidades como nações mantiveram um grande império enquanto lhes valeram os conselhos sinceros: aonde quer que os corrompessem o favor, o medo e a voluptuosidade, vieram as forças diminuídas, depois o império tomado e, por fim, foi-lhes imposta a escravidão. 4. Por isso, na minha opinião, a qualquer pessoa que ocupe um lugar superior e mais ilustre do que outras em sua cidade, cabe-lhe ter cuidado pela 
república; 5. porque, quando outros mantêm a república a salvo, apenas a liberdade é preservada. Aqueles que, por meio da virtude, granjearam riquezas, glória, honra para si, mal começa a república a ser perturbada, multiplicadamente começam a ter o ânimo fatigado por causa das preocupações e dos esforços: ou defendem a glória, ou a liberdade, ou o patrimônio, apressam-se e se apresentam em todos os lugares. Quanto mais florescentes na sorte, tanto mais espinhosos nas adversidades, inquietando-se com mais desassossego. 6. Portanto, quando a plebe obedece ao senado, como a alma ao corpo, e segue-lhe as decisões, é conveniente que os senadores tenham competência para a deliberação; para o povo, a habilidade é inútil. 7. Assim os nossos antepassados, ao se ferirem nas guerras mais cruéis, e terem perdidos os cavalos, os soldados e o dinheiro, jamais se privaram, armados, de lutar pelo poderio romano. Nem a falta de erário, nem a força dos inimigos, nem a adversidade sujeitou-lhes a enorme coragem, pois o que conquistaram com virtude, deram o mesmo valor que à vida. 8. E os ganhos foram obtidos mais pelos conselhos honestos do que pelas boas batalhas. Já que a república era, na concepção deles, unificada, todos ocupavam-se dela, um só grupo armava-se contra os inimigos, cada um exercitava o corpo e a mente não para sua própria força, mas para a pátria. 9. Mas, ao contrário daquela época, atualmente os homens nobres, a cujas almas invadiram a preguiça e a ignomínia, alheios aos esforços de guerra dos inimigos e peritos em conspiração dentro de casa, governam todos os povos com a soberba.

XI. 1. Assim os senadores, cuja deliberação outrora estabilizava a república hesitante, oprimidos pelo capricho alheio, pendem, vacilantes, para lá e para cá, decidindo uma coisa numa hora, e depois outra; conforme a rivalidade ou favor daqueles que dominam, assim julgam o bem e o mal público. 2. Isso porque, se a liberdade tivesse sido a mesma para todos, ou o voto secreto, a república teria maior vigor, e a nobreza, menos poder. 3. Mas, porque é difícil compartilhar-se do mesmo prestígio - com aqueles dentre os maiores, a virtude abandonaria a glória compartilhada, a dignidade e a clientela; a outra multidão possui muitos mais novatos - deves libertar do medo os votos deles. Assim, em segredo, cada um terá em mais conta o seu poder que o de outrem. 4. A liberdade é desejável aos bons e aos maus, aos sábios e aos ignaros. Mas, na verdade, muitos a 
perdem por medo. Tolos são os mortais! Aquilo que num certame é duvidoso, o que quer que ocorra, eles aceitam-no, por inércia, como vencidos. 5. Portanto, julgo que o senado pode se fortalecer em dois pontos: se tiver aumentado o número de senadores e promover o voto secreto. O voto secreto servirá de pretexto para que eles se exponham com o ânimo mais livre; o número maior no total traz tanto mais segurança quanto mais utilidade, 6. já que a maior parte deles, nestes momentos tempestuosos, ou se enredam nos julgamentos públicos, ou nas questões individuais, ou nos assuntos dos amigos, e quase não se apresentaram nas deliberações da república. Não os dividiram mais suas ocupações do que o poder tirânico. Os homens nobres, seguidos pelos senadores, que consideram como o acréscimo de uma facção, qualquer coisa que conviesse aprovar, repreender, decretar conforme desejavam, fizeram. 7. Mas na verdade, quando for maior o número de senadores votando através das tabelas, seguramente eles renunciarão à sua soberba ao ter de obedecer aqueles mesmos sobre os quais outrora governavam.

XII. 1. Talvez, imperador, desejarias, depois de ler esta carta, saber o número de senadores que se deve instituir, e de que modo eles se distribuiriam nos muitos e diferentes ofícios, uma vez que, penso, as decisões devam ser tomadas por todos que pertencem à primeira classe - qual distribuição, que número deverá haver em cada categoria. 2. Descrever cuidadosamente tudo isso não seria difícil para mim, mas antes devo me esforçar para demonstrar todas as minhas ideias e assim provar que são verdadeiras. Se quiseres tomar este caminho, o resto estará pronto. 3. Desejo que meu conselho seja prudente e, sobretudo, útil, porque onde te acontecer algo promissor, daí virá minha boa fama. 4. Mas o que mais me persegue é o desejo de que salves a república de qualquer maneira e o quanto antes. 5. A liberdade é algo mais caro para mim do que a glória, e eu te peço e te aconselho, eminentíssimo imperador, que, vencida a gente gálica, não permitas que se dissolva pela decrepitude o império sumo e invicto do povo romano, nem que decline pela maior das imprudências. 6. Certamente, se isso ocorrer, tua consciência não terá tido paz em nenhum dia ou noite e então, atormentado pela insônia, furibundo e desvairado, serás levado à loucura. 7. Pois me consta que, de fato, a vida de todos os mortais é velada por um nume divino, e a ação boa ou a má 
de quem quer que seja não fica reservada ao desprezo, e sim bons e maus recebem sua paga da natureza. 8. E se por acaso ela tarda muito, a cada um, neste ínterim, o seu ânimo mostra, a partir da consciência, o que esperar.

XIII. 1. Porém, se a pátria e teus pais pudessem falar contigo, decerto isto te diriam: ó César, nós, os homens mais fortes na melhor cidade, escolhemos-te para orgulho e proteção nossa e terror para os inimigos. 2. O que obtivemos depois de muitos trabalhos e perigos, entregamo-lo junto com tua vida, quando nasceste: a maior pátria desta Terra, o lar e a família mais ilustres desta pátria, além de boas qualidades e de uma riqueza honesta, e por fim todas as vantagens da paz e os prêmios da guerra. 3. Por tais amplíssimos benefícios não te pedimos uma ação má, e sim que restituas a liberdade perdida. 4. Tendo concluído isso, sem dúvida alguma a fama da tua virtude vagará por todos os povos. 5. Com efeito nesta tempestade, mesmo tendo realizado grandes ações na paz e na guerra, tua fama é igual à de muitos homens corajosos. Se restituíres à cidade seu nome amplíssimo e seu maior império, já próximo do ocaso, quem terá sido mais ilustre, quem terá sido maior? 6. Como a situação da cidade, por moléstia ou por destino, está ruim, quem duvida de que a devastação, as guerras, as mortes se alastrarão por todo o mundo? Mas se tiveres a boa vontade de gratificar a pátria e teus pais, num tempo futuro, depois de a república ser restituída, granjearás uma glória maior do que a de todos os mortais, e tua morte será mais gloriosa do que a vida de qualquer um. 7. Pois algumas vezes a fortuna castiga os vivos; a inveja fá-lo com frequência; quando a existência tiver cedido à natureza, depois de calados os detratores, a própria virtude mais e mais se eleva.

8. Aquilo que me pareceu o mais útil a se fazer e que acreditei ser de tua utilidade, escrevi o mais brevemente que pude. De resto, peço aos deuses imortais que tuas ações, de qualquer modo que ajas, dêem bom resultado para ti e para a república. 


\section{Bibliografia}

\section{Fontes primárias}

AELIUS THÉON. Progymnasmata. Texte établi, traduit et commenté par Michel Patillon (français) et Giancarlo Bolognesi (arménian). Paris: Collection “Les Belles Lettres”, 1997.

ARISTÓTELES. HORÁCIO. LONGINO. A poética clássica; introdução de Roberto de Oliveira Brandão; tradução de Jaime Bruna. SP: Cultrix, 6. ed., 1995.

ARISTÓTELES. Poética; trad. Eudoro de Souza. SP: Ars Poetica, 1993, 2a. edição.

ARISTÓTELES. Retórica. Introdução de Manuel Alexandre Júnior. Tradução e notas de Manuel Alexandre Júnior, Paulo Farmhouse Alberto e Abel do Nascimento Pena. Portugal: Imprensa Nacional/Casa da Moeda.

ARISTÓTELE. Retórica. Introduzione di Franco Montanari. Testo critico, traduzione e note a cura di Marco Dorati. Milano: Arnoldo Mondadori Editore, 1996.

C. IULII VICTORIS. Ars rhetorica. In Rhetores Latini Minores emmendabat Carolus Halm. Lipsiae in aedibus B. G. Teubneri, 1863.

CAYO SALÚSTIO CRISPO. Guerra de Yugurta/Fragmentos de las Historias/Cartas a César sobre el gobierno de la república. Introducción, traducción y notas de Agustín Millares Carlo. Universidad Nacional Autónoma de México, 1998.

CÉSAR, C.J. Bellum Ciuile - A Guerra Civil. Tradução, Introdução e Notas de Antônio da Silveira Mendonça. SP: Estação Liberdade, 1999.

CICERO. Brutus; Orator; english translation by H. M. Hubbell and G.L. Hendrickson. Cambridge: Harvard University Press, 2001. 
CICERO. De Oficiis; with an english translation by Walter Miller. London and New York Routledge, 1990, vol. XXI.

CICERO. De Oratore; english translation by E.W. Sutton. Cambridge: Harvard University Press, 1988.

CICERO. De re publica (selections): edited by James E. G. Zetzel. UK and New York Cambrigde Greek and Latin Classics University Press, 1995.

CICERO. De Re Publica. De Legibus; trad. Clinton Walker Keyes. Cambridge: Harvard University Press, 1988.

CICERO. Dello Stato (De re publica); a cura di Anna Resta Barile. Bologna: Arnoldo Mondatori Editore, 1994.

CICERO. Discursos Cesarianos. Introd., Trad. e notas de José Miguel Baños Baños. Madrid: Alianza Editorial, 1991.

CICERO. Divisions de l'art oratoire; Topiques (Partitiones Oratoriae/Topica); texte établi et traduit par Henri Bornecque. Paris: Les Belles Lettres, 1924.

CICERO. On invention; Best kind of orator; Topics; english translation by H. M. Hubbell. Cambridge: Harvard University Press, 2006.

CICERO. Pro Sestio. In Vatinium; with an english translation by R. Gardiner. London and New York Routledge, 1984.

CICERO. Speech on behalf of Publius Sestius; translated with introduction and commentary by Robert A. Kaster. Oxford University Press, 2009.

CICERONE. Dei doveri. A cura di Dario Artelli. Oscar Mondadori, 2008 [1991].

DEMETRIUS. On style; English translation by Doreen C. Innes; based on W. Rhys Roberts. Cambridge: Harvard University Press, 2005.

DIÓN DE PRUSA. “De la realeza”. In Discursos I - IX. Introd., trad. y notas de Gaspar Morocho 
Gayo. Madrid: Gredos, 1988.

DIONÍSIO DE HALICARNASSO. Tratado da Imitação; editado por Raul Miguel Rosado Fernandes. Lisboa: Instituto Nacional de Investigação Científica/Centro de Estudos Clássicos das Universidades de Lisboa, 1986.

EUTROPIUS. Abrégé de l'histoire romaine. Traduction nouvelle avec introduction, notes, tables et index par Maurice Rat. Paris: Garnier Frères, 1934.

FLORUS. Epitome of roman history. With an english translation by Edward Seymour Forster. Londres: Harvard University Press, 1984.

FLORUS. Oeuvres. Texte établi et traduit par Paul Jal. Paris: Les Belles Lettres, 1967, 2 vols.

Greek and Latin letters - an anthology with translation. Michael Trapp [org.]. UK and New York Cambrigde Greek and Latin Classics University Press, 2003.

HERMOGÈNE. L’art rhétorique. Trad. Michel Patillon. France: L’age d’homme, 1997.

HERMÓGENES. Sobre las formas de estilo (Peri Ideon). Introd., trad. y notas de Consuelo Ruiz Montero. Madrid: Gredos, 1993.

Libanius's Progymnasmata. Model exercises in Greek Prose Composition and Rhetoric/translated with introductions and notes by Craig A. Gibson. Georgia: Society of Biblical Studies, 2008.

MENANDRO EL RÉTOR. Dos tratados de retórica epidíctica. Introd. de Fernando Gascó; trad. y notas de Manuel García García y Joaquín Gutiérrez Calderón. Madrid: Gredos, 1996.

PRISCIANO. Prisciani praeexercitamina. Grammatici Latini; ex recentione Henrici Keilii. Lipsiae: B G Tevbneri, 1857 - 192?, pp. 431-440.

Progymnasmata: Greek textbooks of prose composition and rhetoric/translated with introductions and notes by George A. Kennedy. Georgia: Society of Biblical Studies, 2003.

PSEUDO-SALLUSTE. Lettres a César. Invectives; texte établi, traduit et commenté par A. Ernout. Paris: Collection “Les Belles Lettres”, 1962. 
QUINILIANI, M. Fabii. Declamationes quae supersunt (recognouit breuique adnotatione critica instruxit Constantinus Ritter). Oxonii e Typographeo Clarendoniano, MCMLXV.

QUINTILIAN. The Orator's Education (Institutio Oratoriae) Books 1-2; with an english translation by Donald A. Russell. London and New York Routledge, 2001.

QUINTILIAN. The Orator's Education (Institutio Oratoriae) Books 3-5; with an english translation by Donald A. Russell. London and New York Routledge, 2001.

QUINTILIAN. The Orator's Education (Institutio Oratoriae) Books 6-8; with an english translation by Donald A. Russell. London and New York Routledge, 2001.

QUINTILIAN. The Orator's Education (Institutio Oratoriae) Books 9-10; with an english translation by Donald A. Russell. London and New York Routledge, 2001.

QUINTILIAN. The Orator's Education (Institutio Oratoriae) Books 11-12; with an english translation by Donald A. Russell. London and New York Routledge, 2001.

Quintilianus Declamationes recensivit C. Ritter. Stutgardiae in aedibus B. G. Teubneri, 1965.

QUINTILIANUS. Institutionis Oratoriae libri XII (recognouit breuique adnotatione critica instruxit M. Winterbotton) - tomus II. Oxonii e Typographeo Clarendoniano, MCMLXX.

QUINTILIEN. Institution Oratoire. Tome VI (Livres $X$ et XI). Texte établi et traduit par Jean Cousin. Paris: Les Belles Lettres, 1979.

Retórica a Herênio. Introd. e trad. Ana Paula Celestino e Adriana Seabra. SP: Hedra, 2005.

[Cornifici] Rhetorica ad C. Herennium. Introduzione, texto critico, commento a cura di Gulatiero Calboli. Bologna: Pàtron, 1993.

SALLUSTE. Catilina; Jugurtha; Fragments des Histoires. Texte établi et traduit par Alfred Ernout. Paris: Collection “Les Belles Lettres”, 1974 [1941].

SALLUSTE. La conjuration de Catilina. Texte établi et traduit par Alfred Ernout; introduction et notes par Martine Chassignet. Paris: Collection “Les Belles Lettres”, 1999. 
SALUSTIO, C. Epistulae ad Caesarem; texto crítico, tradução e comentários filológicos de Virgilio Paladini. Bolonha: Casa Editrice Prof. Riccardo Pàtron, 2a edição, 1968.

SALLUST; with an English translation by J. C. Rolfe. Harvard University Press, 2005 [1921] (Loeb Classical Library).

SENECA, Lucius Annaeus. “On Clemency”. In Moral Essays - vol. I; with an english translation by John W. Basore. London/Massachusets: Harvard University Press, 1985.

SENECA, Lucius Annaeus. Des bienfaits - texte établi et traduit par François Préchac. Paris: Société d'édition Les belles lettres, 1926-1927, 2 vol.

SENECA, Lucius Annaeus. Dialogues de ira; trad. A. Bourgery. Paris: Les Belles Lettres, 1951.

SENECA/SALUSTIO. Tratado sobre a Clemência (Intr., trad. e notas de Ingeborg Braren)/A Conjuração de Catilina (Intr., trad. e notas de A.S. Mendonça). Petrópolis: Vozes, 1990.

TACITO. Anais; prefácio de Breno Silveira e tradução de J. L. Freire de Carvalho. RJ: W. M. Jackson, 1964 (Col. Clássicos Jackson).

TACITO. Annales ab excessu diui Augusti libri (recognouit breuique adnotatione critica instruxit C. D. Fisher). Oxonii e Typographeo Clarendoniano, MCMLXXXVI, 19ª ed.

TACITO. Histoires - tome I; texte établi, traduit et commenté par Henri Goelzer. Paris: Collection “Les Belles Lettres”, 1921.

TACITO. Histoires - tome II; texte établi, traduit et commenté par Henri Goelzer. Paris: Collection “Les Belles Lettres”, 1951.

TÉON, HERMÓGENES \& AFTONIO. Ejercicios de retórica. Introd., trad. e notas de Maria Dolores Reche Martinez. Madri: Editorial Gredos, 1991.

TRANQVILLI, C. Svetoni. Opera vol. I De vita Caesarum. Recensivit Maximilianus Ihm. Stvtgardiae in aedibvs B. G. Tevbneri, MXCLXVII. 


\section{Fontes secundárias}

ALEXANDER, Liz Anne. “The best regimes of Aristotle's Politics”. In History of Political Thought, vol. XXI, issue 2, 2000, pp. 189-216.

AMBRÓSIO, Renato. De rationibus exordiendi - Função e elaboração dos exórdios de Cornélio Nepos e Salústio Crispo. SP, 2002. Dissertação (Mestrado em Letras). Faculdade de Filosofia, Letras e Ciências Humanas da Universidade de São Paulo.

ANTON, Beatriz. “La epistolografia romana: Cícero, Séneca y Plinio”. In Helmantica. Revista de Filologia Clásica y Hebrea n. ${ }^{\circ}$ XLVII. Universidad Pontificia de Salamanca, 1996, pp. 105-148.

BARBER, Kimberly Anne. Rhetoric in Cicero's Pro Balbo - an interpretation. London and New York Routledge, 2004.

BARTSCH, Shadi. Actors in the audience. Theatricality and doublespeak from Nero to Hadrian. Harvard University Press, 1994.

BECK, Hans \& Duplá, Antonio et alii. Consuls and Res Publica: holding high office in the Roman Republic. Cambridge University Press, 2011.

BÉRANGER, Jean. “Diagnostic du Principat: l'empereur romain, chef de parti”. In Revue des études latines, n. ${ }^{\circ}$ 37, 1959, pp. 151-170.

BLOOMER, W. Martin. “A preface to the history of declamation: whose speech? Whose history?” in HABINEK, Thomas \& SCHIESARO, Alessandro. The roman cultural revolution. Cambridge University Press, 1999.

BOESCHE, Roger. “The politics of pretence: Tacitus and the political theory of despotism”. In History of Political Thought, vol. VIII, issue 2, 1987, pp. 191-210.

BONNER, S. F. Roman Declamation in the late Republic and early Empire. University Press of Liverpool, 1949.

BRAREN, Ingeborg. “Por que Sêneca escreveu epístolas?” In Letras Clássicas São Paulo, n. 3. SP: SBEC, 1999, p. 39-43. 
CHIAPPETTA, Angélica. Ad animos faciendos: comoção, fé e ficção nas Partitiones oratoriae e no De officiis de Cícero. Tese (Doutorado). Faculdade de Filosofia, Letras e Ciências Humanas da Universidade de São Paulo, 1997.

CHIAPPETTA, Angélica. De como mover os ânimos e estabelecer a fé: o discurso ordenado nas Partitiones Oratoriae. Texto não publicado, s/d.

CHOUET, Marc. Les lettres de Salluste a César. Paris: Société d'édition “Les Belles Lettres”, 1950.

CLACKSON. James \& HORROCKS, Geoffrey. The Blackwell history of Latin language. Massachusets: Blackwell Publishing, 2008.

CLARK, Donald Lemen. Rhetoric in Greco-roman Education. Columbia University Press, 1957.

COSTRINO, Artur. “A lição dos declamadores: Sêneca, o rétor, e as suasórias”. SP, 2010. Dissertação (Mestrado em Letras Clássicas). Faculdade de Filosofia, Letras e Ciências Humanas da Universidade de São Paulo.

COTTON, Hannah M. "Mirificum genus commendationis: Cicero and the Latin Letter of Recommendation. In The American Journal of Phylology, vol. 106, n. ${ }^{3}$, 1985, pp. 328-334.

CRAIG, Christopher. Shifting Charge and Shifty Argument in Cicero's Speech for Sestius. In The orator in action and theory in Greece and Rome. Brill. Boston, 2001, pp. 111 - 122.

DAVIDSON, Jorge. “Direito e ideologia na República Romana tardia”. In Textos do Grupo de Trabalho de História Antiga. ANPUH, 1999, disponível no sítio www.estig.ipbeja.pt

DAVIDSON, Jorge. “De Cicerón a Apiano: los conceptos de orden y desorden en la sociedad romana (siglos I a.C. y II d.C.)”. In GALLEGO, Julián. Prácticas religiosas, regímenes discursivos y el poder político en el mundo grecorromano. Buenos Aires: Universidad de Buenos Aires, 2001, pp. 151-168.

DUPONT, Florence. Recitatio and the reorganization of the space of public discourse. In HABINEK, Thomas \& SCHIESARO, Alessandro. The roman cultural revolution. Cambridge 
University Press, 1999.

FAIRWEATHER, Janet. Seneca the elder. Cambridge University Press. 1981.

FANTHAM, Elaine. Imitation and Decline: Rhetorical Theory and Practice in the First Century after Christ. In Classical Philology, vol. 73, n. ${ }^{\circ}$ 2, Apr. 1978, pp. 102-116.

FORTENBAUGH, William W. \& MIRHADY, David C. Peripatetic rhetoric after Aristotle. New Jersey: Transaction Publishers, 1994.

GENTILI, Bruno \& CERRI, Giovanni. History and biography in ancient thought. Amsterdam: J. C. Gieben Publisher, 1988.

GIANOTTI, Gian Franco \& PENNACINI, Adriano. Società e comunicazione letteraria di Roma Antica. Volume terzo: storia e testi da Tiberio al V secolo d.C. Italia: Loescher Editore, 1988.

GOETTEMS, Miriam Barcellos. “Considerações preliminares sobre o jogo antitético da historiografia de Salústio”. In Clássica, suplemento 2. Sociedade Brasileira de Estudos Clássicos, 1993, pp. 117-123.

GRIMAL, Pierre. "Le bon roi de Philodème et la royauté de César". In Revue des études latines, n. ${ }^{\circ}$ 44, 1966, pp. 254-285.

GRIMAL, Pierre. "Les éléments philosophiques dans l'idée de monarchie à Rome à la fin de la république". In FLASHAR, Hellmut \& GIGON, Olof [org.] Aspects de la philosophie hellénistique - neuf exposés suivis de discussions. Genèvre: Fondation Hardt, 1985, tome XXXII.

GRIMAL, Pierre. The rhetoric of imitation: genre and poetic memory in Virgil and other latin poets. Ithaca and London: Cornell University Press.

GRUBE, G. M. A. A Greek critic: Demetrius On Style. Toronto: University of Toronto Press, 1961.

HÖLKESKAMP, Karl-J. Reconstructing the Roman Republic. An Ancient Political Culture and Modern Research. Princeton/Oxford University Press, 2010. 
INGLEBERT, Hervé [org.] Idéologies et valeurs civiques dans le Monde Romain. Nanterre: Éditions A. et J. Picard, 2002.

JOLY, Fábio Duarte [org.]. História e retórica. Ensaios sobre historiografia antiga. São Paulo: Alameda, 2007.

KIRBY, John T. The Rhetoric of Cicero's Pro Cluentio. Amsterdam: J. C. Gieben Publisher, 1990.

KIVUILA-KIAKU, José M. “Tacite et le “discours ideologique” sur le principat. Histoire et philosophie dans l’élaboration de la pensée politique de Tacite”. In Clássica: Revista Brasileira de Estudos Clássicos, vol. 15/16, n. ${ }^{\circ}$ 15/16 - 2002/2003. São Paulo, 2003, pp. 143-164.

KRAUS, Christina Shuttleworth Kraus [org.]. The limits of Historiography: genre and narrative in Ancient historical texts. Mnemosyne Biblioteca Classica Batava, 1999.

LACEY, W. K. \& WILSON, B. W. J. G. Res publica - Roman Politics and Society according to Cicero. UK: Bristol Classical Press, 1978.

LAUSBERG, Henrich. Manual de retórica literária; versión española de José Pérez Riesco. Madrid: Biblioteca Editorial Gredos, volume II, 1976 [1967].

LAUSBERG, Henrich. Manual de retórica literária; versión española de José Pérez Riesco. Madrid: Biblioteca Editorial Gredos, volume I, 1994.

LEPORE, Ettore. Il princeps ciceroniano e gli ideali politici della tarda republica. Napoli: Istituto italiano per gli studi storici, 1954.

LOBUR, John Alexander. Consensus, concordia and the Formation of Roman Imperial Ideology. London and New York Routledge, 2008.

MAGDELAIN, André. Auctoritas Principis. Paris: Collection “Les Belles Lettres”, 1947.

MAIA JÚNIOR, Juvino Alves. Platão e Aristóteles no De re publica de Cícero. São Paulo: 2002. Tese (Doutorado em Letras Clássicas). Faculdade de Filosofia, Letras e Ciências Humanas da Universidade de São Paulo. 
MAL-MAEDER, Danielle. La fiction des déclamations. Mnemosyne Biblioteca Classica Batava, 2007.

MALHERBE, Abraham J. Ancient epistolary theorists. EUA: The Society of Biblical Literature, 1988.

MARQUES, Juliana B. Tempo e Temporalidade na Histórias e nos Anais de Tácito. SP, 2002. Dissertação (Mestrado em História Econômica). Faculdade de Filosofia, Letras e Ciências Humanas da Universidade de São Paulo.

MELLOR, Ronald. The roman historians. London and New York Routledge, 1999.

MILLAR, Fergus. The Roman Republic in Political Thought. University Press of Ner England, 2002.

MILLAR, Fergus. The Roman Republic and the Augustan Revolution. The University of North Carolina Press, 2002 (b).

MOMIGLIANO, Arnaldo. “Tácito e a tradição taciteana”. In As raízes clássicas da historiografia moderna; trad. Maria Beatriz Borba Lorenzano. Bauru: EDUSC, 2004, pp. 157-187.

MOMIGLIANO, Arnaldo. Ensayos de historiografía antigua y moderna; trad. de Stella Mastrangelo. México: Fondo de Cultura Económica, 1993.

MORGAN, Teresa. Literate education in the Hellenistic and Roman worlds. Cambridge University Press, 1998.

MORSTEIN-MARX, Robert. Mass Oratory and Political Power in the Late Roman Republic. Cambridge, 2004.

MOURITSEN, Henrik. Plebs and Politics in late Roman Republic. Cambridge University Press, 2007.

MOUSOURAKIS, George. A Legal History of Rome. Routledge. Oxon, 2007.

NICOLET, Claude. “O cidadão e o político”. In GIARDINA, Andrea. O homem romano; trad. 
Maria Jorge Vilar de Figueiredo. Lisboa: Editorial Presença, 1989, pp. 21-48.

OMENA, Luciane Munhoz de. A centralização do poder nas obras De Clementia e Diui Claudi Apocolocyntosis, de Sêneca. Campinas: 2002. Dissertação (Mestrado em História Social). UNICAMP.

PERNOT, Laurent. La rhétorique de l'éloge dans le monde gréco-romain. Paris: Institute d’Études Augustiniennes, 1993, 2 vols.

ROLLER, Matthew B. Constructing autocracy: aristocrats and emperors in Julio-Claudian Rome. USA: Princeton University Press, 2001.

ROSA, Claudia Beltrão da; ARAÚJO, Sônia Regina de \& JOLY, Fábio Duarte [org.]. Intelectuais, poder e política na Roma Antiga. RJ: Nau/Faperj, 2010.

ROSA, Claudia Beltrão da. Das guerras servis às guerras civis. A conjuntura de fins da República Romana. Material produzido para o curso "Das guerras servis às guerras civis: a conjuntura de fins da República Romana”, durante o XXIII Simpósio Nacional de História - História: Guerra e Paz, promovido pela Associação Nacional de História, 2005. Monografia não publicada.

ROSA, Claudia Beltrão da. Relações políticas na República Romana tardia: um estudo de vocabulário. Estudo preliminar para tese. In Concordia ordinum: ética e política no De oficiis de Marco Tulio Cícero. RJ, 2002. Tese (Doutorado em História). PPGH/IFCH/Universidade Federal Fluminense.

ROWE, Christopher; SCHOFIELD, Malcolm et alii. The Cambridge History of Greek and Roman Political Thought. Cambridge University Press, 2005.

SANTOS, Gilson Charles dos. Entre os olhos e os ouvidos: a guerra civil entre César e Pompeu nas narrativas de Floro e Lucano. Dissertação (Mestrado). Faculdade de Filosofia, Letras e Ciências Humanas da Universidade de São Paulo, 2007.

SANTOS, Marcos Martinho dos. “A epístola como exemplo de texto escrito”. In Clássica São Paulo, v. 11/12, n. 11/12. São Paulo: SBEC, 1999, p. 233-246. 
SANTOS, Marcos Martinho dos. “Arte dialógica e epistolar segundo as Epístolas Morais a Lucílio”. In Letras Clássicas São Paulo, n. ${ }^{\circ}$ 3. SP: SBEC, 1999, p. 45-93.

SANTOS, Marcos Martinho dos. As epístolas de Horácio e a confecção de uma ars dictaminis: o opus. Dissertação (Mestrado). Faculdade de Filosofia, Letras e Ciências Humanas da Universidade de São Paulo, 1997.

SCATOLIN, Adriano. A invenção no Do orador de Cícero: um estudo à luz de Ad Familiares I, 9, 23. Tese (Doutorado). Faculdade de Filosofia, Letras e Ciências Humanas da Universidade de São Paulo, 2009.

SCHOFIELD, Malcolm. "Cicero's definition of Res Publica”. In Cicero the philosopher. Twelve Papers. Clarendon Press, Oxford, s/d.

SCHWARTZ, Pablo. “Declamación y oratoria bajo Augusto: a propósito de Casio Severo, Albucio Silo y Porcio Latrón”. In Letras Clássicas São Paulo, n. o 4. SP: SBEC, 2000, p. 273-293.

SEBASTIANI, Breno Battistin. Bélica lição polibiana. SP, 2006. Tese (Doutorado em História Social). Faculdade de Filosofia, Letras e Ciências Humanas da Universidade de São Paulo.

SHOTTER, David. The fall of Roman Republic. London: Routledge, 1994.

VASCONCELOS, Beatriz Avila. Ciência do Dizer Bem. A concepção de retórica de Quintiliano em Institutio Oratoria II, 11-21. São Paulo: Humanitas, 2005.

VELOSO, Cláudio William. Aristóteles mimético. São Paulo: Discurso Editorial, 2004.

VEYNE, Paul. L'Empire Gréco-Romain. Paris: Éditions du Seuil, 2005.

VICKERS, Brian. In defense of Rhetoric. Clarendon Press Oxford, s/d.

VIZENTIN, Marilena. Imagens do poder em Sêneca. Estudo sobre o De clementia. SP: Ateliê Editorial, 2005.

WEISHE, Alfons. Philosophie grecque et politique romaine dans la partie finale du "Pro Sestio”. In Bulletin de L'Association Guillaume Budé - tome xxix. Les Belles Lettres. Paris, 1970, pp. 483- 
488.

WEST, David \& WOODMAN, Tony [org.]. Creative Imitation and Latin Literature. Cambridge University Press, s/d.

WINTERBOTTOM, Michael. Quintilian and the Vir Bonus. In The Journal of Roman Studies, vol. 54, parts 1 and 2, 1964, pp. 90-97.

WIRSZUBSKI, Ch. Libertas as a Political Idea at Rome during the Late Republic and Early Principate. Cambridge University Press, 2004 [1950].

WOLFF, Francis. Aristóteles e a política. Trad. Lygia Araujo Watanabe. São Paulo : Discurso Editorial, 2001 (Coleção Clássicos \& Comentadores).

WORTHINGTON, Ian. Persuasion: greek rhetoric in action. London and New York Routledge, 1994.

ZOIDO, Juan Carlos Iglesias [org.]. Retórica e historiografia: el discurso militar en la Historiografia desde la Antigüedad hasta el Renacimiento. Madrid: Ediciones Clásicas, 2008. 